\title{
Abolishing the Crime of Public Nuisance and Modernising That of Public Indecency
}

\author{
Graham McBain ${ }^{1,2}$ \\ ${ }^{1}$ Peterhouse, Cambridge, UK \\ ${ }^{2}$ Harvard Law School, USA \\ Correspondence: Graham McBain, 21 Millmead Terrace, Guildford, Surrey GU2 4AT, UK. E-mail: \\ gsmcbain@aol.com
}

Received: November 20, 2016 Accepted: February 19, 2017 Online Published: March 7, 2017

doi:10.5539/ilr.v6n1p1

URL: https://doi.org/10.5539/ilr.v6n1p1

\section{INTRODUCTION}

Prior articles have asserted that English criminal law is very fragmented and that a considerable amount of the older law - especially the common law - is badly out of date. ${ }^{1}$ The purpose of this article is to consider the crime of public nuisance (also called common nuisance), a common law crime.

- The word 'nuisance' derives from the old french 'nuisance' or 'nusance' ${ }^{2}$ and the latin, nocumentum. ${ }^{3}$ The basic meaning of the word is that of 'annoyance'; ${ }^{4}$

- In medieval English, the word 'common' comes from the word 'commune' which, itself, derives from the latin 'communa' - being a commonality, a group of people, a corporation. ${ }^{5}$ In 1191 , the City of London (the 'City') became a commune. Thereafter, it is usual to find references with that term - such as common carrier, common highway, common council, common scold, common prostitute etc ${ }^{6}$

- The reference to 'common' designated things available to the general public as opposed to the individual. For example, the common carrier, common farrier and common innkeeper exercised a public employment and not just a private one. Today, the word 'public' tends to be used instead of the word 'common.'

\footnotetext{
${ }^{1}$ See generally, GS McBain, Our Criminal Law should only be 200 Years out of date - and it should be Consolidated. Review of European Studies (2014), vol 6, no 2, pp 1-35.

${ }^{2} \mathrm{R}$ Kelham, A Dictionary of the Norman or Old French Language (1843)(nuisement) 'nuisance, annoyance'. Also, (nuire, nuyre) 'hurt, injure.' N Bailey, An Universal Etymological English Dictionary(nuisance) 'something noxious or offensive.' Also (noyance) 'harm, nuisance.' J Cowell, The Interpreter (1st ed, 1607)(nusance)(nocumentum)'commeth of the French nuire i[d est] nocere.' It would seem clear from the Liber Albus (see $\mathrm{n}$ 64), that the words 'nuisance' and 'annoyance' were (legally) treated as synonyms in medieval times, with their variant spellings (anoesance, anoesaunce, anosaunce, anusance, anusaunce, nosance, nosaunce etc - see Munimenta, n 65, vol 3, p 292). CT Onions (ed), The Oxford Dictionary of English Etymology (OUP, 1966)(nuisance) ' injury, harm...injurious or obnoxious thing...source of annoyance...OF [Old French](now arch) nuisance hurt, f[rench]. nuis, stem of nuire injure: L[atin] nocere...'

${ }^{3}$ JR Spencer, Public Nuisance - A Critical Examination [1989] CLJ 55 at p 56 'The word 'nuisance' - spelt 'nusans' until the spelling was deliberately archaised in the eighteenth century - comes from the Norman-French word 'nuisance', which in turn comes from the dog-Latin nocumentum. The word originally meant no more than 'harm.' WO Russell, A Treatise on Crimes and Misdemeanors $\left(1^{\text {st }}\right.$ ed, 1819; last ed $\left(12^{\text {th }}\right.$ ed), 1964), last ed, vol 2, p 1387 'Nuisance (nocumentum), or annoyance, means anything which works hurt, inconvenience or damage.' ${ }^{4}$ Oxford English Dictionary ('OED')(nuisance) '1. Injury, hurt, harm, annoyance. 2. Anything injurious or obnoxious to the community or to the individual as a member of it (esp. as an owner or occupier of property), for which some legal remedy might be found.' $\mathrm{S}$ Johnson, $A$ Dictionary of the English Language ( $\left(1^{\text {st }}\right.$ ed, 1755)(nuisance) '1. Something noxious or offensive. 2. [in law] Something that incommodes the neighbourhood.'

${ }^{5}$ See GS McBain, Time to Abolish the Common Carrier [2005] JBL 545 at p 548. For various instances of the word 'common' see Stroud, Judicial Dictionary of Words and Phrases (Sweet \& Maxwell, 2000); Words and Phrases Legally Defined (Butterworths, 1988) and D Walker, The Oxford Companion to Law (Clarendon Press, 1980).

${ }^{6}$ e.g. Statute of Marlborough 1267 c 15 'It shall be lawful for no man from henceforth for any manner of cause, to take distress out of his fee, nor in the king's highway, nor the common street, but only to the king or his officers having special authority.' (italics supplied). See also Spencer, n 3, p 58 .
} 
From early times, a legal distinction was made between common (public) and private nuisance. ${ }^{7}$ The former is a crime, the latter not. Archbold, Criminal Pleading, Evidence and Practice (2016) states:

Public nuisance is an offence at common law. A person is guilty of a public nuisance (also known as common nuisance), who (a) does an act not warranted by law, or (b) omits to discharge a legal duty, if the effect of the act or omission is to endanger life, health, property or comfort of the public, or to obstruct the public in the exercise or enjoyment of rights common to all her Majesty's subjects. ${ }^{8}$

In a Report issued by the Law Commission (the 'LC') in 2015 - entitled Simplification of Criminal Law: Public Nuisance and Outraging Public Decency ${ }^{9}$ - the LC recommended that public nuisance and outraging public decency become statutory crimes. The purpose of this article - while not dis-agreeing that outraging public decency should become a statutory crime - is to argue that public nuisance should be abolished. Indeed, the reason why this common law offence has not been abolished earlier is that its history is very confused and many legal writers (and the courts) have based their analysis on Hawkins, A Treatise of Pleas of the Crown (1st ed, 1716-21) ${ }^{10}$ although his definition - and analysis - of the crime was very subjective and he did not investigate the earlier law in any detail. As to this:

- $\quad$ Public Nuisance - Created by Legal Writers. In early times, various specific nuisances were crimes. However, it is unclear whether there ever was a generic crime of 'common nuisance'. That is, no court or judge seems to have created it. Rather, it is likely that it was created by legal writers such as Hawkins (1716-21) ${ }^{11}$ who 'packaged' together various distinct criminal nuisances under the generic title of 'common nuisance' - something he also did with the crime of 'contempt of the sovereign' for example. ${ }^{12}$ Thus, the provenance of public nuisance is suspect. Not a common law crime. A common textbook crime;

- $\quad$ Few Common Law Nuisances. Even if public nuisance was a legitimate common law creation there seem to have been few instances of it in early times. What has often been overlooked in the analysis of this crime is that - from early times (from 1197 at least) - there were Assizes of Ale, Bread, Wine, Cloth, Buildings, the Pillory etc. They stipulated statutory nuisances, not common law ones (see 6). Also overlooked are Ordinances for the City originating from the time of Edward I (1272-1307) (see 11) which were, probably, based on even earlier legislation, now lost. These stipulated statutory nuisances. However, there is no evidence that writers such as Hawkins had much knowledge of (or interest in) early City law. ${ }^{13}$ Therefore, he overlooked this. As it is, it is asserted that most nuisances, pre-Hawkins, were statutory; ${ }^{14}$

- $\quad$ Hawkins' Packaging. Hawkins - in his description of 'common nuisance' in 1716 - included distinct common law crimes. Thus, he included crimes of: (a) a common innkeeper refusing to provide a traveller with board and lodging; and (b) managing a disorderly house (brothel) (see 17). However, these did not require proof of nuisance to the public as such (nor did the crime of selling, or offering for sale, unwholesome food). Hawkins also included: (c) houses where gaming was carried on; (d) theatres; and (e) houses which harboured thieves or prostitutes. These he did by way of their being analogous to maintaining a disorderly house. However, in any case, (c)-(e) were, soon, superceded by legislation. Also, other crimes asserted to be 'common nuisances' were gathered into the Metropolitan Police Act 1839 (the '1839 Act'). which covered the Metropolitan Police District (the 'MPD') and the Town Police Clauses Act 1847 (the '1847 Act') which covered urban districts (see 21). These Acts are still extant. ${ }^{15}$ Various legal works failed to sufficiently note this transition to legislation;

\footnotetext{
${ }^{7}$ Russell, n 3, vol 2, p 1387 'Nuisances are of two kinds: public or common nuisance, which materially affects the public, and is a substantial annoyance to all the Queen's subjects; and private nuisance which may be defined as anything which causes material discomfort and annoyance, to a man in the use for ordinary purposes of his house or property. Public or common nuisances, as they affect the whole community in general, and not merely an individual, form the subject of public remedies and do not give a cause for private suit; for it would be unreasonable to multiply suits by giving every man a separate remedy for what damnifies him in common only with the rest of the lieges [subjects].'

${ }^{8}$ Archbold, Criminal Pleading, Evidence and Practice (Thomson Reuters, 2016), para 31-40.

${ }^{9}$ Law Commission, no 358 ('LC 358').

${ }^{10} \mathrm{~W}$ Hawkins, A Treatise of Pleas of the Crown (1st ed, 1716-21; last ed 1824).

${ }^{11}$ Blackstone (in 1765-9, see n 47) and R Burn, The Justice of the Peace and Parish Officer (1st ed, 1755; last ed (30th ed), 1869) closely followed Hawkins and his categorisation, without checking whether it was an accurate, or useful, one.

${ }^{12}$ See 17.

${ }^{13}$ The City material was, principally, in latin or anglo-norman (law french). Further, until Victorian times, City officials were (generally) protective of it (as well as of the City charters and their contents). In the first edition of his work in 1716 - when considering common nuisances - Hawkins only made reference to writers such as Coke and Rolle (his Abridgment) as well as to recent caselaw.

${ }^{14}$ These include the (often cited) crimes of nightwalking, eavesdropping and, possibly, of being a common scold.

${ }^{15}$ See 21. The Act which covered the City of London (from which the 1839 and 1847 Acts developed), the City of London Police Act 1839 (including the section on minor crimes, s 35), has been repealed.
} 
- $\quad$ Subjective Definitions. Hawkins defined 'common nuisance' by, effectively, taking the rationale for making the act a crime (because it caused a nuisance to the public). ${ }^{16}$ Further, Hawkins definition was (very much) a personal (and wide) one. This subjectivity was followed by writers such as Russell (1817-1964) (who added in indecency, see 20) and Sir James Fitzjames Stephen (in 1883) (see 22).

The result of this confusion and obscurity was that public nuisance became a 'ragbag' of a crime in which legal writers: (a) failed to separate statutory - from common law - nuisances; (b) failed to distinguish public nuisance from other crimes - such as those in respect of: common innkeepers, managing a brothel, unlawful treatment of the dead or indecency - none of which required nuisance to members of the public to be proved. Thus, public nuisance became (and is) one of the most confused crimes in existence. In the case of the LC and their Report in 2015 , it was hampered by the fact that their remit ${ }^{17}$ was only to consider public nuisance and not related common law offences and legislative material. However, it is asserted that public nuisance should be abolished for the following (simple) reasons:

(a) Abolishing Related Crimes. Related crimes of : (i) an innkeeper refusing board and lodging; and (ii) managing a disorderly house (brothel), are unnecessary. They should be abolished. Further, statutory nuisances in the local 1839 and 1847 Acts (shorn of obsolete material) should be placed in general legislation;

(b) Unlawful Treatment of the Dead. Some acts which were categorised as public nuisances relate to the unlawful treatment of the dead, which requires no proof of nuisance. ${ }^{18}$ This area of the common law should be placed in legislation; ${ }^{19}$

(c) Outraging Public Indecency. Some acts which were categorised as public nuisances relate to the crime of outraging public decency, which requires no proof of nuisance. This common law crime should be placed in legislation.

If (a) -(c) are done, there is no need to retain an offence of public nuisance since all such acts are now covered by legislation. At least, to the extent of $95-8 \%$. And, in the few possible cases where not (see 33) - they comprise classic examples of anti-social acts. Thus, they should be placed in current legislation dealing with the same. In short, to create a statutory offence of public nuisance will be to duplicate crimes as well as cause the same confusion as occurred in earlier times with the common law crime of public nuisance - where there was great overlap between it and other common law crimes as well as with statutory public nuisances.

In conclusion, public nuisance should be abolished. The acts presently covered by it are now covered by legislation or by crimes such as unlawful treatment of the dead and outraging public decency - crimes which do not require proof of nuisance. Any remaining acts should be included in current anti-social legislation.

\section{SOURCE MATERIAL}

With regard to this article, the following primary texts have been considered:

- $\quad$ Anglo-Saxon Law. Reference is made to texts by Attenborough, Robertson and Thorpe ${ }^{20}$ which contain translations of laws (dooms) from king Aethelbert (c. 518-616) until the Norman Conquest of 1066. Reference is also made to O'Brien, which contains an alleged version of the laws of Edward the Confessor (1042-66), likely written in the 1140 's , $^{21}$

\footnotetext{
${ }^{16}$ See Coke, $\mathrm{n} 385$ who indicated that keeping a disorderly houses was punished because it was a common nuisance.

${ }^{17}$ LC 358 in 2015 was preceded by a Consultation Paper by the Law Commission in 2010, see Consultation Paper, Simplification of Criminal Law: Public Nuisance and Outraging Public Decency, no 193 ('LC 193').

${ }^{18}$ See Apps C \& D.

${ }^{19}$ See GS McBain, Modernising the Law on the Unlawful Treatment of Dead Bodies (2014) Journal of Politics and Law, vol 7, no 3, pp 8999.

${ }^{20}$ FL Attenborough, The Laws of the Earliest English Kings (NY, 1963); AJ Robertson, The Laws of the Kings of England from Edmund to Henry I (Cambridge UP, 1925)(the latter covers legislation from AD 942 up to the reign of Henry I (1100-35)) and B Thorpe (ed), Ancient Laws and Institutes of England (printed by the Commissioners on the Public Records, 1840). For another translation of the earliest law, that of Aethelbert (597-616 AD), see P Wormold, The First Code of English Law (Canterbury Commemoration Society, 2005). See also: (a) J Hudson, The Oxford History of the Laws of England (OUP, 2012); (b) F Pollock \& FW Maitland, The History of English Law (Cambridge UP, 1968) ('P \& M'); (c) JH Baker, An Introduction to English Legal History (Reed, ${ }^{\text {th }}$ ed, 2002); (d) FM Stenton, Anglo-Saxon England (OUP, $3^{\text {rd }}$ ed, 1971); (e) F Palgrave, History of the Anglo-Saxons (W Tegg \& Co, 1876).

${ }^{21}$ BR O'Brien, God's Peace and King's Peace. The Laws of Edward the Confessor (Univ. of Pennsylvania Press, 1999).
} 
- Medieval Texts. Reference is made to the Laws of Henry I (c. 1113) ${ }^{22}$ as well as to the first text on English law, by Glanvill (c. 1189). ${ }^{23}$ Also, to Bracton (c. 1240), ${ }^{24}$ Britton, (c. 1290), ${ }^{25}$ Fleta (c. 1290) ${ }^{26}$ and the Mirror of Justices (c. 1290); ${ }^{27}$

- Yearbooks, Selden Society Reports \& Book of Assizes. Reference is made to the Yearbooks (1268-1535), ${ }^{28}$ the Selden Society reports ${ }^{29}$ and to the Book of Assizes (Liber Assisarum)(being criminal cases in time of Edward III, $1327-77) ;^{30}$

- $\quad$ Abridgments. Reference is made to the abridgments of Statham (c.1490), ${ }^{31}$ Fitzherbert (c.1516) ${ }^{32}$ and Brooke $(1586){ }^{33}$ as well as to the later abridgments of Hughes $(1660-3),{ }^{34}$ Rolle $(1668),{ }^{35}$ Sheppard $(1675),{ }^{36}$ Nelson $(1725-6),{ }^{37}$ Viner $\left(1^{\text {st }}\right.$ ed, 1741-57), ${ }^{38}$ Bacon $\left(5^{\text {th }} \text { ed, } 1798\right)^{39}$ and Comyns (last ed, 1822). ${ }^{40}$

- $\quad \mathbf{1 6}^{\text {th }} \& \mathbf{1 7}^{\text {th }}$ Century Texts. Reference is made, in particular, to texts by Pulton (1609-23), ${ }^{41}$ Dalton (1618-1746), ${ }^{42}$ Coke $(1628-41)^{43}$ and Hale (published in 1736); ${ }^{44}$

- $\quad \mathbf{1 8}^{\text {th }}$ Century Texts. Reference is made to texts by Hawkins (1716-1824), ${ }^{45}$ Burn $(1755-1869)^{46}$ and Blackstone $(1765-9){ }^{4}$

- $\quad \mathbf{1 9}^{\text {th }}$ Century Texts. Reference is made to texts by East (1803), ${ }^{48}$ Russell (1819-1964), ${ }^{49}$ Archbold (1822 - date) ${ }^{50}$ Gabbett (1843), ${ }^{51}$ Harris (1881-1973) ${ }^{52}$ and Stephen $(1883)^{53}$ - including the latter's History of the Criminal Law of England (1883); ${ }^{54}$

\footnotetext{
${ }^{22}$ LJ Downer, Leges Henrici Primi (Oxford, 1972).

${ }^{23} \mathrm{R}$ Glanvill, The Treatise on the Laws and Customs of the Realm of England (c. 1189)(Nelson, 1965).

${ }^{24} \mathrm{H}$ Bracton (trans Thorne), On the Law and Customs of England c.1240 (Cambridge UP, 1968-76). Bracton is now online, see bracton.law.harvard.edu.

${ }^{25}$ FM Nichols (ed), Britton (John Byrne \& Co, 1901).

${ }^{26}$ Fleta, see Selden Society ('SS'), vols 72, $89 \& 99$.

${ }^{27}$ Mirror of Justices, SS, vol 7.

${ }^{28}$ The best edition is that of Maynard (Vulgate, 1678), reprinted by LBE. David Seipp (a professor at Boston university) has put translations of most of the 22,000 Yearbook cases online in the form of an Index. See www.bu.edu/law/faculty/scholarship/yearbooks.

${ }^{29}$ See selden.society.com. Also www.wshein.com/ which has put SS vols 1-99 online.

${ }^{30}$ See www.lawbookexchange.com/. The Liber was first published in 1516 (J Rastell).

${ }^{31} \mathrm{~N}$ Statham, Abridgment of the Law (Pynson, c.1490). See translation of MC Klingelsmith (Boston Book Co., 1915).

${ }^{32}$ A Fitzherbert, La Graunde Abridgment. The $3^{\text {rd }}$ ed (1577) is generally preferred and it is cited in this article. The $3^{\text {rd }}$ ed has been reprinted by the Law Book Exchange.

${ }^{33}$ R Brooke, La Graunde Abridgment (Tottell, 1586).

${ }^{34}$ W Hughes, Grand Abridgment of the Law (Henry Twyford et al, 1660-3). This has been reprinted by the Law Book Exchange.

${ }^{35} \mathrm{H}$ Rolle, Abridgment des plusieurs Cases et Resolutions del Common Ley (A Crooke et al, 1668). This has been reprinted by the Law Book Exchange.

${ }^{36} \mathrm{~W}$ Sheppard, Grand Abridgment of the Common and Statute Law of England (sold by George Sawbridge et al, 1675).

${ }^{37}$ W Nelson, Abridgment of the Common Law (E \& R Gosling, 1725-6). This has been reprinted.

${ }^{38}$ E Viner, A General Abridgment of the Law and Equity (GCJ \& J Robinson, $1^{\text {st }}$ ed, 1741-57, $2^{\text {nd }}$ ed 1791). This has been reprinted by the Law Book Exchange (there is also a $\mathrm{CD}$ with wordsearch).

${ }^{39}$ M Bacon, New Abridgment of the Law ( $1^{\text {st }}$ ed, 1736; $5^{\text {th }}$ ed (H Gwillim (ed), 1798; last ed ( $7^{\text {th }}$ ed), 1832).

${ }^{40} \mathrm{~J}$ Comyns, Digest of the Laws of England ( $1^{\text {sted, }} 1762-7$, last ed, 1822). See also J Lilly, Practical Register $\left(1^{\text {st }}\right.$ ed, $1719 ; 2^{\text {nd }}$ ed, with supplement, 1745).

${ }^{41}$ F Pulton, De Pace Regis et Regni (printed for the Companie of Stationers, 1609). The last edition $\left(4^{\text {th }} \mathrm{ed}\right)$ was in 1623 . The first edition has been reprinted by the Law Book Exchange.

${ }^{42}$ M Dalton, The Countrey Justice (Societie of Stationers, $1^{\text {st }} \mathrm{ed}, 1618 ; 2^{\text {nd }}$ ed, 1619; last ed, 1746). The first edition has been reprinted by the Law Book Exchange.

${ }^{43}$ E Coke, Institutes of the Laws of England (W Clarke \& Sons, London, last ed, 1824, which is cited).

${ }^{44}$ M Hale, The History of the Pleas of the Crown (printed for E \& R Nutt \& R Gosling, 1736). See also M Hale, Pleas of the Crown (London, 1685) ('Hale PC').

${ }^{45}$ See $\mathrm{n} 10$.

${ }^{46}$ See $\mathrm{n} 11$.

${ }^{47}$ W Blackstone, Commentaries on the Laws of England (Oxford, Clarendon Press, $1^{\text {st }}$ ed, 1765-9, Univ. of Chicago Press rep 1979).The final edition of Blackstone was, effectively, that of HJ Stephen, New Commentaries on the Laws of England (4 vols, 1841-5). The last edition of Stephen was the $21^{\text {st }}$ ed (1950).

${ }^{48}$ EH East, $A$ Treatise of the Pleas of the Crown (only ed, 1803).

${ }^{49}$ See $\mathrm{n} 3$.

${ }^{50}$ See $\mathrm{n} 8$. See also JF Archbold, A Summary of the law relative to Pleading and Evidence in Criminal Cases (1822, being the $1^{\text {st }}$ ed).
} 
- $\quad \mathbf{2 0}^{\text {th }}$ Century and later Texts. Reference is made to texts by Kenny (1902-66), ${ }^{55}$ Cross and Jones (1949), ${ }^{56}$ Smith and Hogan $(1965)^{57}$ and Williams (1961). ${ }^{58}$ Also, to Holdsworth, ${ }^{59}$ Halsbury, ${ }^{60}$ Blackstone's Criminal Practice (2016), ${ }^{61}$ Archbold, Magistrates Courts Criminal Procedure (2016) ${ }^{62}$ and to a plethora of modern texts on criminal law. ${ }^{63}$

There is also useful material on public nuisances continued in early material relating to the City, viz. the:

- Liber Albus (White Book) of the City of London (c. 1419); ${ }^{64}$

- Liber Custumarum (Book of Customs) and Liber Horn; ${ }^{65}$

- Calendar of Letterbooks of the City of London; ${ }^{66}$

- Calendar of Pleas and Memoranda Rolls of the City of London; ${ }^{67}$

- Calendar of Early Mayor's Court Rolls. ${ }^{68}$

The history of the crime of public nuisance is now considered.

\title{
3. ANGLO-SAXON TIMES $^{69}$
}

\section{(a) General}

\author{
${ }^{51}$ J Gabbett, Treatise on the Criminal Law (Dublin, 1843). \\ ${ }^{52}$ SF Harris, Principles of the Criminal Law (Stevens \& Haynes, 1st ed, 1881; last ed, 1973). \\ ${ }^{53} \mathrm{JF}$ Stephen, A Digest of the Criminal Law (Macmillan \& Co, $3^{\text {rd }}$ ed, 1883). See also JF Stephen, A General View of the Criminal Law \\ (Macmillan, 1863). \\ ${ }^{54}$ JF Stephen, A History of the Criminal Law of England (Macmillan \& Co, 1883). \\ ${ }^{55}$ CS Kenny, Outlines of Criminal Law (Cambridge UP, $1^{\text {st }}$ ed, 1902). See also JWC Turner, Kenny's Outlines of Criminal Law (19 ${ }^{\text {th }}$ ed, \\ 1966 , last ed). \\ ${ }^{56}$ R Cross \& PA Jones, An Introduction to Criminal Law (2 $\left.2^{\text {nd }} \mathrm{ed}, 1949\right)$. The $1^{\text {st }}$ ed was in 1948. \\ ${ }^{57}$ JC Smith \& B Hogan, Criminal Law (1st ed, 1965). \\ ${ }^{58}$ G Williams, The General Part (1961). \\ ${ }^{59}$ W Holdsworth, A History of English Law (Sweet \& Maxwell, 2009 rep). \\ ${ }^{60}$ Halsbury, Laws of England ( $5^{\text {th }}$ ed, with updates, unless otherwise stated). \\ ${ }^{61}$ Blackstone's Criminal Practice 2015 (eds. A Hooper \& D Ormerod)('Blackstone CP'). \\ ${ }^{62}$ Archbold, Magistrates Courts Criminal Procedure (2015)('Archbold Procedure').
}

${ }^{63}$ See, for example: (a) C McAlhone \& R Huxley-Binns, Criminal Law. The Fundamentals (3rd ed, 2013); (b) MJ Allen, Textbook on Criminal Law (12 ${ }^{\text {th }}$ ed, 2013); (c) A Ashworth \& J Horder, Principles of Criminal Law ( $7^{\text {th }}$ ed, 2013); (d) R Card et al, Criminal Law (20 ${ }^{\text {th }}$ ed, 2012); (e) CMV Clarkson \& HM Keating, Criminal Law, Text and Materials $\left(7^{\text {th }}\right.$ ed, 2010); (f) C Elliott \& F Quinn, Criminal Law (8 ed, 2010); (g) R Heaton, Criminal Law (2 $2^{\text {nd }}$ ed, 2006); (h) J Herring, Criminal Law ( $8^{\text {th }}$ ed, 2013); (i) M Jefferson, Criminal Law (9 $9^{\text {th }}$ ed, 2009); (j) Lacey, Wells \& Quick, Reconstructing Criminal Law. Text and Materials ( $\left.4^{\text {th }} \mathrm{ed}, 2010\right)$; (k) J Loveless, Complete Criminal Law. Text. Cases and Materials ( $3^{\text {rd }}$ ed, 2012); (1) N Padfield, Criminal Law ( $7^{\text {th }}$ ed, 2010); (m) A Reed \& B Fitzpatrick, Criminal Law (4 ${ }^{\text {th }}$ ed, 2009); (n) AP Simester, Simester \& Sullivan's Criminal Law: Theory and Doctrine (5 ${ }^{\text {th }}$ ed, 2013); (o) D Ormerod, Smith \& Hogan's Criminal Law (14 ${ }^{\text {th }}$ ed, 2015); (p) DJ Baker, Glanville Williams Textbook of Criminal Law (1 ${ }^{\text {st }}$ ed, 1978; $3^{\text {rd }}$ ed, 2012); (q) MJ Allen \& S Cooper, Elliott \& Woods' Cases and Materials on Criminal Law (11 ${ }^{\text {th }}$ ed, 2013); (r) M Molan, Cases and Materials on Criminal Law (4 ${ }^{\text {th }}$ ed, 2008); (s) J Martin \& T Storey, Unlocking Criminal Law ( $3^{\text {rd }}$ ed, 2010); (t) P Hungerford-Welch \& A Taylor, Sourcebook on Criminal Law (1997); (u) M Molan et al, Bloy \& Parry's Principles of Criminal Law (4 ${ }^{\text {th }}$ ed, 2000); (v) W Wilson, Criminal Law (4 ${ }^{\text {th }}$ ed, 2011).

${ }^{64}$ In 1419 , John Carpenter made a repertory (that is, a book of remembrances) of existing laws, observances, rights and franchises of the City which is generally referred to as the Liber Albus. This was translated by HT Riley in 1861, see HT Riley, Liber Albus: The White Book of the City of London (Griffin \& Co, 1861).

${ }^{65}$ The Liber Custumarum (compiled in the early part of the $14^{\text {th }}$ century) and the Liber Horn (also called the Liber Legum Regum Antiquorum) belonged to Andrew Horn, lawyer and City Chamberlain who died in 1328. For these texts, see HT Riley, Munimenta Gildhallae Londoniensis: Liber Albus, Liber Custumarum et Liber Horn (Longmans, 1860), pts 1 \& 2.

${ }^{66}$ The full title is: 'Calendar of Letter-Books preserved among the Archives of the Corporation of the City of London at the Guildhall' (printed by order of the Corporation under the Direction of the Library Committee). See Letterbooks A (1275-98), B (1275-1312), C (12911309), D (1309-14), E (1314-37), F (1337-52), G (1352-74), H (1375-99), I (1400-22), K (temp Henry VI (i.e. 1422-71)), L (Edward IV to Henry VII (i.e. 1461-1509)). See also British History online,www.british-history.ac.uk and GS McBain, Liberties and Customs of the City of London - Are there any Left? (2013) International Law Research, vol 2, no 1, pp 56-7. See also HT Riley, Memorials of London and London Life...AD 1276-1419 (Longman, 1868). Riley, a Victorian researcher, extracted material from the Letterbooks for his book.

${ }^{67}$ Calendar of Pleas and Memoranda Rolls preserved among the archives of the Corporation of the City of London at the Guildhall. vol 1 (1323-64), vol 2 (1364-81), vol 3 (1381-1412), vol 4 (1413-37), vol 5 (1437-57), vol 6 (1458-82).

${ }^{68} \mathrm{AH}$ Thomas, Calendar of the Early Mayor's Court Rolls preserved among the archives of the Corporation of the City of London at the Guildhall, AD 1298-1307 (Cambridge UP, 1924). See also RR Sharpe (ed), Calendar of Letters from the Mayor and Corporation of the City of London c. AD 1350-1370 enrolled and preserved among the archives of the Corporation at the Guildhall (London, 1885).

${ }^{69}$ See generally, n 20. 
It is thought that the main body of Roman troops and officials left Britain c. AD 410. Thereafter, Germanic tribes from Saxony ('Anglo-Saxons', also called 'Saxons' or 'Angles') migrated - in increasingly large numbers to Britain and they had probably subdued it during the years of Justinian's re-conquest of Italy (i.e. AD 534-54).

- When the Anglo-Saxons first arrived in England in the $5^{\text {th }}$ century, there was (likely) a great decline in the population (as in Europe) due to war and plague. ${ }^{70}$ This was exacerbated with the arrival of Danish armies (Vikings) from $\mathrm{AD} 8667^{71}$

- Indeed, much of the history of Anglo-Saxon England is characterized by war - both with external enemies and among the kingdoms. ${ }^{72}$ Thus - even by the time of the Norman Conquest 1066 - the population of England would (likely) have only been c. 2-3 million persons and widely scattered at that. ${ }^{73}$

\section{(b) Cities, Towns \& Villages}

A crime such as public nuisance arises when people are in close proximity - in cities, towns and villages. In Roman Britain, there were a number of cities and towns. ${ }^{74}$ However, it is generally thought that - after the departure of the main body of Romans in AD 410 - there was a decline in people living in cities and towns. In part, this may have been due to a decline in population from disease. It was also, likely, due to the increasing migration of Germanic tribes to England and its subjugation by c. AD 534 (see (a) above). These Germanic tribes preferred living in small settlements as opposed to towns. Referring to an earlier period, Tacitus (AD 56117) stated:

It is a well-known fact that the peoples of Germany never live in cities, and will not even have their houses set close together. They live apart, dotted here and there, where spring, plain or grove has taken their fancy. Their villages are not laid out in Roman style, with buildings adjacent or interlocked. Every man leaves an open space round his house, perhaps as a precaution against the risk of fire, perhaps because they are such inexpert builders... They have also the habit of hollowing out caves underground and heaping masses of refuse on the top. In these they can escape the winter's cold and store their produce. ${ }^{75}$

Likely, this also reflected the position in early Anglo-Saxon England. Thus, there was a gradual decline in urban living ${ }^{76}$ - something assisted by the disappearance of coinage in the period AD 435-630 (nearly 200 years). ${ }^{77}$

\footnotetext{
${ }^{70}$ This could have been by as much as 50\%, see GS McBain, Modernising the Law: Breaches of the Peace and Justices of the Peace (2015) Journal of Politics and Law, vol 8, no 3, p 166.

${ }^{71}$ From AD 866, Danish armies (Vikings) began to winter in England - as opposed to raiding periodically. They brought with them their Danelaw. Eventually, the Danes put an end to all English kingdoms, save for that of Wessex. See also McBain, n $70, \mathrm{p} 166$.

${ }^{72}$ See generally, Stenton, n 20 and D Whitelock et al, The Anglo-Saxon Chronicle (Eyre \& Spottiswoode, $2^{\text {nd }}$ ed, 1965)(chronology).

${ }^{73}$ RH Britnell, The Commercialisation of English Society 1000-1500 (Manchester UP, 1996), p 5 asserted that 'There were perhaps fewer than 3m people living in the 13,278 places recorded in Domesday Book.' Cf. CK Allen, The Queen 's Peace (Hamlyn Lecture, 1953), p 4, who thought that the population of England in 1087 was c. one and a half million people.

${ }^{74} \mathrm{~J}$ Wacher, The Towns of Roman Britain (2nd ed, revised in 1995), p 22 provided a map of England and Wales in which he listed: (a) Carlisle; (b) Aldborough; (c) York; (d) Lincoln; (e) Wroxeter; (f) Leicester; (g) Caistor-by-Norwich; (h) Carmnarthen; (i) Caerwent; (j) Gloucester; (k) Cirencester; (l) Verulamium (St Albans); (m) Colchester; (n) London; (o) Silchester; (p) Exeter; (q) Dorchester; (r) Winchester; (s) Chichester; (t) Canterbury. Of these London, Colchester, Lincoln, Gloucester and York were Coloniae and Canterbury, Chelmsford and Verulamium were the first Civitas Capitalis, later ones being Caistor-by-Norwich, Chichester, Silchester and Winchester. With the Flavian expansion [AD 69-96], Cirencester, Dorchester, Exeter, Leicester and Wroxeter were added and, under Hardian [AD 11738], there followed Caerwent, Carmarthen, Brough-on-Humber and Aldborough. Coloniae in the early Empire were used to describe towns inhabited either by Roman (or Latin) citizens who might be retired army veterans. Their constitution - based on that of Rome itself - was governed by a charter (lex coloniae). Civitatis capitalis were civilian towns in foreign districts, established by the Romans as administrative centres. See Ibid, ch 1 .

${ }^{75}$ Tacitus on Britain and Germany (Penguin, 1954), p 114.

${ }^{76} \mathrm{~J}$ Haslam, Early Medieval Towns in Britain c. 700 to 1140 (1985), p 7 'It is generally accepted that urban life in Roman times disappeared everywhere in the course of the fifth century. This process of disintegration was the result of a decline in the fourth century; as a consequence of the end of the military presence and the disappearance both of a stable coinage and of organised industrial production.'

${ }^{77} \mathrm{G}$ Davies, A History of Money (Univ. of Wales Press, 2002), pp 147-53, 253. After the departure of the Romans in AD 410, it seems that coins ceased being used as a medium of exchange from c.AD 435-630. Further, the re-introduction of coinage even after AD 630 was something of a false dawn since it was not until the Statute of Greatley AD 928 that England was sufficiently united for Anglo-Saxon law to stipulate a single national currency. As a result, cattle (and - to a lesser extent - sheep, pigs and horses) were treated as currency. See Davies, ch 4. This leads one to also suppose that exchange (barter) was, likely, more extensive than sale in Anglo-Saxon England. At least, prior to the late $7^{\text {th }}-8^{\text {th }}$ century.
} 
However, by c. AD 700, it seems, this decline started to reverse. ${ }^{78}$ Haslam stated, with regard to this re-growth of English towns:

it seems likely that Roman towns of all sizes provided centres for the organisation of such local and regional administration as the Saxon or British successors to the Roman order were able to maintain. In many instances they also survived as religious (i.e. Christian) centres. Since...the increasing number of urban or proto-urban places recognisable from about AD 700 were both administrative and ecclesiastical centres, these factors are of some importance. ${ }^{79}$

It may also be that some larger towns always retained a human presence from Roman times - such as Bath, Canterbury, Chichester, Cirencester, Dorchester, Gloucester, London and Winchester. ${ }^{80}$ However, this was probably intermittent since many of these places were (often) devastated by disease, fire or war. In the Saxon period, there also seem to have been a number of royal villages ${ }^{81}$ - as well as a number of port towns (with their port-reeve). ${ }^{82}$

- Finally, London - of any English town - is the one most likely to have retained a continuous, substantive, human presence from Roman times. The cleric, Bede (writing in AD 731), stated that London in AD 604 was a 'trading centre for many nations who visit it by land and sea, $;^{83}$

- However, London was sacked or destroyed by fire on many occasions - such as in AD 764, 798, 801, 851, 886 and $982 .{ }^{84}$ Indeed, it may have remained empty of population for considerable periods of time, such as in the period AD $851-86 .{ }^{85}$ That said, London may have had a population of 5,000 persons by the 7 th century with perhaps - 20 markets or so. ${ }^{86}$

In conclusion, from the latter part of the 7th century, there would have been some Anglo-Saxon towns with substantive populations, including London. Thus, the potential for crimes of nuisance - whether private or public - would have existed.

\section{(c) Anglo-Saxon Laws - Common Nuisance}

\footnotetext{
${ }^{78}$ Haslam, n 76, p 13 'During the seventh century the first glimmerings of the establishment of at least the basis of a new urban order can be discerned.' Cf. C Brooke \& G Keir, London 800-1216. The Shaping of a City (Univ. Of California Press, 1975), p 286 'In [AD] 900 or 1000 a tiny percentage of the population of England lived in towns...'.

${ }^{79}$ Ibid, p 9.

${ }^{80}$ Ibid, pp 9-10 'The continuation of many Roman towns as 'centres of authority' into later centuries is highly significant. The defences of some of these, such as Winchester and possibly London and Canterbury, were refurbished during this early period. The defeat of kings in Gloucester, Cirencester and Bath in [AD] 571 by incoming Saxons shows that each town was then the administrative centre of a small kingdom. Similarly, both London and Canterbury remained as central refuges for kingdoms or tribes in the fifth and sixth centuries; a royal palace certainly existed at London from the early seventh century, if not earlier. It seems likely that such places emerged as non-urban centres of royal authority by possibly continuous development from the Roman period.'

${ }^{81}$ Ibid, p 10 'the establishment of royal vills in the early or middle Saxon period as the centres of large estates or territories in close topographical relationship to former Roman towns.' Ibid, p 13 'The royal estate centres of the middle Saxon period were the instruments by which much of England was administered.

${ }^{82} \mathrm{Ibid}, \mathrm{p} 15^{\prime}$ the period from the early seventh century onwards saw the rise of a number of comparatively large trading settlements on coastal locations in southern and eastern England, which developed in response to the growth of trading activities involving northern Europe as a whole. These places, most of them on new sites, were often called -'wics' and included York (Eoforwiceastor), Norwich, Fordwich, Ipswich, London (Lundenwic), Sandwich and Southampton (Hamwic). They developed in parallel with other similar sites from Scandinavia to France...'.

${ }^{83}$ Bede, A History of the English Church and People (Penguin, 1968), p 104. See also J Haslam (ed), Anglo-Saxon Towns in Southern England (1984), ch 9 (Saxon London, by T Dyson \& J Schofield).

${ }^{84}$ London was sacked in AD 851 by the Vikings, see Anglo-Saxon Chronicle, n 72, p 34. It was burnt in AD 886 when king Alfred took it from the Vikings, Ibid, p 42. It was also devastated by fire in 1077 ('worse than ever it had been since it was founded.') and in 1087. Ibid, pp 159, 163. See also D Whitelock, English Historical Documents c. 500-1042 (1968), n 72, pp 242, 249, 250 (London was devastated by fire in $\mathrm{AD} 764,798$ \& 801). Haslam, n 83, p 285 'Between 457, when London served as a refuge for the fleeing British...and 604, when the Kentish king Ethelberht founded St Paul's cathedral, there is no historical evidence for the city of London, and even these two notices were compiled at much later dates. Material evidence of any kind is lacking for occupation [of London] beyond the mid-5th century, or before the late 6th and early 7th centuries, and no structures earlier than the 8th century have been found.' See also Brooke, n 78, p 21 (London burnt down in $\mathrm{AD}$ 982).

${ }^{85}$ After AD 457- when a Romano-British army was defeated by a Saxon army (commanded by Hengist) at the river Cray (some two miles west of Dartford) - London may not have been inhabited for some 50-80 years. Further, after the sack of London in AD 851, it is possible that it was barely inhabited until king Alfred re-took it in AD 886 (another 35 years). In AD 961, London experienced an outbreak of plague. ${ }^{86}$ Haslam, n 76, p 15 'Of these trading centres, London is perhaps the most fully documented from historical evidence. Probably from the early seventh century, if not rather earlier, it combined within its former Roman defences the functions of a royal and ecclesiastical centre on its western side and a commercial port and trading settlement on its eastern side. These functions were similarly combined at York.'
} 
Few Anglo-Saxon laws have come down to us ${ }^{87}$ and - as Pollock and Maitland pointed out - those which have, are likely to be mere 'superstructures on a much larger base of custom.' ${ }^{88}$ The earliest extant Anglo-Saxon law appears to be that of Aethelbert, king of Kent (AD 558-616) promulgated between AD 597-616. This code contains some 90 provisions - mainly relating to what we would term criminal law. ${ }^{89}$ It is also noteworthy that Anglo-Saxon law in the criminal sphere concentrated heavily on violent crimes (killing and battery) as well as on theft - especially of cattle. There is no mention of a crime of public nuisance. This is unsurprising due to, inter alia, the:

- $\quad$ relatively small population (see (a) and (b) above);

- tendency of the Anglo-Saxons to live in scattered settlements;

- laws of the Anglo-Saxons (as with their Germanic precursors) ${ }^{90}$ being specific and pre-emptory.

Therefore, there would have been little - or no - place for a generic crime of common nuisance. That said, if one looks ahead and considers what Hawkins (in 1716-21) in his legal text gathered together under the generic concept of 'common nuisance' (see 17) it is possible to identify various crimes in Anglo-Saxon law which may be said to comprise individual examples of public nuisance. Thus, the following may be noted:

- Disorderlv Houses - Brothels. This has been discussed in a previous article. ${ }^{91}$ The Roman Empire had brothels and licensed prostitutes. In Britain, the military encampment of Southwark (outside London) had brothels as did doubtless - other places. ${ }^{92}$ Contrariwise, the Germans were not licentious if Tacitus is correct (albeit this was prior to Anglo-Saxon times) ${ }^{93}$ and, in any case, Anglo-Saxon law was much influenced by Christianity and the church which sought to suppress adultery, fornication and prostitution. ${ }^{94}$ Thus, a decree of AD c. 906 (although this date is subject to dispute) ordered 'notorious' prostitutes to be driven from the land (that is, they were treated as akin to outlaws $) ;{ }^{95}$

- $\quad$ Disorderly Houses - Gaming etc. Hawkins (see 17) also referred to disorderly houses with regard to: (a) common stages for rope dancers (i.e. tightrope walkers, who were often linked to prostitution); (b) common gaming houses; (c) common playhouses; (d) a common innkeeper refusing board and lodging; (e) common houses harbouring thieves and prostitutes. As to the (likely) Anglo-Saxon position, none of these would have applied, since:

\footnotetext{
${ }^{87}$ Attenborough, n 20, cited: (a) the Kentish laws of Aethelberht (AD 558-616), Hlothhere and Eadric (AD 673-685/6), Eadric (AD 685-6) and Wihtred (AD 690/1-725); (b) the laws of Ine (AD 688-725) and of Alfred (AD 871-99); (c) a treaty of Alfred and the danish king Guthrum (AD c. 878-90) and the laws of Edward (the Elder, AD 899-924) and Guthrum (asserted, more recently, to have been written, c. AD 1000 by Wulfstan II, Archbishop of York (AD 1002-23);(d) the laws of Edward the Elder (AD 899-924) and of Aethelstan I (AD 92439). Robertson, n 20, cited: (a) laws of Edmund (AD 939-46) and Edgar (AD 943-75); (b) Promissio Regis (a coronation oath composed for Edward the Martyr (AD 975-8) or Aethelred II (AD 978-1016)); (c) the laws of Aethelred II (AD 978-1016)); (d) the laws of Canute (101635). Robertson also cited the 'laws' of William I (1066-87)(viz. a charter to the City of London, Regulations concerning exculpation, Episcopal laws, Ten Articles and Articuli Retractati) as well as various laws of Henry I (1100-35) (viz. a Coronation charter, a Decree concerning Coinage and a Decree concerning the county and hundred courts. Also, a charter to the City of London, c.1132-3).

${ }^{88} \mathrm{P} \& \mathrm{M}, \mathrm{n} 20$, vol 1, p 27.

${ }^{89}$ See generally, McBain, $\mathrm{n} 70$, especially, p 166. The state of England prior to Aethelbert's reign is described in MJ Whittock, The Origins of England 410-600 (Barnes \& Noble, 1986). Whittock, p 172, did not think that London began to revive as a commercial centre until the AD 640's.

${ }^{90}$ See GS McBain, Abolishing the Common Law Offence of Keeping a Disorderly House (2015) Journal of Politics and Law, vol 8, no 2, pp 17-53 (referring to various Germanic codes).

${ }^{91}$ Ibid.

${ }^{92}$ Ibid, p 22.

${ }^{93}$ Tactitus, $\mathrm{n} 75$, pp 115-6 'marriage in Germany is austere, and there is no feature in their morality that deserves higher praise. They are almost unique among barbarians in being satisfied with one wife each. The exceptions, which are exceedingly rare, are of men who receive offers of many wives because of their rank; there is no question of sexual passion...Thus it is that the German women live in chastity that is impregnable, uncorrupted by the temptations of public shows or the excitements of banquets. Clandestine love-letters are unknown to men and women alike. Adultery in that populous nation is rare in the extreme, and punishment is summary and left to the husband. He shaves off his wife's hair, strips her in the presence of kinsmen, thrusts her from the house and flogs her through the whole village. They have, in fact, no mercy on a woman who prostitutes her chastity. Neither beauty, youth nor wealth can find the sinner a husband. No one in Germany finds vice amusing, or calls it 'up-to-date' to debauch and be debauched. It is still better with those states in which only virgins marry, and the hopes and prayers of a wife are settled once and for all. They take one husband, like the one body or life that they possess. No thought or desire must stray beyond him. They must not love the husband so much as the married state... Good morality is more effective in Germany than good laws in some places that we know.'

${ }^{94}$ See McBain, n 90, p 22.

${ }^{95}$ Attenborough, n 20, p 109, Decree of Edward the Elder (AD 899-924) and king Guthrum (of Denmark) 'If...notorious prostitutes be met with anywhere in the country, they shall be driven from the land and the nation shall be purified'. Robertson, n 20, p 93, the Laws of Aethelred (AD 978-1016) made similar provision, 'if prostitutes...be met with anywhere in the land, they shall be zealously driven from this land and the nation shall be purified; otherwise they shall be utterly destroyed in the land, unless they cease from their wickedness and make amends to the utmost of their ability.'
} 
(i) Gaming. The Germans (like the Romans) saw no disgrace in gaming ${ }^{96}$ and there is no reason to believe this did not continue among the Anglo-Saxons;

(ii) Plavhouses. The Germans had a form of public entertainment ${ }^{97}$ - naked dancing - though this, probably, did not long continue among the Anglo-Saxons with their Christianization;

(iii) Common Innkeeper refusing Board \& Lodging. The Germans were very keen on banquets and entertaining ${ }^{98}$ - as well as on drinking bouts ${ }^{99}$ - and the Anglo-Saxons were the same. However, 'common inns' (i.e. public hotels) are thought to have only commenced with the monks in post-Conquest times. ${ }^{100}$ Thus, taverns, in Anglo-Saxon times (likely) were assembly places for communal drinking and feasting (in part) - as opposed to places where people could stay overnight, for payment;

(iv) Houses harbouring Thieves \& Prostitutes. Theft was severely punished (summarily, if a person was caught with the goods on them) ${ }^{101}$ and persons of 'ill fame' (such as reputed thieves, prostitutes, those suspected of crimes etc) were harshly treated - and, usually, outlawed. Thus, few would wish to shelter them. As a result, a distinct crime in respect of managing a house where such people congregated in Anglo-Saxon times would not have been required - not least since the law provided that a person was responsible for a guest who stayed longer than 3 days in his home. ${ }^{102}$

In conclusion, there was, probably, no need for a separate crime of maintaining a disorderly house in AngloSaxon times.

- $\quad$ Animals. Anglo-Saxon law made a person liable for: (a) damage done by an animal to another's premises ${ }^{103}$ (unless the other was, himself, the cause of it): ${ }^{104}$ (b) the intrusion of pigs into mast pasture (mast being the produce of trees which pigs ate); ${ }^{105}$ and (c) injury done by a dog ${ }^{106}$ or other animal; ${ }^{107}$

In conclusion, the Anglo-Saxons had laws relating to damage committed by animals - albeit 'nuisance' was not referred to as such;

\footnotetext{
${ }^{96}$ Tacitus, $\mathrm{n} 75, \mathrm{p} 120$ 'they go in for dicing, if you can believe it, in all seriousness and in their sober hours, and are so recklessly keen about winning or losing that, when everything else is gone, they stake their personal liberty on the last decisive throw. The loser goes into slavery without complaint; younger or stronger he may be, but he suffers himself to be bound. Such is their perverse persistence, or, to use their own word, their honour. Slaves of this sort are sold and passed on, so that the winner may be clear of the shame that even he feels in his victory.'

${ }^{97} \mathrm{Ibid}, \mathrm{p} 120$ 'They have only one form of public show, which is the same wherever they foregather. Naked youths, trained to the sport, dance among swords and spears that are levelled at them. Practice begets skill, and skill grace, but they are not professionals or paid. However adventurous the play, their own reward is the pleasure they give the spectators.'

${ }^{98}$ Ibid, pp 118-9 'No nation abandons itself more completely to banqueting and entertainment than the German. It is accounted a sin to turn away any man from your door. The host welcomes his guest with the best meal that his means allow. When supplies run out, the host takes on a fresh role; he directs and escorts his guest to a new hostelry. The two go on, uninvited, to the nearest house. It makes no difference; they are welcomed just as warmly. No distinction is ever made between acquaintance and stranger as far as the right to hospitality is concerned.'

${ }^{99}$ Ibid, p 119 'Drinking bouts, lasting a day and a night, are not considered in any way disgraceful. Such quarrels as inevitably arise over the cups are seldom settled by mere hard words, more often by blows and wounds.'

${ }^{100}$ See GS McBain, Abolishing the Strict Liability of Hotelkeepers [2006] JBL 705 at 708.

${ }^{101}$ P \& M, n 20, vol 2, pp 578-9.

${ }^{102}$ Attenborough, n 20, 21 (Laws of Hlothhere and Eadric, AD 673-685/6) 'If a man entertains a stranger (or trader or anyone else who has come over the border) for three days in his own home, and then supplies him with food from his own store, and [if] he [the stranger] then does harm to anyone, the man shall bring the other to justice, or make amends on his behalf.' Ibid, Laws of Canute (c. 1035), Robertson, $\mathrm{n}$ 20, p 189 'no one shall entertain any man for more than three days, unless he is committed to his charge by the man whom he has been serving.'

${ }^{103}$ Attenborough, n 20, pp 49-51 'If commoners have a common meadow or other - partible - land to fence, and some have fenced their portion and some have not, [and cattle get in] and eat up their common crops or their grass, then those who are responsible for the opening shall go and pay compensation for the damage which has been done to the others, who have enclosed their portion. They [the latter] shall demand from [the owners of] the cattle such amends as are fitting. If, however, any beast breaks hedges and wanders at large within, since its owner will not or cannot keep it under control, he who finds it on his cornland shall take it and kill it. The owner [of the beast] shall take its hide and flesh and suffer the loss of the remainder.'

${ }^{104}$ Ibid, p 49 'A commoner's premises shall be fenced both winter and summer. If they are not enclosed, and a beast belonging to his neighbour strays in through the opening he himself has left, he shall have no claim on that beast, [but] he shall drive it out and suffer the damage.'

${ }^{105}$ Ibid, p 53 'If anyone finds swine intruding in his mast pasture, he may take security to the value of 6 shillings.'

${ }^{106}$ Ibid, p 75 'If a dog tears or bites a man, 6 shillings shall be paid for the first offence. If its owner continues to keep it, 12 shillings shall be paid for the second offence, and 30 shillings for the third. If the dog disappears after committing any of these offences, this compensation must nevertheless be paid. If the dog commits more offences and he [its master] still keeps it, he may pay compensation for whatsoever wounds may be inflicted, according to the amount of the [injured man's] full wergeld.'

${ }^{107}$ Ibid, p 75 'If a beast injures a man, [its owner] must hand over the beast [to the injured man], or come to terms [with him].'
} 
- $\quad$ Highways. Hawkins (see 17) referred to the obstruction of the highway as a form of public nuisance. In respect of Anglo-Saxon times:

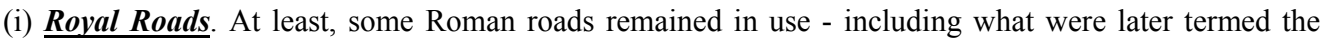
Royal highways on which the king's 'peace' (criminal jurisdiction) lay - namely Watling Street, Ermine Street, the Fosse Way and the Icknield Way. ${ }^{108}$ For example, there is reference to Watling Street in a peace treaty made c. AD 878-90 between king Alfred (AD 871-99) and the Danish king Guthrum. ${ }^{109}$ The asserted Laws of Edward the Confessor (1042-66) also referred to these four roads. ${ }^{110}$ Further, it is clear that Royal roads were important. Thus, to assault a person on a Royal road was a specific crime foresteal - the fine for which went to the sovereign. ${ }^{111}$ Was there a distinct crime to obstruct a Royal highway in Anglo-Saxon times? This is unclear. It may have been part of the crime of foresteal. By c. 1113 , however, there was a distinct crime - stretbreche - to obstruct a highway (street); ${ }^{12}$

(ii) Purprestures (Encroachments). Although Anglo-Saxon law did not distinguish between civil and criminal law, it is probable that 'purprestures' ${ }^{\prime 13}$ on these highways - as well as on roads in Royal vills would have been subject to a legal obligation to remove them and, likely, a fine - even though an obligation to maintain the highway was not part of the trinoda necessitas imposed on all citizens in Anglo-Saxon times. ${ }^{114}$ Thus, king Alfred (AD 871-99) - when seeking to defend Wessex against Viking attack - constructed many burghs (fortresses) and fortified towns. This involved the laying down of highways ${ }^{115}$ and these - such as in Winchester - were carefully planned. ${ }^{116}$ As a result, any obstruction of them would (likely) have been legally punished, since it would have impeded their military value.

- $\quad$ Bridges. Building, and maintaining, bridges was part of Anglo-Saxon military strategy from the 8th century. ${ }^{117}$ Further, the obligation of all citizens to maintain (but not build) bridges was one of the trinoda necessitas. ${ }^{118}$ Given

\footnotetext{
${ }^{108}$ Ibid, p 369 notes 'These are the OE [Old English] names applied to certain Roman or, in some cases perhaps, pre-Roman roads. The name Watling Street is applied to several such roads in different parts of the country. The chief of these, which is presumably meant here, is the one which runs through Wroxeter, Wall near Lichfield, Dunstable, London, and hence by Canterbury to the Kentish ports. Ermine Street is no doubt the Great North Road from London through Godmanchester and Lincoln and on into Yorkshire. The Fosse way ran through Lincoln, Leicester and Bath to Axminster. By the Icknield Way is probably meant a road of somewhat winding course, mainly pre-Roman, leading from East Anglia through Newmarket and Dunstable, across the Thames at Steathley and south-west into Dorset.'

${ }^{109} \mathrm{Ibid}, \mathrm{p}$ 99. As to the boundaries between the two kingdoms '[They shall run] up the Thames, and then up the Lea, and along the Lea to its source, then in a straight line to Bedford, and then up the Ouse to Watling Street.' (italics supplied)

${ }^{110} \mathrm{O}$ 'Brien, n 21, p 169. 'There are many types of the king's peace...another which the four roads have, that is Watling Street, Fosse Way, Iknield Way, and Ermine Street, of which two extend for the length of the kingdom, the others across the width...another held by the bodies of water on which victuals are brought by ship to cities and boroughs from various places.'

${ }^{111}$ Hudson, $n$ 20, p 50. Jurisdiction over this crime could be franchised, so that a lord of the manor could collect the fine. Obviously, he had to pay to get the franchise. Ibid, pp 58-9.

${ }^{112}$ See 4(b).

${ }^{113}$ Coke, n 43, vol 2, p 271 (Commentary on the Statute of Bigamy 1276) 'Purprestura comes of the French word purprise, or pourpris, which signifies an inclosure or building, and in legal understanding signifies an encroachment upon the king, either upon part of the king's demesne lands of his crown, which are accounted in law as res publicae, et semper favorabile suit in omni republica principis patrimonium; [public things, and the patrimony of the prince was always favourable in every Commonwealth] or in the highways, or in common rivers, or in the common streets of a city, or generally when any common nusans is done to the king and his people, endeavouring to make that private, which ought to be public.' OED, n 4 (purpresture) 'An illegal enclosure of or encroachment upon the land or property of another or (now only) of the public; as by an enclosure or building in royal, manorial, or common lands, or in the royal forests, an encroachment on a highway, public water-way etc.'

${ }^{114}$ This was the threefold obligation imposed on all subjects - to undertake military service when called on and to repair fortifications (castles) and bridges. See also $n 141$.

${ }^{115}$ Haslam, n 76, p 31 'Probably during the 880s king Alfred instituted a scheme for the defence of Wessex against Viking attack which involved the construction of a series of burhs at regularly spaced intervals from Kent to Devon. Many if not most of these were non-urban fortresses, though some were fortified towns whose large size and regular layout indicate that (as with the burghs of Offa [AD 757-96] a century earlier) their military effectiveness was to be maintained by a permanent population....At roughly the same period urban burhs were being founded by ealdorman Aethelred of Mercia at, for instance, Worcester, Gloucester .....and Hereford, a process involving the planned extension of earlier Roman and/or Mercian nuclei.'

${ }^{116}$ Ibid, pp 32-3 'At Winchester nearly 9 kilometres (5 1/2 miles) of streets were laid out to form a regular grid within the whole of the defended area. Similar grids of streets can be recognised in other boughs of this period such as Exeter, Cricklade, Wallingford, Chichester and London. The new streets at Winchester were initially metalled with some 8000 tonnes of flint cobbles...and flint beach pebbles were used to surface at least some of the new streets in London, operations which exemplify the sophisticated social arrangements required to construct the burgh system as a whole.' Also, p 37 'the 'restoration' of the city [of London] by Alfred in 886 resulted in the apportionment of blocks of land, bounded by streets, to individual lords.'

${ }^{117} \mathrm{Ibid}, \mathrm{p} 38$ 'There is a considerable amount of evidence for the hypothesis that between the years 899 and 911 Edward [the Elder, AD 899 924] was responsible for an entirely new defensive strategy for southern England. This appears to have involved the creation of a number of small urban burhs on distinctive topographical sites near river mouths or at estuary heads; these were linked with bridges, both bridge and burgh forming a single military unit designed to block rivers against penetration by Viking warships. It can be suggested that this scheme replaced the skeletal and probably incomplete system of fortress burhs initiated by his father Alfred. The policy of Edward's of constructing
} 
this, it would seem likely that those who obstructed bridges (or failed to maintain them) would be prosecuted in some way - likely, by the imposition of an fine as well as an order to remedy the same, ${ }^{119}$

- Common Scold, Eavesdropper, Nightwalker. Hawkins (see 17) mentions these as examples of public nuisance. As to the first, the word 'scold ' probably derives from the Norse 'scald' - one who made (insulting) poems. ${ }^{120}$ Under Anglo-Saxon law there was a 'crime' of insulting another by calling him a perjurer ${ }^{121}$ However, this seems to have been specific to perjury. There was another crime - slandering another in public. ${ }^{122}$ This could be source of the concept of the common (public) 'scold". As for the crimes of eavesdropping (one who spread false rumours) and nightwalking (one who broke curfew), these appear to be post-Conquest and associated with the City;

- Damaging Property. Anglo-Saxon houses were set within their own enclosure (at least, in early times) and there were Anglo-Saxon crimes connected with entering (or breaking into) such an enclosure ${ }^{123}$ as well as for damaging it. ${ }^{124}$ There was also a crime in respect of damaging crops. ${ }^{125}$ These comprised (in effect) private trespass for which a fine was payable - unless violence was involved, which was the crime of hamsocn - an attack on (or forcible entry into) a man's house.

There may also have been other forms of nuisance under Anglo-Saxon law. The so-called Laws of Edward the Confessor (redacted c. 1140's) - as well as treating the four principal Roman roads as Royal roads ${ }^{126}$ - indicate that the Crown in Anglo-Saxon times was asserting jurisdiction over other highways and as well as waterways and (possibly) the sea. Thus, the Laws state:

if mills, fisheries [probably a reference to weirs] or any other structures are set up to block them [the king's roads and waterways], those structures shall be destroyed [and] the roads and waterways shall be restored, and the monetary penalty is the king's.

Other roads from city to cities, from boroughs to boroughs, on which people travel to markets or for their other business affairs, are under the law of the county. And if any structure is erected to block them, it shall be pulled down, and the roads shall be repaired, and he shall make amends to the earl and sheriff following the law of the county. Similarly, concerning lesser waterways used by ships bearing necessities such as lumber and other things to cities and boroughs: they and their compensation are the same as in the law of the lesser roads.

The boundaries of the king's shires properly belong with the judgment of the four royal roads. The boundaries of the hundreds, of the wapentakes, [belong] to the earls and the sheriffs with the judgment of the county. ${ }^{127}$

burgh-bridge units to command river access seems to have mirrored that initiated by Offa [AD 757-96] in Mercia in the late eighth century and is a strategy which also finds many parallels on the continent.'

${ }^{118}$ See $\mathrm{n} 114$.

${ }^{119}$ Laws of Athelred (AD 978-1016), see Robertson, n 20, p 87 'the repairing of fortresses and of bridges throughout the country on every side, and also the duties of military service shall always be diligently attended to, whenever the need arises, in accordance with the orders given.' Ibid, p 101. See also Laws of Canute (c. 1035). Ibid, p 179.

${ }^{120}$ Punishment may have been the ducking (cucking) stool which may have derived from the Saxon 'scealsing stol' (diving stool). See also J Ritson, The Jurisdiction of the Court Leet (2nd ed, 1809), p xii.

${ }^{121}$ Laws of Hlothhere and Eadric (AD 673-685/6), see Attenborough, n 20, p 20 'If one man calls another perjurer [manswara] in a third man's house, or accosts him abusively with insulting words [bismaerwordum scandlice], he shall pay one shilling to him who owns the house, 6 shillings to him he has accosted, and 12 shillings to the king.'

${ }^{122}$ Laws of Alfred (AD 871-99), see Attenborough, n 20, p 77 'If anyone utters a public slander, and it is proved against him, he shall make amends on no lighter terms than the excision of his tongue, [with the provision that] it shall not be ransomed at a cheaper price than [its value] estimated according to the man's wergeld.'

${ }^{123}$ Laws of Aethelbehrt (AD 558-616), see Attenborough, $\mathrm{n} 20, \mathrm{p} 9$ 'If a freeman breaks the fence around [another man's] enclosure, he shall pay 6 shillings compensation [likely, the sum was fixed the same as that of a violation of protection between freemen]. If any property be seised therein, the man shall pay a threefold compensation. If a freeman makes his way into a fenced enclosure [presumably, this refers to ordinary trespass], he shall pay four shillings compensation....'.

${ }^{124}$ Ibid, p 9 'If anyone damages the enclosure of a dwelling, he shall pay according to its value.'

${ }^{125}$ Ibid, pp 49-51 'If commoners have a common meadow or other - partible - land to fence, and some have fenced their portion and some have not, [and cattle get in] and eat up their common crops or their grass, then those who are responsible for the opening shall go and pay compensation for the damage which has been done to the others, who have enclosed their portion. They [the latter] shall demand from [the owners of] the cattle such amends as are fitting. If, however, any beast breaks hedges and wanders at large within, since its owner will not or cannot keep it under control, he who finds it on his cornland shall take it and kill it. The owner [of the beast] shall take its hide and flesh and suffer the loss of the remainder.'

${ }^{126}$ See $\mathrm{n} 110$.

${ }^{127}$ O'Brien, n 21, pp 171-3. See also p 271 where he points out that the boundaries of shires were determined by the king while those of hundreds and wapentakes were determined by the earls and sheriffs. See also Ibid, p 58 (steward (dapifer) of the bishop of Lincoln amerced in 1130 for building a causeway on the king's road in Lincolnshire). 
It is noteworthy that a distinction was drawn by this early date between Royal roads (and waterways) and other 'public' roads (and waterways) - the latter comprising roads from 'city to cities, from boroughs to boroughs, on which people travel to markets or for their other business affairs'. Thus, the concept of the common or 'public' highway developed early.

\section{In conclusion, it seems likely that - in Anglo-Saxon times - obstructions (or damage) to highways, bridges or waterways: (i) under the king's jurisdiction; or (ii) classed as public; resulted in a liability to pay a fine as well as to restore (or remove the obstruction).}

\section{(d) Sheriff's Tourn \& Courts Leet}

Evidence of nuisances in Anglo-Saxon times would be helped by the existence of the sheriff's tourn and the court leet since these courts had jurisdiction over minor crimes, including public nuisances. Did these courts exist in Anglo-Saxon times ? Coke considered courts leet to be Anglo-Saxon ${ }^{128}$ and that they were instituted for the 'conservation of the king's peace, and punishment of common nuisances etc. ${ }^{129}$ For their part, Pollock and Maitland referred to the sheriff's court:

Twice a year the sheriff makes a tour or turn (turnus vice-comitis) through all the hundreds of the county. He holds each of the hundred courts...the townships also have to be represented at the sheriff's turn, each by its reeve and four of its men; for another object of the turn is that the sheriff may hold what we may call a 'police court' ...The presentments of minor offences are disposed of on the spot...In his 'turn' the sheriff acts as a judge with powers delegated from the king...'130

Pollock and Maitland also referred to the court leet. ${ }^{131}$ However, they did so - in the case of both courts - with reference to post-Conquest times. In the case of Anglo-Saxon times, they noted that the Anglo-Saxon courts of public justice were the: (a) county court: and (b) the hundred court. Further, they stated that the:

hundred court was the judicial unit, so to speak, for ordinary affairs. We have no evidence that any lesser public court existed. ${ }^{132}$

For his part, Hudson was uncertain as to the existence of either the tourn - or the court leet - in Anglo-Saxon England ${ }^{133}$ while Hearnshaw - who wrote a well received text on Leet Jurisdiction in England (in 1908) - as well as others, thought they did exist. ${ }^{134}$ Indeed - in purely practical terms - it is difficult to believe, in the case of the court leet, that a lesser court to the hundred court did not exist. After all, the population was widely

${ }^{128}$ Coke, n 43, vol 2, p 69 and vol 4, pp 261-5. As to the tourn, see vol 4, p 259 'The tourn...the ancient institution....was before Magna Carta [1215] to hear and determine all felonies (death of man excepted) and common nuisances.'

${ }^{129}$ Ibid, vol 4, p 263. This included punishment of those who sold adulterated, or unfit, foodstuffs. Ibid, p 261.

${ }^{130}$ P \& M, n 20, vol 1, p 530

${ }^{131}$ Ibid, pp 531-2 'Contrasted with the jurisdictional powers which a lord has merely because he is a lord with tenants, stand the franchises, liberties, royalties (libertates, regalia), powers and immunities which can only be possessed by those to whom the king has granted them. These franchises were of the most various orders, ranging from the powers of the palatine earl to those of the lord of a petty manor who had merely a view of frankpledge and the police jurisdiction that was incident to it. This last franchise was common, and the court in which the lord exercised it twice a year was acquiring the name of a leet (leta); it was a police court for the presentment of offences and for the punishment of minor offences; it was co-ordinate with the sheriff's turn.' Ibid, p 580 'Towards the end of the thirteenth century the word leet (leta) - which seems to have spread outwards from the East Anglian counties - was becoming a common name for such a court, but to the last visus franciplegii remained the most formal and correct of titles. The lord who had this franchise claimed to swear in a body of jurors often they were the chief pledges or heads of the tithings - and to put before them those same 'articles of the view' (capitula visus) which the sheriff employed in his 'turn'. The minor offences were punished on the spot by amercements which went to swell the lord's revenue.' Ibid, $\mathrm{p}$ 592.

${ }^{132}$ P \& M, n 20, vol 1, p 42. As for the wardmote court in London, see 6(d). See also Spencer, n 3, p 59.

${ }^{133}$ Hudson, n 20, pp 53 (tourn), pp 58-63 (franchisal courts). Cf. p 283 'It is also possible that in areas of the Danelaw sub-units of wapentakes [hundreds], sometimes referred to as 'small hundreds', had courts. Similar to these may have been the courts of East Anglian sub-hundredal units known as leets.' See also J Campbell, Hundreds and Leets: A Survey with Suggestions in Medieval East Anglia, ed C Harper-Bill (2005), pp 89-93, 244-5.

${ }^{134}$ FJC Hearnshaw, Leet Jurisdiction in England especially as illustrated by the records of The Court Leet of Southampton (1908). See also Ritson, n 120, pp vii, 8-9 and Bullen v Godfrey (1614) 1 Rolle Rep 73 (81 ER 337). Also, YB 7 Hen 6 pl 17 12b-13a, Seipp no 1428.017, per Cottesmore Sjt 'the leet is the oldest court in the land.' See also WP Baildon (ed), J Hawarde, Les Reportes del Cases in Camera Stellata 1593 to 1609 (rep Lawbook Exchange 2008), p 350 (Exchequer Chamber, 1608). Also, Mirror, n 27, p 9. See also R Powell, A Treatise of the Antiquity, Authority, Uses and Jurisdiction of the Ancient Courts of Leet or View of Frankpledge (1668), pp 13-4. Also, W Greenwood, The Authority, Jurisdiction and Method of Keeping County Courts, Courts Leet and Courts Baron (9th ed, 1730), p 174 'King Alfred, in the year 872, was the first institutor of this court which we now treat of, then called sciregemot, that is to say the Assembly of the Shire, and sometimes called the Sheriff's Moot.' 
scattered and resolving minor nuisances at the village (or hamlet) level would have been more efficient and sensible than reserving such matters to the weightier hundred court.

\section{(e) Conclusion}

Anglo-Saxon law did not distinguish between criminal and civil law. Nor between public and private nuisances. Nor did it have the concept of nuisance as such. Such 'public' nuisances as there were in Anglo-Saxon law were statutory and only appear to comprise the following:

- $\quad$ prostitutes were driven out or otherwise suppressed;

- obstructions on Royal (or public) highways, waterways and bridges incurred a fine - as well as restoration.

\section{In conclusion, there is no evidence, in Anglo-Saxon times, of a generic crime of public nuisance.}

\section{THE PERIOD $1066-1189$}

\section{(a) Laws of William I (1066-87)}

From the scant law (and sources available) in this period, there seems to be no evidence of a crime of public nuisance. None is mentioned in the (asserted) Laws of William I (c. 1090-1135) nor other laws said to have been passed in his reign. ${ }^{135}$

- It may also be noted that - when William approached London in December 1066 after the battle of Hastings - he laid waste to Southwark. Thus, he likely destroyed any brothels there - even if they had continued to exist after Roman times and they had not been suppressed in the Anglo-Saxon age, ${ }^{136}$

- Despite considerable urban developments in Anglo-Norman times - such as the construction of many castles ${ }^{137}$ and a rapid growth in the number, and size, of towns - ${ }^{138}$ there is no mention of any additional laws in respect of nuisance in this period. The four main highways continued to be treated as Royal roads, however. ${ }^{139}$

\section{(b) Laws of Henry I (c. 1113)}

The Laws of Henry I (c.1113) ${ }^{140}$ indicate that the Anglo-Saxon trinoda necessitas (including, the communal obligation to repair bridges) continued, since they stated:

These are the jurisdictional rights which the king of England has in his land solely and over all men, reserved through a proper ordering of peace and security....failure to perform burgbot or brigbot or firdfare [i.e. the obligation to repair fortifications and bridges and to serve in the army] ... ${ }^{141}$

These fortifications (defences) and bridges were Crown owned. The Laws also expanded the number of Royal roads (the king's highway). They now comprised roads which led to any city, castle or Royal town. ${ }^{142}$ Indeed,

\footnotetext{
${ }^{135}$ Robertson, n 20, p 235 et seq.

${ }^{136}$ As to the population at the time of the Norman Conquest it was, perhaps, 18,000. Guy, Bishop of Amiens in his Song of the Battle of Hastings (1067) described William I (as Duke William) turning his course 'to where crowded London gleams. The city is very large, full of rebellious citizens, and its wealth is greater than the rest of the kingdom. ' See K Tyson (trans), Bishop Guy D'Amiens, Carmen de Triumpho Normannico. The Song of the Norman Conquest (2014), p 105.

${ }^{137}$ Haslam, n 76, p 53 'The most immediate effects of the Conquest on the fabric of the townscape were twofold: firstly, the imposition of castles on to the existing urban layout, and secondly, the removal of many cathedrals to larger towns from smaller settlements.'

${ }^{138}$ Ibid, p 53 noted that 'this reflected political and military realities, a steadily increasing population and the introduction of new trading patterns.' Haslam asserted that some 47 new towns were founded in England in the period 1066-1140 and some 20 in Wales.

${ }^{139}$ Laws of William I (c. 1090-1135), Robertson, n 20, p 267 'If anyone slays or assaults anyone who is travelling through the country on any of the (following) four highways, namely, Watling Street, Ermine Street, the Fosse Way, the Icknield Way, he violates the King's Peace.'

${ }^{140}$ See Downer, n 22

${ }^{141}$ Ibid, p 109. Ibid, p 211 'If anyone fails to perform burgbot or brigbot or firdfare he shall pay compensation for this to the king to the amount of one hundred and twenty shillings in areas under English law...' Ibid, p 325 (Downer, editor) 'The obligation to contribute to the repair of fortifications as a defence against enemies [i.e. burgbot]; this, together with brigbot and firdfare, constitutes the trinoda necessitas which was imposed on all landowners and the history of which goes back to the Anglo-Saxon period.' Ibid, p 207 (fine for neglecting any of the trinoda necessitas).

${ }^{142}$ Ibid, p 249 'That is called a royal highway which is always open, which no one can close or divert with walls he has erected, which leads into a city or fortress or castle or royal town.'
} 
elsewhere, the Laws suggest that all highways belong to the king. ${ }^{143}$ This was a considerable extension to the position in the time of William I (1066-87) where the Crown's jurisdiction appears to have been restricted to 4 roads (see (a)). Over them the 'king's peace' (criminal jurisdiction) lay. Further, even if obstructing these Royal highways had not been a crime in Anglo-Saxon times (that of foresteal) ${ }^{144}$ it was by this date (i.e. c. 1113) since the Laws of Henry I state:

The compensation payable for stretbreche [street breach] shall be one hundred shillings. The offence of stretbreche occurs when someone destroys a road [via] by closing it off or diverting it or digging it up. ${ }^{145}$

Jurisdiction over this crime was reserved to the Crown and it was clearly distinguished from foresteal. ${ }^{146}$ Thus, the fine went to the Crown. It may also be noted that the stretbreche refers to a via (road) and not just to a royal road (regia via). This reflects the distinction made in the Laws of Edward the Confessor between Royal and public roads (see 3(c)).

- The Crown may also have franchised out its prerogative to collect fines in respect of Royal roads by this time. That is, lords of the manor acquired the right to judge the crime of stretbreche and to collect the fine;

- Further, one would suggest that the network of roads in England protected against obstructions was (probably) fairly extensive by the 12th century. The logic for this seems good, in that roads acted as important boundaries (as Bracton was to note, see 8(a)). Thus, they had a quasi-sacral nature - as well as their disturbance being likely to lead to a breach of the peace, that is, violence.

Finally, the Laws of Henry I referred to some minor, additional, nuisances. However, these were, effectively, private nuisances (though a distinction between private and public nuisances appears not yet to have been drawn) and subject to civil - and not criminal - liability. These nuisances were:

- $\quad$ mantraps ${ }^{147}$

- wells and cisterns; $;^{148}$

- $\quad$ an animal impaling itself on an enclosure etc. ${ }^{149}$

In conclusion, there is no sign of a generic crime of public nuisance in this period. However, there does seem to be a distinct crime of obstructing the king's (or a public) road, that of stretbreche.

\section{GLANVILL (c. 1189)}

The first legal text, Glanvill - which was published c. 1189 - considered nuisance from the perspective of purprestures. Thus, it stated:

There is a purpresture in the strict sense when there is an unjustifiable encroachment on property of the lord king: for example, in the royal demesnes, or by obstructing public ways [viis publicis] or diverting public watercourses [aquis publicis], or when anyone has encroached on royal land in some city of the lord king by building something. To put it generally, whenever anything is done to the nuisance [ad nocumentum] of a royal tenement or way or city, the resulting plea belongs to the crown of the lord king. ${ }^{150}$

\footnotetext{
${ }^{143}$ Ibid, p 109 'All highways are completely the concern of the king....'.

${ }^{144}$ See text to $n 111$.

${ }^{145}$ Downer, $\mathrm{n} 22$, pp 249-50. See also p 325. The Laws also provided for the width of the highway (likely to distinguish it from foot or horseways), p 249 'The highway should be wide enough for two wagons to meet and pass there, and for herdsmen to be able to make contact, with their goats at full length, and for sixteen knights, armed, to ride side by side.'

${ }^{146} \mathrm{Ibid}, \mathrm{p} 109$. 'These are the jurisdictional rights which the king of England has in his land solely and over all men...forestel....stretbreche...' See also p 249 'The offence of forestel occurs if someone attacks his enemy unexpectedly or lies in wait for him on the road and assaults him.'

${ }^{147}$ Ibid, p 279 'If anyone suffers any injury or mischief through the sudden discharge of a bow or ballista or because of a mantrap, erected for the capture of wolves or some other animal, the person who set it up shall pay amends.'

${ }^{148}$ Ibid, p 281 'If anyone digs a well or cistern or opens up one previously made and something falls in so that it suffers death or injury, he shall provide something of equal value to compensate, but may keep for himself the thing killed or injured.'

${ }^{149} \mathrm{Ibid}$, 'If an animal impales itself on an enclosure and the enclosure itself is not chin-high, the owner of the enclosure shall be adjudged responsible for any killing or injury.'

${ }^{150}$ Glanvill, n 23, pp 113-4. See also Coke, n 43, vol 2, p 272. Glanvill followed the Laws of Henry I (c. 1113) in recognising that the plea belonged to the Crown (see 4(b)) which, thus, recovered any fine. See also CHS Fifoot, History and Sources of the Common Law (1949), pp 3-4.
} 
Glanvill, effectively, treated public roads (or waterways) the same as Royal roads for the purpose of punishing any encroachment (obstruction) of the same. Glanvill indicated that these purprestures were prosecuted either in the chief curia or before the justices of assize. As to the punishment:

When anyone is convicted by such a jury of having made such a purpresture, the whole of the fee which he holds of the lord king shall be at the king's mercy, and he shall restore his encroachment. Moreover, if he is convicted of encroachment by building upon royal land in a city, then the buildings which are proved to have been built on royal territory shall belong to the lord king [i.e. forfeiture] and, notwithstanding this, he shall be liable to amercement by the lord king. Amercement by the lord king here means that he is to be amerced by the oath of lawful men of the neighbourhood, but so as not to lose any property necessary to maintain his position. ${ }^{151}$

As for purprestures against parties other than the king, if against his lord, the defaulter could be summoned by writ to make restitution. Glanvill stated:

when anyone makes a purpresture against someone other than the king, it is either against his lord or a stranger. If it is against his lord, and is not within the assize ${ }^{152}$ then the encroacher shall, if he holds another tenement [i.e. land] of that lord, be constrained by the following writ to come to his lord's court to make restitution. ${ }^{153}$

A person convicted of the offence in the lord's court lost the tenement he held. If he held no other tenement, he could be impleaded by a writ of right in the court of the chief lord. ${ }^{154}$ Thus,

if anyone makes an encroachment in this way on another who is not his lord [i.e. a stranger], and it is not within the assize, the case shall be pleaded by writ of right. But if the acts are done within the assize, then the recognition of novel disseisin is available to recover seisin [possession]. ${ }^{155}$

Glanvill also noted that:

In the making of such purprestures the boundaries of land are often broken across and encroached upon; in such a case, if either of the neighbours complains of this in court, the sheriff shall be commanded by the following writ to have a view of those boundaries taken by lawful men of the neighbourhood and, in accordance with their oaths, to cause them to be restored as they ought to be and customarily were in the time of king Henry, [Henry I, 1100-35] grandfather of the lord king [Henry II, 1154-89]. ${ }^{156}$

This reflects the troubled times in the reign of king Stephen (1135-54) when England was at civil war which resulted in the seizure of land and (likely) the destruction of boundaries due to the destruction of landmarks such as roads, rivers, banks and boundary stones. To prevent further violence, it seems clear legal opportunity was given to revert to the former position.

\footnotetext{
${ }^{151}$ Ibid.

${ }^{152}$ Hall (the editor) notes 'Probably meaning that the period of limitation laid down for [the assize of] novel disseisin has passed, and that the assize is not available.' HM Chew \& Kellaway, London Assize of Nuisance 1301-1431 (London Record Society, 1973), p xii 'The assize of nuisance according to Glanvill had its origins in a variant writ of novel disseisin. A freeholder might be disseised of some part of his tenement and the injury was said to be 'ad nocumentum liberi tenementi.'

${ }^{153}$ The writ was in this form 'The king to the sheriff, greeting. I command you to constrain N to come without delay to the court of R his lord, to defend there a claim made by his lord, who alleges that he encroached on his free tenement; that the lord need no longer complain of default of justice in this matter. Witness, etc.'

${ }^{154}$ Glanvill, n 23, p 115 'If he is convicted of the offence in the lord's court, he shall lose for ever the tenement which he held of that lord [i.e. by escheat]. If, however, he holds no other tenement of the same lord, then the lord shall implead him by a writ of right in the court of the chief lord.'

${ }^{155}$ Ibid. Walker, n 5(writ of right) 'A writ obtainable as a matter of right, as contrasted with a prerogative writ, granted in the exercise of the royal prerogative as a matter of discretion only. In older real property law a writ of right was the real action which lay to enable a person to recover land in fee simple unjustly withheld from him. It was used where the person dissesised had lost his right of entry or right to possession because, otherwise, a possessory action such as a writ of entry was more convenient.'

${ }^{156}$ The writ for making reasonable boundaries between different tenements was: 'The king to the sheriff greeting. I command you to establish, justly and without delay, reasonable boundaries between the land of R in such-and-such a vill and the land of Adam de Biri in Biri, as they ought to be and customarily are, and as they were in the time of king Henry [Henry I, 1100-35] my grandfather, concerning which R complains that Adam has, unjustly and without a judgment, occupied more than belongs to his free tenement in Biri; that I may hear no further complaint of default of justice in this matter. Witness, etc.' One would agree with J Loengard, The Assize of Nuisance, Origins of an Action at Common Law [1978] CLJ 144, pp 144-5 that the impetus for the assize of nuisance (likely) grew out of the reaction to the upheavals of the reign of Stephen. As to the origin of the assize of nuisance, Loengard did not cite the Laws of Edward the Confessor (see 3(c)). Regardless of whether this text does reflect Anglo-Saxon law, it suggests that - when it was redacted (c. 1140's) - encroachments on public roads, waterways and boundaries were subject to legal redress. Indeed, it is asserted that legal protection (likely) occurred even earlier since roads etc were important for defence, for commerce (people going to markets) and for land ownership - with highways, rivers, hedges, boundary stones etc being the only way to identify who owned what in early times.
} 
In conclusion, the first legal writer - Glanvill - writing c. 1189, considered purprestures (encroachments) on Royal or public highways and waterways (treating them the same for such purposes).

\section{LONDON - $\underline{1189}^{157}$}

Glanvill did not mention nuisances other than encroachments. Nor did he mention the Assize of Building of 1189 (see below) promulgated in respect of London.

- It might - legitimately - be expected that the law of nuisance would first develop in London since it seems to have always possessed the largest population among the English cities. Here, the first local (subordinate) legislation appears to have been in 1189 (although the date of this Assize can be disputed). It dealt with nuisances arising from building;

- Whether there was prior local legislation is uncertain since the history of London (part of the kingdom of Mercia along with Middlesex) is uncertain after the Norman Conquest.

However, as to the governance of London, post-Conquest, the following may be noted:

- $\quad$ Shire Reeve. It seems likely the Anglo-Saxon shire reeve (sheriff) continued to govern the City after 1066 - albeit under the authority of William I (1066-87). ${ }^{158}$ The names of these shire reeves (sheriffs) are known from 1154 onwards. ${ }^{159}$ By a charter of c.1132, London ${ }^{160}$ and Middlesex were leased by Henry I (1100-35) to the citizens of London. Various privileges were also granted to the citizens - including the right to appoint two sheriffs - one for the City and one for Middlesex - as well as to appoint a justiciar (to handle pleas of the Crown). ${ }^{161}$ The sheriffs were responsible for collecting the rent (and other taxes) as well as for enforcing the criminal law; ${ }^{162}$

- Mayor. In c.1189, a mayor was appointed for London; the first being Henry FitzAilwin. ${ }^{163}$ Until 1215, the mayor was (likely) appointed by the sovereign. However, a charter of king John (1199-1216) of 1215 provided that the citizens (the barons) 'may choose to themselves every year a mayor'; ${ }^{164}$

- $\quad$ Aldermen. The word derives from Anglo-Saxon times. ${ }^{165}$ They presided over each ward. It seems that the office, in early times, was for life. ${ }^{166}$ The first (fairly full) list of London aldermen dates from $1127 .{ }^{167}$ It also seems likely that London was divided - at least from 1111 - into 24 wards, each with its own alderman ${ }^{168}$ and its own wardmote (moot or court) which he presided over. ${ }^{169}$ These wardmotes were summoned twice a year (see also below);

\footnotetext{
${ }^{157}$ For a useful chapter (and map) on London in the 1170's, see Brooke, n 78, ch 5.

${ }^{158}$ The 1st charter of William I (c. 1067) referred to Gosfrith (probably, Geoffrey de Mandeville), the port reeve who was also sheriff of Middlesex. However, there may have been two sheriffs the time of the Norman Conquest (one for London and one for Middlesex). The sheriff was also referred to by the Anglo-Norman term, bailiff. See McBain, n 66, pp 5-7.

${ }^{159}$ Brooke, n 78, p 41 and Appendix II.

${ }^{160}$ The charter does not refer to London but to Middlesex. However, London was within the latter.

${ }^{161}$ See McBain, $\mathrm{n}$ 66, p 6. The charter of c. 1132 states 'I have granted to my citizens of London, to hold Middlesex to farm for [an annual quit rent of £300], upon accompt to them and their heirs; so that the citizens shall place as sheriff whom they will of themselves and shall place whomsoever [justiciarium, a justiciar], or such a one as they will of themselves, for keeping of pleas of the crown...'. The office of justiciar became extinct after 1265 .

${ }^{162}$ Ibid, p 6 'The sheriff was an executive officer of the Crown responsible for collecting taxes and enforcing the law. However, prior to the Norman Conquest, the sheriff had ceased to collect rents on behalf of the sovereign. Instead, he became a rent collector or farmer (firmarius), buying the right to such revenues in return for a fixed annual rent or farm (firma comitatus) which he paid to the exchequer, for the sovereign.'

${ }^{163}$ See generally, Brooke, n 78, ch 9 and Appendix III. See also McBain, n 66, p 19.

${ }^{164}$ Ibid. The charter of 9 May 1215 stated that the citizens 'may choose to themselves every year a mayor, who to us may be faithful, discreet, and fit for government of the city, so as, when he shall be chosen, to be presented to us, or our justice[s] (if we shall not be presented); and he shall swear to be faithful to us...'

${ }^{165}$ Liber Albus, n 64, p 29 'alde' in Saxon means 'old', and alder is our word 'older'; and hence, as the judgment is most vigorous in persons of more mature years, the dignitary who among the Romans was known as 'consul' or 'senator', among us is called 'Alderman.'

${ }^{166}$ Ibid, p 32.

${ }^{167}$ Brooke, n 78, p 31. Ibid, p 155 'Down to the reign of Cnut an alderman, ealdorman, was the headman of a shire, a leading noble; from then on the Danish jarl, earl, replaced the title. 'Alderman', however, survived in its more general sense of a headman of a ward (first recorded in 1111) or of a guild; and so to the leading men of any city, as it has survived to the present day.'

${ }^{168}$ Ibid, ch 7.

${ }^{169} \mathrm{Ibid}, \mathrm{p} 167$. Brooke asserted that the word 'wardmote' was an error for the word 'vadimonia', found in the early 13th century text of the charter of Henry I (1100-35) of c. 1132. See also CT Lewis \& C Short, A Latin Dictionary (Oxford, 1890)(vadimonium) 'a promise secured by bail for appearance on a particular day before a tribunal, bail, security, recognizance.'
} 
- $\quad$ Commune. In 1191, London became a commune. ${ }^{170}$

As for London in the 12th century, a glowing accolade was provided by Fitzstephen (a cleric in the service of Thomas Beckett) in his Description of London (c. 1174-83). ${ }^{171}$ Declaring that it stood head and shoulders above other cities of the world, ${ }^{172}$ he noted the following:

(The cultivated gardens) Beyond the suburban houses, on every side and adjacent to each other, the citizens have beautiful and spacious gardens, planted with trees.

(The pastures). To the north [of the city] there are tilled fields, pastures, and pleasant, level meadows with streams flowing through them, where watermill wheels turned by the current make a pleasing sound. Not far off spreads out a vast forest, its copses dense with foliage concealing wild animals - stags, does, boars, and wild bulls.

(The fields). The arable fields of the city are not gravelly and parched, but are like the fertile fields of Asia which make 'glad the crops'; their cultivation fills the granaries 'with sheaves of Ceres' stalk'.

(The daily routine of the City). Every morning you can find those carrying on their various trades, those selling specific types of goods, and those who hire themselves out as labourers, each in their particular locations engaged in their tasks. Nor shall I forget to mention that there is in London, on the river bank amidst the ships, the wine for sale, and the storerooms for wine, a public cookshop. On a daily basis there, depending on the season, can be found fried or boiled foods and dishes, fish large and small, meat - lower quality for the poor, finer cuts for the wealthy - game and fowl (large and small)...No matter how great the number of soldiers or travellers coming in or going out of the city, at whatever hour of day or night, so that those arriving do not have to go without a meal for too long or those departing leave on empty stomachs, they can choose to detour there and take whatever refreshment each needs....

(Smithfield) ${ }^{173}$ In a suburb immediately outside one of the gates there is field that is smooth, both in name and in fact. Every Friday (unless it is an important holy day requiring solemnity) crowds are drawn to the show and sale of fine horses. This attracts the earls, barons and knights who are then in the city, along with many citizens, whether to buy or just to watch. ...Prospective buyers watch as all are put through their paces... In a separate part are located the goods that country folk are selling: agricultural implements, pigs with long flanks, cows with swollen udders 'woolly flocks and bodies huge of kine.' Also to be found there are mares suited for pulling ploughs, sledges, and two-horse carts...

(Ships and Commerce). Middlemen from every nation under heaven are pleased to bring to the city ships full of merchandise...

Others did not paint London in such glowing terms. Richard of Devizes (a Winchester cleric), writing in 1192 , stated:

All sorts of men crowd together there from every country under the heavens. Each race brings its own vices and its own customs to the city. No one lives in it without falling into some sort of crime. Every quarter of it abounds in grave obscenities. The greater a rascal a man is, the better a man he is a accounted... Whatever evil or malicious thing that can be found in every part of the world, you will find in that one city. Do not associate with the crowds of pimps; do not mingle with the throngs in eating-houses; avoid dice and gambling, the theatre and the tavern. You will meet with more braggarts there than in all France; the number of parasites is infinite. Actors, jesters, smooth-skinned lads, Moors, flatterers, pretty boys, effeminates, pederasts, singing and dancing girls, quacks, belly-dancers, sorceresses, extortioners, night-wanderers, magicians, mimes, beggars, buffoons: all this tribe fill all the houses. Therefore, if you do not want to dwell with evil-doers, do not live in London. ${ }^{174}$

\footnotetext{
${ }^{170}$ Ibid, pp 45-7.

${ }^{171}$ The text was in latin (Descriptio Londoniae). See Liber Custumarum, n 65, pp 2-15. It was translated by J Stow, Survey of London (first pub 1598, see reprint by Dent \& Sons, 1965), pp 501-9. However, Stow added his own poetic flourishes to the text. The Florilegium Urbanum (see www.trytel.com/-tristan/towns/florilegium/introduction) also has a translation with notes, which I have preferred. See also Brooke, $\mathrm{n} 78$, pp 112- 6.

${ }^{172}$ Ibid 'Among the splendid cities of the world that have achieved celebrity, the city of London - seat of the English monarchy - is one whose renown is more widespread, whose money and merchandize go further afield, and which stands head and shoulders above the others.' See also The Tristan of Thomas (trans. AT Hatto, 1960), a work by the French poet, Thomas, c. 1160 which stated 'London is a very noble city; there is none better in Christendom or any of higher worth, of greater renown, or better furnished with well-to-do people. For they much love honour and munificence and bear themselves very gaily. London is the mainstay of England....At the foot of its wall there flows the Thames, by which merchandise comes from every land where Christian merchants go.'

${ }^{173}$ This was West Smithfield. The word 'smith' in the name may have originally been 'smooth'.

${ }^{174}$ Brooke, n 78, p 181. For another translation see JA Giles, The Chronicle of Richard of Devizes (1841), pp 60-1.
} 
The population of London in 1189 is unknown. However, it has been conjectured that it was in the region of $\mathrm{c}$. 18,000 persons. ${ }^{175}$

\section{(a) Nuisance - Assize of Building 1189}

By this date, the number of buildings in London was sufficient to require local legislation and an Assize relating to building was passed in 1189 . It stated:

In the year of our Lord 1189, in the first year, namely, of the reign of the illustrious king Richard [I, 1189-99], Henry Fitz-Elwyne (who was the first mayor of London) being then mayor, it was, by the more discreet men of the city [thus] provided and ordained, for the allaying of the contentions that at times arise between neighbours in the City touching boundaries made, or to be made, between their lands, and other things; to the end that, according to the provisions then made and ordained, such contentions might be allayed.

This legislation was called an 'Assize' ${ }^{176}$ and it was enforced by the Aldermen ${ }^{177}$ in the Court of Hustings (or, if it was not sitting, before the Mayor and the Alderman). ${ }^{178}$ The Assize noted the need for stone walls in the City since the lack of them had caused the City to be burned, in great part, in former times. Thus, it stated:

in ancient times the greater part of the City was built of wood, and the houses were covered with straw, stubble and the like. Hence it happened, that when a single house had caught fire, the greater part of the City was destroyed through such conflagration; a thing that took place in the first year of the reign of king Stephen [i.e. 1135], when, by reason of a fire that broke out at London bridge, the church of Saint Paul was burnt; from which spot the conflagration extended, destroying houses and buildings, as far as the church of Saint Clement Danes [now, situated by the Royal Courts of Justice on the Strand]. ${ }^{179}$

This statement is useful in that it indicates there was no legal regulation of building prior to 1135 and, indeed, that this ordinance of 1189 was the first attempt. The terms of the Assize were surprisingly modern and it dealt with a range of matters designed to suppress contentions between neighbours. ${ }^{180}$ In particular, it expressly used the word 'nuisance' stating, for example:

if any one shall make a pavement unjustly in the king's highway, to the nuisance of the City and of his neighbour [ad nocumentum civitatis et vicini sui injuste], such neighbour may rightfully prevent it, through the bailiffs [sheriffs] of the City; and so it shall remain, until the matter shall have been discussed and determined by the men of the Assize. ${ }^{181}$ (italics supplied)

\section{(b) Nuisance - Sales of Food, Drink \& Products}

As might be expected - with the growing population of London - there was a need to regulate the sale of food and drink as well as other products.

- In 1197, Richard I (1189-99) promulgated an Assize of Measures and, in 1199, king John (1199-1216) an Assize of Wine. ${ }^{182}$ Magna Carta (1215) also specified measures. ${ }^{183}$ An Assize was a form of legislation; ${ }^{184}$

\footnotetext{
${ }^{175}$ Fitzstephen indicated that - in the reign of king Stephen (1135-54) - there were in London, 20,000 horsemen fit for war and 60,000 infantry. However, this is a manifest exaggeration unless it also was intended to cover Middlesex generally.

${ }^{176}$ Liber Albus, n 64, p 277.

${ }^{177}$ Ibid 'To prosecute which Assize, and carry the same into effect, twelve men were elected Aldermen of the City, in full Hustings; and were there sworn, that they would attend faithfully to carry out the same, and at the summons of the Mayor to appear, unless by reasonable cause prevented. It was necessary however that the greater part of the twelve men aforesaid should be present with the Mayor in carrying out the matters aforesaid.'

${ }^{178}$ Ibid. 'It should be known, that he who demands the Assize must demand it in full Hustings; and the mayor shall assign him a day within the next eight days, for such assize by the twelve men aforesaid, or the greater part of them, in the manner already mentioned, to be determined.'

${ }^{179}$ Ibid, p 284. It continues 'After this, many of the citizens, to the best of their ability to avoid such a peril, built stone houses upon their foundations, covered with thick tiles, and [so] protected against the fury of the flames...' See also Chew, n 152, p ix 'London was much afflicted by fire in the eleventh and twelfth century. In a period of less than one hundred and fifty years there were, perhaps, as many as five major conflagrations.' The fire in the reign of Stephen may have been in 1133, not 1135.

${ }^{180}$ Thus, the Assize dealt with: inter alia, (a) buildings erected between neighbours; (b) stone walls between neighbours; (c) rain gutters; (d) cesspits; (e) obstruction of the view from windows; (f) corbels (projections); (g) rainwater etc.

${ }^{181}$ Liber Albus, n 64, p 286.

${ }^{182}$ W Stubbs, The Constitutional History of England (Clarendon, 1883), vol 1, p 616 noted 'The Assize of Measures was issued in the name of Richard I by the justiciar in 1197, as made by the lord Richard king of England at Westminster, although the king was at the time in France, by the petition and advice of his bishops and all his barons.'
} 
- Given the likely population of London in the period 1066-1189, it seems probable there was some sort of legal regulation of these matters prior to this. However, City records (as published) do not go sufficiently far back to evidence it. Thus, the published Letterbooks of the City commence in 1275, the Calendar of Early Mayor's Court Rolls in 1298 and the Calendar of Plea and Memoranda Rolls in 1323.

Further, it may be that the Assize of Richard I in 1197 was one of the first pieces of legislation promulgated by a sovereign, post-Conquest. However, this does not mean that - prior to 1197 - there was no punishment for, for example, selling goods: (a) not according to due weight or measure; or (b) not according to description; or (c) which were defective in some way (such as putrid food). The punishments of the pillory and the tumbrel (dung cart) - used in medieval times for such crimes - are very old and, at least, the pillory seems to have existed in Anglo-Saxon England (the healsfang) to punish similar matters. ${ }^{185}$ Further, the common law crime of 'deceite' (pretence) a concept, later, covered by the offence of 'cheat' (the word 'cheat' deriving from 16th century Romany cant) - are also very old. They, probably, existed in Anglo-Norman times and would have been employed to punish such nuisances. However:

- It is unlikely there was a composite offence of 'common nuisance' prior to 1191 since the epithet 'common' ('public') is apposite to the period after London became a commune in 1191 ;

- Thereafter, use of the epithet 'common' may be found. For example, the liverymen of the City met in 'common hall' and the elected representatives - known as 'common councilmen' - met in 'common council.' There were also other references such as: common highway, common law, common sewer, common prostitute, common drunkard etc. ${ }^{186}$

\section{(c) Other Nuisances - Bawdy House}

Another nuisance (likely) dealt with in 12th century London (and elsewhere in the country) were unlicensed brothels. As previously noted, in Anglo-Saxon times, these, probably, did not exist (at least, officially) since legislation provided for the expulsion of prostitutes (see 3(c)). Further, William I (1066-87) laid waste to Southwark in December 1066, (likely) destroying any brothels which may have existed there. However, since William's army consisted of some 12,000 men - half of which were mercenaries (mainly Flemish) - this may have resulted in a change in morals over time.

- Southwark Brothels. As it is, it would seem that an Ordinance of Henry II (1154-89) of 1161 established 18 brothels (stewhouses) in Southwark. The bishop of Winchester had a manor there and the whole of the south bank lay within his diocese. ${ }^{187}$ The wording of the Ordinance ${ }^{188}$ suggests that brothels may have existed a considerable

\footnotetext{
${ }^{183}$ Magna Carta 1215, ch 35 'Let there be one measure of wine throughout our whole realm, and one measure of ale, and one measure of corn, to wit, the London quarter and one width of cloth (whether dyed, or russet, or 'halberget', to wit, two ells within the selvedges; of weights also let it be as of measures.' See also Coke, n 43, vol 2, p 41 and WS McKechnie, Magna Carta (1914), pp 356-8.

${ }^{184}$ Walker, n 5, (Assise or Assize) 'This term, literally, a 'session', was first used of a legislative enactment, such as the Assise of Clarendon or the Assize of the Forest. ' See also McKechnie, n 183, p 272n 'The name 'Assize' is sometimes a source of confusion, because of its various meanings. (1) Originally, it denoted a session or meeting of any sort. (2) It came to be reserved for sessions of the King's Council. (3) It was applied to any ordinance enacted in such a session, e.g. Assize of Clarendon. (4) It was extended to every institution or procedure established by royal ordinance, but (5) more particularly applied to the procedures known as Grand Assize and Petty Assizes.' See also OED, $\mathrm{n} 4$ (assize) and W Stubbs, The Constitutional History of England (Clarendon, 1883), vol 1, pp 614-6.

${ }^{185}$ Coke, n 43, p 218 'Pillory is a French word, and it is derived of the French word pilastre a pillar, columna....this punishment is very ancient, for the Saxons called it heals fang, so called for straining the neck.' Ibid, p 219 'Tumbrell is a word in use at this day for a dungcart...And every one that has a leet or market ought to have a pillory and tumbrell, etc, to punish offenders, as brewers, bakers, forestallers etc.'

${ }^{186}$ See n 6. See also Lex Londinensis or the City Law (1680), p 73 (common dicer, common player at unlawful games, common picker etc).

${ }^{187}$ The Bishop of Winchester, later, built a palace there (it was completed in 1144 and it was, mostly, destroyed by fire in 1814). As to the history, the estate of Bermondsey in Southwark was owned by William I (1066-87) with some of it also owned by his half brother, Robert, Count of Mortain. In 1089 or 1090, this estate was given by king Willam Rufus (1088-1100) to the monks of Bermondsey. In 1107, William Giffard (1100-29), Bishop of Winchester - who was also Lord Chancellor (1093-1101) - acquired some of this land from the monks of Bermondsey for $£ 8$ p.a. rent and later built his palace there. This land (to the West of London Bridge) became known as the Liberty of the Clink since - from 1144 - it housed 2 prisons (one for men and one for women) and the expression the 'Clink' referred to them. It was a 'Liberty' since it was a private jurisdiction of the Bishop of Winchester, as lord of the manor, and not subject to the legal jurisdiction of the City. In 1791, T Pennant, Some Account of London (2nd ed, 1791), p 50 noted 'The Clink, or manor of Southwark, is still under the jurisdiction of the bishops of Winchester...'

${ }^{188}$ EJ Burford, Bawds and Lodgings: A History of the London Bankside Brothels c. 100-1675 (Peter Owen, 1976), p 44 cites a manuscript in the Bodleian Library, Oxford. It commences (modernising the English) 'This act and ordinance was made as hereafter appears in this book in the Parliament held in Westminster in the 8th year of the reign of king Henry [1161] by all the assent of the Commons and so confirmed by the king and all the lords of the said Parliament in the same year and time of Parliament there so held Theobald then being Archbishop of Canterbury [1139-62] and Thomas Becket then being archdeacon of the same.' See also McBain, $\mathrm{n} 90$.
} 
time prior to this ${ }^{189}$ - something the criticisms of the Winchester cleric Richard of Devizes (writing in 1192, see above) suggest - although Fitzstephen (c. 1174-83) declared that London was famous for the chastity of its matrons. ${ }^{190}$ These descriptions may not be wholly contradictory since it is thought that the Southwark brothels were generally staffed by Flemish women; ${ }^{191}$

- Occasional Destruction of the Brothels. Southwark was periodically ravaged ${ }^{192}$ - including in 1212 . Further, the brothels were, often, targets of violence, such as in $1381 .{ }^{193}$ Thus, even these licensed brothels did not escape destruction.

\section{In conclusion, brothels elsewhere in London would (likely) have been suppressed from 1161 (if not before) as 'disorderly houses' (the words 'brothel' and 'bordello' were not use to describe such houses until later times).}

\section{(d) London: Wardmotes}

As to how nuisances would have been prosecuted in 1189, this would have been before the wardmote courts. That is, the hundred courts in London. ${ }^{194}$ Fitzstephen (c. 1174-83) stated that London:

like Rome, is divided into wards; it has annual sheriffs instead of consuls; it has an order of senators [aldermen] and inferior magistrates and also sewers and aqueducts in its streets; each class of suits, whether of the deliberative, demonstrative, or judicial kind, has its appropriate place and proper court; on stated days it has its assemblies. ${ }^{195}$

The Liber Albus (1419) provided:

The wardmote is so called as being a meeting together by summons of all the inhabitants of a ward, in presence of its head, the alderman, or else his deputy, for the correction of defaults, the removal of nuisances, and the promotion of the well-being of such ward. The meetings that we call 'wardmotes', the Romans called 'plebiscita;' the same in fact that were styled 'folkesmoot' by the Saxons in ancient times. ${ }^{196}$

The wardmote (ward meeting) was summoned by the mayor directing (by warrant) the alderman of each ward to hold a wardmote at least twice a year or more often. The alderman then commanded his bedel (beadle) to empanel a jury to whom a wardmote 'inquest' (inquiry) should be made. ${ }^{197}$ The articles of inquisition of the wardmote were read out to the jurors, to which they gave their presentment (verdict). ${ }^{198}$ Then:

The alderman ought also, in his own person, to supervise and correct all defaults and nuisances presented by the jurors at the wardmote aforesaid, unless perchance any matters of difficulty should arise, and of a nature bearing

\footnotetext{
${ }^{189} \mathrm{Ibid}, \mathrm{p} 44$, Burford cites the Bodleian manuscript as stating (modernising the English) 'we ordain and make to the said lord's avail divers ordinances and constitutions to be kept for evermore within the said lordship and franchise according to the old customs that have been used and accustomed there time out of mind which now of late were broken, to the great displeasure of God and great hurt unto the lord and utter undoing to all his poor tenants there dwelling and also to the great multiplication and horrible sin with the single women which ought to have their free going and coming at their own liberties as it appears by the old customs thereof afore made out of time of mind for the eschewing of these inconveniences and of all other inconveniences and of all other their coming.'

${ }^{190}$ Fitzstephen's text, n 171, refers to the 'respectability of its citizens, and the propriety of their wives ' and that 'The married women of the city are true Sabines. ' See also Stow, n 171, pp $501 \& 503$.

${ }^{191}$ See McBain, n 90, p 24, n 81.

${ }^{192}$ The Anglo-Saxon Chronicle, n 72, p 159 says that in 1077 [on the 14th August] 'London was burned down one night...worse than ever it had been since it was founded.' Ibid, p 163 'in [1087] the holy minister of St Paul, the cathedral church of London, was burnt down, and many other churches, and the largest and noblest part of the City.'

${ }^{193}$ In July 1212, a fire broke out in Southwark and swept into London, killing at least 3000 people. G Home, Medieval London (1927) p 103. Brooke, $\mathrm{n}$ 78, p 53. And, in 1381, a brothel was destroyed in the Peasant's Revolt, see McBain, n 90, p 24. See RB Dobson, The Peasant's Revolt of 1381 (1970), pp 156, 162 \& 175.

${ }^{194}$ The wardmote was often described by writers as the London equivalent of the hundred court. However, even if initially so, it soon ended up as the court leet dealing only with minor infractions of the law.

${ }^{195}$ See $\mathrm{n} 171$.

${ }^{196}$ Liber Albus, n 64, p 32

${ }^{197}$ Ibid 'the bedel is to present to the alderman a panel, arrayed by the constables of the ward, of those reputable men of such ward by whom inquisition should be made; which array, if the alderman shall deem it expedient, he shall be at liberty to amend.'

${ }^{198}$ Ibid 'the jurors are to have read to them all the articles touching such wardmote...After this, a certain day for making their presentment is to be given by the aldermen to the jurors. On which day the jurors are to present their verdict indented, one part of it to remain in possession of the alderman, and the other with the ward. It is the duty also of the alderman to present his part to the mayor, at the sitting of the next general court; to the end that, after it has been seen and enquired if there is any matter the correction of which pertains unto the mayor and city, the aforesaid indenture may be re-delivered to him, to be acted upon in other respects, etc.'
} 
reference to the Chamber; ${ }^{199}$ matters of which description the mayor and chamberlain, aided by the sheriffs and other officials, shall take in hand.

At the wardmote other official matters were also dealt with:

- There was elected by the alderman and the reputable men of the ward and the jurors various officials - such as scavagers, ale conners (ale testers), the bedel and others; ${ }^{200}$

- The bedel certified the names of hostellers (hotel keepers), brewers, bakers, cooks, victuallers and auctioneers living in the ward, since these professions were regulated;

- The alderman also sealed the weights and measures for each ward; ${ }^{201}$

- Those not freemen of the City were put into frankpledge, taking the relevant oath ${ }^{202}$ and paying the requisite sum.

As can be seen, therefore, the wardmote enabled a strict regulation to be kept on everyone within the ward as well as provided the means to remedy - and to punish - any nuisances. The uncertainty is when the wardmote system first commenced. They may have existed the same time as London was divided up into wards which seems to have occurred, at least as early as 1111 (see above). However, it is possible that wardmotes existed from the Norman Conquest (or even before) in some form.

\section{(e) $\underline{\text { Conclusion }}$}

After 1197, there was an Assize of Measures and an Assize of Wine. However, such 'Assizes' were statutory in nature, being acts of the king in Council. Thus, a breach of them would not have been treated as a common nuisance as such. Further, London only became a commune in 1191. Therefore, it is unlikely the term 'common nuisance' would have been employed prior to then. Thus, there is no evidence of any generic crime of 'common nuisance' at common law in London in early times. That does not mean to say that various nuisance - such as throwing rubbish into the highway or selling bad wine or rotten food - would not have been punished. However, in the absence of statutory regulation, such would (likely) have been punished under the common law offence of 'deceite' (later called 'cheat').

\section{MAGNA CARTA (1215)}

It would seem that one of the major nuisances affecting the general populace in early times was the placing of fish weirs (fish traps) in the Thames - and in other major rivers - to catch fish, the effect of which was to impede, or prevent, navigation. These traps were also called 'kidels' (there are variant spellings). ${ }^{203} \mathrm{Charters}$ granted by Richard I (1189-99) in 1197 and by king John (1199-1216) in 1199 to the City - as well as one granted by Henry III (1216-72) in 1227 - and various subsequent ones ${ }^{204}$ - provided for the removal of kidels from the Thames and the Medway rivers. ${ }^{205}$ The removal of this nuisance was made general in Magna Carta (1215), chapter 33 of which stated:

All kydells for the future shall be removed altogether from Thames and Medway, and throughout all England, except upon the sea shore. ${ }^{206}$

\footnotetext{
${ }^{199}$ A reference to the Mayor and Aldermen of the Outer Chamber of the City. See also McBain, n 66, p 12.

${ }^{200}$ Liber Albus, n 64, p 34. A note by the editor (Riley) stated that scavagers were 'officers whose duty it was originally to take custom upon the scavage, i.e. inspection of the opening out, of imported goods. At a later date, part of their duty was to see that the streets were kept clean; and hence the modern word 'scavager', whose office corresponds with that of the rakyer (raker) [rubbish collecter] of former times.'

${ }^{201}$ Ibid 'It was the usage also for the aldermen to seal the measures and weights in their respective wards, and to condemn such as were not sealed, receiving a remuneration for such sealing to their own proper use, in the same way that the City Chamber now receives it. For every ward had its own measure, made of brass, and corresponding with the royal standard of the city.' Aleconners dealt with breach of assize, false weights and measures, unwholesome drink etc. Fleshtasters dealt with corrupt victuals. The constable dealt with the nightwalker (noctevagus) and disorderly houses (brothels). See also Ritson, n 120, p xiii.

${ }^{202}$ Ibid. Riley (editor) in a note stated it was an oath 'To be bound, mutually with others, for their respective good behaviour; a usage of Anglo-Saxon origin.'

${ }^{203}$ OED n 4 (kiddle) 'a. A dam, weir, or barrier in a river, having an opening in it fitted with nets or other appliances for catching fish.'

${ }^{204}$ See Liber Albus, n 64, pp 118 (Richard I); p 119 (John); p 120 (Henry III); pp 130 and 133 (Edward III); pp 137 and 142 (Richard II); pp 146 and 149 (Henry IV).

${ }^{205}$ McKechnie, n 183, p 345. See also McBain, n 66, pp 52-60 (synopsis of charters). See also JC Holt, Magna Carta (1969), pp 49, 60.

${ }^{206}$ Ibid, p 343 (omnes kydelli de cetero deponantur penitus de Tamisia, et de Medewaye, et per totam Angliam, nisi per costeram maris). Ibid, p 343 'The object of this provision... was intended to remove from rivers all obstacles likely to interfere with navigation...The waterways were the great avenues of commerce; when these were blocked, townsmen and traders suffered loss, while those who depended on
} 
The placing of kidels was a constant problem and they were destroyed as a form of nuisance. ${ }^{207}$ However, this was by virtue of legislation (Magna Carta) and not the common law.

\section{BRACTON (c. 1240), EYRES \& STATUTE OF WALES 1284}

\section{(a) Bracton}

In his, On the Laws and Customs of England (c.1240), ${ }^{208}$ Bracton considered nuisance in some detail. He did so in the context of the assize (that is, the procedure) of novel disseisin. ${ }^{209}$ He noted that some nuisances were harmful - but not wrongful - while others were also wrongful. ${ }^{210}$ For example, it was not wrongful to put a mill on one's own land. Bracton also noted that the number of nuisances which destroyed servitudes completely - or kept them from being used effectively - were infinite. ${ }^{211}$ Bracton gave various examples:

- $\quad$ Watercourse. If a watercourse (a channel for water, such as a riverbed) was diverted, causing damage to a neighbour, this was a nuisance; ${ }^{212}$

- $\quad$ Pasturage. A person with a servitude of pasturage (i.e. a right to graze animals) had a right of entrance and exit. If this was blocked, this was a nuisance; ${ }^{213}$

- $\quad \underline{\text { Road. }}$. The obstuction of a road was a nuisance. ${ }^{214}$

- Digging, Hunting, Fishing etc. The obstruction of these servitudes comprised nuisances. ${ }^{215}$

Bracton noted that such servitudes were among the 'apputenances' (appendages) of tenements (land). And, that they were apputenant from one tenement to another (that is, from one piece of land to another adjacent to it). ${ }^{216}$ Further, the assise of novel disseisin included nuisance since:

them for necessaries, comforts, and luxuries, shared in the general inconvenience. Magna Carta mentions only one kind of impediments, namely 'kydells' (or fish-weirs), not because of the purpose to which these were put, but because they were the form of obstruction that called for repressive measures at the moment. This word seems to have been used by the framers of Magna Carta in a wide general sense, embracing all fixed contrivances or 'engines' intended to catch fish, and likely by their bulk to interfere with the free passage of boats.'

${ }^{207}$ See also Letterbook A, n 66, p 185 (1313, burning of a false kidel). Also, JW Jeudwine, Tort, Crime and Police in Medieval Britain (Williams \& Norgate, 1917), p 219 and T de Laune, Angliae Metropolis (1690), pp 186-96.

${ }^{208}$ Bracton, $\mathrm{n} 24$

${ }^{209}$ Walker, n 5(1980) (novel disseisin, assize of) 'A procedure established by enactment of Henry II (the Assize of Clarendon) in 1166, whereby if one person were dispossessed (disseised) of his free tenement unjustly and without a judgment, he was to have a remedy by royal writ in that a jury of 12 free and lawful men of the neighbourhood was to be summoned and in the presence of the king's justice to answer whether the disseisin was unjustified or not. The importance of this ordinance was that lawful possession, as distinct from ownership, was to be protected by a rapid remedy and that seisin was to be protected by the king, no matter from what lord the lands were held. One man could not turn another out of possession without a judgment. The procedure survived until 1833.' See also Spencer, n 3, pp 56-7.

${ }^{210}$ Bracton, n 24, vol 3, p 189 'It is clear that some nuisances are wrongful and harmful, others harmful and not wrongful. Hence when a plaint [complaint] of nuisance is made, we must ask what harm is done and see whether it is harmful and wrongful. If so, it must be removed; if not wrongful though harmful, it must be upheld.' See also D Ibbetson, A Historical Introduction to the Law of Obligations (OUP, 1999), pp 98-106.

${ }^{211}$ Ibid, 'The nuisances which destroy servitudes completely or, at the least, keep them from being used effectively, are infinite...'. See also Fifoot, n 150, pp 5-9.

${ }^{212} \mathrm{Ibid}$, 'One may have this servitude, that is, the right of conducting water from another's land and over another's land to his own land in order to irrigate his field, or to provide some other benefit; he ought not then to be completely prevented from conducting it, or kept from conducting it conveniently or in the proper way, according to the constitution of the servitude, as where, [when] he ought to conduct it at all times, the other only permits him to conduct it at some time, [or] if at certain times, not at any time. And if he does not permit him to conduct it in the quantity due, [or] to scour the channel, by which the flow of water is impeded and the tenements of neighbours flooded. In all these cases a disseisin is done the neighbour and he is protected [by the writ 'why he diverted a watercourse to the nuisance of his free tenement]...'

${ }^{213} \mathrm{Ibid}$, 'If one has the servitude of pasturing in another's land, he is entitled to free ingress and egress. If he whose land it is does something to his means of egress, so that he can hardly enter at all, or only with greater inconvenience, as where he builds a wall, a bank or a hedge, he commits a wrongful nuisance. What is thus done may at once be undone and demolished, even without a writ, if action is taken while the deed is still fresh; after time has passed, however, a writ will be necessary.'

${ }^{214} \mathrm{Ibid}$, 'if the right of going over another's land is granted and the road is obstructed in some way or narrowed, so that it may not be traversed at all, or only with difficulty.'

${ }^{215} \mathrm{Ibid}$, 'One may have common with another [in many ways], a right of digging just as a right of pasturing, that he may dig silver and gold, tin, chalk, stone, sand and the like in another's land. Similarly a right of hunting and fishing, drinking and drawing water and many others, infinite in number, with their appurtenances, that is with free access and departure, just as free and adequate entry and exit are appurtenant to common of pasture.'

${ }^{216}$ Ibid, p 190. 
every disseisin is harmful (nocet), by it the nuisance may be removed and damages restored to the plaintiff, both for the disseisin of his tenement and for the nuisance..${ }^{217}$

That said, the assize of novel disseisin was more limited than the assize of nuisance ${ }^{218}$ since it was restricted to the freehold of the complainant and not to adjacent land ${ }^{219}$ - which was why bringing a proceeding according to the latter was used when the nuisance came from one land to land. ${ }^{220}$ Bracton also drew a distinction between a private and a public (common) one, stating:

there may be a wrongful nuisance because of the common and public welfare, [nocumentum iniuriosum propter communem] which would not be such because of the private welfare, as where one having lands on both sides of a stream builds a fishery or pond, when his land is in every way free and under no obligation to neighbouring land, below or above; by so doing, though he causes damage to his neighbours, he commits no injuria; but nevertheless, what must be upheld [because of the private] may be demolished because of the public welfare, which is preferred to the private. ${ }^{221}$

Bracton also noted that things wrongfully erected to the nuisance of another might be demolished immediately and without delay. ${ }^{222} \mathrm{He}$ then cited the legal forms of writs for ordering a person to permit another to have a right of way for fishing, for a market etc. ${ }^{223}$ Bracton did not deal with nuisance in the criminal context and - in particular - with the sheriff's tourn and the court leet. ${ }^{24}$ However, with regard to the Eyre of justices, he noted matters which the jury considered (the Articles of the Eyre or Capitula Itineris) included:

Of purprestures made against the king, whether on land or in the sea or in fresh water, whether within a liberty or without or elsewhere, no matter where. 25

This wording referred to any encroachments on land and, thus, following Glanvill (see 4), included the king's highway. ${ }^{226}$ It also referred to rivers and the sea (though, probably, not the high sea). ${ }^{227}$ Why it was so important (to Bracton) to punish these purprestures (encroachments) was also clear:

\footnotetext{
${ }^{217}$ Ibid. J Reeves, History of the English Law (1787), vol 1, p 344 'a nuisance, being an injury to a freehold, was considered in the nature of a disseisin, and like that might be redressed by an assize; so also, like that, it might, flagrante facto, be removed by the party injured, without any ceremony of application to the law: but after the party had laid by, he had, as in the case of a disseisin, no redress but by writ.' See also Chew, n 152, p xii 'Bracton...mentioned the assize of nuisance by name for the first time. He explained that no one might complain of nuisances unless he was a freeholder, so that the assize was denied to any who held only for a term of years. Further, the nuisance must both have caused damage and be of a kind condemned by the law. He also emphasised that the tenement in question must be viewed.'

${ }^{218}$ Blackstone, $\mathrm{n}$ 47, vol 3, p 221 'An assize of nusance is a writ, wherein it is stated that the party injured complains of some particular fact done, ad nocumentum liberi tenementi sui, and therefore commanding the sheriff to summon an assize, that is, a jury, and view the premises, and have them at the next commission of assizes, that justice may be done therein: and, if the assize is found for the plaintiff, he shall have judgment of two things: 1 . To have the nusance abated; and 2 To recover damages. Formerly an assise of nusance only lay against the very wrongddoer himself who levied, or did, the nusance; and did not lie against any person to whom he had aliened the tenements, whereon the nusance was situated. This was the immediate reason for making the equitable provision in statute Westm[inster] 213 Edw $1 \mathrm{c} 24$ [Statute of Westminster 1285, c 24] for granting a similar writ, in casu consimili, where no former precedent was to be found.' Holdsworth, n 59, (5th ed, 1942), vol 3, p 11 'The novel disseisin was directed to secure an undisturbed possession: the assize of nuisance to secure its free enjoyment' cited in Rimmington [2006] 1 AC 459 per Lord Bingham at $\mathrm{p} 467$.

${ }^{219} \mathrm{P} \& \mathrm{M}, \mathrm{n} 20$, vol 2, p 53 'To meet that troubling of possession which is caused by nuisances as distinguished from trespasses, that is, by things that are erected, made, or done, not on the soil possessed by the complainant but on neighbouring soil, there has all along been an 'assize of nuisance' which is a supplement for the novel disseisin.' See also Reeves, n 217, vol 1, p 345-6, vol 3, pp 27-8.

${ }^{220}$ Fleta, $\mathrm{n} 26$, vol 89, p 116 'the... assize [of novel disseisin] does not include an assize of nuisance done in another's land. It is better therefore [to proceed] by an assize of nuisance by which both can be determined because the assize of nuisance extends to the land of another...' FH Newark, The Boundaries of Nuisance (1949) LQR, vol 65, pp 481-2 'Nuisance could never be committed on the [P's] land: an act done on the [P's] land would be disseisin or trespass according to the circumstances.' Fifoot, $\mathrm{n} 150, \mathrm{n} 9$ 'If the wrongful act done upon the [P's] land, novel disseisin was appropriate; if upon the [D's] land it was more remote from the conception of disseisin, and the assize of nuisance was to be brought. Acts done partly on the one land and partly on the other called strictly for both remedies, but for convenience Bracton allowed the $[\mathrm{P}]$ to confine himself to the assize of nuisance.'

${ }^{221}$ Bracton, n 24, pp 190-1. See also Spencer, n 3, p 58.

${ }^{222}$ Ibid, p 192 'Things so erected [or destroyed or demolished] to the wrongful nuisance [of another] may be immediately demolished and thrown down [or re-erected and restored] while the misdeed is still fresh, as in the case of other disseisins, if the plaintiff is able to do so. If not, recourse must be had to him who safeguards rights; he will have his remedy by this writ.'

${ }^{223}$ Ibid, pp 193-4.

${ }^{224}$ Hearnshaw, n 134, p 29 'Bracton...is as silent as Glanvill concerning both the sheriff's tourn and the nascent leet jurisdiction of his time.'

${ }^{225}$ Bracton, n 24, pp 330-1. See also Capitula Itineris, Statutes of the Realm (1814), vol 1, p 233.

${ }^{226}$ See also Bracton, $\mathrm{n} 24$, vol 3, pp 60-1 'It is clear that a boundary between neighbours, which divides demesnes and distinguishes the limits of lands, may be of many kinds, as, in the first place, the king's highway, which cannot be common between neighbours nor the property of anyone except the lord king. It is a quasi-sacred thing, and he who occupies any part thereof, by exceeding the limits and boundaries of his land, is said to have committed a purpresture upon the king. The same may also be said of a military road which may be
} 
- Highways and riverways were intimately linked to boundaries. ${ }^{228}$ Thus, altering the road or river (including banks (balks)) - as well as other boundary markers - would give rise to disputes and (likely) to breaches of the peace arising from physical violence;

- It may also be noted that Bracton treated the 'king's highway' by this time not as owned by the king per se, but by the public (the common property of all). ${ }^{229}$

\section{In conclusion, Bracton categorised nuisances into private and common (public) ones.}

\section{(b) Eyres of Justices}

In their Eyres, the justices suppressed encroachments on the king's land - including his highway. ${ }^{230}$ Thus, pursuant to an eyre in London in 1246, Royal justices walked the streets of the City to note any obstructions (purprestures) on the king's highway. ${ }^{231}$ The judges ordered their forfeiture (or alteration) or - in some cases payment of a rent in lieu. Examples are as follows:

- 'A forge stands in the middle of the king's highway opposite the New Temple...Let it be taken into the king's hand.'.'232

- $\quad$ The step of the cellar of William Le Fort at Smithfield contains [projects] in the king's highway of the field of Smithfield $5 \mathrm{ft}$. He is to give $6 \mathrm{~d}$ yearly to the king.'; ; 233

- 'William of Fleet built a solar at the Bar of Smithfield to the nuisance [ad nocumentum] of passers-by. Richard Saler built another to the same nuisance...They are to be in mercy and the purprestures are to be amended. ${ }^{234}$

Thus, from these Eyres, it is clear that obstruction to the highway was punished as a criminal offence (as it had been from early times, stretbreche). The rationale was that such an obstruction was a 'nuisance' to passers-by (the public). However, it was not asserted that the rationale was, itself, the crime. That is, there was no assertion that there was a crime of public nuisance at common law. Reference may also be made to the Berkshire Eyre of $1248^{235}$ and Wiltshire Eyre of $1268^{236}$ where obstructions to the highway were punished.

called public and leads to the sea and the ports, and sometimes to markets. A balk [bank] is made with the consent of neighbours, and out of their lands, and is common between those from whose lands it has been made up; hence the tenement so constructed is said to be common between them, so that no one owns it by himself but in common. And so if by common consent earth out of a common tenement is made into a bank or wall. A boundary (divisa) is so called because it divides lands and tenements. Running water is called a boundary only so long as it holds its right course; when it changes its bed it ceases to be a boundary. A boundary may also be a boundary stone or a wooden stake, and all are the common property of the neighbours, not of any one of them...'

${ }^{227}$ The assertion of Crown jurisdiction over the high seas really only commenced in the reign of Edward III (1327-77), see GS McBain, The Strange Death of the Law Merchant (2016) International Law Research, vol 5, no 1, p 97 (Fasciculus de Superioritate Maris).

${ }^{228}$ See n 226.

${ }^{229}$ Bracton, n 24, vol 3, p $130^{\prime}$ 'There is also a tenement which is, so to speak, common to a greater extent, that is, which is not the property of any individual person by himself, nor in common, nor the property of a universitas by itself, but the common property of all, as the king's highway, the shore of the sea.'

${ }^{230}$ Ibid, p 136, article 31 of the Eyre. 'Of purprestures made upon the king whether by land or water or in the liberty of the City. The City answered that they knew of no purpresture made on the king concerning the liberty but they do not wish to enquire of other purprestures except by each alderman and his ward and thus it had been done. But the justices not content with the inquest walked around the City with the mayor and the citizens to inspect and enquire concerning all the different purpresutures which are noted....'

${ }^{231}$ HM Chew \& M Weinbaum (eds), The London Eyre of 1244 (London Record Society, 1970), pp 136-53 (Special Inquest into Purprestures, January 1246). See also Brooke, n 78, pp 163-6. Chew, n 152, p xxvii 'The normal procedure at such sessions...was to amerce anyone who made a purpresture but to allow him or his heirs or assigns to rent it from the king for a fixed annual rent provided the dozens (duodene) of the ward should agree that it was not a nuisance to the neighbours but if it was not so agreed, the sheriffs were to throw it down.' It may be noted that Eyres in London ended in 1351 and the died out generally in the latter part of the 14th century.

${ }^{232}$ Ibid, p 137.

${ }^{233}$ Ibid, pp 138-9.

${ }^{234}$ Ibid, 139. Bailey, n 2, (solarium) '[in ancient writings] an upper room or garret, which in some part of England is still called a solar.' See also Munimenta, n 65, vol 3, p 359 (an upper room).

${ }^{235}$ The Roll and Writ File of the Berkshire Eyre of 1248, SS, vol 90, p 321 'The jurors present that [X] has made a purpresture on the king on the royal highway in Compton, so [he is] in mercy. The sheriff is ordered to have it remedied.'

${ }^{236}$ B Farr, Crown Pleas of the Wiltshire Eyre 1268 (2012), p 33 'Concerning purprestures, they [the jurors] say that [X] has diverted the course of a river towards his own mill and made it closer to the king's pond than it used to be, to the detriment of the king's mill.' Ibid, $\mathrm{p} 48$ 'Concerning purprestures, they say that the prior of St Swithun, Winchester, has made a purpresture at Bushton to the extent of half an acre, in that he has occupied a site called Kingsbridge which used to answer to the king for $6 \mathrm{~d}$ a year, and the sheriffs were accustomed to hold their hundred courts there.' Ibid, p 64 'Concerning purprestures, they say that [X], who holds the manor of Melksham from the king, has raised a bank in Melksham township upon the king's highway, and in length and breadth it contains 1 perch of land. Again, the abbess of 


\section{In conclusion, the Eyres of Justices punished obstructions to public highways and waterways.}

\section{(c) Statute of Wales 1284 - Sheriff's Tourn}

Apart from obstructions to the highway, other nuisances would have been punished. This would have been in the sheriff's tourn or court leet. Whether the former existed in Anglo-Saxon times is unclear (see 3(d)). It may have arisen at the time of the Assize of Clarendon 1166 - being a bi-annual perambulation required to be made by the sheriff through the hundred over which he had jurisdiction, in order to ensure that the requisite oaths of frankpledge were given. ${ }^{237}$ This court were not discussed by Glanvill in his text of c. 1189 (see 5) nor by Bracton in his text of 1240 (see 8).

- As to what jurisdiction the sheriff's tourn had over criminal matters - and what nuisances it dealt with - insight is provided in the Statute of Wales 1284. This legislation ${ }^{238}$ applied the sheriff's tourn to Wales ${ }^{239}$ and it is useful since it referred to the articles of the tourn ${ }^{240}$ which set out the jurisdiction of the sheriff. That is, what matters he might deal with.

As well as certain serious crimes ${ }^{241}$ - which the sheriff could inquire of but not judge ${ }^{242}$ - and certain Crown franchises claimed or usurped (e.g. treasure trove), the sheriff's jurisdiction included the non-observance of the Assizes of Bread, Ale and of Measures. ${ }^{243}$ However, these - even if they could be categorised as 'nuisances' were statutory. Thus, they cannot be treated as common law nuisances. The Statute of Wales also referred to the following:

Of turning [diverting] water courses. ${ }^{244}$ Of hindrance, restraint, and narrowing of the highway. Of walls, houses, gates, ditches, and marlpits ${ }^{245}$ raised and made near unto the public highway, to the nuisance of the same way, and to the danger of passengers; and of them that raise and make the same.

These comprised obstructions of the public highway (or waterwater). As previously noted, these had long been punished - as stretbreche in the case of the highway (see 4(b)). However, referring to them in the Act, the effect was to make such a crime statutory (in the eyes of later legal writers) even if it had been a common law crime prior to this.

\section{In conclusion, the sheriff's tourn punished obstructions to public highways and waterways.}

\section{BRITTON (c. 1290) \& FLETA (c. 1290)}

\section{(a) Britton}

Britton (writing c. 1290) - like Bracton - considered the law on nuisance in some detail. ${ }^{246}$ He noted that, civilly, nuisances could be prosecuted by means of assizes of disseisin ${ }^{247}$ and of nuisance. ${ }^{248}$ The sheriff could also issue a writ of justicies to deal with obstructions to the highway. Thus:

Lacock has made a purpresture in Melksham forest by enclosing 40 acres within the king's forest, to the detriment of the whole liberty of Melksham, and they do not know by what warrant. Later the abbess's attorney comes and shows the king's charter whereby the king granted to the abbess and her nuns etc., and to their successors, [the right] at their will to enclose that place with a bank and a hedge.' Ibid, $\mathrm{p} 108$ 'Concerning purprestures, they say that $[\mathrm{X}]$ holds a purpresture at 'Raenildewelle' which he took from Richard, constable of John de Mycegros, and he pays the king $1 \mathrm{~d}$. It is a nuisance to his neighbours.'

${ }^{237}$ See n 202.

${ }^{238}$ Statutum Wallie 12 Edw 1(1284) c 4. See Statutes of the Realm (1814), vol 1, p 55. See also Hearnshaw, n 134, pp 46-8.

${ }^{239}$ Hearnshaw, n 134, p 48 'Edward I did not attempt to introduce this alien system of mutual guarantee into Wales.'

${ }^{240} \mathrm{Ibid}, \mathrm{p} 46$ 'The sheriff is directed to enquiry on the oaths of twelve or more discreet and respectable free-holders concerning a long series of capitula or articles of the tourn.'

${ }^{241}$ Ibid 'Of traitors to our lord the king and the realm, the queen, and her children, and their abettors. Of thieves, manslayers, robbers, murderers, burners...etc.' See also Hearnshaw, n 134, pp 46-7.

${ }^{242}$ The right to do so had been take away from the sheriff by Magna Carta (1215), ch 24. This was due to abuse. See also Kechnie, $\mathrm{n} 183$, $\mathrm{p}$ 344.

243 'of non-observance of the Assize of Bread and Beer, and of breakers thereof. Of unlawful bushels, gallons, and other measures. Of unlawful yards and weights, and them that sell therewith.'

${ }^{244}$ OED, $n 4$ (watercourse) '1. A stream of water, a river or brook....2. The bed or channel of a river or stream. 3 . The flow of water. 4 . The fairway or width of water-surface under a bridge.'

${ }^{245}$ Ibid (marlpits) 'A kind of soil consisting principally of clay mixed with carbonate of lime, forming a loose unconsolidated mass, valuable as a fertiliser.' 
There are...some nuisances which sheriffs are authorised to redress, as are also our hundreders, and many other freemen, who have view of frankpledge for the common benefit; ${ }^{249}$ as in the case of a [high] way being stopped, in order that passengers may not be too long deprived of their way, and in the case of several other nusances. ${ }^{250}$

As to nuisance in the criminal context, Britton referred to the sheriff's tourn:

There are some articles concerning our Crown and the breach of our peace of which sheriffs may hold plea at other times than on the county days, and in a different place from that where the pleas of the county are held. These pleas are called tourns of the sheriff, who ought to hold them twice in the year, within every hundred of his county. ${ }^{251}$

At the tourn, 12 jurors (appointed from all the freemen of the hundred and other landholders) gave their verdict on the articles of the tourn presented to them. ${ }^{252}$ The articles of the tourn which Britton cited were similar to those in the Statute of Wales 1284 (see 8(c)) though they also included frankpledge (in Wales frankpledge did not apply which it why it was not mentioned in the Statute of Wales 1284). In respect of public nuisances, these articles referred to:

waters stopped or narrowed or turned from their course; of roads stopped, narrowed, or turned; of walls, houses, gates, marl-pits, ditches, or other nuisances raised or made in any common way to the annoyance of the same way and to the danger of passengers...of the king's highways not widened ${ }^{253} \ldots$ of bridges and highways broken, and who ought to repair them... ${ }^{254}$

\section{Britton (like Bracton) distinguished between civil and criminal nuisance. For the latter, the nuisance had to be injurious to the 'commune des gentz'. That is, to the public.}

\section{(b) Fleta (c. 1290) - Courts Leet}

Fleta (writing c. 1290) ${ }^{255}$ stated:

The king also has his court in the turns of the sheriff and the views of frankpledge of the hundredmen, which are made twice a year and no oftener ...And view of frankpledge are to be made at the same Michaelmas term without hindrance, that is to say, each is to have the franchises which he had by rightful title or was accustomed to have in the time of king Henry II [1154-89] or which he has properly acquired since. ${ }^{256}$

\footnotetext{
${ }^{246}$ Britton, n 25, p 316 'There still remain other kinds of disseisins, which are to be remedied by this assize, and which arise from tortious nusances done by one neighbour to another; as when a watercourse is wrongfully diverted or stopped, to the annoyance of the neighbour's freehold.'

${ }^{247}$ Ibid, p 222 (disseisins), especially p 227 'There are several nuisances, which may be prosecuted by this assize, and yet not to recover a freehold, but to remove wrongful nuisances, as if a watercourse or way is wrongfully turned or enlarged or straightened, or a ditch, house, wall, hedge, or market wrongfully set up, or a pond wrongfully raised or lowered to the annoyance of his neighbour. Some nuisances however are determinable by sheriffs in county courts and not by assizes, as in the case of encroachments of curtilage upon common weirs, watering-places for cattle, erection of gates, folds, cowhouses, windmills, ovens, or sheepcotes.'

${ }^{248}$ Ibid, p 316 'There still remain other kinds of disseisins, which are to be remedied by this assize, and which arise from tortious nusances done by one neighbour to another; as when a watercourse is wrongfully diverted or stopped, to the annoyance of the neighbour's freehold.'

${ }^{249}$ A note in the manuscript states 'It should be known that the sheriff ought not to redress any nuisance presented at his tourn, if it be not wrongful and injurious to the community (a commune des gentz). For nuisance done to a single person shall be redressed by a single suit and not otherwise.'

${ }^{250}$ Ibid, p 316. See also Fleta, n 26, p 113, 'redress sometimes pertains to the sheriff, as in the case of the obstruction of a road, by a writ of justicies on behalf of the public welfare lest travellers should be for long prevented from going on their journeys, for this would be a public mischief.' Ibid, p 116 'A nuisance can be against the public welfare, which always and in every case is to be given preference over private welfare.'

${ }^{251}$ Ibid, p 146. Britton continued 'And that which before the sheriff is called the sheriff's tourn, is in the court of a freeman and in franchises, and in our hundreds, called view of frankpledge, where a more special inquiry is made concerning those who are not in any tithing, than is done in the sheriff's tourn.'

${ }^{252}$ Ibid, p 147 'let the sheriff cause twelve of the most sage, lawful, and sufficient men out of the whole hundred to be chosen, and to swear they will present the truth of the articles hereinafter mentioned...of waters stopped or narrowed or turned from their course; of roads stopped, narrowed, or turned; of walls, houses, gates, marl-pits, ditches, or other nuisances raised or made in any common way to the annoyance of the same way and to the danger of passengers...of bridges and highways broken, and who ought to repair them...' (italics supplied)

${ }^{253}$ The Statute of Winchester 1285 (also called the Statute of Winton) 13 Edw 1 st 2 c 5 provided for the widening of the highways 'highways leading from one market town to another shall be enlarged whereas [bushes woods] or dykes be, so that there be neither dyke [tree] nor bush, whereby a man may lurk to do hurt, within two hundred foot of the other side of the way.' See also Fleta, n 26 , vol 72 , p 62.

${ }^{254}$ Britton, n 25, p 148

${ }^{255}$ Fleta, n 26, vol 72.

${ }^{256}$ Ibid, p 174-5.
} 
The reference to the 'Views (Assemblies) of Frankpledge' are to the courts leet. As previously noted, it is uncertain whether courts leet existed in Anglo-Saxon times (see 3(d)) although it is asserted that they did, being the assembly which gathered in which males over 12 gave their oath of frankpledge. If not, it seems likely they existed by the 12th century - being the franchise of the sheriff's tourn to lords of the manor (and other important dignatories). Pollock and Maitland stated:

Offences punished upon presentment in the local courts. The process of presentment had been introduced into the local courts by Henry II [1154-89], but only, so it seems, for the purpose of collecting accusations of grave offences. However, in course of time, many other presentments were made there. A general understanding seems to have allowed the sheriff in his 'turns' and the lords of franchises in their 'leets' to demand presentments about any matter that concerned the king's rights or his peace. 'Articles of the Turn' or 'Articles of the View of Frankpledge' were drawn up. The different copies which have come down to us, though they bear one general character, differ in many details. They leave us doubting whether any of them had received solemn sanction from the central power. ${ }^{257} \ldots$ [The articles] ask for charges of minor offences which are dealt with on the spot by a summary procedure leading to amercements. These offences are most[ly] miscellaneous... There are nuisances, especially the straitening of highways - these can be summarily redressed or 'addressed.' There are those never ceasing breaches of the assizes of bread and beer. ${ }^{258}$

As to the 'nuisances, especially the straitening of highways' which Pollock and Maitland referred to, Fleta indicated that these included:

boundaries broken down, removed or decreased. Also concerning waters diverted from their courses or stopped. Also concerning dikes, walls, causeys [i.e causeways], ${ }^{259}$ ponds, and the like which are erected, knocked down or set up to the nuisance [of others]. Also concerning roads and paths wrongfully stopped or narrowed.... ${ }^{260}$

Courts leet had jurisdiction over the obstructions to the highway (and waterways) by way of franchise. ${ }^{261}$ Thus, the relevant lord of the manor with the franchise to hold a court leet, collected the fines imposed for the commission of this minor crime. The general requirement was that of restoration with the chief pledges of the tithing (the precursor to the police constable) being the one required to ensure the same 'without delay.' ${ }^{262}$

\section{In conclusion, courts leet punished obstructions of public highways and waterways. They had the jurisdiction (authority) to do so by way of Crown franchise, being the franchise of the sheriff's tourn.}

\section{PUBLIC NUISANCE BY 1290}

The legal position in respect of the crime of public nuisance by 1290 may be summarised:

- $\quad$ Anglo-Saxon Times. Anglo-Saxon law did not distinguish between civil or criminal law and the basic system was the payment of a penalty (bodily or monetary) for certain acts. There appears to be no express concept of (or reference to) nuisance as such under Anglo-Saxon law. However, if the Laws of Edward the Confessor (redacted c. 1140) correctly reflect Anglo-Saxon law, then obstruction (purpresture) to a highway or waterway that was: (a) Royal (there were, probably, only 4 Royal roads at this time); or (b) public, was punishable in Anglo-Saxon times. The only other 'public' nuisance which may be said to have existed in Anglo-Saxon times seems to have been

\footnotetext{
${ }^{257} \mathrm{P} \& \mathrm{M}$, in a fn stated 'The set given in the Statutum Walliae (Stat. i.57)[Statute of Wales 1284,see 8(c)] seem to be the only one which comes to us from an authoritative source. See also the apocryphal Statute de Visu Franciplegii (Stat 1 246)[Statute of the View of Frankpledge of uncertain date].' Although P \& M may have thought the Statute of Frankpledge apocryphal, both legal writers and the Star Chamber appears to have accepted it, see Baildon, n 134, p 350.

${ }^{258}$ P \& M, n 20, vol 2, p 520.

${ }^{259}$ Johnson (writing in 1755), n 4 (causey) 'chauffee. French. This word by a false notion of its etymology, has been lately written causeway.' OED, $\mathrm{n} 4$ (causey) '1. A mound, embankment, or dam, to retain the water of a river or pond. 2. A raised way formed on a mound, across a hollow esp. low wet ground, a bog, marsh, lake, arm of the sea etc. a raised footway by the side of a carriage road liable to be submerged in wet weather. More fully called causeyway now causeway; causey being now lessed used.'

${ }^{260}$ Fleta, n 26, vol 72, p 176. The position in the sheriff's tourn was not different. Thus, Fleta, p 176, referred to 'if [inquiries are made] in the sheriff's turns or the hundredmen's views, then the articles are as follows...Concerning the concealment or alienation of the king's rights on land or sea, by whom they were alienated or concealed, and for how long...Also concerning purprestures made upon [the lands of] the king or [other] lord...Also concerning the breaking of bridges and causeys.'

${ }^{261}$ See also Fleta, n 24, vol 72, p 101 'There are certain barons who have the special franchises set out below by grant from kings of old time... The franchises in question are these, namely...forestall, obstructing the highway or impeding the passage and driving of animals.' The wording in italics would seem to be a reference to stretbreche, see also text to 145 .

${ }^{262}$ Ibid, p 178 'When it happens that anyone is indicted of removing boundaries or obstructing roads or diverting water-courses and suchlike lesser wrongs committed within a year and a day and he is present, let him answer at once if he wishes, and if he refuses to do so or is absent, let the chief pledges be ordered to restore, without delay, to its proper state what was wrongfully altered.'
} 
prostitution. Statute law (Anglo-Saxon dooms) provided that prostitutes were to be driven from the land (outlawed), which presumes the suppression of any brothel;

- $\quad$ Glanvill (1189). The first legal text referred to purprestures (encroachments) on the 'property of the king' - which included a Royal highway, waterway or demesne (royal city, town, port etc) - and, that ' whenever anything is done to the nuisance of a royal tenement or way or city, the resulting plea belongs to the...king.' Glanvill included public highways and waterways in his description - likely, following the Laws of Edward the Confessor (see above). Thus, this was no different to the Anglo-Saxon position - save that the number of roads and other Royal property had been hugely augmented by William I (1066-87). By 1166, certain brothels were permitted in Southwark (if not before);

- London. Being the major town, with a population of (perhaps) 18,000 by 1066 , public nuisances would most likely occur here. Brothels were regulated by an Ordinance (a form of statute) in 1166 and the Assize of Building 1189 (a form of statute) dealt with nuisances arising from building encroachments on the property of others. From 1197, other Assizes regulated matters such as bread, ale, wine, weights and measures - as well as punished infractions. Magna Carta 1215 prohibited another form of nuisance (kidels, i.e. fish weirs) in rivers. Finally, many other nuisances were regulated and punished by Ordinances from the time of Edward I (1272-85)(this is discussed in 11). Prior to this they were (probably) punished criminally as 'deceites' (later, called the crime of cheat);

- Wardmote. The court which punished minor crimes in London was the wardmote (ward assembly). It is likely London was divided into 24 wards (with an alderman at their head) by 1111 and that (probably) the wardmotes also existed then. Indeed, it is possible that such courts existed long before, since - in Anglo-Saxon times - the law of frankpledge (the pledge of freemen) required men over the age of 12, in assembly, to swear an oath to keep the peace before a Crown official (usually the reeve). This annual View (Review) of Frankpledge, in London, may have been conducted before an assembly which later became called the wardmote;

- $\quad$ Sheriff's Tourn. In the shires, the View of Frankpledge was conducted before the shire-reeve (sheriff). From the Assize of Clarendon 1166 (if not before) sheriffs were required to make a perambulation twice a year of their hundred in which they conducted a Review of Frankpledge. ${ }^{263}$ This became known as the Sheriff's Tourn (Turn). As well as dealing with frankpledge, this court dealt with minor crimes such as breaches of the Assizes and public nuisances;

- $\quad$ Court Leet. These courts were also called the View of Frankpledge. Thus, they probably existed in Anglo-Saxon times (and, in London, were later called wardmotes). They were the franchised version of the Sheriff's tourn franchised out to lords of the manor (and other dignatories). Even if this did not occur in Anglo-Saxon times, it seems likely that it started to occur by the Assize of Clarendon 1166;

- $\quad$ Articles. The articles of the wardmotes, sheriff's tourn and courts leet had a common source. They specified what crimes lay within the jurisdiction of these courts. Given the importance of London, it is reasonable to suppose the articles of the wardmote were the template for those of the sheriff's tourn and courts leet;

- $\quad$ Position by 1290. Bracton (in 1240) distinguished civil from criminal nuisance. The later was injury contrary to the 'common welfare' (nocumentum iniuriosum propter communem). However, he did not discuss wardmotes, the sheriff's tourn or the court leet. Nor, how criminal nuisance was punished. For their part, Britton (c. 1290) and Fleta (c. 1290) mentioned the sheriff's tourn and court leet. They also referred to the articles of the sheriff's tourn (specified in the Statute of Wales 1284) and to the articles of the court leet.

In light of this, what 'public nuisances' were punished by the criminal law by 1290? The answer is 'few' and that these were pre-dominantly statutory, not common law. These fall into four main categories:

- $\quad$ Brothels. Anglo-Saxon law provided for prostitutes to be driven from the land. This presumes the suppression of brothels. By 1166, certain brothels were licensed in Southwark (probably, they had been tolerated prior to that date). Given this, all others in the City would have been suppressed. Thus, the common law crime of maintaining a brothel (as a disorderly house was then called) would have arisen. However, this was a distinct common law crime and public nuisance as such did not have to be proved - albeit, the rationale for suppressing brothels (originally, religious) was, later, to be on the basis they were a nuisance to the community (a public nuisance);

\footnotetext{
${ }^{263}$ This obligation of frankpledge may have fallen into abeyance with all the turmoil of the Norman Conquest and aftermath. However, in 1195, a proclamation of Archbishop Hubert of Canterbury (who was also justiciary of all England) required that 'all subjects of the kingdom of England, shall, to the best of their power, keep the peace of their lord the king' and that 'knights who are appointed for that purpose, shall make all persons of their respective districts, of the age of fifteen years [sic] and upwards, appear before them, and shall make them swear that they will keep the peace.' This re-invigorated the view of frankpledge (as well as the hue and cry). For the form of the proclamation see HT Riley (trans), The Annals of Roger of Hoveden, vol 2, pt 2 AD 1192 to 1201 (facsimile rep by Llanerch Publishers), pp 367-8. See also McBain, n 70, p 174, n 139.
} 
- $\quad$ Assizes of Bread, Ale etc. These were all statutory, and public nuisance as such did not have to be proved. Further, while the rationale for punishing infractions was, later, to be that they comprised a public nuisance, they were punished no different to any other crime. That is, if not suppressed they would, likely, give rise to a breach of the peace (i.e, violence). These Assizes are further discussed below (see 11);

- $\quad$ Obstructing the Highway. It seems likely that persons - from Anglo-Saxon times - were punished for obstructing Royal and public highways and waterways. Further, there was a specific crime as early as c. 1113 (if not long before) - that of stretbreche (street breach). By the Statute of Wales 1284 the nature of the crime was more closely defined since it referred (as did the articles of the court leet) to: (a) boundaries broken down, removed or decreased; (b) waters diverted from their courses or stopped; (c) dikes, walls, causeways, ponds, and the like erected, knocked down or set up to the nuisance of others; (d) roads and paths wrongfully stopped or narrowed. This specification of the jurisdiction of the sheriff's tourn (and court leet), in time, became the definition of the crime of obstructing the king's (public) highway - with the highway itself 'expanding' as more roads were created.

None of the above can be regarded a distinct common law crime of public nuisance since: (a) managing a brothel (disorderly houses) was a distinct common law crime; (b) Assizes of Bread etc were statutory; (c) obstructing the public highway (and waterway) - albeit it may have been common law crime - was, effectively, made statutory by the Statute of Wales 1284 . This leaves the fourth category:

- $\quad$ Public Nuisances in the City. Later legal writers did not refer to the early law on the City. Doubtless, because it was difficult to access. However, a review indicates there were (many) other nuisances affecting the public in the City which the criminal law punished - as may be expected since, otherwise, such a close concentration of people without some sort of regulation would produce chaos. Other major towns in England would have been the same. Probably, most of these minor crimes were punished as 'deceites' at common law. However, by the reign of Edward I (1282-1307) - it also seems clear that these public nuisances in the City became statutory (with obsolete common law ones being allowed to lapse).

In conclusion, by 1290, there was no (generic) common law crime of public nuisance. True, there were nuisances punished by the criminal law. However, these were statutory nuisances or distinct crimes (such as managing a disorderly house). Those prevailing in London are now considered.

\section{LONDON - c. 1290}

Prior to considering in detail various City regulations on nuisances in this period, the following general observations may be made:

- $\quad$ Assize . As previously noted, Richard I (1189-99) promulgated an Assize of Measures in 1197 and king John (1199-2016) promulgated an Assize of Wine in 1199. Further, Magna Carta 1215 contained an Assize of Cloth as well as specified measures for wine, ale and corn. Whether there were other Assizes in the period 1197-1266 is unclear. However, in the reign of Henry III (1216-72), there were enacted, c. 1266, the Assize of Bread and Ale, the Assize of Weights and Measures and the Assize of the Pillory. The latter was designed to punish infractions of these other Assizes as well as the sale of unwholesome food and forestalling. ${ }^{264}$ The usual punishment for offences covered by these Assizes was a fine for the first offence and the pillory (or tumbrel) for repeat offences. However, these offences were statutory. Thus, they cannot, be treated as common law public nuisances - although some later writers seem to have treated them as such; ${ }^{265}$

- $\quad$ Ordinances. In c. 1277, 1281 and 1285, Ordinances (also referred to as 'Assizes', 'Statutes' and 'Articles') were promulgated by Edward I (1272-1307) to regulate the administration of the City. Those of c. 1285 would have been promulgated when Edward I took the City back into his hand (which he did in the period 1285-98 when he appointed his own warden in place of the mayor) ${ }^{266}$ Many of these Ordinances dealt with nuisances and they imposed a fine or the pillory, for infractions. However, these offences were statutory since an Ordinance comprised a form of legislation, ${ }^{267}$ albeit it was more temporary than an Act and, like the later Proclamation, it was intended to be a declaration - and not an alteration - of the law. ${ }^{268}$ There is no suggestion in them that these

\footnotetext{
${ }^{264}$ See also text to $n 323$.

${ }^{265}$ Cf. Coke, n 43, vol 4, p 71. See also vol 4, pp 261-2.

${ }^{266}$ Liber Albus, n 64, pp 14-7.

${ }^{267}$ WR Anson, The Law and Custom of the Constitution (5th ed, 1922), pp 256-8 'The Ordinance is put forth in letters patent or charter and is not engrossed on the Statute Roll; it is an act of the king or of the king in council; it is temporary, and is revocable by the king or the king in council. The Statute is an act of the Crown, Lords and Commons; it is engrossed on the Statute Roll; it is meant to be a permanent addition to the law of the land; it can only be revoked by the same body that made it and in the same form.' Coke, $\mathrm{n} 43$, vol 4 , $\mathrm{p} 24$ 'The difference between an Act of Parliament and an ordinance in Parliament, is, for that the ordinance wants [lacks] the threefold consent, and is ordained by one or two of them.'

${ }^{268}$ Ordinances were replaced by proclamations. Anson, n 267, p 341 'Legislation by ordinance, which had been denounced at the end of the fourteenth century, disappeared during the fifteenth, but revived in the sixteenth in the form of legislation by royal proclamation.'
} 
Ordinances $1277-85$ contained wholly new material. Therefore, they may have been based on earlier Ordinances made in the reign of Henry III (1216-72) - or even before - now lost.

In short, the City - likely, from early times - punished many acts which comprised a nuisance (annoyance) to the general public. However, in the reign of Edward I (1272-1307) there was a concerted effort to place existing common law nuisances on a statutory footing. This was, doubtless, to clarify them and accord them a greater legal certainty. In so doing, other common law nuisances which might have existed in London were allowed to fade away, by not being placed in such legislation. These Ordinances are now considered.

\section{(a) City Ordinance - 1277}

The Letterbooks of the City of London, Letterbook A (1275-98) contains the following statement:

These are the Assizes of the City of London read by the mayor and reputable men, the second year of the mayoralty of Gregory [de Rokesle], Robert de Arraz and Ralph le Fevere being sheriffs [AD 1276-7], and the third year of the same mayoralty, Walter le Cornewaleys and John, son of John Adrian, sheriffs [AD 1277-8].

Gregory of Rokesley (in Kent) was a wealthy wool merchant and goldsmith. He served as lord mayor on eight occasions (from 1274-80 and, again, in 1284). The statement says that these Assizes were 'read' (that is, proclaimed) ${ }^{269}$ in 1277 and 1278 . I shall refer to them as the City Ordinance of 1277 . It contained various provisions (see App A), ${ }^{270}$ some of which deal with nuisances. For example, one provided that:

no one shall throw any filth in the highway, nor allow it to be raked in the time of rain, nor remove it so as to be a nuisance to the neighbours. (italics supplied)

Here, the reference to 'nuisance' was to the rationale for punishing the act. There is no evidence that a person was punishable for generic crime of 'public nuisance' (whether statutory or common law). Only for those infractions as listed.

\section{(b) City Ordinance - c. 1281}

The Liber Albus (1419) contains certain articles although the heading for them is to be found in the Liber Custumarum, which states:

These are the Articles, of ancient usage, as to the assize of bread, and of ale, and of other victuals, and as to various mysteries, in the City of London, that ought each year, after the feast of Saint Michael [29 September] to be proclaimed throughout the said City. ${ }^{271}$

It is unclear when these Articles (which I shall refer to as the City Ordinance of 1281) were promulgated. However, they may have been in 1281 , when Henry le Wallis was mayor. ${ }^{272}$ They commenced:

In the first place, that the peace of God and the peace of our Lord the King shall be well kept and maintained among denizens and strangers; and that the places and the lanes of the City shall be kept clear of all manner of annoyance, such as dung, rubbish, pigsties, and other annoyances, under heavy penalties.

The Ordinance of 1281was more extensive than that of 1277 and it covered a large variety of matters. viz. the
(a) sale of food; ${ }^{273}$
(b) holding of markets; ${ }^{274}$
(c) corn dealers; ${ }^{275}$

\footnotetext{
${ }^{269}$ Letterbook $A, \mathrm{n} 66, \mathrm{p} 215, \mathrm{n} 3$.

${ }^{270}$ Ibid, pp 215-9. I have merged some of the provisions (such as with regard to bread), and I have inserted titles, to assist with reading.

${ }^{271}$ Liber Albus, n 64, pp 228-44.

${ }^{272}$ Memoranda (1323-64), n 67, vol 1, p xvii (Ordinances drawn up by Henry le Galeys or Waleys (also called Henry le Wallis, mayor 1273, 81-83, 1298).

${ }^{273}$ Liber Albus, n 64, p 228 ' all manner of victuals that are sold by persons in Chepe [the present Cheapside and Cornhill], and elsewhere in the City, such as bread, cheese, poultry, fruit, hides and skins, onions and garlic, and all other small victuals, for sale as well by denizens as by strangers, shall stand mid-way between the kennels [i.e. gutters] of the streets, so as to be a nuisance to no one, under pain of forfeiture of the article.'

${ }^{274}$ Ibid, 'no market shall be held upon fair-days, as well for pots, pans, hutches [i.e. chests][and] coffers, as for other utensils of iron and of brass, save only at Cornhulls; and this to be mid-way between the kennels, so as not to be an annoyance to any one passing, under penalty of losing the article.'
} 
(d) butchers; ${ }^{276}$

(e) forestallers;

(f) strangers;

(g) rebellious persons;

(h) bakers, ${ }^{277}$

(i) measures;

(j) bakers;

(k) brewers, taverners and their measures;

(l) hostelers (ie. hotel keepers);

(m) strangers;

(n) brokers;

(o) citizens to be in scot and lot; ${ }^{278}$

(p) pigs; ${ }^{279}$

(q) barbers;

(r) regrators;

(s) corn dealers;

(t) penthouses (i.e. projections from a house); ${ }^{280}$

(u) Walbrook river and the king's highway; ${ }^{281}$

(v) apprentices;

(w) victuallers;

(x) corn-porters;

(y) cloths;

(z) lepers;

(aa) fish sellers; ${ }^{282}$

(bb) measures and balances;

(cc) prohibition on fencing schools;

(dd) butchers;

(ee) cleaning streets and lanes; ${ }^{283}$

(ff) prostitutes; ${ }^{284}$

(gg) regrators;

(hh) persons wandering by night (ie. nightwalkers); ${ }^{285}$

\footnotetext{
${ }^{275}$ Corn was a stable food and, thus, a vital necessity both for the population of the City and the people of England generally. Its regulation, to prevent the inflation of prices, was key, therefore.

${ }^{276}$ Liber Albus, n 64, p 230 'whereas some butchers do buy beasts of country folks, and as soon as they have the beasts in their houses kill them, and then at their own pleasure delay the peasants of their pay; or else tell them that they may take their beasts - It is provided, that the penalty which in such case is [specified] as to buyers and brokers of corn ordained, shall be incurred by such butchers as shall thereof be attainted.'
}

${ }^{277}$ e.g. p 231 'And that two loaves shall be made for one penny, and four loaves for one penny; and that no [loaf] shall be baked of bran. And that no baker shall sell bread before his oven, but [only] in the market of his lordship the king...And that each baker shall show his seal at each wardmote, that so it may be known.' Errant bakers were punished with the pillory. However, from 1258, justiciar Hugh Bigot ordered them to be punished with the tumbrel. In 1283 this was changed to the hurdle, which punishment was discontinued in the reign of Henry VI (1421-71). See Munimenta, n 65, vol 3, p 304.

${ }^{278}$ Generally, the distinction between freemen of the City (who obtained various privileges) and those not (foreigners) was that the former paid the City rates. See P Tucker, Law Courts and Lawyers in the City of London 1300-1500 (CUP, 2007), p 23.

${ }^{279}$ e.g. p 235 'no swine shall be found about the streets, or about the lanes in the city, or in the suburbs, or in the fosses [ditches] of the said city, from this time forward. And if swine shall be found in the places aforesaid, they may be killed by those by whom they shall be so found; and those who kill them, shall have them freely and clearly without any challenge thereof; or else the swine shall be brought back by him who owns it at the price of four pence. And he who shall wish to feed a pig, must feed it in his house.'

${ }^{280}$ e.g. p 237 'the penthouses and jettees [projections] of houses shall be so high that folks on horseback may ride beneath them. And that they shall be of the height of nine feet, at the very least; and that all others shall be forthwith re-arranged within forty days, under a penalty of forty shillings unto the use of the sheriffs. And that no stall shall project out [from the house] beyond the width of two feet and a half; and the same shall be moveable and flexible, for the convenience of the neighbours.'

${ }^{281} \mathrm{Ibid}, \mathrm{p} 237$ 'the watercourse of Walbroke [i.e. the Walbrook river which ran from Finsbury Moor to the Thames] and the highway of his lordship the king [king's highway] shall be kept clear, that so no dung or other filth be thrown therein, to the disturbance or annoyance of folks.' Chew, n 152, p xxx 'to keep the Walbrook flowing without obstruction or excessive filfth, was a task which greatly exercised the City authorities. Londoners stacked their firewood above it, built pig-sties and privies over it and otherwise encroached upon its course.'

${ }^{282}$ Ibid, p 238 'no sellers of fish shall throw their water into the king's highway, or into the lanes, but shall cause the same to be carried unto the Thames, under a penalty of two shillings'.

${ }^{283} \mathrm{Ibid}, \mathrm{p} 239$ 'all the lanes leading towards the Thames, from the king's highways, from Castle Baynard unto the Tower of London, shall be kept clear, that so persons on horseback may without hindrance ride and go unto the Thames; and if it be not so, the sheriffs shall cause the same to be done at the cost of those who have caused the impediment; and nevertheless, let those who thus impede be heavily amerced.'

${ }^{284}$ Ibid, p 239 'no courtesan [or] common brothel-keeper shall be residing within the walls of the city, under pain of punishment.'

${ }^{285} \mathrm{Ibid}, \mathrm{p} 240$ 'It is also forbidden, that any person shall be so daring as to be found going or wandering about the streets of the city after curfew rung out...with sword or buckler, or with any other arm for doing mischief whereof evil suspicion may arise, or in any other manner; 
(ii) shutting the doors of taverns and brewers at curfew; 286

(ji) persons arrested for some grievous cause not to be released without the assent of the mayor;

(kk) boatmen; 287

(11) carrying bows;

(mm) lime;

$(\mathrm{nn})$ tiles;

(oo) balances and measures;

(pp) paviours (i.e. those who made pavements);

(qq) butchers;

(rr) pelterers.

It would seem likely - given the considerable overlap with the Ordinance of 1277- that this Ordinance was designed to supercede the former. ${ }^{288}$ However, like the former - when it referred to various acts being prohibited so as not to be 'to the disturbance or annoyance of folks' [citizens]' - this was the rationale for the offence. There is no suggestion there was a generic crime of public nuisance. If so, it would not have been necessary to list out these minor crimes.

\section{(c) City Ordinance - c. 1285}

The Liber Albus (1419) also contains certain Articles, although the heading for them is in the Liber Custumarum, which states:

These are the Ordinances ${ }^{289}$ which king Edward [I] made when he took into his hand the franchise of the City. And some of them are in use at the times when it [the City] enjoys its franchise [i.e. continue to apply]. ${ }^{290}$

Since Edward re-took the City into his hand in the period 1285-98, the Ordinance dates from this period. ${ }^{291}$ Probably, close to the start of it. The Ordinance provided that a Warden be appointed for the City in place of the mayor. It also indicated that it over-rode any franchise (liberty) or 'ancient usage' the City might have. ${ }^{292}$ Among other things, this Ordinance contained provisions regulating:

(a) misdoers who lay concealed; ${ }^{293}$

(b) prostitutes (common women) were to be banned from the City;

(c) watch and ward; ${ }^{294}$

unless it be some great lord or other substantial person of good reputation, or a person of their household, who from them shall have warranty...'.

${ }^{286}$ Ibid, p 240-1 'whereas such persons going about by night do commonly have their resort and hold their common meetings in taverns more than elsewhere, and do there seek shelter, and lie in wait and watch their time to do ill, - it is forbidden that any person shall keep a tavern for wine or for ale open after the hour of curfew aforesaid; but they shall keep their taverns closed after such hour. Nor shall they have any persons therein, sleeping or sitting up; nor shall any one receive persons into his house from out of a common tavern, by night or by day, except those for whom he shall be willing to be answerable unto the peace of the king....And if any taverner shall receive any bad character, knowing that he has been a transgressor, he shall have the imprisonment that is provided for all receivers of felons.'

${ }^{287}$ Ibid, p 242, in particular 'nor may they carry any man or women, either denizens [i.e. residents] or strangers, unto the Stews [brothels in Southwark], except in the day-time, under pain of imprisonment.'

${ }^{288}$ These is also some disorder and repetition in this Ordinance which suggests that, in 1419, when they compiled the Liber Albus, they did not have the original or that it was mutilated.

${ }^{289}$ They were also called 'Articles', see p 248.

${ }^{290}$ Ibid, p 244.

${ }^{291}$ See also Letterbook A, n 66, introduction (by the editor RR Sharpe), p xi ' The year 1285 was a memorable one in the City's annals as marking what was little less than a civic revolution. The City lost its franchise, and for thirteen years was 'in the king's hand', being governed by a Warden of his selection and appointment, instead of by a Mayor appointed by the citizens. Many fresh regulations were made...upon this change of government...'

${ }^{292}$ Ibid, p 245 'the king doth will, that all understand that no franchise or ancient usage shall hold good, by reason whereof this present Ordinance may not be observed.' (italics supplied)

${ }^{293}$ Ibid, p 245-6 'whereas some persons do resort unto the City, in some cases from beyond the sea; and others of this land do there seek shelter and refuge, by reason of banishment from their own country, and of having for great offences or other misdeeds had to fly from their country; and of such, some become brokers, hostelers, and herbergeours [i.e. lodging house keepers] within the City, for denizens and for strangers, as freely as though they were good and lawful men, and of the freedom of the City. And some of such know nothing but how to go up and down about the streets, more by night than by day, and are well attired as to clothing and array, and feed upon delicate meats and costly; and are employed upon no trade or merchandise, nor have lands nor tenements by which to live, or any friends who may find them, and are continually removing from one house to another: and through such persons do arise many of the perils [that occur] in the City, and many of the evils [therein]. And some [again] are found openly offending, as by robberies and other evil deeds. ' It then provided that no foreigner could be a herbergeour or hosteler in the City unless he was a freeman and confirmed as a good and lawful man.

${ }^{294}$ Their duty was, p 247 'to arrest and attach those who act and go about by night, in breach of the peace...' 
(d) place for weighing goods;

(e) servants buying merchandise and goods;

(f) feoffees not trading to pay tallage;

(g) merchants coming to the City not to be molested;

(h) merchant strangers (i.e. foreign merchants);

(i) penthouses and gutters; ${ }^{295}$

(j) weaving woollen cloth $e t c$; 296

(k) labourers;

(l) fishmongers and poulterers;

(m) no one to receive tenants of others;

(n) all persons to be obedient to City officers.

This Ordinance of 1285 referred to prior usages ('all usages heretofore in the City established.'). Thus, likely, it was designed to supercede, inter alia, the Ordinance of 1281 - to the extent it so provided - but, otherwise to supplement it. ${ }^{297}$ This Ordinance - like those previously discussed - also appears to be an attempt to consolidate prior common law material since it states:

the king doth will, that all understand that no franchise or ancient usage shall hold good, by reason whereof this present Ordinance may not be observed. ${ }^{298}$

\section{In conclusion, what later legal writers such as Hawkins (see 17) thought were common law public nuisances were actually statutory.}

\section{LONDON - EDWARD II (1307-27), EDWARD III (1327-77) \& RICHARD II (1377-99)}

The Ordinances of Edward I - likely, the Ordinance of 1285 being the paramount Ordinance - laid down the 'City law' - what would be termed 'byelaws' today. They comprised legislation since they were Ordinances made by the king (or the king and his Council). However, the terms of these Ordinances needed to be simplified in order for the local courts of the 24 London wards (the wardmotes) to comprehend and act upon them (not least since many of the jurors would have been illiterate). Thus:

- $\quad$ Articles. In these courts, once the requisite number of citizens were appointed jurors - and with the relevant head of the ward, the Alderman, acting as judge - there was read out to them the 'Articles of the Wardmote'. That is, the matters over which their court had jurisdiction in their ward;

- $\quad$ Inquest \& Presentment. In respect of these matters, the jurors made injury (inquest) as to whether a crime had been committed. They then 'presented' (made presentment) of their verdict to the judge (the Alderman). In the case of more minor crimes, their verdict was the decision of the court. In the case of more serious crimes, they indicated that they thought a crime had been committed - leaving judgment to a higher court.

\section{(a) Edward II}

The Liber Albus contains sample Articles of the Wardmote and the Inquests, said to be of the time of Edward II (1307-27). These provide that the jurors were to be asked whether - in their ward, since the last wardmote:

(a) the king's peace had been broken - or there had been any affray (and by whom);

(b) any resident or person therein was not a lawful person or of good fame or under frankpledge;

(c) any woman resident was of lewd life, a common scold, a common bawd or a prostitute;

(d) there was any oven, furnace or defective reredos where there may arise misadventure by fire. Or, if any wood or fuel was used contrary to the Ordinance; ${ }^{299}$

(e) any taverners, brewsters (brewers), hostlers or chandlers ${ }^{300}$ had sold without sealed measures or against the Assize. Or received gamsters or other riotous persons after the hour forbidden by the

\footnotetext{
${ }^{295}$ Ibid, p 250 'the king doth will, that all usages heretofore in the City established, for the amendment and profit of the City, as to the streets, keeping clean of lanes without accumulation of dung and filth, and free from annoyance by chips and stones, penthouses [projections], gutters, jettees of houses, stands for carts shod with iron for the use of the City, corn-porters, carts with wood for sale, [shall be observed], that so no one enter the City except at the certain place thereunto assigned.'

${ }^{296} \mathrm{Ibid}, \mathrm{p} 250$. A note indicates that the title is incorrect since it contains an aggregate of former ordinances, see pp $250-1$.

${ }^{297}$ This is also other material in the Liber Albus which seems to have dated from the time of Edward I [1272-1307] in respect of: (a) corn; (b) fraudulent millers; (c) brewers; (d) bakers; (d) ale, see Liber Albus, n 64, pp 306-13, and for fishmongers, Ibid, pp 327-32.

${ }^{298}$ See n 292.

${ }^{299}$ There was a deep fear of fire escaping since London had been burnt down many times. This was only, effectively, dealt with when houses were made of stone and roofs of tile - something not to occur, generally, until the reign of James I (1603-25). A fn in the Liber Albus, $\mathrm{n}$ 64, $\mathrm{p}$ 287 indicated that a 'reredos' was 'An open fire grate, such as was commonly used in the middle of ancient halls.'
} 
Ordinance [i.e. after the curfew]. Or, there were any persons outlawed;

(f) there was any huckster [i.e. a pedlar or hawker who sold house to house] in the ward; ${ }^{301}$

(g) any house was covered with roofing other than tiles, lead, [or] stone, and none with reeds or straw;

(h) there was anyone whose practice was to place rubbish in the streets or lanes. Or, offensively before the doors of others;

(i) any bargain or usury had been made;

(j) any purprestures were made in the streets or lanes or on the walls or fosses [ditches] or on the Thames or other common soil;

(k) any baker of tourte bread [i.e. coarse brown bread] had baked white bread, or the converse;

(1) any persons had been in the habit of wandering after forbidden hours [i.e. after the curfew] and in a manner forbidden by the Common Council [i.e. nightwalkers];

(m) any City officer had practised extortion or affray under colour of his office;

(n) any person was a maintainer or champertour of litigation;

(o) anyone had paid wages to labourers more than ordained;

(p) any [tavern] alestake was longer, or extended further, than ordained. ${ }^{302}$

Those of the above which might be described as nuisances (I have placed them in italics) were statutory (governed by Ordinances). ${ }^{303}$ Also, in June 1319, by letters patent, Edward II (1307-27) confirmed certain new Articles (Ordinances) to be observed in the City and suburbs which had been submitted by the mayor, aldermen and citizens to him. ${ }^{304}$

\section{(b) Edward III}

In the reign of Edward III (1327-77) there appear to have been further Ordinances regulating the City, viz.

- In 1363, Edward III (1327-77) promulgated Articles (Ordinances) to govern the City. ${ }^{305}$ These included provisions on:
(a) nightwalkers; ${ }^{306}$
(b) no one to go about armed;
(c) hostelers;
(d) power to arrest felons and misdoers;
(e) no one to draw a sword or knife;
(f) champertors;
(g) answering [i.e. being responsible] for men in service;
(h) watches for keeping the peace;
(i) pleas before the mayor.

- Of uncertain date in the time of Edward III (1237-77) there were Articles promulgated on:
(a) hostelers; ${ }^{307}$
(b) the Thames; $;^{308}$

\footnotetext{
${ }^{300}$ This was, probably, a reference to any retailer or dealer rather than to a person who dealt in the supply of candles as such.

${ }^{301}$ OED, $\mathrm{n} 4$ (huckster) 'A retailer of small goods, in a petty shop or booth, or at a stall; a pedlar, a hawker.'

${ }^{302}$ Liber Albus, n 64, pp 287-92. The alestake was a pole projecting from a house supporting a bunch of leaves, to indicate it was a tavern. See also Ibid, n 64, pp 292 and 389 (fine of $40 \mathrm{~d}$ if more than 7 feet).

${ }^{303}$ For example, (b) referred to frankpledge and (o) related to the Statute of Labourers 1349.

${ }^{304}$ Letterbook D, n 66, p vi.There was also issued a writ by the king bidding the mayor, aldermen and citizens to see these Articles were duly observed. See also Letterbook E, n 66, pp 104-5. For the articles see Liber Custumarum, n 65, vol 1, pp 268-73.

${ }^{305}$ Liber Albus, n 64, pp 334-7. Ibid, p 334 'Writ as to the proclamation of certain Articles. The king to the mayor and sheriffs of London, greeting. We send unto you, enclosed in these presents, certain Articles concerning our peace in the said City, by us and the Council ordained...commanding you, and strictly enjoining that...you do cause all the Articles aforesaid publicly to be proclaimed in the City...and strictly to be observed.'

${ }^{306}$ Ibid ' that no one be so daring as to go wandering about within the said City, or in the suburbs, after the hour of curfew...unless he be a man known to be of good repute, or his servant, for some good cause, and that with a light...and if any one shall be found wandering about, contrary to this Ordinance, he is to be forthwith taken and sent unto the prison of Newgate, there to remain until he shall have paid a fine unto the City for such contempt, and have found good surety for his good behaviour.' For cases on the same see Letterbook D, n 66, pp 262 7 (1310-1).

${ }^{307}$ Liber Albus, n 64, p 409 'whereas heretofore it has been ordained, for the preservation of the peace, that no man should harbour another beyond a day and a night [in Anglo-Saxon times, it was 3 days, see n 102] if he should not wish to make answer for him, in case he should offend; as to which no penalty was ordained, and no punishment given; and therefore the said Ordinance was by no one at all regarded: it is ordained, that no one should harbour or maintain any man or woman who is of ill repute, or notoriously suspected of bad conduct, or who shall have so behaved, under pain of paying forty shillings unto the community, if he be thereof attainted.'

${ }^{308}$ Ibid 'whereas the watercourse of the Thames, which is wholly pertaining unto the City, is greatly impeded by the purpresture of quays
} and other encroachments made in the said water, to the great damage and peril of all the City: it is ordained by the Mayor and Aldermen, 
(c) hoardings; ${ }^{309}$

(d) purprestures. ${ }^{310}$

It should also be noted that a Charter of 1341 granted by Edward III (1327-77) to the City gave the Common Council of the City a wide measure of self-regulation, such as to obviate the need to obtain the formal assent of the sovereign in more minor matters. It provided that:

where any customs theretofore used and obtained proved hard or defective, or any matters newly arising within the City needed amendment and no remedy had been previously provided; to apply and ordain a convenient remedy as often as it should seem expedient; so that the same were agreeable to good faith, and reason, for the common advantage of the citizens, and other liege subjects sojourning with them, and useful to king and people. ${ }^{311}$

\section{(c) $\underline{\text { Common Council Regulations }}$}

It also seems that, in 1387, the mayor and aldermen of the City - with the assent of the Common Council passed an Ordinance on:

(a) dogs not to wander about the City; ${ }^{312}$

(b) ale stakes;

(c) driving carts. ${ }^{313}$

And, at some time in the reign of Richard II (1377-99) - it may be c. 1382 - the Mayor and Alderman of the City - with the assent of the Common Council - passed an Ordinance on:

(a) punishment of courtesans (prostitutes), bawds (procurers) and scolds ${ }^{314}$ - including the thewe for scolds; ${ }^{315}$

(b) corn. $^{316}$

\section{(d) Liber Albus -1419}

with the assent of the Commons, that from henceforth no purpresture shall be made by the erection of quays, or in any other manner, upon the water of Thames, without view of the Mayor, Aldermen, and Commons; and by them it shall be adjudged, whether no peril or damage will from such purpresture unto the City ensue.'

${ }^{309}$ Ibid, pp 409-10 'that no hoards, or palings, or other enclosure, shall be made before any tenement in the high streets or lanes in the City, or in the suburbs thereof, before that the same shall be viewed by the Mayor and Aldermen. And if they shall see that such works are prejudicial, the same shall be in no manner allowed. And in the same manner let it be done as to steps which persons shall wish to make to cellars, the entrances to which extend out into the high streets and lanes; and let those which are made be forthwith viewed and rectified.'

${ }^{310}$ Ibid, p 410 'that all master-carpenters and masons of the City shall be sworn that they will make no purprestures upon streets or lanes within the City, or the suburbs, not yet to the prejudice of the neighbours where they shall make the buildings, contrary to the Statutes of the City from ancient time ordained.' The words in italics likely include reference to the building regulations of 1189 , see $\mathbf{6 ( a )}$.

${ }^{311}$ See McBain, $\mathrm{n}$ 66, p 50. The Recorder of the City can also declare whether a custom be one or not. See charter of 1462. Ibid, p 45. See also Lex Londinensis or the City Law (1680), p 8.

${ }^{312}$ Liber Albus, n 64, pp 388-9 'to avoid the noise, damage, and strife, that used to arise therefrom, it is forbidden that any person shall keep a dog accustomed to go at large out of his own enclosure without guard thereof, by day or night, within the franchise of the City, genteel [possibly, this means pet] dogs excepted; under pain of paying forty pence, to the use of the Chamber.'

${ }^{313}$ Ibid, p 389 'no carter within the liberties shall drive his cart more quickly when it is unloaded, than when it is loaded; for the avoiding of divers perils and grievances, under pain of forty pence unto the Chamber, and of having his body committed to prison at the will of the Mayor.'

${ }^{314}$ Ibid, p 394 'Whereas in divers wardmotes holden before the aldermen in their wards, there are indicted by the good folks of the ward certain men as common whoremongers [i.e. visitors to brothels], common adulterers, and common bawds [pimps]; as also, certain women, as common courtesans [whores], common adulteresses, common bawds, and scolds; for the purpose of removing them out of the City, or for making them cease so to offend, to the pleasing of God, the salvation of their souls, and the cleanness and honesty of the said City; of whom no correction has heretofore been made, because no Ordinance thereupon has been made, but rather, they have been suffered and allowed....It is ordained...' (italics supplied).

${ }^{315}$ Ibid, 'if any man or woman shall be attainted [convicted] of being a brawler or scold, let such person be taken unto the thew, with a distaff dressed with flax (called 'dystaf with towen') in his or her hand, with minstrels, and be set thereon [a thewe] for a certain time, at the discretion of the mayor and aldermen.' An editor's note in the Liber Albus, n 64, p 395 describes the thewe as 'a kind of pillory, used mostly for the punishment of women.' Given the reference to no prior punishment provided by an Ordinance, see n 314, this may have been the first time that the punishment of the thewe was prescribed for a common scold (male or female). However, one is dubious whether the thewe was a reference to the pillory, as opposed to the ducking stool. The pillory could be highly dangerous and men were killed when placed in it (since, not just food was thrown at them). Further, it could result in indecency in a woman (aiming at the breasts etc). Therefore, a ducking stool would seem more appropriate. OED n 4 (thewe) 'Name of an apparatus or instrument of punishment ordained, instead of the pillory, for women; often identified with the cucking-stool.'

${ }^{316}$ Liber Albus, n 64, pp 394-7. 
It seems clear that, by 1419, the various Ordinances governing the City were is dis-array or lost or uncertain. Therefore, the Liber Albus (White Book) of the City was complied by John Carpenter, the Common (Town) Clerk, in the mayoralty of Richard (Dick) Whittington. ${ }^{317}$ The compilation was in the form of a 'Reportory' which comprised an assembly of regulations in latin and in Anglo-Norman (law french). Referring to the fallibility of human memory, ${ }^{318}$ Carpenter stated that his compilation contained:

not only those laudable observances which, though not written, have been usually followed and approved in the said City, to the end that they may not be lost in oblivion hereafter, but also those noteworthy memoranda which have been committed to writing, but lie scattered in disorder in manner before mentioned; that so, by their being ascertained, the superior authorities of the said City, as well as those of subordinate rank, may know henceforth with greater accuracy what in rare and unusual emergencies should be done etc. ${ }^{319}$

In his Liber Albus, Carpenter included the material referred to in (a)-(c) above. This suggests it was a fairly accurate compilation of what comprised the regulations of the City in 1419 and how defaulters were punished. This material was all statutory.

\section{(e) Any Common Law City Nuisances?}

Besides the Liber Albus, the Letterbooks and Memoranda of the City refer to other examples of nuisances, some of which do not appear - at first glance - to have derived from any Ordinance. These may be identified by the fact they were punished by the pillory or tumbrel (or thewe, in the case of common scolds) - the punishment allocated for the statutory nuisances. In the Liber Albus, Carpenter (usefully) listed these by reference to material in the Letterbooks. ${ }^{320}$ With regard to the later development of the common law crime of public nuisance, the following may be noted:

- Unwholesome Food. Frequently, butchers and others were punished for selling (or exposing for sale) unwholesome food. ${ }^{321}$ While the source of this in very early times may have been the common law (part of the law of cheat), ${ }^{322}$ the Assize of the Pillory (c.1266) imposed a punishment for selling putrid food on butchers as well as on others. ${ }^{323}$ Thus, its basis by 1266 seems to have been statutory - although later legal writers (perhaps, forgetting this Assize, although it was not repealed until 1863) seem to have treated the offence as one of public nuisance. ${ }^{324}$

\section{In conclusion, this was a statutory crime as well as a common law crime of cheat - no public nuisance also being} required to be proved.

- $\quad$ Selling Underweight Goods etc. London traders were frequently punished for selling goods not of correct weight or measure. For example, bakers selling bread below weight. However, the correct weight or measure was, invariably, governed by some Assize - such as the Assize of Weights or of Measures or of Bread or Ale or of the Pillory. Thus, these minor crimes had a statutory basis.

\footnotetext{
${ }^{317}$ This text had become so dog eared that a duplicate was made in 1582 under Robert Smith, Comptroller of the Chamber. It was actually the one called the 'White Book' and Carpenter's version was termed by officials at the Guildhall as the 'Black Book'. Liber Albus, $\mathrm{n}$ 64, $\mathrm{p}$ viii. ${ }^{318}$ Liber Albus, n 64, p 3 'Forasmuch as the fallibility of human memory and the shortness of life do not allow us to gain an accurate knowledge of everything that deserves remembrance, even though the same may have been committed to writing, - more especially, if it has been committed without order or arrangement, - and still more so, when no such written account exists; seeing too that when, as not unfrequently happens, all the aged, most experienced, and more discreet rulers of the royal City of London have been carried off at the same instant, as it were, by pestilence, younger persons who have succeeded them in the government of the City, have on various occasions been often at a loss from the very want of such written information; the result of which has repeatedly been disputes and perplexity among them as to the decisions which they should give: it has been long deemed necessary, as well by superior authorities of the said city as by those of subordinate rank, that a volume - from the fact of its containing the regulations of the City, it might be designated a 'Repertory' - should be compiled from the more noteworthy memoranda that lie scattered without order or classification throughout the books [and] rolls, as well as the Charters of the said city.'

${ }^{319}$ Ibid, p 4.

${ }^{320}$ Ibid, pp 517-26 'Judgments of Pillory for Lies, Slanders, Falsehoods, and Deceits; as also, other Judgments, Imprisonments, Forfeitures, Fines, and Burnings of divers things.'

${ }^{321}$ See the frequent references in the Liber Albus, n 64, pp 517-26.

${ }^{322}$ GS McBain, Modernising the Common Law Offence of Cheating the Public Revenue (2015) Journal of Politics and Law, vol 8, no 1, pp 40-82. Cheat was abolished by the Theft Act 1968, s 32(1).

323 'if any butcher do sell contagious flesh, or that dies of the murrein [i.e. the plague]. Also, they shall inquire of cooks that seethe [boil] the flesh or fish with bread or water, or any otherwise, that is not wholesome for man's body or after they have kept it so long that it loses its natural wholesomeness, and then seethe it again, and sell it [or if any do buy flesh of Jews, and then sell it to Christians].' See also Ritson, $\mathrm{n}$ 120, p 32. Also, Mirror (c.1290), n 27, p 40 'Of butchers and cooks who sell measly flesh for sound, and half raw for well cooked. Of those who sell corrupt wine for sound, and beer hard or redened or made of oats or of flea-bane for wholesome and sound.' See also Brooke, $\mathrm{n} 33$, Leete 1. Also YB 9 Hen 6 pl 37 fo 53b (1430), Seipp no 1430.083 (Common Pleas. Deceit on the Case. Selling Spoiled Wine).

${ }^{324}$ See also $25(\mathbf{a})$.
} 
In conclusion, these were statutory crimes - no public nuisance also being required to be proved.

- Nightwalking. It was said that William I (1066-87) imposed a night curfew, to prevent violence and uprising. ${ }^{325}$ This may have been more intermittent in succeeding reigns. However, the City Ordinance of c. 1281 (see 11(b)) punished those wandering about in the City after the curfew. This was, usually, 9 pm (or dusk, if earlier) until 6 am - during which time the City gates (there were seven of them) were closed. ${ }^{326}$ Closure of the gates was provided in the Statute of Winchester (Statutum Wynton) 1285. ${ }^{327}$ The relevant chapter (section) of the Statute of Winchester was repealed in 1827 - although it is probable that night curfews in London ended by the 16th century. ${ }^{328}$

In conclusion, this crime was a statutory nuisance, not a common law - no public nuisance also being required to be proved. In any case, nightwalking was abolished by the Criminal Law Act 1967.

- $\quad$ Eavesdropping (Talebearing). Often, this offence was treated as a common law one. However, it probably related to that of spreading false news or tales, a crime punished by the Statute of Westminster the First 1275, chapter (section) $34 .{ }^{329}$ This section was repealed in 1887 . However, eavesdropping may have continued as a form of cheat - a crime abolished in 1968 (apart from cheating the revenue).

In conclusion, this crime was a statutory nuisance or part of the crime of cheat - no public nuisance also being required to be proved. In any case, nightwalking was abolished by the Criminal Law Act 1967.

- Common Scold. The articles of the wardmote of the time of Edward II (1307-27) refer to a common scold (see 12(a)) and the Liber Albus ${ }^{330}$ and the Letterbooks refer to persons being punished for such an offence - albeit such references are rare. Was this a statutory or common law crime? The source of this offence is obscure. ${ }^{331}$ The Liber Albus refers to persons being punished by the pillory for lying or for opprobrious words ${ }^{332}$ - which may suggest

\footnotetext{
${ }^{325}$ De Laune, n 207, pp 276-7 'William the Conqueror commanded that in every town and village a bell (call'd curfew bell) should be nightly rung at eight of the clock, and that all people should then put out their fire and candle, and take their rest; which order was observed in his reign, and the reign of William Rufus [1087-1100]; but Henry the First [1100-35] revoked the Order. But Henry the Third [1216-72] anno 1253 commanded watches in cities and boroughs to be kept, in order to the preservation of peace and quietness among his subjects etc.'

${ }^{326}$ See McBain, n 70, p 190. See also Letterbook C, n 65, p 85 (Ordinance of 17 May 1282] 'At each parish church curfew shall be tolled the same hour as at St Martin [St Martin Le Grand], beginning and ending at the same time, and then all gates as well as taverns, whether of wine or ale, shall be closed, and no one shall walk the streets or places. Six competent persons shall keep watch by night by view of two of each Ward, and two sarjeants keep guard over the gates by day, lying by night in or near the gates.'

${ }^{327} 13 \mathrm{Edw} 1$, ch 4 (rep $7 \& 8$ Geo 4 c 27(1827)) 'in great towns, being walled, the gates shall be closed from the sun-setting until the sunrising; and that no man do lodge in suburbs, nor [in any place out of the town; from nine of the clock until day] without his host will answer for him.' See also McBain, n 70, p 190 and Ritson, n 120, p 28.

${ }^{328}$ Once the gates were taken down (c. 1660), nightwalking was not linked to the curfew as such and the apprehension of nightwalkers became part of the general duty of the night constable to arrest those he suspected of committing a crime. De Laune, n 207, p 277, stated (c. 1690) 'There are in the respective streets convenient stations for the watchmen, who are citizens, and obliged to perform that duty in their turns with their officers and are to examine all persons that walk in unseasonable hours and to apprehend suspicious persons or such as are riotous or otherwise misbehave themselves, and secure them. At set and convenient times, they appoint a party to go their rounds, and to apprehend such as they find tipling in victualling houses at unseasonable hours, in houses of ill name, or nightwalkers, or any other persons whatsoever that are uncivil, or cannot give a good account of themselves, and the reason of their being abroad...'. See also an Act of Common Council made in the mayoralty of Sir John Robinson entitled 'An Act for the better ordering of the Night Watches within the City of London and Liberties' contained in Lex Londinensis, n 186, p 173-85 (nightwalking in the wards from 9 pm-7 am. Ibid, p 177). See also McBain, n 70, pp 190-2.
}

${ }^{329}$ Statute of Westminster I (1275) c.34 (spreading false rumours)(rep 1887). See Coke, n 43, vol 2, pp 225-8 and McBain, n 70, pp 192-3. This crime likely had a Biblical source (Book of Exodus, ch 23, v 1, Book of Leviticus, ch 19, v 16, Proverbs, ch 26, v 20). See also R Crompton, Star Chamber Cases (a Boston, Soule \& Bugbee 1881 reprint of ed of 1630 or 1641 rep by the Law Book Exchange, 2008 ), p 15. ${ }^{330}$ Liber Albus, n 64, p 394. See also n 314. Powell (in 1668), n 134, p 91 'The evildropper who is a species of a barretor.'

${ }^{331} \mathrm{G}$ Jacob, A New Law Dictionary (7th ed, 1757)(scolds) 'In a legal sense are troublesome and angry women, who by their brawling and wrangling amongst their neighbours, break the public peace, and increase discord. Stat $51 \mathrm{H} 3$ [1266, a reference to the Assize of the Pillory c 1266]. They are indictable in the sheriff's turn, and punished by the cucking stool etc.' Jacob cited Kitchin. See e.g. J Kitchin, Jurisdictions or the Lawful Authority of Courts Leet etc (1653), p 20 (charge in court leet) 'if there be any common barretors in the lordship, as scolds, brawlers, to the noyance and disturbance of their neighbours, present their names.' (italics supplied)

${ }^{332}$ Liber Albus, n 64, pp 517 (man committed to prison for divers opprobrious things said to a certain serjeant in the presence of the mayor c 18); p 518 (prison for a year and a day and pillory each quarter for 3 hours with a whetstone tied round his neck for lies which were disproved - G 138); p 519 (pillory for lies with a whetstone round his neck - G 272). Riley noted, n 64, p 518 'The origin of this custom [of the whetstone round the neck] seems not to be known. The whetstone was jocularly said to be the reward of the person who told the greatest lie; and 'lying for the whetstone' is a phrase often met with in our old writers.' Also, p 521 (judgment on Roger Thorolde for speaking ill of the mayor in his absence - $\mathrm{H} 42$ ); 521 (pillory for lies uttered against the mayor and aldermen - H 88; p 522 (pillory for lies uttered against William Walworth - H 114; p 522 (H 138, pillory for lies); p 522, H 143 (lie told of the mayor); p 523 (bedel removed from office for lies H 229); p 256 (lies uttered against John Tremayn, the recorder); p 524 (pillory for lies against the mayor - H 162-5), H 258 (for falsehood and deception, thewe for lies); p 525 (lies uttered against Thomas Fauconere - I 106); p 526 (judgment on Thomas de Albertis for falsehood and deception - I 162); p 526 (imprisonment of Robert Cristendom for scandalous words - I 187); p 526 (judgment on Thomas Russelle for opprobrious words, lies and scandals uttered against Thomas Fauconer, alderman). The references to the letters are to the Letterbooks, $\mathrm{n} 66$. 
this was a 'City specific' crime. However, the common law crime of barratry is very similar to that of being a common scold. ${ }^{333}$ Thus, it seems likely that the latter was part of barratry (it also seems the punishment of the thewe for this crime, as opposed to the pillory, only arose in 1382) ${ }^{334}$ It was also often said (by legal text writers) that a common scold could only be a woman (communis rixatrix) and not a man. This would appear incorrect. ${ }^{335}$ Finally, common scolds tended to be closely associated with prostitutes in early times ${ }^{336}$ - although, later, those punished were persons who breached the peace by habitually quarrelling with others. ${ }^{337}$ Thus, the crime may have changed over time.

In conclusion, this crime was part of the crime of battary - no public nuisance also being required to be proved. In any case, barratry was abolished by the Criminal Law Act 1967.

- Cheat. This crime not only covered the sale of goods not according to the due weight or measure; it also covered mis-representing the quality, or nature, of goods. They were described as 'false' or 'unsound'. By Victorian times, these epithets had changed. Such goods tended to be called 'defective', 'deficient ' or 'adulterated.' Cheat also covered people: (a) pretending to be important persons or officials; (b) deceiving others by lies (falsehoods); (c) slandering others - especially important persons or officials; and (d) pretending to be a beggar. Also, the counterfeiting of goods. ${ }^{338}$ Thus, many asserted common law nuisances were covered by the separate common law crime of 'cheat' - the word 'cheat' being 16th Romany cant for the wide medieval crimes punished as 'deceites', 'malx faits' (evil deeds) and 'decepciones' (deceptions). ${ }^{339}$ This crime, basically, covered any gaps in the legislation.

In conclusion, the crime of cheat was abolished by the Criminal Law Act 1967 (apart from cheating the revenue).

\section{(f) Conclusion}

While there are many examples of public nuisance in respect of the City and while these may have been common law public nuisances - by 1285 - most were statutory. As to the remainder - such as:

- $\quad$ selling unwholesome food (Assize of the Pillory c. 1266);

- $\quad$ selling underweight goods or by incorrect measure (Assize of Measures c. 1266 etc);

- $\quad$ nightwalking (Statute of Winchester 1285 and City Ordinances);

- $\quad$ eavesdropping (Statute of Westminster 1275 (false news);

- $\quad$ managing a brothel (Ordinance of 1161, restricting them to Southwark);

- $\quad$ expelling prostitutes from the City (City Ordinances).

these were also statutory (the source is indicated in brackets). As for the common scold, this crime would seem to be a variant of the common law crime of barratry - the variant being that it may have been restricted to women (though this is dubious since it seems to have applied to men as well in early times). Alternatively, it may be that it was punished differently, the punishment being the thewe (though this punishment seems only to

\footnotetext{
333. Walker, n 5, (barratry) 'The common law offence in England of exciting and maintaining suits and quarrels in the courts or in the country, as by disturbance of the peace or spreading false reports and rumours which provoke discord between neighbours. This crime was abolished, as obsolete, in 1967.' Coke, n 43, vol 1, s 702 'A barrettor is a common mover and exciter, or maintainer of suits, quarrels, or parts, either in courts, or elsewhere in the country....'barretor' is derived of this word (barret) which signifies not only a wrangling suit, but also such brawls and quarrels in the country as are aforesaid.' Powell (in 1668), n 134, p 91 treated a scold as a type of barretor 'If there be any common barretors...they are of both sexes, scolds, brawlers, common malefactors, disturbers and disquieters of their neighbourhoods.' So did G Jacob, Compleat Court Keeper (1st ed, 1715), p 33 'common barettors, as scolds, brawlers and raisers of quarrels.'

${ }^{334}$ See n 315.

${ }^{335}$ Cf. RM Karras, Common Women. Prostitution and Sexuality in Medieval England (1996), pp 139 'Scolding and gossiping were not exclusive to women, though women occasioned by far the bulk of the charges'.

${ }^{336}$ Ibid, pp 100, 139-40. See also J Kermode \& G Walker, Women, Crime and the Courts in Early Modern England (UCL, 1994), ch 3 ( M Ingram). At p 51 'A scold was a turbulent, chiding, brawling person.' Ibid, p 69 'The modern word that best captures the sense of scolding is harassment, involving insult and sbuse that might well be repeated day after day and expressed with great verbal or even physical violence.' It is likely that the punishment of scolds was also linked to areas where puritanism was strong.

${ }^{337}$ See for a useful note on this English Legal Terms (pub Hephaestus Books).

${ }^{338}$ See Liber Albus, n 64, pp 517-26. See also Powell (in 1668), n 134, pp 121(he noted the court leet had jurisdiction over 'Deceits in Tradesmen. If any tradesmen or artificer whatsoever, does use any fraud, shift, slight, or deceit in the making of his and their ware and chaffer, and do not make the same as they ought whereby the people are deceived.'

${ }^{339}$ GS McBain, Modernising the Common Law Offence of Cheating the Public Revenue (2015) Journal of Politics and Law, vol 8, no 1, pp 40-82. For examples of selling unwholesome food being punished as cheat, Ibid, p 58.
} 
have been inflicted post 1382). As it is, this crime was rarely imposed. ${ }^{340}$ It would seem the last time punishment was inflicted was in 1809 , with Holt CJ treating it as a somewhat antiquarian curiosity in $1704 .{ }^{341}$

In conclusion, in the City - while there were many statutory nuisances - there appear to be very few common law ones (including in relation to the highways). There also does not seem (clearly) ${ }^{342}$ to have been a generic crime of public nuisance at common law.

\section{PERIOD 1290-1619}

In this period, there was little change to the position in 1290 save that the sheriff's tourn and courts leet ${ }^{343}$ were $^{3}$ given jurisdiction over additional statutory nuisances. Both legal writers (such as Adames in 1599) and the courts (such as Fairfax $\mathrm{J}$ in a case in 1482) emphasised that the rationale for punishing certain nuisances pursuant to the criminal law was that they were 'common'. However, there would seem to be no evidence of a generic crime of common nuisance as such in this period.

\section{(a) Sheriff's Tourn \& Court Leet}

The articles of the sheriff's tourn and those of courts leet continued to reflect those of the Statute of Wales 1284 (see 8(c)) in respect of common nuisances. This may be seen by comparing those of the Statute and the View (Statute) of Frankpledge which is often cited as legislation dating from 18 Edward 2 (i.e. 1325), although this date is uncertain. ${ }^{344}$

- $\quad$ Statute of Wales 1284. Of turning water courses. Of hindrance, restraint, and narrowing of the highway. Of walls, houses, gates, ditches, and marlpits raised and made near unto the public highway, to the nuisance of the same way, and to the danger of passengers; and of them that raise and make the same...(see 8(c));

- $\quad$ View of Frankpledge (c. 1325). Nos 7. Of purprestures made in lands, woods, and waters, to annoyance. 8. Of walls, houses, dikes and hedges, set up or beaten down to annoyance. 9. Of bounds withdrawn and taken away. 10. Of ways and paths [opened and stopped]. Of waters turned or stopped, or brought from their right course... ${ }^{345}$

The source of these two is likely Glanvill (see 5) in his description of purprestures and - prior to that - the crime of stretbreche, referred to in the Laws of Henry I (c. 1113)(see 4(b)). As it is, the View of Frankpledge (c. 1325) - with these articles on purprestures - continuing to be reflected in the articles of the court leet in medieval treatises (there was no standard version of the wording). ${ }^{346}$ However, since these differ little from the articles contained in Adames, The Order of Keeping a Court Leete and Court Baron (1593), ${ }^{347}$ the latter is considered.

\footnotetext{
${ }^{340}$ Cf. Curtey's Case (1611) Moore 847 (72 ER 945)(presentment in leet for being a common nuisance). See also Smith v Pannell (1618) Hob 246 (80 ER 392)(of railers and sowers of discord among neighbours). See also Ritson, n 120, p 37.

${ }^{341}$ Foxby (1704) 6 Mod 11 (87 ER 776). Also, pp 178, 213, 239, 311 (continuation of the case). Holt CJ appears to have accepted it still existed as a crime, however. Counsel in Sykes v DPP [1962] AC 528 at p 534 described this crime as obsolete.

${ }^{342}$ One says, clearly, since - if there had been - it would not have been necessary for the Ordinances. Citizens who, for example, let their pigs wander (or who threw rubbish in the streets) could have simply been prosecuted for common nuisance at common law.

${ }^{343}$ For texts on the court leet in this period, see: (a) J Adames, The Order of Keeping a Court Leete and Court Baron with the Charges appertayning to the Same (1593, imprinted at London by Thomas Orwin and William Kirchham, rep EEBO); (b) Maner of kepynge a Court Baron and a Lete (1st ed, 1542; last ed 1625); (c) Modus Observandi Curiam cum Leta (1527); (d) Modus tenendi Curiam Baronis cum Visu franem Plegii (c. 1515, rep Manorial Society, 1915); (e) Order of Keeping a Court Leet and Court Baron (1st ed, 1603; last ed 1650); (f) Boke that teacheth to keep a Court Baron and a Lete (1539). For early texts on courts leet, see generally, Sweet and Maxwell, A Legal Bibliography of the British Commonwealth of Nations, vol 1. English Law to 1800 (1955). J Baker, The Oxford History of the Laws of England, vol VI 1483-1558, pp 301-2 'In a court leet, the steward had the same judicial powers as the sheriff had in the hundred...In addition, a leet could punish...public nuisances....and could make bye-laws, which were enforceable by amercement, though such laws could not bind 'strangers'.' See also C Oestmann, Lordship and Community (1994), pp 117-9 (discussing the village of Hunstanton in Norfolk, infractions of the byelaws mainly concerned grazing rights and straying animals). For civil nuisance see Baker (ed), The Reports of Sir John Spelman, vol 2, SS, vol 94, pp 232-6 and SFC Milsom (ed), Novae Narrationes, SS, vol 80, pp xcvi-civ.

${ }^{344}$ It is also cited as 1324. Statutes of the Realm (1814), vol 1, pp 246-7. However, it is likely there were earlier versions.

${ }^{345}$ It also referred to '24. Of the Assize of Bread and Ale broken. 25. Of false measures, as of bushels, gallons, yards and ells. 26. Of false balances and weights. 27. Of such as have double measure, and buy by the great, and sell by the less. 28. Of such as continually haunt taverns, and no man knoweth whereon they do live. 29. Of such as sleep by day, and watch by night, and have nothing.' However, these relate to statutory matters. Thus, nos 24-6 (to the Assizes); 27 (to forestalling, see Assize of the Pillory c. 1266) and nos 28-9 (see City Ordinances, ns $286 \& 293$ )

${ }^{346}$ Hearnshaw, n 134, pp 57-62 (articles of frankpledge of c. 1307 and 1340). Also, Appendices IV and V (of the 14th century and c. 1501). See also; (a) 15th century articles of leet in C Kerrison, A Common-Place Book of the Fifteenth Century (1886), pp 160-6; (b) W Hudson (ed), Leet Jurisdiction in the City of Norwich during the 13th and 14th Centuries, SS, vol 5 (1892).

${ }^{347}$ See $n$ 343, text (a).
} 


\section{(b) $\underline{\text { Adames (1593) }}$}

This text is a useful indication of what public nuisances existed by 1599 . Noting the power of the lord of the manor to hold a leet. ${ }^{348}$ Adames set out the charge of the leet, which was addressed to the jury. It included purprestures (encumbrances). Thus the court leet jury was instructed to enquire:

if any purprestures be made upon the land, wood, or water, with blocks, stakes, ditch, hedge, or by, or with any other thing done to the nuisance of the people, that is to say, to the multitude, and not only to one: also, if any walls, houses, pales [palisades] or hedges be made or erected to the noyance of the people, this is to be presented. ${ }^{349}$

The Charge also referred - in respect of public nuisances - to the following :

(a) common highways, waters, ditches, paths; ${ }^{350}$

(b) encroachments; ${ }^{351}$

(c) lay-stalls (i.e. dung hills) and carrion (i.e animal carcases) placed in the public highway; ${ }^{352}$

(d) common barretors; 353

(e) eavesdroppers; ${ }^{354}$

(f) common hedge-breakers; ${ }^{355}$

(g) bawdy houses; 356

(h) vagabonds; ${ }^{357}$

(i) corrupting common waters; ${ }^{358}$

(j) false weights; ${ }^{359}$

(k) assize of bread and ale; ${ }^{360}$

(l) corrupt victuals. ${ }^{361}$

It is asserted that all of these minor crimes were statutory. Thus, the position had changed little from the Statute of Wales 1284. Also, while Adams referred to the 'nuisance of the people' and used the word 'common' in many instances, this was to distinguish private from public nuisance, since the leet had no jurisdiction over the former. There was no suggestion in his work that there was a generic crime of common nuisance existing at common law.

\footnotetext{
${ }^{348}$ Ibid, p 5 (the exhortation to be given to the jury at the court leet) 'the Queen's majesty and her noble progenitors have given and granted unto the lord of the manor, a strength and power to keep a leet or law day at two times in the year, which leet or law day all the headboroughs, tithingmen and desiners, and all other persons which be resident or dwelling within this leet, being of the age of twelve years or above, are bound by the law of this realm to appear: so that there they may hear the laws and statutes opened and declared, and thereby they may know and avoid the dangers of the same, and further to inquire of the breakers of the same: and to present them, that such offenders might be punished.'

${ }^{349}$ Ibid, p 12.

${ }^{350}$ Ibid, 'if any common highways, waters, ditches or paths be turned out of their courses....'

${ }^{351}$ Ibid, 'if any encroachment be made on the Queen's highways, or any of the lord's soil, common, or one neighbour upon another...'

${ }^{352} \mathrm{Ibid}$, 'if any laystalls [dunghills] be made in high ways to the noyance of the people, or if any carrion be cast in the high way...' OED, $\mathrm{n} 4$ (lay-stall) 'A place where refuse and dung is laid.'

${ }^{353}$ Ibid, 'if there be any common barretors in the lordship, as scolders and brawlers to the noyance and disturbance of their neighbours...'

${ }^{354}$ Ibid, 'if any eavesdroppers which stand under walls or windows, by night or day, to hear tales and to carry them to others, to make strife and debate between their neighbours...'

${ }^{355}$ Ibid, 'if there be any common breakers of hedges...' See also Statute of Westminster II 1285 (13 Edw 1, c 46)(overthrow of hedge or dyke). See also Powell (in 1668), n 134, p 12. It seems hedge breakers were prosecuted pursuant to the Statute of Westminster, e.g. J Tremaine, Placita Corone or Pleas of the Crown (1723), p 333.

${ }^{356}$ Ibid, 'if any keep and maintain any bawdry in their houses, it is cause of breaking the peace and is a vice that corrupts the Common weal, and for that cause it is here to be enquired of.'

${ }^{357}$ Ibid, 'if there be any vagabonds, and those which walk by night [i.e. nightwalkers], and sleep in the day, also if there be any that be common haunters of taverns or alehouses, having nothing to live upon...' See also City Ordinance 1281 , see ns $285,286 \& 293$. Tavern haunting became statutory, 1 Jac c 9 (1603, rep 1828)(An Act to restrain the inordinate haunting and tipling in Inns, Alehouses and other Victualling Houses).

${ }^{358}$ Ibid 'if any person have watered any hemp or flax in any river, running water, stream or brook, or in any common pond where beasts do use to drink, they shall forfeit for every time so doing, one pound...' This was statutory, 33 Hen VIII c. 17 (1541). Also Hearnshaw, n 134, p 125 .

${ }^{359}$ Ibid 'if any have and use any measures of bushells, gallons, yard or ell, or false balances, or pounds....'

${ }^{360}$ Ibid 'you shall enquire of the assize of bread and ale, that the same be kept, that is to say, that every one sell according unto the rate and price of grain, and that the same be made wholesome for man...'

${ }^{361}$ Ibid 'if butchers, fishmongers, or other victuallers sell any corrupt victual, not wholesome for man's body....'
} 


\section{(c) Further Legislation - Public Nuisances}

In this period 1290-1619, the court leet acquired jurisdiction over various additional statutory nuisances including:

(a) tracing hares (1523);

(b) destroying crows (1533);

(c) playing unlawful games (1541);

(d) watering hemp (1541);

(e) building cottages and harbouring inmates (1589);

(f) repressing drunkenness $(1607){ }^{362}$

More particularly, courts leet were given a greater jurisdiction over the improvement of public highways, pursuant to the following legislation:

- $\quad$ Highways Act $1555 .{ }^{363}$ The state of England's roads by Tudor times was very poor and this Act sought to remedy matters. This legislation required that every labourer in each parish was legally required to give 4 days (free) work a year on the highways. The days when he was required were to be announced in church. Further, every holder of plowland (tillage or pasture) in the parish - and every person keeping a draught or plough in the parish - was to provide a cart with two men for the purpose of mending the roads. Two surveyors were to be appointed at Easter each year to superintend this. Also, the Act provided that the:

steward of every leet or lawday shall...have full power and authority to enquire by the oaths of the suiters of all and every the offences that shall be committed within the leet or lawday against every point and article of this statute and to assess such reasonable fines and amerciaments for the same as shall be thought meet by the said steward. ${ }^{364}$

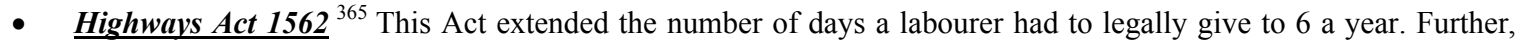
the Act provided that the hays, fences, dykes and hedges near the highway were to be maintained, and bushes and trees growing in the highways were to be cut down, 'whereby the said ways may be open and the people have more ready and easy passage in the same. ${ }^{366}$

How the courts in this period viewed the court leet may be seen from observations made by Fairfax $\mathrm{J}$ in a case in 1482. ${ }^{367} \mathrm{He}$ considered the jurisdiction of the sheriff's tourn and the court leet were the same ${ }^{368}$ and noted that the court leet - being a criminal court - only inquired of matters which were of a 'common' and not a 'private' nuisance. ${ }^{369}$ This reflected prior law.

\section{(d) $\underline{\text { Conclusion }}$}

It has been asserted that, in 1290 , there was no generic crime of public nuisance at common law. Such public nuisances as there were, were statutory or they comprised distinct crimes - such as that of being a common scold or managing a disorderly house. In the period 1290-1599, there appears to have been no change to this.

- In the case off the courts leet they acquired jurisdiction over additional public nuisances in the period 1290-1599. However, these were all statutory (see (c));

\footnotetext{
${ }^{362}$ Hearnshaw, n 134, pp 365-7 (listing the various pieces of legislation).

${ }^{363}$ 2-3 Philip and Mary c. 8 (rep 1766) (An Act for the Amending of Highways). It commenced 'For amending of highways being now both very noisome and tedious to travel in and dangerous to all passengers and carriages.'

${ }^{364}$ The fines went to mending the highways. See also, Hearnshaw, n 134, pp 126-7 and Powell (in 1668), n 134, pp 83-4.

${ }^{365} 5$ Eliz c. 13 (rep 1766)(continuation act). See also 18 Eliz c. 10 (1575, rep 1766), s 2 which provided that 'every person or persons that shall not repair ditch or scour any hayes, fences, ditches or hedge adjoining to any highway or common faring way. or shall not cut down or keep low all trees and bushes growing in or next adjoining to any the said ways' was fined $10 \mathrm{~s}$ for every default.

${ }^{366} \mathrm{Ibid}, 5$. A person who scoured ditches and threw the soil on the highway was fined. See also Powell (in 1668), n 134, p 85.

${ }^{367} 22 \mathrm{Edw} 4 \mathrm{pl} 2$ fo 22a-23b (1482), Seipp no 1482.119 (presentment of rape brought before a Court Leet). See also Brooke, n 33, Leete, no 26.

${ }^{368}$ Ibid. Seipp commentary "Fairfax JKB: ...the power (jurisdiction) of a sheriff in his tourn, and the power of a steward in his leet is one (un, the same) and each of them is the king's court (le court le roy), but the king has the profits of the one and the lord of the soil (has the profits) of the other by (de) the king's grant...'

${ }^{369}$ Ibid 'if anyone's close be broken within the precinct of any leet, this will not be inquired (about) in the leet... because it is not a common nuisance to other common folk...but if a ditch (fosse) or a bridge (pont) be un repaired (ne sont repelle) or cleaned out (mundes), these will be inquired (about)...'.
} 
- $\quad$ Further, general legislation dealt with the highways and removing nuisances. In particular the Highways Act 1562 - specified that hays, fences, dykes and hedges near the highway were to be maintained. And, that bushes and trees growing in the highways were to be cut down.

\section{PULTON (1609), DALTON (1619), COKE (1628-41)}

\section{(a) Pulton \& Dalton}

Pulton, in his De Pace Regis et Regem (1609), ${ }^{370}$ did not consider the law on public nuisance and Dalton, The Countrey Justice (a popular work first published in 1618, which was to continue until 1746) ${ }^{371}$ scarcely did so, only referring to it in the context of abatement. Dalton stated (in the edition of 1619):

Every man in a peaceable manner, may assemble meet company (and may come) to do any lawfull thing; or to remove or cast down any common nusans done to them. ${ }^{372}$ Every private man, to whose house, or land, any nusans shall be erected, made or done, may in peaceable manner, assemble a meet company, with necessary tools, and may remove, pull, or cast down such nusans (and that before any prejudice received thereby) and for that purpose if need be, may also enter into the other man's ground. ${ }^{373}$

Dalton referred to a case in $1593 .{ }^{374}$ However, if violence or threatening words were involved in abating a public nuisance, a crime might be committed. ${ }^{375}$ In respect of this, Dalton referred to a Star Chamber case where persons sought to remove a weir from the river Trent. ${ }^{376}$

\section{(b) $\underline{\text { Coke }}$}

Coke, in his Institutes of the Laws of England (1628-41), ${ }^{377}$ had little to say on the law of nuisance - whether private or public. As to the latter, Coke considered that court leets were of Anglo-Saxon origin (see 3(d)) ${ }^{378}$ and (in a separate work) that courts leet were franchisal. ${ }^{379}$ They belonged to the Crown and were franchised out to lords of the manor, and other important persons, from early times. Coke also noted that the sheriff's tourn (circuit) heard and determined, among other things, common nuisances. ${ }^{380}$ Coke, briefly, considered the law on building ${ }^{381}$ - although he did not refer to the London regulation of 1189 (see 6(a)).

\footnotetext{
${ }^{370}$ Pulton, n 41.

${ }^{371}$ See n 42.

${ }^{372}$ Ibid, p 203

${ }^{373}$ Dalton cited Penruddock's Case (1598) 5 Co Rep 101 (77 ER 210) and Baten's Case (1610) 9 Co Rep 55 (77 ER 810 ).

${ }^{374}$ Dalton cited 36 Eliz (1593) Crompton 66. Dalton stated 'A man erects a weare [weir], cross [across] a common river (where people have a common passage with their boats) and divers did assemble with spades, crowes of iron [crowbars], and other things necessary for to remove the said weare, and made a trench in his land that did erect the weare, to turn the water, so as they might the better take up the said weare, and they did remove the same nusans, this was holden neither any forcible entry, nor yet any riot.'

${ }^{375}$ Ibid, p 203 'But in the cases aforesaid, if in removing any such nusans etc the persons so assembled shall use any threatening words (as to say, they will do it in spite of the other; or they will do it though they die for it, or such like words) or shall use any other behaviour, in apparent disturbance of the peace, then it seems to be a riot:...'

${ }^{376}$ Dalton, n 42, p 204 stated 'One NW together with fourscore [80] persons, came with spades, mattocks, pistols, swords, and daggers, in the night, to a piece of ground (where Sir Thom[as] St, had made a great weir cross over the river of Trent, in the county of Notting[ham] to the great nusance of passengers there etc) and there they made one or two little trenches to let out the water etc. And though it were lawful to make the trenches, and to debruse the nusans, yet for that they came with such numbers and weapons, they were deeply fined in the Star Chamber. 36 Eliz.'

377 See n 43 .

${ }^{378}$ Ibid, vol 2, p 69.The word 'leet' may have derived from the Anglo-Saxon word, laeod, to assemble and was a reference to the court of the people (folkmote). See HB Sheppard, Courts Leet and the Court Leet of the Borough of Taunton (Somersetshire Archeological and Natural History Society, 1909), p 8

${ }^{379}$ See H Hawkins, Three Law Tracts (1764, rep Professional Books Ltd, 1982) containing E Coke, The Compleat Copyholder (first published, 1630), p 51 'court-leets originally belonged unto the king...inferior lords of manors cannot keep court-leets without special prescription, or some special patent from the king... court-leets enquire of all offences, under high treason, committed against the crown and dignity of the king.' Coke, n 43, vol 4, p 265 listed additional statutory nuisances which the court leet dealt with.

${ }^{380}$ Coke, n 43, vol 3, p 259. Ibid, p 263 'The reason wherefore...courts of the tourn and leet are courts of record...is, for that the tourn and leet are instituted for the common-weal, as for conservation of the king's peace, and punishment of common nusances etc.'

${ }^{381}$ Ibid, vol 4, p 200. He stated 'We have not read of any act of parliament now in force made against the excess of building, or touching the order or manner of building... .'
} 
- Coke noted that the common law prohibited the building of any edifice which would result in a common nuisance 382 or cause a nuisance to any man in his house. For example, stopping up his light or other prejudice or annoyance to him; 383

- Coke also noted that - if a person erected a building on his own ground in the king's forest - it was a purpresture which might either be demolished or arrented (i.e. let out at a rent) to the use of the king. ${ }^{384}$

Further,

- Coke noted that keeping a brothel was punishable as a common law crime - citing as the rationale that it was a public nuisance. ${ }^{385}$ However, it is noteworthy that Coke was not suggesting that brothel keeping was punished by the criminal law, twice-over, viz (a) as such; and (b) as part of a generic crime of public nuisance;

- Moreover, in the third volume of his Institutes - which dealt with crimes - Coke did not suggest there was a crime of public nuisance.

Coke also noted that an individual had no civil redress (action on the case) in respect of obstruction of the highway unless he was especially affected. Thus, he stated:

a diversity between a private way...and a common way. For if the way be a common way, if any man be disturbed to go that way, or if a ditch be made overthwart [across] the way so as he cannot go, yet shall he not have an action upon his case; and this is the law for avoiding the multiplicity of suits, for if any one man might have an action, all men might have the like. But the law for this common nuisance has provided an apt remedy, and that is by presentment in the leet or in the torne [tourn], unless any man has a particular damage: as if he and his horse fall into the ditch, whereby he received hurt and loss, there for this special damage, which is not common to others, he shall have an action upon his case; and all this was reserved by the court in the king's bench. ${ }^{386}$

This followed precedent. ${ }^{387}$ As for the highway, in his time, Coke distinguished between:

(a) a foot way;

(b) a foot way and horse way;

(c) a cart way (which also contained the other two)

The 'cartway', Coke considered comprised two elements - the king's highway ${ }^{388}$ and the communis strata (chimin). ${ }^{389}$ That is, the public highway.

\footnotetext{
${ }^{382}$ Ibid, 'the common law prohibits the building of any edifice to a common nusance...'.

${ }^{383}$ Ibid, Coke quoted Deuteronomy, ch 22, v 8 'When you build a new house, make a parapet around your roof so that you may not bring the guilt of bloodshed on your house if someone falls from the roof.'

${ }^{384} \mathrm{Ibid}, \mathrm{p} 204$.

${ }^{385} \mathrm{Ibid}$, 'the keeping of a house of bawdry or stews, or brothel house, being as it were a common nuisance, is punishable by the common law.'

${ }^{386}$ Coke, $\mathrm{n} 43$, vol 1, s 68 . Coke continued 'And in that case it was said, that it had been adjudged in that court between Westbury and Powell, that where the inhabitants of Southwark had by custom a watering place for their cattle which was stopped up by Powell, that in that case any inhabitant of Southwark might have an action; for otherwise they should be without remedy, because such as nuisans is not presentable in leet or tone [tourn]. Note the diversity.' Coke referred to William's Case (1599) 5 Co 72 (77 ER 163) at p 73a 'for common nuisances which are equal to all the king's liege people [i.e. subjects], the common law has appointed other courts for the correction and reforming of them, scil[icet]. tourns, leets, etc.' See also $5 \mathrm{Edw} 4 \mathrm{pl} 24$ fo 2b, Seipp no 1465.028 (horse stuck in mud due to common way not being repaired).

${ }^{387}$ In a case in 1535 , Fitzherbert J stated 'I agree well that each nuisance done in the king's highway is punishable in the leet and not by action, unless it be where one man has suffered greater hurt or inconvenience than the generality have; but he who has suffered such greater displeasure or hurt can have an action to recover the damage which he has by reason of this special hurt. So if one makes a ditch across the highway, and I come riding across the way in the night and I and my horse are thrown into the ditch so that I have great damage and displeasure thereby, I shall have an action against him who made this ditch across the highway, because I have suffered more damage than any other person.' (1535) $27 \mathrm{Hen} 8 \mathrm{pl} 10 \mathrm{f} 27 \mathrm{a}$, Seipp no 1535.074 (action on the case for the obstruction of a Royal road). See also Spencer, n 3, p 73; Ibbetson, n 210, p 106; Newark, n 220, p 483 and Baker, n 20, p 434.

${ }^{388}$ See also a case in 1462, 2 Edw $4 \mathrm{pl} 21$ fo 9a-9b, Seipp no 1462.021 (trespass for breaking close and trampling grass). Seipp Commentary ' Sjt Littleton (for D): the road is the king's, but the freehold is yours (plaintiff's), because if a tree be growing in the road, you have it, so, etc. Moyle JCP: I deny your case of the tree, because I say clearly to my thinking the freehold is the king's, because if any encroachment (purpresture) be made onto (oust') the road, as a ditch (fosse), a house (mes.) or a wall (ou mur') he will be punished in the tourn, or in the leet, if it be in the hand of another person, and it will be supposed 'to the nuisance of all the people of the lord king' ( $A d$ nocumentum totius populi domini regis); I say as before that the freehold is the king's, and the punishment for encroachment (purpresture) is the king's, and the termor through whose land the road goes cannot plow (arer) the land, and Sir, I put that a house be built on the road, who will have it?, I say that the king (will have the house) and no one else, so this proves, etc. (which was not answered), query if there was a distinction between raising a house and a tree growing.'
} 
- $\quad$ This reflected no change to the Laws of Edward the Confessor (c. 1140s)(see 3(c)) where similar reference was made to the king's highway and the public highway;

- However, the former, by this time was, really, a misnomer since - pursuant to the Highways Acts 1555 and 1562 taxation of the public (and not the Crown) was maintaining most highways (with the four Royal highways being treated no different to others). ${ }^{390}$

As to what constituted an obstruction, when commenting on the Statute of Bigamy 1276 , chapter (section 4), ${ }^{391}$ Coke defined a purpresture (encumbrance), stating:

Purprestura comes of the French word purprise, or pourpris, which signifies an inclosure or building, and in legal understanding signifies an encroachment upon the king, either upon part of the king's demesne lands of his crown, which are accounted in law as res publicae, et semper favorabile suit in omni republica principis patrimonium; [public things, and the patrimony of the prince was always favourable in every Commonwealth] or in the highways, or in common rivers, or in the common streets of a city, or generally when any common nusans is done to the king and his people, endeavouring to make that private, which ought to be public. ${ }^{392}$

\section{(c) $\underline{\text { Bridges }}$}

A word may be said on bridges. As well as it being a nuisance to fail to maintain (repair) the highway, it was also a nuisance to do so in respect of bridges, their being treated, effectively, as part of the highway. In respect of this:

- $\quad$ Anglo-Saxon Times. Bridges - being part of the highway and essential for military purposes - in Anglo-Saxon times it was part of the trinoda necessitas to repair them. ${ }^{393}$ This continued obligation of trinoda necessitas was mentioned in the Laws of Henry I (c.1113)(see 4(b));

- $\quad$ 12th Century Onwards. Likely, the ability of sovereigns to enforce the trinoda necessitas began to fail by the 12th century in respect of bridges. ${ }^{394}$ Thus - in the case of those not directly maintained by the Crown - the Crown granted a franchise to cities, towns and individuals to impose a toll - which was called bridtoll (variant spellings), and, later, pontage - for their repair and maintenance; ${ }^{395}$

- $\quad$ Act of 1530. Despite pontage, bridges were, often, from medieval times in a poor state - with no one wanting to take responsibility. An Act of $1530{ }^{396}$ therefore - one which applied to public, but not private, bridges ${ }^{397}$ imposed a duty on JP's to determine who was legally responsible for the repair of the bridges in their county. If no one, the relevant justices of the peace were empowered to impose a tax on the inhabitants (of a reasonable sum) for

\footnotetext{
${ }^{389}$ Ibid 'this is twofold, viz. regia via, the king's highway for all men, et communis strata, belonging to a city or town, or between neighbours and neighbours. This is called in our books chimin, being a French word for a way...' For his part Powell (in 1668), n 134, p 83 defined the highway into the chimini majores (the 4 great ways, see $\mathrm{n}$ 108) and the chimini minores ('such which lead from city to city, and from one town to another.'). Cf. Holdsworth, n 59, vol 7, pp 336-7.

${ }^{390}$ The legal merger of the king's and the public's highway accelerated with the Civil War (1642-9) in which the concept of 'the people' (the public) increased. In the City, Chew, n 152, pp xxviii-ix, noted that reference to 'common soil' occurred early on, stating: 'The arrentation of purprestures was probably never very profitable to the Crown and in any case, after 1341 there were no further London sessions of Crown pleas at the Tower. There was then nothing to inhibit the idea that the commonality owned the streets and lanes. Thus, it is striking that the phrase solum communitatis first appears on our rolls in 1344 when a [D] is charged with having built upon the commonality's soil next to the City Wall within Newgate...'

${ }^{391}$ Coke, n 43, vol 2, pp 271-2. The Statute of Bigamy, ch 4 stated: 'Concerning purprestures, or any manner of usurpations, made upon the king within franchises, or elsewhere, it was agreed and determined in the time of king Henry [Henry II, 1154-89], that where such usurpers were living, the king should re-seise of new the land so usurped out of the hands of the usurpers; the which thing also shall be from henceforth observed in the realm; and if any do complain upon such re-seisers, he shall be heard like as right requires.'

${ }^{392}$ See also $n 113$.

${ }^{393}$ The obligation does not seem to have been to build them. See also Coke, n 43, vol 2, p 701 'None can be compelled to make new bridges, where never any were before, but by Act of Parliament.' He referred to the Laws of Canute (c. 1035), see Robertson, n 20, p 207 'If anyone neglects the repair of fortifications or of bridges or military service, he shall pay 120 shillings as compensation to the king in districts under English law, and in the Danelaw the amount fixed by existing regulations...' .

${ }^{394}$ An explanation for this is not hard to find. A person could a pay a fine, to avoid having to repair a bridge. It was called bridgebot. See Fleta, n 26, p 102 'Bridgebot, quittance of the duty of repairing a bridge.'

${ }^{395}$ See generally, GS McBain, Abolishing some more Obsolete Crown Prerogatives (2011) Liverpool LR, vol 32, no 1, pp 68-74. It was said the first grant of pontage by the Crown was made in 1228 (for Ferrybridge near York). However, it likely existed before then. Ibid, p 72. In the case of the defensive walls of cities and towns, the toll was called 'murage. Ibid.

${ }^{396} 22$ Hen 8 c 5 (1530, rep 1959). See also Coke, n 43, vol 2, p 697.

${ }^{397}$ Coke, $\mathrm{n} 43$, vol 2, p 701 'This [Act] extends only to common bridges in the king's high-ways, where all the king's liege people have, or may have passage, and not to private bridges to mills, or the like.'
} 
repairing the same. ${ }^{398}$ The highway up to the bridge (up to 300 feet) was also to be repaired. ${ }^{399}$ Coke noted the rationale for this tax. It was imposed on the whole county for the common good. ${ }^{400}$ This connection between the bridge and the public (king's) highway is important when considering modern public nuisances that occur on bridges which span motorways or connect the highway (see 33(c)).

In conclusion, Coke said little on the law of nuisance. However, there would appear no evidence, in the criminal context, that Coke supported the idea of a generic crime of public nuisance.

\section{KITCHIN (1653) - ROLLE (1668)}

\section{(a) Kitchin (1653)}

In 1653, Kitchin published the second English edition (the first was in 1651) of his Jurisdictions or The Lawful Authority of Courts Leet etc. ${ }^{401}$ In respect of the charge of the leet, after discussing serious crimes which the court leet inquired into but did not judge, Kitchin considered the:

residue of the matters of the charge which ensue, are inquirable and presentable, and also punishable in a leet. ${ }^{402}$

Kitchin listed 45 points. These included statutory nuisances - ${ }^{403}$ such as eavesdroppers (see Statute of Westminster 1275), ${ }^{404}$ nightwalkers (see Statute of Winchester 1285) ${ }^{405}$ selling unwholesome food (see Statute of the Pillory c. 1266) ${ }^{406}$ and scabbed horses (see Act of 1540). ${ }^{407}$ Kitchin also mentioned keeping a bawdy house. ${ }^{408}$ And, the crime of being a common scold ${ }^{409}$ which was (probably) a statutory nuisance. In respect of other nuisances, Kitchin referred to the following (I use his numbering):

\footnotetext{
398 'Be it enacted...that [JP's] in every shire of this realm, franchise, city, or borough...shall have power and authority to enquire, hear, and determine in the king's general sessions of peace, of all manner of annoyances of bridges broken in the high-ways, to the damage of the king's liege people, and to make such process and pains upon every presentment afore them for the reformation of the same, against such as own to be charged for the making or amending of such bridges, as the king's justices of his bench use[d] commonly to do, or as it shall seem by their discretions to be necessary and convenient for the speedy amending of such bridges...'. Also, [JP's] shall have power and authority to tax, and set every inhabitant in any such city, town or parish...to such reasonable aid, and sum of money, as they shall think by their discretions convenient and sufficient for the repairing, re-edifying, and amendment of such bridges...' The JP's also had the power to appoint surveyors.

399 '[JP's]...shall have power and authority to enquire, hear, and determine in the king's general sessions of peace, all manner of annoyances of in such high-ways, so being and lying next adjoining to any ends of bridges within this realm, distant from any of the ends of such bridges, three hundred foot, and to do in every thing and things concerning the making, repairing, and amending of such high-ways, and every of them, in as large and ample manner as they might and may do, to and for the making, re-pairing, and amending of bridges, by virtue and authority of this present Act.'

${ }^{400}$ Coke, n 43, vol 2, p 700 'But admit none at all were bounden to the reparation of the bridge...the whole county shall repair the same; for of common right the whole county must repair it, because it is for the common good, and ease of the whole county.'

${ }^{401} \mathrm{~J}$ Kitchin, Jurisdictions or the Lawful Authority of Courts Leet (2nd ed, 1653). This text was, originally, in law french, the first edition of which was J Kitchin, Le Court Leets et Court Baron (1st ed, 1589).

${ }^{402}$ Ibid, p 19.

${ }^{403}$ e.g. '23. Also if any by any way corrupt the common waters, by whitening, by lime, or by flax, or stuff laid in the waters, by which the waters are corrupt, it is inquirable....24. Also, if any has, or used any false measures, of bushels or gallons, yard or ells, or false weights or balances, are inquirable... 25. Also if any use double pounds or measures, that is to say, a small one to sell by, and a great one to buy by, in deceit of the people, it is inquirable... 26. Assize of Bread and Beer, that this be held scilicet, that everyone sell according to the price of corn, is inquirable, and that it be made wholesome for men... 27. Also if tiplers sell by cups and dishes, or measures sealed, or not sealed, is inquirable....etc.'

${ }^{404}$ e.g. '17. Also if any eave droppers, which stand under walls or windows, by night or day to hear tales, and to carry them to others, to make strife and debate among their neighbours, present their names.'

${ }^{405}$ e.g. 20. Also if there be any vagabonds or wanderers, and those which walk by night, and sleep by day, and if there be any which are the common haunters of taverns or alehouses, and go about, and having nothing to live of, are inquirable, $4 \mathrm{H} 7 \mathrm{fol} 2$. In leet is inquirable of night walker.' The reference is to 4 Hen $7 \mathrm{pl} 2$ fo 1b-2a, Seipp no 1489.002 (1489)(trespass for assault and battery).

${ }^{406}$ eg. '29. Also if butchers, fishmongers, or other victuallers sell any corrupt victual not wholesome for mens bodies, it is inquirable.' See also The City Law (London, 1658), p 4 'Item, the mayor and aldermen have always used to make penal Ordinances upon victuals, and for other the government of the said City and of the peace, according to their discretion and advice, and to proclaim the said Ordinance within the said city openly for to be held and kept in the name of our sovereign lord the king, and of the City, upon pain therein ordained...'

${ }^{407}$ e.g.' 41. If any horse or mare be put upon the common and be scabbed, or having an infectious disease, he shall forfeit to the lord of the manor ten shillings.' 32 Hen 8 c. 13 (1540)(An Act for Breed of Horses), s 7 stated that no diseased horse with scab or mange was to be brought into any forest, chase, moor, marsh, heath, commons, waste ground or common fields. The fine was $10 \mathrm{~s}$ and the offence was inquirable in 'every leet, as other common annoyances be.' See also Powell (in 1668), n 134, pp 155-6.

${ }^{408}$ e.g. '19. Also if any keep and maintain any bawdry in their houses, it is a cause to break the peace, and is a vice which corrupteth the commonwealth, and for that it is here inquirable...'.
} 
6. Also, if any annoyances be made upon the land, wood and water, that blocks, stocks, ditches. hedges, made, or a ditch made, or filled to the annoyance of the people, or if any other thing be done to the annoyance of the people, that is to the multitude, and not only to one, is inquirable. $18 \mathrm{Edw} 2 \ldots$

7. Also, if any walls, houses, pales [fences], or hedges be made or erected to the noyance of the people, it is inquirable. $18 \mathrm{Edw} 2 .$.

8. Also, if any common ways, waters, ditches, or paths are turned out of their right course, it is inquirable. $18 \mathrm{Edw}$ 2.

9. Also if any bounds are streightened, or carried away. $18 \mathrm{Edw} 2 \ldots$

10. Also if lay stalls [dung hills] are made in highways to the noyance of the people, or if any carrion be cast into the highway to the noyance of the people, it is inquirable. ...

11. Also if any make any encroachment upon the king's highway...

18. Also if any be common breakers of hedges, present their name. ${ }^{410}$

The references to '18 Edw 2' is to the View (Statute) of Frankpledge c.1325 (see 13(a)) which gave the court leet jurisdiction over such matters. Kitchin's list was no different in purport to that of Adames (see 13(b)), save that it added some more statutory nuisances. It may also be noted that Kitchin - at no time - asserted there was a generic crime of public (common) nuisance.

\section{(b) Sheppard (1654)}

Sheppard, Court-Keepers Guide ${ }^{411}$ - the first edition of which was in 1649 - dealt, inter alia, with the court leet. (I cite the 3rd edition in 1654). Sheppard described the court leet. ${ }^{412}$ Noting that it could not 'meddle with any offence against a statute law, except the statute give it power so to $d o^{\prime}{ }^{413}$ - and after dealing with various Crown franchises such as treasure trove, waif, estray etc. - under a side note 'Common nuisances' Sheppard referred to:

All common and popular nusances or grievances done to the king's subjects, by purprestures made in any land, wood, or water; by walls, hedges, ditches, or houses made up or broken down: by straitening, turning, stopping, surrounding, or otherwise hurting the common ways, bridges or waters: by poisoning or corrupting the air, ${ }^{414}$ by the laying of any carrion or filth, setting up of houses of office, ${ }^{415}$ or the like: or by the selling of corrupt and unwholesome provision: or by the breaking of the due Assise of bread, beer etc [or] by cottages and inmates; ${ }^{416}$ by no[t] scouring ditches or not repairing highways and bridges and the like. ${ }^{417}$

\footnotetext{
${ }^{409} \mathrm{eg}$. '13. Also if there be any common barretors in the lordships, as scolds, brawlers, to the noyance and disturbance of their neighbours, present their names.' See also The City Law (London, 1658), p 5 'Item, the mayor and aldermen have always used to cause to come before them the malefactors which have been taken and arrested within the said city, for carrying of tales, and spreading abroad of news imagined in disturbance of the peace... and those which they have found culpable of such misdeeds by confession of the parties, or by inquest thereof made, shall be punished by setting in the pillory, or further chastised by imprisonment, according to their merit, and according to the reasonable discretion of the said mayor and aldermen.'

${ }^{410}$ Ibid, pp 19-20. For a similar list see Powell (in 1668), n 134, pp 81-2 which he said included 'If any encroach upon the king's high ways, or any carrion or unwholesome thing be cast into the same, or in the common streets to the annoyance of the people. If any bridges or causeys be decayed or broken, inquiry is to be made of the defects, and who ought to repair them.'

${ }^{411}$ W Sheppard, Court-Keepers Guide or a Plaine and familiar Treatise needful and useful for the help of many that are imployed in the keeping of lawdayes or Courts Baron (1st ed, 1649; last ed 1685).

${ }^{412} \mathrm{Ibid}$, pp 3-4 'The leet (called also a lawday and a view of frankpledge) is an ancient court of record, instituted for reformation of public offences or Crown matters within the precinct thereof, after the example of the sheriff's turne [tourn]. For the leet is derived out of the sheriffs turne and is holden before the steward as judge; who has (except in some few things) the same power for the compass and reach of its jurisdiction, which the sheriff has in his turne for the whole county.'

413 Ibid, p 11.

414 This was one of the first references to air. Being 'common', an annoyance to it was treated as a common nuisance.

${ }^{415}$ i.e. a privy.

${ }^{416}$ A statutory crime, see 13 Eliz c. 7 (1589). Also, Hearnshaw, n 134, p 129 (no one shall erect a cottage without attaching to it four acres of land).

${ }^{417}$ Sheppard, $n$ 411, pp 12-3. Sheppard continued 'And for all these the offender (be he one man or a whole parish) may be amerced and the jury may order, the reforming of them under a pain. But for private or particular nusances to persons or places, this court has not to do with them.' See also pp 44-9 (charge). Powell (in 1668), n 134, p 87 'All common or popular nusances done to diverse and sundry of the king's subjects, are inquirable at this ancient court, and so are all trespasses at the common law being popular.'
} 
This is a hotpotch and Sheppard failed to indicate exactly which of these were statutory (such as the Assizes) and which were common law nuisances. ${ }^{418}$ The failure to do so did not assist with the law since, in a later case, Thomas $v$ Sorrell (1673), ${ }^{419}$ Vaughan CJ (in the context of what laws the sovereign could dispense with) referred to:

nuisances at common law...as obstructing the highway, diverting a water-course, breaking down a bridge, breaking the assize of bread and ale... ${ }^{420}$

However, the Assizes of Bread of Ale were statutory and the others were, generally, treated as statutory given that the Statute of Wales 1284 and the View of Frankpledge c. 1325 were treated as placing in statute older common law crimes. ${ }^{421}$ Sheppard also noted that a matter could not be presented (prosecuted) in the court leet unless it was a common (as opposed to a private) nuisance. ${ }^{422}$ His version of the charge of the leet stated, after listing various nuisances:

These are common nuisances, whereof you are to inquire and present. And for these the offender may be amerced, and an order may be made under a penalty to reform it: and if it be a standing nusance by a house or wall, it may be pulled down; but for every one of these nusances, being malum in se, and against the common law, the offender may be amerced according to your discretion, or where any statute has appointed a special penalty... ${ }^{43}$

In his charge, Sheppard was not suggesting there was a generic offence of public nuisance. Rather, he described a list of specific nuisances as common nuisances which the court leet had jurisdiction to deal with. However, the wording of Sheppard is loose and his sidenote reference to 'common nuisances' does not help - which may have led later writers such as Hawkins (see 17) to assert a crime of common nuisance at common law. It may be noted that Sheppard was not, generally, highly rated as a legal writer. ${ }^{424}$

\section{(c) $\underline{\text { Star Chamber (1641) }}$}

In the context of public nuisance, brief reference may be made to the Star Chamber, which was abolished in $1641 .{ }^{425}$

- An accurate picture of its caseload in criminal matters is difficult to determine in the absence of full records ${ }^{426}$ and those which exist suggest little involvement in matters relating to public nuisance, ${ }^{427}$ save in respect crimes committed in abating the same; ${ }^{428}$

\footnotetext{
${ }^{418} \mathrm{Ibid}, \mathrm{p}$ 14. Sheppard also referred under the side note 'Evil members or persons of ill behaviour' (the description was his own creation) to: 'Evil members, and persons of ill behaviours that are dangerous to their neighbours as malefactors in parks, such as take doves by engines [i.e. traps], such as are common suspected thieves, or that are the common messengers of thieves, the common drunkards, the common hanters [haunters] of alehouses or taverns, not having whereon to live night-walkers and daysleepers, that live idlely, have no estate, and yet fare well, evesdroppers, common hedge-breakers, common peace-breakers, raylers and sowers of discord between neighbours, keepers or haunters of bawdy houses, common scolds, common barretors, common usurers, innkeepers who do commonly entertain thieves and suspicious persons, knowing or suspecting them to be so, and such as do remove bounds or land-marks between parishes, hundreds or counties; but not such as remove bounds between persons only.'

${ }^{419}$ Vaughan 330 (124 ER 1098).

${ }^{420}$ At $\mathrm{p} 335$. See also $\mathrm{p} 339$. Vaughan CJ also thought forestalling was a nuisance at common law, when it was statutory, see text to n 264 .

${ }^{421}$ See 10.

${ }^{422}$ Ibid, p 21 'If it be of a nuisance, it must say, to the common nusance of the people.' Ibid, p 33 'this court [court leet] is a power for the redressing and reforming of public wrongs to the whole body of the common weal; of public wrongs I say, for private and personal matters simply. First wrongs between man and man, whether by force or fraud, are not herein equitable, but for them the county court and hundred is properly appointed; and therefore all such presentments as are only of a wrong to some men or place alone are void. So that by this we see that we have the same power here that the sheriff has in his tourn, unless it be in some special cases: and the nature both of this and that court are to inquire and reform public injuries, and such as are against the body of the commonweale [common weal].' Ibid, pp 44-6 (charge of the leet), 'you shall inquire of common annoyances, and popular grievances, $\mathrm{i}[\mathrm{d}][$ id est $]$ of things done to the common grievances of many: For as to the particular grievance of one man, or special grievance of one parish, you are not to inquire in this court; but that which is, or may be general, and to many persons and places.'

${ }^{423}$ Ibid, p 46

${ }^{424}$ Thus, W Sheppard, The Touchstone of Common Assurances ( st $^{\text {ed }}, 1648$; last ed $\left(8^{\text {th }}\right.$ ed), 1826) was a popular work on conveyancing. However, the work may, actually, have been that of Doderidge J, the manuscript of which Sheppard bought after the former's death. See Holdsworth, n 59, vol 5, p 391. It is not of high quality which is, also, the position with regard to Sheppard's Abridgment. Ibid, p 377 ('poor pieces of work').

${ }^{425}$ See e.g. (a) C Scofield, Study of the Court of Star Chamber (1900); (b) IS Leadam, Select Cases before the King's Council in the Star Chamber, SS, vols 16 \& 25; (c) Baildon, n 134; (d) W Hudson, A Treatise of the Court of Star Chamber (1792, rep The Legal Classics Library, 1986); (e) R Crompton, Star Chamber Cases (1630 or 1641, Boston, Soule and Bugbee 1881, rep Law Book Exchange, 2008).

${ }^{426}$ See Tucker, $\mathrm{n} 278$, introduction.
} 
- However, one issue which the Star Chamber dealt with suggests the root of the idea of public nuisance as a distinct crime. By the 16th century, London was expanding rapidly and Elizabeth I (1558-1603), James I (1603-25) and Charles (1625-49) all issued Proclamations to control and restrict building ${ }^{429}$ - in part to deal with the problems of fire and the plague, which resulted from over-crowding. Persons were fined for building contrary to these proclamations and, sometimes, suffered forfeitures.

Hudson, A Treatise of the Court of Star Chamber, ${ }^{430}$ stated that this court:

punisheth errors creeping into the Commonwealth, which otherwise might prove dangerous and infectious diseases, and giveth life to the execution of laws, or the performance of such things as are necessary in the Commonwealth, yea though no positive law or continued custom of the common law giveth warrant to it. Such are all punishments of breach of proclamations before they have the strength of an act of parliament, which this court hath stretched as far as ever any act of parliament did. As 41 Eliz [1598] builders of houses in London were sentenced, and their houses ordered to be pulled down, and the materials to be distributed to the benefit of the parish where the building was; which disposition of the goods foundeth as a great extremity, and beyond the warrant of our laws; and yet surely very necessary, if any thing would deter men from that horrible mischief of increasing that head which is swollen to a great hugeness already. 431

In Solicitor-General $v$ Louche and Holland (1607), a case brought for building contrary to the Proclamations of Elizabeth I (1558-1603) and James I (1603-25), Coke CJ stated that such buildings 'are against the common law and the king's prerogative' - the latter being a reference to the Proclamations. As to the former, this seems to be a clear reference to the civil position, as Coke was to later note in his work (see 14(b)). For his part, Ellesmere LC stated that 'the king's proclamation binds as a law. ${ }^{432}$ However, neither suggested that a person could be fined or imprisoned and his property forfeited for building contrary to a Proclamation on the basis that such building comprised the crime of public nuisance at common law. Further, the Case of Proclamations (1610) held that a Proclamation could not make unlawful what was not unlawful before (which remains the position today). ${ }^{433}$

- That said, Star Chamber cases such as $A-G v$ Ward (1628), $A-G v$ Moore (1634), as well as a decree of the Star Chamber in $1637,{ }^{434}$ suggested that the legal right to fine and imprison for breaching the building regulations in these Proclamations was due to the fact that they comprised a common nuisance at common law;

- $\quad$ Thus, a Decree of 14 February 1637 appears to have asserted - pursuant to a 'general resolution' of all the judges of the common law - that new buildings on new foundations in London (with the dividing of tenements) was ' $a$ most unsufferable annoyance against the public, and consequently is against the common law of the realm; and that not only the said evil conditioned inhabitants, but such by whom, or by whose means they are placed there, or who receive the rents of such inhabitants, are guilty of a common nuisance. ${ }^{435}$

In an article, Barnes took this as (in effect) the transposition of the private law of nuisance into the criminal field, by creating a new crime of common nuisance. ${ }^{436}$ However, the issue is not wholly clear. ${ }^{437}$ In any case, the Star

\footnotetext{
${ }^{427}$ Spencer, n 3, p 61 quoted Hudson (see n 425, p 107) and then referred to the role of the Star Chamber with regard to the crime of public mischief, suggesting that, in respect of public mischief and public nuisance, $\mathrm{p} 62$, 'the contents of the packages are almost interchangeable'. However, the caselaw on public mischief suggests that it was little more than a modern term for the old crime of 'cheat' as opposed to public nuisance, see 34.

${ }^{428}$ See e.g. Dalton, 14(a).

${ }^{429}$ TG Barnes, The Prerogative and Environmental Control of London Building in the Early Seventeenth Century: Tbe Lost Opportunity (1970) California LR, vol 58, pp 1332-63, especially, pp 1337-8.

${ }^{430}$ Baildon, n 134, pp 328-9. Also, p 318, Savage (1606). See also Barnes, n 429, p 1347.

${ }^{431}$ Hudson, n 425, pp 107-8. Barnes, n 429 p 1344 'The first report of a trial in Star Chamber for violation of the proclamation against building dates from 1598. The [A-G] prosecuted John Crypse of Middlesex and Richard Griffith of London for building tenements in London against the proclamation. To the 'good example' of others, they were sentenced to a fine of £20 each, imprisonment at the Queen's pleasure, their tenements to the demolished after the present tenants had left them, and the timber of the houses to be sold for the aid of the poor of the parish. They were also bound with sureties in $£ 40$ to perform the sentence of the court. From the vantage point of the last decade of building control, this case and the decree in it constituted the springing point for all subsequent Star Chamber prosecutions.'

432 Baildon, n 134, p 329.

${ }^{433}$ Barnes, n 429, p 1357. See also Case of Proclamations (1610) 12 Co Rep 74 (77 ER 1352). There is no doubt the legal attitude towards Proclamations (as with their forebearer, Ordinances) changed considerably over time and, in the case of Proclamations, especially so in the reign of Charles I (1625-49). See generally, GS McBain, Expanding Democracy - Transferring the Crown Prerogative to Parliament (2014) Review of European Studies, vol 6, no 1, pp 38-43.

${ }^{434}$ Ibid, pp 1350, 1352-3 and 1359 .

435 Ibid, p 1359.

${ }^{436}$ Ibid.
} 
Chamber was abolished in 1641 (and the building proclamations also seem to have become a dead letter). ${ }^{438}$ Further, later legal writers such as Sheppard (see (b) above) and Hawkins (see 17) did not use this Star Chamber caselaw or material to argue that there was a generic crime of public nuisance. Indeed, it is asserted that Sheppard was not asserting there was such a crime in any case.

\section{(d) Calthrop (1670)}

By the 17th century, the wardmote system in London was in decay (mainly, one suspects, as a result of the increase in population). Sir Henry Calthrop(e) was a recorder of London in 1635. In 1670 - in an effort to clarify what the London wardmote should deal with - he gathered together (what he said) were the 'Ancient Customs and Usages of the City of London.' 439

- $\quad$ Powers of Mayor \& Aldermen. Among these customs Calthrop noted that the mayor and aldermen had the power to punish (with the pillory or imprisonment) those who spread 'lies' or 'false news'. This likely included common scolds (if the latter was not otherwise treated as a part of barratry, see 12(e)). ${ }^{440}$ The mayor and aldermen could also require the inhabitants to repair buildings and - if unwilling - have City personnel undertake the same, at the latter's cost; ${ }^{441}$

- $\quad$ Articles of the Wardmote. Calthrop also set out, inter alia, the articles of the Wardmote. These were extensive and contained, in respect of nuisances, provisions on: (a) keeping the streets clean; ${ }^{442}$ and (b) taverners not to permit bawdry, lechery, dice playing ${ }^{443}$ or prostitutes in their taverns. ${ }^{444}$ Further articles ${ }^{445}$ contained provisions on: (a) nightwalkers; ${ }^{446}$ (b) prostitutes and common scolds; ${ }^{447}$ (c) casting rubbish in the Thames or other rivers; ${ }^{448}$ (d) pigs and other animals in the streets; ${ }^{449}$ (e) purprestures; ${ }^{450}$ (f) diverting highways or waterways; ${ }^{451}$ (g) defective pavements; ${ }^{452}$ (h) unwholesome food. ${ }^{453}$ Also, there were 'Statutes of the Streets of the City' (of uncertain date)

\footnotetext{
${ }^{437}$ One would suggest the cases can also be read as upholding Proclamations of building as a form of legislation and that arguing that the rationale for suppressing such building was that it was a common nuisance. This avoided the more delicate point of whether there existed at common law a generic crime of common nuisance.

${ }^{438}$ Barnes, n 429, p 1362.

${ }^{439}$ Ancient Customs and Usages of the City of London gathered by Sir Henry Calthrope, see 80 ER 677.

${ }^{440} 80$ ER 677 at 682 'the mayor and aldermen have always used, and may by custom of the same City cause to come before them the offenders which are taken within the said City for lies and false news noised abroad in disturbance of the peace makers...and for other notorious deceits known to them...and punish them by the pillory or other chastisement by imprisonment, according to their discretion.'

${ }^{441}$ Ibid, p 686 'if walls, penthouses, or other houses whatsoever within the said City stretching to the High Street, be so weak and feeble, that the people passing by mistrust [i.e. fear] the peril of some sudden ruin, then the...mayor and aldermen shall cause the parties to...amend them, and repair them.' If not done within 40 days, they could be repaired by the City who then levied the cost on the relevant inhabitant ('of his goods and chattels or other his tenements if need be).'

${ }^{442}$ Ibid, p 690, no 14, the streets and lanes were 'from time to time to be kept clean.' See also no 19.

${ }^{443}$ Ibid, no 15 , no huckster of ale or beer 'shall keep no bawdry, nor suffer no lechery, dice playing, carding [playing cards], or any other unlawful games, to be done, exercised, or used within their houses.' For the meaning of 'Huckster, see n 301.

${ }^{444} \mathrm{Ibid}$, no 22 , no taverner etc to allow 'any common woman of their bodies, or harlots to resort and come into their said house....upon pain of imprisonment'.

${ }^{445}$ Ibid, pp 693-7.

${ }^{446}$ Ibid, no 5 'if any man be a common riotor, or a barrator walking by nightertale [i.e. in the night] without light, against the rule and custom of this City.'

${ }^{447} \mathrm{Ibid}$, no 10 'inquire of any putour, that is to say, man baud, or woman baud, [i.e. pimp ] common hazerdours, [i.e. gamblers] contectour [a contentious person], maintainer of quarrels, champartours, or embracers of inquests, or other common misdoers be dwelling within this ward.' Also, no 11 'if any bawd, common strumpet [prostitute], common adulterer, witch or common scold be dwelling within this ward.' Also no 12 (if any hothouses (bathhouses) to which common strumpets resort)

${ }^{448}$ Ibid, no 14 'if any manner of person cast dung, [and other rubbish] in the river of Thames, Walbrook, Fleet, or other ditches of this City; or in the open streets, ways, or lanes within this City.'

${ }^{449} \mathrm{Ibid}$, no 16 'if any manner of person nourish or keep hogs, oxen, kine [cattle], ducks or any other beasts within this ward, to the grievance and disease of their neighbours.'

${ }^{450} \mathrm{Ibid}$, no 24 'if any man make purprestures, that is to say, incroach, or take of the common grounds of this City, by land or by water, as in walls, pales, shops, grieces [steps] or doors of cellars, or in any other like within the ward, or if any porch, penthouse or jetty be too low, in letting of men that ride beside, or carts that go thereforth.' Also, no 25, 'that penthouses and jetties be at least the height of nine foot, and that the stalls be not of two foot and a half in breadth, and to be flexible or moveable, that is to say, to hang by icmewes or garnets [hinges], so that they may be taken up or let down.'

${ }^{451}$ Ibid, no 26 'if any common way or common course of water be foreclosed or letted, that it may not have his course as it was wont, to the noyance of the ward, and by whom it is done.'

${ }^{452}$ Item, no 27 'if any pavement be defective, or too high in one place, and too low in another, to the disturbance of riders and goers thereby, and carts that go thereupon.'

${ }^{453}$ Ibid, no 31 'if any victualler sell any victuals not convenable [suitable, proper] or unwholesome for man's body...'
} 
which contained provisions on: (a) casting carrion in the streets; ${ }^{454}$ (b) biting curs and mad ${ }^{2}$ ogs; ${ }^{455}$ (c) blowing horns; ${ }^{456}$ (d) nightwalkers and eavesdroppers; ${ }^{457}$

- Act of 1662 on Street Cleansing. ${ }^{458}$ Finally, an Act of 1662 which applied to the City, Westminster and the suburbs (as well as the borough of Southwark) inter alia, gave justice of the peace power to convict and impose penalties for the 'mending and cleansing' of the streets (including paving and lighting, by means of lighted candles), as well as to impose taxation on the inhabitants for the same. ${ }^{459}$

The result of all this is that:

- the Ordinances of 1277-85 (see 11) were supplemented, from time to time, by subsequent Ordinances (also called Articles, Assizes and Statutes) of the Common Council of the City. Finally, by 1662, general legislation was introduced to deal with street cleansing. Enforcement in all cases was via the wardmote courts - albeit, these courts were in considerable decline by 1662 ;

- the Ordinances were likely replicated in many cities and towns which, by charter, were given similar rights to that of the Common Council of the City to make byelaws. An example is Taunton. ${ }^{460}$ In due course such matters were dealt with by local legislation. ${ }^{461}$

\section{(e) $\underline{\text { Rolle }}$}

Rolle, in his Abridgment (1688), had a heading 'nusans' under the general heading 'indictment'. In this, he assembled what Spencer termed a 'heterodox collection of bits and pieces which the judges at one time or another had ruled were indictable offences at common law.' ${ }^{462}$ Thus, Rolle referred to:

(i) concealing treasure trove; ${ }^{463}$

(ii) digging up a church wall; 464

(iii) making off with the property of a royal foundation (by withholding rent); ${ }^{465}$

(iv) stopping up a highway. ${ }^{466}$

Rolle also cited cases distinguishing between private and public nuisance. As it is: (i) is not an example of a public nuisance (and the case cited does not suggest it was). It was a distinct crime - one of considerable antiquity. ${ }^{467}$ In the case of (ii), the facts are unclear. If it was private property and not part of the highway, it was

\footnotetext{
${ }^{454}$ Ibid, p 701. See no 2 'No man shall cast or lay in the streets dogs, cats; or other carren [carrion]...'. Ibid, p 17 'No man shall have any kine, goats, hogs, pigs, hens, cocks, capons, or ducks in the open street, under pain of forfeiture of the same.'

${ }^{455}$ Ibid, no 18 'No man shall maintain any biting curs or mad dogs in the streets.' The term 'cur' was used to describe ill bred or snappish dogs, see OED, n 4 (cur).

${ }^{456}$ Ibid, no 22 'No man shall blow any horn in the night within this City or whistle.'

${ }^{457}$ Ibid, no 24 'That nightwalkers, and evesdroppers, indure [endure] like punishment.'

45814 Cha 2 (1662) c 2 (rep 1948).

${ }^{459}$ This is probably the first legislation on requiring householders to put their rubbish out (every Wednesday and Saturday)

${ }^{460}$ Sheppard, n 378, p 33 noted that 'the exercise of the powers given to the Corporation [of Taunton] by the charter of 1627 gradually superceded the jurisdiction of the court leet in [matters of nuisance]. He also noted, $\mathrm{p} 36$, that, in 1677, a new charter was granted to the town 'giving the mayor and corporation a wider jurisdiction, consequently there are fewer presentments [in the court leet] from this time...'

${ }^{461}$ Ibid, p 41 'In 1768 the Market House Act was passed, and for good or ill many of the remaining powers of the old court leet were transferred into other hands.'

${ }^{462}$ Spencer, n 3, p 63 fn 32 .

${ }^{463}$ Rolle, n 35, no 1 referring to 27 Edw 3 Lib Ass 19 fo 135a, see Seipp no 1353.144ass (presented that a man had found 100 marks of gold and silver).

${ }^{464}$ Ibid, no 14, see Kingdom's Case (1617)(church in Launston). Rolle noted that the case was not resolved.

${ }^{465}$ Ibid, no 2 referring to 27 Edw 3 Lib Ass 20 fo 135a, see Seipp no 1353.145ass. Commentary of Seipp ' It was presented that J. of H. had withheld from the Prior and Covent of M. five shillings of rent for a certain time, and they said that the house was of the foundation of the king. The defendant said that withholding of rent was supposed by the presentment, of which an action was given by suit at the common law, as by Assize or in another manner. Therefore he did not understand that the court would compel him to answer to this presentment. Shareshull CJKB said that it was presented that this house was of the foundation of the king, and the common course of this court (ce' place) was to inquire of such matters withheld from houses that were of the foundation of the king, and further if the king had sent them a special command to do this. Therefore answer. The defendant said that for a similar reason it would be inquired if one had disseised them of their freehold. Shareshull CJKB said, (Latin begins) It is not similar, and he did not say the reason. (Latin ends).'

${ }^{466}$ Rolle, n 35, no 15 referring to 32 Ed 3 (1358), rot 15 \& 23 (removal of nuisance on highway at own cost).

${ }^{467}$ Fleta, $\mathrm{n} 26$, vol 72, p 99 'There is also a certain kind of crime, which presumes evildoing, not, however, involving death but confinement in prison and heavy ransom, and this the fraudulent concealment of treasure trove.' This followed Bracton (c 1240), n 24, vol 2, p 338 'There is...a serious contempt against the king and his crown and dignity which partakes of the nature of the crime of theft, namely, the fraudulent
} 
a private nuisance. Certainly, today, the element of 'publicity' (ad commune nocumentum) - annoyance to the general public as opposed to the church authorities - is not present. And, in the case of (iii), public nuisance does not appear to have been pleaded. For present purposes, however, it is sufficient to note that Rolle was not asserting that there was a generic crime of public nuisance.

\section{(f) Decline of the Court Leet}

It may also be noted that courts leet were in decline by the 16 th century - if not before. ${ }^{468}$ An example is Norwich - likely, one of the earliest examples of a court leet ${ }^{469}$ where decline in its leets occurred from the 14th century (Hudson, who wrote a text on it, thought the Norwich leets were superfluous by 1403 ). ${ }^{470}$ The Norwich courts leet adopted the London form (that is, of wards and aldermen). ${ }^{471}$ Further, the public nuisances which they (and other courts leet generally) had jurisdiction over were no different to the London wards. As a review of Hudson's text on the Norwich courts leet indicates, the following public nuisances were the most common:

(i) Obstructions to the highway and rivers - often, by putting rubbish in it or by placing things such as barriers, steps outside doors etc;

(ii) Breaches of the Assizes of Ale and Measures. The fines became so small that often alewives (who brewed the ale) ignored the Assizes and simply paid the fines;

(iii) Selling unwholesome food;

(iv) Forestalling. ${ }^{472}$

Offences such as nightwalking (night roving) was more rarely mentioned at the Norwich leets and there seems to have been nothing on common scolds. It may also be noted that the crimes dealt with at the Norwich courts leet were few. Likely, this was not just due to the functions of the leet being superceded by other bodies. Adult males were under a duty to disclose crimes. Given this, one imagines they would be unwilling to cause disputes with neighbours unless they could not be solved otherwise. ${ }^{473}$

In conclusion, Kitchin, Sheppard, Calthrop and Rolle cited examples of public nuisances. However, the vast majority were statutory and others were separate common law crimes (such as concealing treasure trove).

concealment of treasure trove...' See also O'Brien (Laws of Edward the Confessor, c. 1140), n 21, p 173 'Treasures from the earth are the king's, unless they shall be found in a church or in a cemetary.'

${ }^{468}$ As for frankpledge, Powell (in 1668), n 134, p 18 described it as 'utterly antiquated.' See also H Fellowes, The Laws respecting Copyholds and Court-Keeping (1799), p 5 'in total disuse.'

${ }^{469}$ Norwich had been inhabited in Roman and Anglo-Saxon times. It was a burgh by the time of Edward the Confessor (1042-66), see Hudson, $\mathrm{n} 346, \mathrm{p}$ xiv. The citizens seem to have secured an exemption from serving in leets belonging to the fee of the king's castle in Norwich by 1184 and Hudson thought the Norwich courts leets may have existed since the reign of Henry I (1100-35). As it is, in 1994, Richard I (1189-99) granted the City to the citizens - with the right to choose their own Provost - which may (if not before) have also included the right to conduct their own view of frankpledge and the division of the City into 4 leets. Ibid, pp lxxii-iii. In 1223, the provost was replaced and the government of the City was placed in the hands of 4 bailiffs who presided over 4 leets. Ibid.

${ }^{470}$ Hudson, $\mathrm{n} 346$, p ix 'After [the 14th c] the power of these courts [courts leet] to a great extent passed....It was partly superceded by the general authority of the Municipal Assembly which was organised in the early part of the fifteenth century. This Assembly consisted of twenty-four Aldermen, and sixty Common Councillors under the Presidency of a Mayor and two sheriffs and was supreme in all municipal affairs, including those which had come under the cognisance of the leets. More particularly the twenty-four Aldermen...were in the course of the fifteenth century endued with permanent magisterial authority corresponding to that exercised by the [JPs] in the country districts. Moreover the city sheriffs from the time of their first appointment in 1403 held their tourns as the county sheriffs did. At a later time inquiries were also made by sworn inquests in each of the four great wards (quite independently of the leet inquests) for the purpose of making presentments to the justices at quarter sessions. Nevertheless the leet juries continued to be appointed and made their presentments to the city sheriffs down to at least 1700 , though finally nothing was left for them to deal with but nuisances and unpaved streets and defective weights and measures.' See also pp lxxix-x. Jacob (in 1715), n 333, p 65 'A great many offences relating to the court leet, are punished by the judges at the Assizes, or by the [JP's] at their General Quarter Sessions, and Petty Sessions, which are held very often, and the court leet but seldom.'

${ }^{471}$ Ibid, p x 'the form it [the court leet] assumed in Norwich was copied from the organisation of London. It was the common form which may be found, with a few variations, in almost all the chartered boroughs from the fifteenth century to 1835 , except that Norwich was one of those boroughs which were 'counties of themselves.' See also Tucker, n 278, p 2 'London 's privileges, customs and procedures influenced those of other courts. By 1216, over a dozen boroughs had adopted London's customs directly or indirectly.'

${ }^{472}$ Hudson, n 346, pp 20-32, cites amercements from the leet roll of 1288-9, which are representative of this.

${ }^{473}$ Ibid, p xxxii 'The process of preparation for the annual leet can hardly have been agreeable to any of the parties concerned.' 


\section{PUBLIC NUISANCE BY 1800}

Bracton (c. 1240) had drawn a distinction between public and private nuisance and this continued - only the former being subject to the criminal law.

- Public nuisance was handled by the lowest courts - the sheriff's tourn, courts leet and, in London, the wardmotes. The list of minor crimes they had jurisdiction over had been established in the 13th century - by the Statute of Frankpledge (c. 1325) and the Statute of Wales 1284. Likely, this list derived from the earlier articles of the wardmotes, since these courts seem to have been around at least from 1111 or even earlier;

- In respect public nuisances over which these courts had jurisdiction, these were similar for all three courts. Further, with rare exceptions, they were statutory nuisances, not common law ones. The source of most of them seem to be the Ordinances of Edward I (see 11). Other nuisances punished such as nightwalkers, selling unwholesome food etc were also (likely) statutory.

This leaves two questions. The first is - Were there any common law nuisances? The answer seems to be few, if any.

- Bawdy House. There was keeping a bawdy house (brothel). However, this was a separate crime (indeed, it likely pre-dated all other public nuisances being Anglo-Saxon (see 3(c)). Also, no nuisance, as such, had to be shown;

- Common Innkeeper. There was also a crime of a common innkeeper refusing to provide board and lodging to a traveller. This seems to have been developed by the courts c. $1465 .{ }^{474}$ However, it was a separate crime and no nuisance - as such - had to be shown;

- Common Scold. Possibly, being a common scold was a common law nuisance. However, more likely, it was simply an aspect of the common law crime of barratry. Or, it was a specific London crime that was upheld generally at common law (see 11(e));

- $\quad$ Obstruction of Highway. This was a statutory crime, at least by c.1113. That of stretbreche or street breach (see 4(b)) - even if not one in Anglo-Saxon times (being covered by foresteal). Further, the Statute of Frankpledge (c. 1325 ) and the Statute of Wales 1284 were treated as not only indicating the jurisdiction of the courts leet and the sheriff's tourn but encapsulating in legislation prior common law crimes. In the case of highways - while it (likely) embraced the track alone at first in early times - by the Statute of Frankpledge (c. 1325) and the Statute of Wales 1284 (see 12(a)) it covered any narrowing or hindrance to the highway. This would have included: (a) trees or bushes on the highway; (b) other obstructions on the highway - such as houses, gates or pits in (or across) the highway; (c) not maintaining the ditches by the side of the highway; (d) damaging the bauks (banks) of the highway; (e) throwing rubbish or carcasses into the highway; (f) breaking hedges alongside the highway; (g) altering the course of the highway. Waterways were treated the same.

After the Ordinances of Edward I (see 11), there were few, if any, common law nuisances - with the exception of the common innkeeper refusing board and lodging. In the case of courts leet, additions were statutory. ${ }^{475}$ And - in the case of the London - the Common Council of the City issued Ordinances (also called Articles or Statutes). As it is, many of the City Ordinances as recorded in the Liber Albus in 1419 (see 12(d)), likely, had faded away by 1800 , being obsolete. The same probably applied generally. Thus, the Charge provided by Kitchin in 1653 contains very few public nuisances (see 15(a)). So too, that of Scroggs, The Practice of Courts Leet and Courts Baron (1701) some 50 years later. ${ }^{476}$ He noted that leet jurors gave an oath to enquire of the things listed in the Charge ${ }^{477}$ including the following:

You are to enquire of and present all nusances. A nusance is that which is an annoyance or disturbance to many. It cannot be said to be to one, for it is commune nocumentum. [common nuisance]

\footnotetext{
${ }^{474}$ See GS McBain, Abolishing some Obsolete Common Law Crimes (2009) 20 King's LJ, pp 98-109.

${ }^{475}$ See the list in Hearnshaw, n 134, pp 365-7.

${ }^{476}$ W Scroggs, The Practice of Courts Leet and Courts Baron (London, 1701). Scroggs later became a CJ with an unenviable reputation. However, his text on courts leet was, generally, well thought of.

${ }^{477}$ Ibid, p 3 'The Charge. Gentlemen, I shall not trouble you with a long and tedious repetition of the antiquity of the courts leet, or the jurisdiction of the same: It shall suffice at this time to tell you, that to the manor are appendant two courts, the one called a leet or view of frankpledge, where we have power to enquire of and punish all offences against the peace, and determine matters of controversy between the king and subject...'
} 
Scroggs then referred to: (a) nuisances in the highways; ${ }^{478}$ (b) eavesdropping; ${ }^{479}$ (c) barretors; ${ }^{480}$ (d) bawdy houses; ${ }^{481}$ and (e) unwholesome food. ${ }^{482}$ As with prior writers, Scroggs referred to specific offences. He did not allege the existence of a crime of a distinct generic crime 'public nuisance.' Nor did he suggest that - merely because an act was a public nuisance - it was a crime.

\section{In conclusion, how did the crime of common nuisance arise? One would suggest that the culprit was the legal writer, Hawkins.}

\section{HAWKINS (1716-21) ${ }^{483}$}

Hawkins, A Treatise of the Pleas of the Crown - the first edition of which was in 1716, the last in $1824^{484}$ - was a popular text. Indeed, it was the first modern work on criminal law in that it sought to provide a comprehensive review of all crimes. However, this was at the expense of accuracy. For example, Hawkins tended to 'package' together a number of disparate crimes into a composite one - even though no court (or judge) had done this. Thus, Hawkins packaged a number of distinct contempts into a generic crime of 'contempt of the sovereign' ${ }^{485}$ even though no court (nor Coke) ${ }^{486}$ had suggested that every misprision (or contempt) in respect of the sovereign was a crime. As a result, many legal texts (and Halsbury) came to believe there was a crime called 'contempt of the sovereign'. In respect of Hawkins' categorisation of public nuisance, Spencer stated:

unlike most of his predecessors...Hawkins tried to arrange the multitude of crimes according to a lofty theoretical scheme, with main headings, sub-headings, sub-sub-headings, and so on. As might be expected, Hawkins had problems fitting everything into his tidy scheme, and ended up with an annoying pile of bits of pieces left over. These he seems to have dealt with by taking the vague heading 'common nuisance', using it as a residual category, and stuffing into it things that he could fit in nowhere else. Having done so, he fashioned a definition of the concept broad enough to cover everything he had grouped within it. ${ }^{487}$

One would agree. However, one would go further. Hawkins created the crime of 'public nuisance' just as he created the crime of 'contempt of the sovereign'. I do not believe that either crime existed at common law. Instead, at common law (and much more so under legislation) there existed a number of distinct crimes which were punished on the basis of the rationale expounded by Coke in respect of disorderly houses. They caused annoyance to the public (as opposed to private individuals), ${ }^{488}$ the annoyance being of sufficient severity that it would likely lead to a breach of the peace. As to Hawkins:

\footnotetext{
${ }^{478}$ Ibid, p 5 'If any encroach upon the king's high-way, by hedging, ditching, or otherwise inclose any part of the high-way; this is a nusance, and by you, enquirable, presentable and punishable. If any make any laystalls, dunghills, or lay any timber-wood, or other thing in the highway, whereby the same is in the least obstructing; this is also a nusance and enquirable etc. If any do not scour their ditches, or lop their trees, and keep their bushes low next the king's high-way; this is an occasion of impairing the high way and by you enquirable etc. If any divert an ancient way, or an ancient watercourse out of its proper channel; this is also enquirable etc. If any person lay any carrion, or any other stinking dirt in the high-way, by this means the air is corrupted, which is a nusance, and by you enquirable etc. If any lay any hemp, or otherwise corrupt any common stream of water; this is also a nuisance, and by you enquirable etc. If any do not maintain a sufficient lodge or fence against any common, or common high way, whereby his neighbour's cattle may the more easily trespass on his ground, and he impounds them, this occasions suits and controversies. and tends to the breach of the peace, and consequently by you enquirable etc.' See also Jacob, n 333 (writing in 1715), pp 34-5.

${ }^{479}$ Ibid, p 6 'You are to enquire of eve[s]droppers [sic], such as listen under walls or windows to hear tales, and report them amongst the neighbourhood,; this tends to the breach of the peace...'

${ }^{480}$ Ibid 'You are to enquire and present all common barretors, scolds, and other breakers of the peace, and punish the offenders accordingly.'

${ }^{481}$ Ibid 'You are to enquire of all gaming-houses, houses of bawdry, and other such lewd and disorderly places'.

${ }^{482}$ Ibid 'You are to enquire of all bakers, butchers, poulterers and others, that they vend good and wholesome meat and drink, fit for man's body; if any offend herein, you are to present and punish offenders.'

${ }^{483}$ For texts on the court leet in this period see, in particular, Hearnshaw, n 134 and Jacob, n 333 (1715).

${ }^{484}$ Hawkins, n 10. See also Hale PC, n 44 p 134 in which Hale noted that nuisance, in the criminal sphere, was an inferior offence. Hale did not deal with nuisance in his History of the Pleas of the Crown, see $\mathrm{n} 44$.

${ }^{485}$ See n 474, pp 98-109.

${ }^{486}$ See Coke, n 43, vol 4, p 139 (misprisions divers and several). Coke cited various specific contempts (misprisions) but did not suggest that all contempts were punishable criminally. Nor that there was a general crime of contempt of the sovereign.

${ }^{487}$ Spencer, n 3, p 65. He continued 'Under this heading he put all the odds and ends which Rolle had collected under 'nusans' in his abridgment, where he had used the term as a dumping ground for various exercises by the King's Bench in the creation of new offences, like keeping treasure trove and digging up the wall of a church. He added running a bawdy-house, being a common scold, running a play-house which causes congestion in the street with parked carriages, and running noisome trades in towns. He added two long sections on common nuisance in relation to highways and bridges, in which he includes within the scope of the offence the damage to a highway or bridge, abuse of it, and non--repair by those who owe a duty to repair. Then he had a long section on common nuisance in relation to alehouses, covering not only running a disorderly alehouse but the proprietor of a common inn who refuses to serve a traveller.'

${ }^{488}$ See n 385.
} 


\section{(a) Definition of Common Nuisance}

In respect of crimes below the degree of capital which were against the subject and which did not amount to an actual disturbance of the peace - ones committed by a private person but which affected the public - Hawkins included public nuisance ${ }^{489}$ which he defined as:

an offence against the public, either by doing a thing which tends to the annoyance of all the king's subjects, or by neglecting to do a thing which the common good requires. ${ }^{490}$

In support of his definition, Hawkins cited Rolle's Abridgment (see 15(e)). However, Rolle did not provide a definition. In respect of this definition, Spencer stated:

This definition is so wide that it can be scarcely be called a definition at all, and it is amazing that anyone should assume that Hawkins was describing a single offence, rather than making a residual category of offences which did not fit anywhere else in his scheme. Nevertheless, Hawkins's words have been so interpreted, and his 'definition' is the basis of the definition for the single offence of public nuisance which appears in almost every book on tort or criminal law today. ${ }^{491}$

One would agree. However, this is no different to the very wide statements that one can find in Blackstone, for example. Or the inclusion of public indecency into common nuisance by Russell in his text in 1819 (see 20(a)). Or the very wide definitions (very much so) of the Victorian judge and jurist, Stephen (see 22). In those days , legal writers were much more creative in terms of designing comprehensive schemes into which the scattered remnants of the criminal law might be placed (or forced). However, there is no evidence that any judge prior to Hawkins had ever defined public nuisance in such wide terms or - indeed - had ever said there was such a common law crime.

\section{(b) Categories of Public Nuisance}

In his composite category of public nuisance, Hawkins included a common scold. ${ }^{492} \mathrm{He}$ also included: (i) a common bawdy house; (ii) a common stage for tightrope dancers; (iii) a common gaming house; (iv) a common playhouse. Thus, he stated:

There is no doubt but that common bawdy houses are indictable as common nusances...also it has been said, that all common stages for rope dancers, and also all common gaming houses, are nusances in the eye of the law, not only because of the great temptations to idleness, but also because they are apt to draw together great numbers of disorderly persons, which cannot but be very convenient to the neighbourhood.

Also, it has been holden, that a common playhouse may be a nusance if it draw together such numbers of coaches or people etc as prove generally inconvenient to the places adjacent, and it seems to be a proper distinction between the play houses and the nusances mentioned in the foregoing section, that play houses having been originally instituted with a laudable design of recommending virtue to the imitation of the people, and exposing vice and folly, are not nusances in their own nature, but only become such by accident, whereas the others cannot but be nusances. ${ }^{493}$ (wording divided for ease of reference)

Hawkins also noted that a brewhouse (brewery) erected in an inconvenient place 'wherein the business cannot be carried on without greatly incommoding the neighbourhood' may be a public nuisance, as might as that of a chandler (candlemaker). ${ }^{494}$ So too, to divert part of a public navigable river, thereby weakening the current. ${ }^{495}$

\footnotetext{
${ }^{489}$ Hawkins, n 10, ch 75, p 197. Under this head Hawkins also considered: (a) monopolies; (b) forestalling, ingrosssing and regrating; (c) barratry.

${ }^{490}$ Hawkins continued 'But annoyances to the interests of particular persons are not punishable by a private prosecution as common nusances, but are left to be redressed by the private actions of the parties aggrieved by them. ' Hawkins cited Rolle, $\mathrm{n} 35$, vol 2 , 83 . The definition of Hawkins was cited in Rimmington [2006] 1 AC 459 at p 468 per Lord Bingham.

${ }^{491}$ Spencer, n 3, p 66.

${ }^{492}$ Hawkins, n 10, vol 1, ch 75, p 198. See also n 340.

493 Ibid.

${ }^{494}$ Ibid, p 199.

${ }^{495}$ Ibid. 'It seems certain, that it is a common nusance to divert a part of a public navigable river, whereby the current of it is weakened, and made unable to carry vessels of the same burthen, as it could before.' He cited Noy 103, see W Noy, The Principal Grounds and Maxims (1641, rep Law Book Exchange).
} 
Also, to divide a house in a town for poor people to inhabit in, making it more susceptible to plague. ${ }^{496}$ Finally, Hawkins went on to consider in particular, nusances relating to:

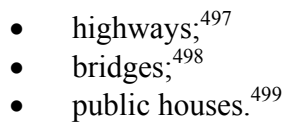

In the above cases, Hawkins referred to legislation governing the same, long since repealed.

\section{(c) Criticism of the Categorisation of Hawkins}

Hawkins may be criticised for his categorisation in that he failed to note that many of the crimes he included in public nuisance were distinct crimes and that it was not necessary to prove they were a 'nuisance ' for the crime to occur.

- To an extent, confusion arose from Coke, who asserted that disorderly houses were suppressed 'being as it were a common nuisance. ${ }^{500}$ However, Coke was referring to the rationale for suppressing brothels, as opposed to asserting two separate crimes were committed at common law, viz: (a) managing a bawdy house; (b) committing a public nuisance;

- For his part, Hawkins treated managing a bawdy house as an example of (b). He then added reference to common stages for rope dancers, gaming houses and playhouses as other examples. To a certain extent this was not unreasonable since these were, invariably, where prostitutes plied their trade as well as in common taverns. ${ }^{501}$

Similarly, Hawkins referred to it being a public nuisance if a common innkeeper: (a) refused to provide board and lodging to a traveller; or (b) harboured thieves or persons of scandalous reputation. ${ }^{502}$ However, the first was a separate crime. ${ }^{503}$ And the second was a crime in the City (and, later to be a crime under the 1839 and 1847 Acts). ${ }^{504}$

\section{(d) Court Leet}

As for the prosecution of crimes of public nuisance, by the time of Hawkins, while the sheriff's tourn still existed (it was abolished in 1887) the court leet was effectively redundant - although, possibly, a few still sat from time to time. Hawkins stated:

it seems to be a general rule, that all common nusances are indictable in this court, as are all annoyances to common bridges or highways, bawdy houses etc and also all other such like offences, as selling corrupt victuals or exposing them to sale, breaking the assise of beer and ale, neglecting to hold a fair or market in pursuance of a grant or prescription. Also, it seems, that the keeping of false weights or measures is indictable in this court, whether it appear that they were actually made use of or not: Also, it is said that all common disturbers of the peace may be here indicted as barretors, common scolds, eves-droppers, and also all common oppressors, as usurers etc and also all dangerous and suspicious persons as vagabonds; or those who go abroad in the night, and sleep in the day, [i.e. nightwalkers] or those who inordinately haunt taverns, having no visible means to live by etc. And also all suitors to the court who shall make default etc. And also all those who shall levy a hue and cry without cause, or shall neglect to levy one where they ought, or to pursue one rightly levied. ${ }^{505}$ (italics supplied)

\footnotetext{
${ }^{496}$ Ibid 'it has been holden to be a common nusance to divide a house in a town for poor people to inhabit in, by reason whereof it will be more dangerous in the time of infection of the plague.' See also $n 435$.

${ }^{497}$ Ibid, pp 200-20. Hawkins considered various pieces of legislation which have been long repealed.

${ }^{498}$ Ibid, pp 220-5. For older indictments re nuisance caused by the non-repair of a bridge or enclosing part of the highway, see W West, Symboleography (1641), vol 2, pp 119-20.

${ }^{499}$ Ibid, pp 225-30.

${ }^{500}$ See n 385.

${ }^{501}$ Once the permitted Southwark brothels were suppressed in 1549 (and, again, in 1655) prostitutes, it seems, gravitated to common taverns (which had private rooms) as well as to playhouses (theatres) and gaming establishments. See McBain, n 90, p 25.

${ }^{502}$ Hawkins, $\mathrm{n} \mathrm{10}$, vol 1, p 225. As to the latter 'it seems to be agreed, that the keeper of an inn may by the common law be indicted and fined, as being guilty of a common nusance if he usually harbour thieves, or persons of scandalous reputation, or suffer frequent disorders in his house, or set up a new inn in a place, where there is no manner of need of one, to the hindrance of other ancient and well governed inns, or keep it in a place in respect of its situation, wholly unfit for such a purpose.'

${ }^{503}$ For City Ordinances against harbouring persons of bad fame see, ns 286 (bad character) \& 307 (ill repute, bad conduct).

${ }^{504}$ See 21.

${ }^{505}$ Ibid, pp 199-200 'it seems to be certain, that any one may pull down or otherwise destroy a common nusance, as a new gate, or even a new house erected in a highway etc for if one whose estate is, or may be, prejudiced by a private nusance actually erected, as a house
} 
Hawkins failed to indicate that many of these were distinct common law crimes (bawdy houses, barratry, common scolds) ${ }^{506}$ or distinct statutory crimes (selling corrupt victuals, Assizes of Bread, Ale and Measures, eavesdroppers, nightwalkers - for which, as well, no 'nuisance' had to be proved). Also, that:

- levying hue and cry was part of frankpledge and breaches of hue and cry were statutory. ${ }^{507}$ There was no requirement that 'nuisance' be proved;

- failing to hold a market (or fair) was not a crime as such; ${ }^{508}$

- usury was not punished as a public nuisance per se; ${ }^{509}$ and

- to be a 'common oppressor' was not a crime. ${ }^{510}$

\section{(e) Conclusion}

Hawkins packaged together many nuisances under a generic crime of 'common nuisance'. However, he failed to note that many were statutory nuisances or distinct common law crimes. It may be noted generally that Hawkins seems to have been unfamiliar with Anglo-Saxon and early English law - as well as with City regulations. Certainly, his citations in his work tend to be later authors, such as Coke and Dalton. However, Hawkins' work was influential. Thus, Burn, Justice of the Peace - another influential work first issued in 1755 and which was to continue until $1869^{511}$ - closely followed Hawkins in respect of public nuisance. ${ }^{512}$ So, perhaps, unfortunately, did Blackstone.

\section{BLACKSTONE (1765-9)}

Blackstone, Commentaries on the Laws of England (1765-9) ${ }^{513}$ discussed both private and public nuisance. He stated:

A third species of real injuries to a man's lands and tenements, is by nusance. Nusance, nocumentum, or annoyance, signifies any thing that worketh hurt, inconvenience or damage. And nusances are of two kinds; public or common nusances, which affect the public, and are an annoyance to all the king's subjects; for which reason we must refer them to the class of public wrongs, or crimes and misdemeanours: and private nusances; which...may be defined, [as] any thing done to the hurt or annoyance of the lands, tenements, or hereditaments of another. ${ }^{514}$

\section{(a) Private Nuisances}

Blackstone categorised these into:

\footnotetext{
hanging over his ground etc may justify the pulling down and destroying such a nusance, whether it was erected before or since he came to the estate, surely it cannot but follow, a fortiori, that one may lawfully destroy a common nusance....' Hawkins also stated 'It has been adjudged, that if a river be stopped, to the nusance of the country, and none appear bound by prescription to clear it, those who have the piscary, and the neighbouring towns, who have a common passage and easement therein, may be compelled to do it.'

${ }^{506}$ Vagabonds were covered under City Ordinances, see 11 \& 12. Also, under general legislation such as 39 Eliz c.4 (1597). See also Powell (in 1668), n 134, pp 93-4.

${ }^{507}$ See e.g. n 263 (Proclamation of 1195). See also Statute of Westminster 1275 (3 Edw 1) c. 9 and McBain, n 70, p 174.

${ }^{508}$ Failure to hold it for a long period could enable the Crown to terminate the franchise, by forfeiture. See GS McBain, Abolishing some more Obsolete Crown Prerogatives. Part 2 (2011) Liverpool LR 32 at p 288. The regulation of fairs was later dealt with the Metropolitan Police Act 1839, ss 38 \& 39 (opening hours, suppression of unlawful fairs). See also Fairs Act 1871.

${ }^{509}$ Hawkins, likely, took his reference to 'usurers' from Sheppard, see n 418. And, while the wardmotes and leets had jurisdiction over the same (see, e.g. 12(a)), articles of the Wardmote of the time of Edward II (1307-27)), this did not mean usury was suppressed as a public nuisance. Further, as Hearnshaw, n 134, p 115, points out usury was obsolete, in effect, by this time with the level of interest regulated by statute (21 Jac c 17). The regulation of usury had long been statutory, see Powell (in 1668), n 134, pp 101-4.

${ }^{510}$ Hannon (1703) 6 Mod 311 (87 ER 1050) 'By the court, First, 'communis deceptor' [common cheat] is too general, and so is 'communis oppresor', 'communis perturbator' etc and so of all other (except barretor and common scold) without adding of particular instances.'

${ }^{511}$ See $\mathrm{n} 11$

${ }^{512}$ Ibid, vol 2, pp 155-7.

${ }^{513}$ Blackstone, n 47. See also H Finch, Law or a Discourse thereof (1759), p 188 'Nusance is annoyance done to one's hereditament. As levying a fair or market to the nusance of another fair or market, building a house so near mine, that the rain that falls from that house falls upon mine etc. All manner of nusances are to be removed, and common nusances, as a wall etc built upon the highway, trees growing upon the river bank, whereby a watercourse is stopped, any man may pull down.' Finch cited A Fitzherbert, New Natura Brevium (see 1st ed, 1652) 184a-b (writs of assize of nuisance).

${ }^{514} \mathrm{Ibid}$, vol 3, p 216. Cited in Rimmington [2006] 1 AC 459 at p 468 per Lord Bingham.
} 
- Corporeal Hereditaments. Blackstone divided them into 3 nuisances which affected a man's dwelling: ${ }^{515}$ (a) Overhanging. If a person built a house so close that the roof overhung another house and threw water on it; (b) Ancient Lights. If ancient lights were stopped. ${ }^{516}$ Noisome Smells. If a person kept their hogs or other noisome animals so near another's house that the stench made the air 'unwholesome'. So, too, with trade related smells. ${ }^{517}$ Similarly, there was nuisance to land if crops were killed by vapour and smoke ${ }^{518}$ or if water was diverted or poisoned; ${ }^{519}$

- Incorporeal Hereditaments. It was a nuisance to obstruct a right of way. ${ }^{520}$ Or to set up a market (or fair) close to another, to its prejudice. ${ }^{521}$

Blackstone noted that the law gave no private remedy for any thing but a private wrong.

Therefore no action lies for a public or common nusance, but an indictment only: because the damage being common to all the king's subjects, no one can assign his particular proportion of it; or, if he could, it would be extremely hard, if every subject in the kingdom were allowed to harrass the offender with separate actions. For this reason, no person, natural or corporate, can have an action for a public nusance, or punish it; but only the king in his public capacity of supreme governor, and pater-familias of the kingdom. ${ }^{522}$ Yet this rule admits of one exception; where a private person suffers some extraordinary damage, beyond the rest of the king's subjects, by a public nusance: in which case he shall have private satisfaction by action. ${ }^{523}$

\section{(b) $\underline{\text { Public Nuisances }}$}

Blackstone defined a public nuisance as follows:

\footnotetext{
${ }^{515}$ Ibid, $\mathrm{p} 217$ 'So that the nusances which affect a man's $d$ welling may be reduced to these three: 1 . Overhanging it, which is also a species of trespass, for cuius est solum eius est usque ad coelum. 2. Stopping ancient lights: and 3. Corrupting the air with noisome smells: for light and air are two indispensible requisites to every dwelling. But depriving one of a mere matter of pleasure, as of a fine prospect, by building a wall, or the like; this, as it abridges nothing really convenient or necessary, is no injury to the sufferer, and is therefore not an actionable nusance.'

${ }^{516} \mathrm{Ibid}, \mathrm{p} 216$ 'If a man builds a house so close to mine that his roof overhangs my roof, and throws the water off his roof upon mine, this is a nusance, for which an action will lie. Likewise to erect a house or other building so near mine, that it stops up my ancient lights and windows, is a nusance of a similar nature.' Blackstone cited Aldred's Case (1610) 9 Co Rep 57b (77 ER 816) (action on the case for erecting a hogsty so near the house of the plaintiff that the air was corrupted. The same applied to a lime kiln or a dye house). See also Fifoot, n 150 , pp 95, 99-101.

517 'A like injury is, if one's neighbour sets up and exercises an offensive trade; as a tanner's, a tallow chandler's, or the like: for though these are lawful and necessary trades, yet they should be exercised in remote places; for the rule is, sic utere tuo, ut alienum non laedas.' [so use your own so as not to injure another's property]. Blackstone referred to Morley v Pragnel (1638) Cro Car 510 (79 ER 1039)(a tallow furnace erected in the neighbourhood of another house is a nuisance). See also Ibbetson, n 210, p 106.

${ }^{518}$ Ibid, pp 217-8 'As to nusances to one's lands: if one erects a smelting house for lead so near the house of another, that the vapour and smoke kills his corn and grass, and damages his cattle therein, this is held to be a nuisance. And by consequence it follows, that if one does any other act, in itself lawful, which yet being done in that place necessarily tends to the damage of another's property, it is a nusance: for it is incumbent on him to find some other place to do that act, where it will be less offensive. So also, if my neighbour ought to scour a ditch, and does not, whereby my land is overflowed, this is an actionable nuisance.'

${ }^{519} \mathrm{Ibid}, \mathrm{p} 218$ 'it is a nusance to stop or divert water that used to run to another's meadow or mill; to corrupt or poison a water course, by erecting a dye-house or a lime pit for the use of trade, in the upper part of the stream; or in short to do any act therein, that in its consequences must necessarily tend to the prejudice of one's neighbour. So closely does the law of England enforce that excellent rule of gospel-morality, of 'doing to others, as we would they should do unto themselves.'

${ }^{520} \mathrm{Ibid}$, 'If I have a way, annexed to my estate, across another's land, and he obstructs me in the use of it, either by totally stopping it, or putting logs across it, or ploughing over it, it is a nusance: for in the first case I cannot enjoy my right at all, and in the latter I cannot enjoy it so commodiously as I ought.'

${ }^{521}$ The same applied to a ferry. Cf. 'But, where the reason ceases, the law also ceases with it: therefore it is no nusance to erect a mill so near mine, as to draw away the custom, unless the miller also intercepts the water. Neither is it a nusance to set up any trade, or a school, in neighbourhood or rivalship with another: for by such emulation the public are like to be gainers; and, if the new mill or school occasion a damage to the old one, it is damnum absque injuria.' [loss without injury]

${ }^{522}$ Blackstone cited Thomas v Sorrell (1673), see n 419.

${ }^{523}$ Blackstone, n 47, vol 3, pp 219-20. Blackstone continued ' As if, by means of a ditch dug across a public way, which is a common nusance, a man or his horse suffer any injury by falling therein; there, for this particular damage, which is not common to others, the party shall have his action. Also if a man has abated, or removed, a nusance which has offended him...he is entitled to no action. For he had a choice of two remedies; either without suit, by abating it himself, by his own mere act and authority; or by suit, in which he may both recover damages, and remove it by the aid of the law: but having made his election of one remedy, he is totally precluded from the other.' Blackstone noted that civil remedies for nuisance were by: (a) action on the case for damages; (b) assize of nuisance; (c) writ quod permittat prosternere. However, Blackstone noted that (b) and (c) were 'now out of use' and they had 'given way to the action on the case', which provided for a remedy by way of damages.
} 
Common Nusances are a species of offences against the public order and economical regimen of the state; being either the doing of a thing to the annoyance of all the king's subjects, or the neglecting to do a thing which the common good requires... ${ }^{54}$ common nusances are such inconvenient or troublesome offences, as annoy the whole community in general, and not merely some particular person; and therefore are indictable only, and not actionable; as it would be unreasonable to multiply suits, by giving every man a separate right of action, for what damnifies him in common only with the rest of his fellow subjects. ${ }^{525}$

He then referred to various examples (in respect of which I have inserted headings):

1. [Highways] Annoyances in highways, bridges, and public rivers, by rendering the same inconvenient or dangerous to pass: either positively, by actual obstructions; or negatively, by want of reparations. For both of these, the persons so obstructing, or such individuals as are bound to repair and cleanse them, or (in default of these last) the parish at large, may be indicted, distreined to repair and amend them, and in some cases fined. Where there is a house erected, or an inclosure made, upon any part of the king's demesnes, or of an highway, or common street, or public water, or such like public things, it is properly called a purpresture.

2. [Offensive Trades/Hogs] All those kinds of nusances (such as offensive trades and manufactures) which when injurious to a private man are actionable, are, when detrimental to the public, punishable by private prosecution, and subject to fine according to the quantity of the misdemeanor: and particularly the keeping of hogs in any city or market town is indictable as a public nusance. ${ }^{526}$

3. [Disorderly Houses] All disorderly inns or ale houses, bawdy-houses, gaming-houses, stage-plays unlicensed, booths and stages for rope dancers, montebanks and the like are public nusances, and may upon indictment be suppressed or fined. ${ }^{527}$

Blackstone then cited 3 statutory nuisances (long repealed). ${ }^{528} \mathrm{He}$ also referred to eavesdroppers ${ }^{529}$ and to common scolds (which he, it seems mistakenly, thought only applied to women). ${ }^{530}$ In his description of public nuisance, Blackstone closely followed Hawkins without checking the early law. Thus, he did not note, for example, that obstructing the highways, keeping hogs and eavesdropping had a statutory basis. Nor that gaming

\footnotetext{
${ }^{524}$ Ibid, vol 4, p 167. See also vol 3, pp 5-6 'whatsoever unlawfully annoys or does damage to another is a nusance; and such nusance may be abated, that is, taken away or removed, by the party aggrieved thereby, so as he commits no riot in the doing of it. If a house or wall is erected so near to mine that it stops my ancient lights, which is a private nusance, I may enter my neighbour's land, and peaceably pull it down. Or if a new gate be erected across the public highway, which is a common nusance, any of the king's subjects passing that way may cut it down, and destroy it. And the reason why the law allows this private and summary method of doing one's self justice, is because injuries of this kind, which obstruct or annoy such things are of daily convenience and use, require an immediately remedy; and cannot wait for the slow progress of the ordinary forms of justice.'

${ }^{525}$ Ibid. This definition was cited in Rimmington [2006] 1 AC 459 at p 469 per Lord Bingham.

${ }^{526}$ Blackstone cited Wigg (1705) 2 Salk 460 (91 ER 397). See also Minish (1776) which concerned a factory for hartshorn, in which case Mansfield CJ is said to the told the jury 'To define what lawful trade is a nuisance I am not able to do...There are places where trades of every kind ought to be carried on and others where trades most necessary to society ought not.' See J Oldham, The Mansfield Manuscripts (Univ of North Carolina Press, 1992), vol 1, p 184. See also Ibid, vol 2, pp 886-93.

${ }^{527}$ Ibid, p 168. He continued 'Inns, in particular, being intended for the lodging and receipt of travellers, may be indicted, suppressed, and the inn-keepers fined, if they refuse to entertain a traveller without a very sufficient cause: for thus to frustrate the end of their institution is held to be disorderly behaviour.'. For this see McBain, n 474. OED, n 4 (mountebank) ' 1. An itinerant quack who from an elevated platform appealed to his audience by means of stories, tricks, juggling and the like, in which he was often assisted by a professional clown or fool.'

${ }^{528}$ Ibid, '4. By statute 10 \& 11 W III c 17 [1698, rep 1934] all lotteries are declared to be public nusances, and all grants, patents, or licences for the same to be contrary to law. 5. Cottages are held to be common nusances, if erected singly on the waste, being harbours for thieves and other idle and dissolute persons. Therefore it is enacted by statute 31 Eliz c 7 [1588, rep 1775] that no person shall erect a cottage, unless he lays to it four acres of freehold land of inheritance to be occupied therewith...6. The making and selling of fireworks and squibs, or throwing them about in any street, is, on account of the danger that may ensue to any thatched or timber buildings, declared to be a common nusance by statute 9 \& 10 W III c 7 [1697, rep 1860] and therefore is punishable by fine.'

${ }^{529}$ Ibid, '7. Eaves-droppers, or such as listen under walls or windows, or the eaves of a house, to hearken after discourse, and thereupon to frame slanderous and mischievous tales, are a common nusance and presentable at the court leet: or are indictable at the sessions, and punishable by fine and finding sureties for the good behaviour.'

${ }^{530}$ Ibid, '8. Lastly, a common scold, communis rixatrix (for our law-latin confines it to the feminine gender) is a public nusance to her neighbourhood. For which offence she may be indicted; and, if convicted, shall be sentenced to be placed in a certain engine of correction called the trebuchet, castigatory, or cucking stool, which in the Saxon language signifies the scolding stool; though now it is frequently corrupted into ducking stool, because the residue of the judgment is, that, when she is so placed therein, she shall be plunged in the water for her punishment.' Cf. Greenwood (in 1730), n 134, p 293 'common barretors...they are of both sexes, scolds, brawlers, inventers and dispersers of calumnies and reports, whereby discord and inquietude arises in the county.' Coke, n 43, vol 3, p 219 (trebuchet) 'Or castigatory, named in the statute of $51 \mathrm{H} 3$ [Assize of the Pillory c. 1266] signifies a cucking stool, and trebuchet properly is a pitfall or downfall, and in law signifies a stool, that falls down into a pit of water, for the punishment of the party in it. And cuck, or guck in the Saxon tongue, signifies to scold or brawl...'
} 
and playhouses were regulated by legislation ${ }^{531}$ and that a keeping a bawdy house was a separate common law crime as was being a common scold (an aspect of barratry).

\section{(c) $\underline{\text { Conclusion }}$}

Blackstone, following Hawkins, created a composite offence of 'public nuisance' by grouping together various disparate crimes. Further, Blackstone's definition of a common nuisance was a textbook - not a judicial - one. It was also eclectic and duplicatory, since he included in the common law crime of public nuisance various statutory crimes as well as other distinct common law crimes. The result was that a person who kept a bawdy house (in the eyes of Hawkins and Blackstone) could now be prosecuted twice over: (a) for the common law crime of keeping a bawdy house; and (b) for a public nuisance.

\section{EAST (1803) \& RITSON (1809)}

(a) East

East, in the sole edition of his text on Pleas of the Crown, ${ }^{532}$ said little about public nuisance, besides noting that, in respect of highways:

All nusances to such are indictable at common law. ${ }^{533}$

He stated no authority for such a wide proposition. East also referred to the Highway Act $1773 .{ }^{534}$ As for bridges, East stated:

The malicious destruction or damaging of public bridges is no doubt punishable as a misdemeanour at common law, being a nuisance to all the king's subjects. ${ }^{535}$

Again, he stated no authority for such a wide proposition. East also referred to the Highway Act $1773{ }^{536}$

\section{(b) Ritson}

Although Ritson did not consider nuisance as such, his text, The Jurisdiction of the Court Leet (1809), contained some useful observations.

- Ritson believed that the court leet existed in Anglo-Saxon times as a franchise from the sovereign. ${ }^{537}$ He also cited Lord Mansfield that the leet derived from the tourn and that the leet and view (review) of frankpledge were the same;

- Usefully, Ritson listed out the jurisdiction of the leet. ${ }^{538}$ Apart from inquiry of major crimes and the Assizes (of bread, ale, weights and measures etc), he referred to nightwalkers (which he treated as governed by the Statute of Frankpledge), ${ }^{539}$ the sale of corrupt victuals (which he treated as governed by the Assize of the Pillory c. 1266), ${ }^{540}$

\footnotetext{
${ }^{531}$ See McBain, n 90, p 33(Disorderly Houses Act 1751)(playhouse), p 34 (Act of 33 Hen VIII c. 9 (1541), s 8, gaming house)).

${ }^{532}$ East, $\mathrm{n} 48$.

${ }^{533}$ Ibid, vol 2, p 1080.

${ }^{534} 13$ Geo 3 c 78 s 42 (rep 1959). East stated 'by the general highway act...the damaging of posts, blocks, and great stones set up to secure causeways, and of the banks which secure and defend the same, and the stones, bricks, or wood, fixed on the parapets or battlements of bridges, as also the pulling down, destroying or defacing of mile stones or direction posts, is made liable on conviction before a [JP] to a penalty not exceeding $£ 5$, nor less than 10 s [shillings]... '

${ }^{535}$ East, n 48, vol 2, p 1080.

${ }^{536}$ East stated 'the [Act] subjects to a penalty of $£ 5$ on summary conviction before a justice of the peace, and in default of payment to whipping, imprisonment, and hard labour, every person who shall 'break, damage, or throw down the stones, bricks, or wood fixed upon the parapets or battlements of bridges.'

${ }^{537}$ Ritson, n 120, p vii 'In [Anglo-Saxon] times, whoever possessed a vill or territory, with the liberties of soc, sac etc was the lord of a manor, had a court leet, court baron and, in a word, every privilege which it seems to have been possible for the monarch to bestow, or for a subject to acquire.'

${ }^{538}$ Ibid, ch 6.

${ }^{539}$ Ibid, p 28. He also thought that the same legislation governed those who haunted taverns ('Of those that continually haunt taverns, and a man knows not whereon they live') and the suspected burglar ('Of those that sleep [in] the day, and watch [in] the night, and eat well and drink well, and have nothing.').

${ }^{540}$ Ibid, p 32.
} 
the punishment of common scolds ${ }^{541}$ and purprestures on the king or lords. ${ }^{542}$ None of these he treated as public nuisances.

However, under that head he stated:

Of highways stopped or straightened...Of ways and paths unjustly obstructed or straightened...Of royal ways not [sufficiently] enlarged...Of ways and paths stopped or diverted...Of walls, houses, gates, ditches, or marle-pits [or other disturbances], raised or made near the public [upon any common] way, to the nuisance of the same way, and to the danger of passengers and of those who have raised and made the same...Of ditches, walls, causeways, pools, or such like, raised, prostrated, or exalted to nuisance...Of walls, houses, ditches, and hedges, set up, or beaten down, to nuisance...Of purprestures made in common places, in land, or in water, or elsewhere. Of purprestures made in lands, woods, and waters, to nuisance... Of the course of water diverted. Of waters stopped, straightened, or turned aside...Of waters turned aside or obstructed...Of waters turned or led out of their right course...Of those who remove or corrupt landmarks.... Of landmarks taken away or injuriously changed...Of landmarks broken, removed, or diminished... Of boundaries removed to common nuisance...Of bounds withdrawn and taken away...Of bridges and of causeways broken, and who ought to repair them...Of ditch not scoured, or bridge broken....Of all common nuisances.

Most of these citations were to Britton, Fleta, Mirror as well as to the Statute of Wales 1284 and the Statute of Frankpledge c. 1325 with a couple to caselaw. ${ }^{543}$ What may be noted is that Ritson used 'common nuisances' as a generic description of specific nuisances which affected the public over which the leet had jurisdiction. ${ }^{544} \mathrm{He}$ was not suggesting that 'common nuisance' per se was a crime. Further, Ritson noted that presentments to the leet had to be 'ad commune nocumentum', otherwise it was a private nuisance and, thus, not subject to the criminal law (unless a special case). ${ }^{545}$

\section{RUSSELL (1824), CHITTY (1826)}

\section{(a) Russell}

The last edition of Hawkins (see 17) was in 1824 and the work was (effectively) superceded by Russell, $A$ Treatise on Crimes and Misdemeanors, the first edition of which was in 1819, the last in $1964 .{ }^{546}$ Following Hawkins (and Blackstone), Russell stated:

Nuisance, nocumentum, or annoyance, signifies any thing that worketh hurt, inconvenience, or damage. And nuisances are of two kinds: public or common nuisances, which affect the public, and are an annoyance to all the king's subjects; and private nuisances, which may be defined as any thing done to the hurt or annoyance of the lands, tenements, or hereditaments of another ${ }^{547}$...

Public nuisances may be considered as offences against the public order and economical regimen of the state, being either the doing of a thing to the annoyance of all the king's subjects, or the neglecting to do a thing which the common good requires. But the annoyance or neglect must be of a real and substantial nature: and the fears of mankind, though they may be reasonable, will not create a nuisance. ${ }^{548}$

Russell then considered public nuisances: (a) in general; (b) to public highways; (c) to public rivers; (d) to public bridges. In the case of (a), this was something of a jumble in which Russell covered:

\footnotetext{
${ }^{541}$ Ibid, p 37 'Scolding, often repeated to the disturbance of the neighbourhood, makes it a nuisance, and, as such, it always has been punishable in the leet.' Ritson cited Foxby, see n 341.

${ }^{542}$ Ibid, p 34 'Of every purpresture, and encroachment, made upon the king or the lord...Of every purpresture, and encroachment, made upon the king or upon his dignity...Of those who claim franchises and rights royal...Of new franchises, or customs, or rights, raised since the last view, in water or in land. Of new customs, raised in water or in land.' Ritson cited Fleta, Britton and the Mirror. Also, Ibid, p 35 'Of the way obstructed, or restricted or straightened'. Ritson cited Britton.

${ }^{543}$ Ibid, p 36. That of 'ditch not scoured, or bridge broken' and that 'of all common nuisances' was to 22 Edw 422 , see n 367.

${ }^{544}$ Ibid, p 37 'Nuisance is not to those who have interest in action, but it is to a great number of people, as stopping a way, or not repairing a bridge, and such like'. Ritson cited 27 Edw 3 Lib Ass pl 6 fo 133b-134a, Seipp no 1353.131ass (presentment for enclosing a common) and Brooke, n 33, Leete, 30.

545 Ibid, pp 60-1.

${ }^{546}$ See $\mathrm{n} 3$.

${ }^{547}$ Russell cited Blackstone. He continued 'public or common nusances, as they annoy the whole community in general, and not merely some particular person, are properly punished by indictment, and not the subject of action: for it would be unreasonable to multiply suits by giving every man a separate right of action for what damnifies him in common only with the rest of his fellow-subjects.'

${ }^{548}$ Russell, n 3, vol 1, p 428 . He cited Anon (1752), see App C.
} 
1. Offensive Trades and Manufactures. Among these, Russell referred to: (i) a brewhouse; (ii) a glasshouse (where glass was manufactured);(iii) a swineyard; (iv) a candle manufactory; ${ }^{549}$ (v) a gunpowder mill or keeping a gunpowder magazine near a town; ${ }^{.50}$

2. Disorderly inns or alehouses, bawdy houses (brothels), gaming houses, unlicensed or improperly conducted booths and stages for rope dancers, mountebanks and the like; ${ }^{551}$

3. Open Lewdness and Indecent Exposure. Russell stated that all 'open lewdness grossly scandalous' was punishable as a misdemeanour. ${ }^{552}$ He cited Hawkins, Blackstone and East. ${ }^{553}$ Also, Crunden (1809). ${ }^{54}$ However, these authors had not included indecent exposure as a public nuisance, in their categorisations;

4. Displaying a monstrous person for money; ${ }^{555}$

5. Eavesdroppers and common scolds; ${ }^{556}$

6. Making noises in the night; ${ }^{557}$

7. Spreading infection; ${ }^{558}$

8. Dangerous dogs. ${ }^{559}$

This collection of Russell was even more eclectic than that of Hawkins and Blackstone, since he included indecency, displaying a monstrous person, making noises in the night, spreading infection and dangerous dogs. However, public nuisance had not included indecency before. And displaying a dead monstrous person could hardly be defined as 'annoying' the general public. It was more of failing to provide a Christian burial and, thus, unlawful treatment of the dead, a distinct misdemeanour at common law. Russell also considered nuisances to (a) public highways; ${ }^{560}$ (b) public rivers; ${ }^{561}$ and (c) public bridges. ${ }^{562}$

In conclusion, Russell's definition of public nuisance was as eclectic as that of Hawkins and of Blackstone. He 'added' in, (i) open lewdness and indecent exposure; (ii) displaying a monstrous (dead) person for money; (iii) making noises in the night; (iv) dangerous dogs.

\section{(b) Chitty (1826)}

Chitty, A Practical Treatise on the Criminal Law, was first published in 1826 and it became a standard text of indictments. ${ }^{563}$ It is useful to compare with Russell since the standard form indictments for some of the offences

\footnotetext{
${ }^{549}$ Ibid, p 428.

${ }^{550}$ Ibid, pp 430-1. Russell also cited 12 Geo III c. 61 (1772, rep 1860).

${ }^{551}$ Ibid, pp 431-8.

${ }^{552}$ Ibid, p 438 'In general all open lewdness grossly scandalous is punishable by indictment at the common law: and it appears to be an established principle that whatever openly outrages decency, and is injurious to public morals, is a misdemeanour.'

${ }^{553}$ See Hawkins (17), Blackstone (18) and East (19).

${ }^{554}$ See App D. Russell also cited Sedley (1663), see App D.

${ }^{555} \mathrm{Ibid}, \mathrm{p} 438$ 'to shew a being of unnatural and monstrous shape for money is a misdemeanour.' Russell cited Herring $v$ Walrond (1682), see App C.

${ }^{556}$ In the case of the latter, Russell cited Cooper (1745) 2 Str 1246 (93 ER 1160).

${ }^{557}$ Russell, n 3, vol 1, p 439 'A defendant was convicted on an indictment for making great noises in the night with a speaking trumpet, to the disturbance of the neighbourhood: which the court held to be a nuisance.' Russell cited Smith (1725), see App C.

${ }^{558}$ Ibid. 'The exposing in public places persons infected with contagious disorders, so that the infection may be communicated, is a nuisance.' See also pp 157-9.

${ }^{559} \mathrm{Ibid}$ 'It is said that a mastiff, going in the street unmuzzled, from the ferocity of its nature being dangerous and cause of terror to his majesty's subjects, seems to be a common nuisance; and that, consequently, the owner may be indicted for suffering him to go at large.' Russell cited Burn (see n 11) and Chitty (indictment)(see n 570 for a later reference). See also Tremaine, n 355, p 240 citing Pick (1684)(setting a mastiff on a man, biting him on the leg). However, in that case, public nuisance was not pleaded.

${ }^{560} \mathrm{Ibid}$, pp 448-90.

${ }^{561}$ Ibid, pp

${ }^{562}$ Ibid, pp 490-3.

${ }^{563} \mathrm{~J}$ Chitty, A Practical Treatise on the Criminal Law (1826). See also the first edition of JF Archbold, A Summary of the Law relative to Pleading and Evidence in Criminal Cases (1822) which contained indictments for: (a) carrying on an offensive trade; (b) keeping a common bawdy house; (c) keeping a common gaming house; (d) obstructing a common highway; (e) obstructing the navigation of a public river; (f) not repairing a highway or bridge. Cited in Rimmington [2006] 1 AC 459 at p 469 per Lord Bingham 'He went on to deal with such common nuisances as keeping a disorderly and a common gaming house, although these became statutory offences the same year (3 Geo 4, c 114).'
} 
which Russell embraced within his composite offence of public nuisance, did not refer to 'common nuisance' as such. Thus:

- Disorderly House. Under the heading 'Offences against Decency and Morality', Chitty provided standard indictments for: (a) keeping a bawdy-house or other disorderly house, ${ }^{564}$ and (b) keeping a disorderly house; ${ }^{565}$

- Indecency. Under the same heading as above, Chitty provided standard indictments for: (a) bathing naked near public ways and habitations, ${ }^{566}$ (b) indecently exposing private parts to public view; ${ }^{567}$

- $\quad$ Spreading Infection. Under the heading 'Offences against Public Health etc', Chitty provided an indictment for exposing a child infected with smallpox in a public street; ${ }^{568}$

- $\quad$ Animals. Under the heading 'Nuisances near to Highways, Houses etc', Chitty provided indictments for, inter alia: (a) keeping an unruly bull in a field, through which there was a public footway; ${ }^{569}$ (b) keeping a ferocious dog unmuzzled near a highway; ${ }^{570}$ (c) placing carrion near a highway; (d) keeping dogs which made noises in the night; (e) keeping hogs near a public street; 571

- $\quad$ Offensive Trades \& Manufactures. Under the same heading as above, Chitty provided indictments: (a) against a butcher, for using his shop as a slaughterhouse in a public market; (b) erecting a furnace with a boiler and using it for boiling tripe and the offal of beasts; (c) laying dung in a public market, whereby the air was infected and the passengers annoyed; (d) erecting and continuing a soap manufactory near a highway; (e) keeping a coppersmith's shop so as to annoy the neighbourhood; (f) carrying on the trade of a brazier [i.e. one who worked with brass] so near several dwellings as to be a nuisance; $(\mathrm{g})$ cutting down and destroying a turnpike gate, $;^{572}$

- $\quad$ Unlicensed Alehouses, Gaming Houses etc. Under the heading 'Indictments for keeping Unlicensed Alehouses, Gaming Houses etc', Chitty provided indictments for: (a) keeping an alehouse without a licence; (b) keeping an unlicensed dancing house; (c) keeping a house for cock fighting; (e) keeping a common gaming house; ${ }^{573}$

\footnotetext{
${ }^{564}$ Chitty, n 563, vol 2, pp 38-9 'That CD...a certain common bawdy house...unlawfully and wickedly did keep and maintain; and in the said house, for filthy lucre and gain, divers evil disposed persons, as well men as women, and whores, on the days and times aforesaid...there unlawfully did receive and entertain...to the great damage and common nuisance of all the liege subjects of our the said lord the king, in manifest destruction, ruination, and subvertion of youth, and other people, in their manners, conversation, estate, and obedience, and against the peace etc...' (italics supplied)

${ }^{565}$ Ibid, p 40a 'That AH... did keep and maintain, and yet doth keep and maintain, a certain common, ill governed, and disorderly house, and in the said house, for his own lucre and gain, certain persons, as well men as women, of evil name and fame...there unlawfully and wilfully did cause and procure...there to be and remain etc...to the great damage and common nuisance of all the liege subjects of our lord the king, there inhabiting, residing, and passing, to the evil example, etc and also against the peace etc.' (italics supplied)

${ }^{566} \mathrm{Ibid}$, ' That $[\mathrm{X}]$....being a person of a wicked, depraved, and abandoned mind and disposition, and wholly lost to a due sense of decency and morality, and intending as much as in him to corrupt the morals of his majesty's liege subjects ...unlawfully, wickedly, deliberately, and wilfully, did expose and exhibit himself naked and in an indecent posture and situation near to, and in front of divers houses of the liege subjects of our said lord the king, situate at etc and, also near to a certain public, and common king's highway, there and also in the presence of divers liege subjects or our said lord the king, both male and female, with intent to vitiate and corrupt the morals of his majesty's liege subjects, to the great scandal and subversion of decency; religion and good order, to the great corruption of the morals and manners of his majesty's liege subjects, to the evil example, etc and against the peace etc.'

${ }^{567}$ Ibid, p 41 'That [X] being a person of most wicked, lewd, lascivious, depraved, and abandoned mind and disposition, and wholly lost to all sense of decency, morality, and religion, and intending as much as in him lay, to vitiate and corrupt the morals of his majesty's liege subjects, and to stir up and excite in their minds filthy, lewd, and unchaste desires and inclinations...unlawfully, wickedly, deliberately and wilfully, did expose and exhibit his private parts, in a most indecent posture, situation, and practice, to divers of the liege subjects, both male and female, of our said lord the king, with intent to vitiate and corrupt the morals of his majesty's liege subjects, and to stir up and excite in their minds, filthy, lewd, and unchaste desires and inclinations, to the great scandal and subversion of religion and good order, to the great corruption of the morals and manners of his majesty's liege subjects, to the evil example of etc and against the peace etc.'

${ }^{568}$ Ibid, p 553 That $[\mathrm{X}]$ did carry [Y, infected with smallpox along the said] open and public way and passage, dwelling houses, habitations, residences, and common highway...to the great damage and common nuisance of all the said ...liege subjects of our said lord the king, to the evil example of all other persons, and against the peace of our said lord the king, his crown and dignity.' (italics supplied)

${ }^{569}$ Ibid, vol 3, pp 641-2 'That [X] unlawfully did keep at large, and still doth keep at large, a certain bull, of a very fierce, furious, and unruly nature [in a field where there was a footway and the bull gored $\mathrm{Y}$ ] a liege subject of our said lord the king, then passing in and along the said footway, in the said field, about his lawful affairs and business....insomuch that her life was greatly despaired of [and the bull is still in the field]... to the great terror and common nuisance of all the liege subjects of our lord the king, passing and repassing, in and along the said footway.' (italics supplied)

${ }^{570}$ Ibid, p 643 'That [X] near unto the king's common highway there, unlawfully did keep and still doth keep, a certain large dog, of a very fierce and furious nature [unmuzzled] to the great damage, terror, and common nuisance of all the liege subjects of our said lord the king, in, by, and through the said highway there, going, returning, passing, repassing, and labouring etc.'(italics supplied)

${ }^{571}$ Ibid, p 647 ('to the great damage and common nuisance')(italics supplied).

${ }^{572}$ Ibid, pp 641-65.

${ }^{573}$ Ibid, pp 671-7.
} 
- $\quad$ Bridges. Under the heading 'Offices against Public Police and Economy', Chitty provided, inter alia, indictments: (a) against the county for suffering a bridge to decay; (b) not maintaining and widening a public bridge and keeping battlements of a sufficient height; (c) not repairing a bridge; (d) suffering a bridge to be out of repair and unsafe; (e) leaving a parapet wall prostrate, so that passage was dangerous, ${ }^{574}$

- $\quad$ Watercourses. Under the heading 'Offices against Public Police and Economy', Chitty provided, inter alia, indictments: (a) against a city corporation for not cleansing a watercourse; (b) suffering a port to be filled with rocks, stones etc as to prevent ships entering; (c) failing to repair part of a sewer wall. Also, obstructions such as; (d) making embankments and narrowing the Thames; (e) stopping watercourses; (f) erecting bridges and dams and obstructing or injuring navigation; (g) diverting watercourses; (h) nuisance and obstruction caused by keeping a vessel sunk there, ${ }^{575}$

- Highways. Under the heading 'Offices against Public Police and Economy', Chitty provided, inter alia, indictments: (a) for erecting (and keeping shut) a gate across a highway; (b) locking a gate erected in a common road; (c) obstructing a footway, by pulling down a style and erecting a bridge, wall etc across a way; (d) digging a ditch and raising a hedge across a highway; (e) putting chains and posts across a footway; (f) erecting and continuing a building on a common footway; $(\mathrm{g})$ obstructing a highway in various forms; $(\mathrm{h})$ continuing a building on a highway; (i) building a wall; (j) digging up a road and placing on it building materials; (k) taking up a pavement (and erecting a portico) and narrowing a footpath; (l) building on a highway and narrowing it; $(\mathrm{m})$ building a shed (or porch) projecting onto a highway; (n) continuing a gate on a highway; (o) stopping up a footway; (p) making holes in a footway; (q) digging a hole in a public street; (r) digging a horse pond and erecting a cistern in a common passage; (s) laying soil in a street; ( $\mathrm{t}$ ) shooting (i.e. throwing) dirt in a highway; (u) laying rubbish in a square or in a carriage way; (v) digging up (or destroying) the pavement of a public highway; (w) laying timber in a highway; (x) placing carts in a public street; (y) baiting a bull in market place; (z) letting off fireworks in a public street; (aa) causing offensive smells; (bb) driving cattle etc. ${ }^{576}$

In respect of these indictments the following may be noted:

- Disorderly House. The indictment made it clear that, while the same was a common nuisance, keeping a disorderly house was, per se, a crime. Thus, 'nuisance' did not have to be proved;

- $\quad$ Indecency. The indictments did not allege that this was a common nuisance. Thus, 'nuisance' did not have to be proved;

- Eavesdropping/Common Scold. Chitty provided no indictments - likely, since these offences were obsolete by the time his text was published.

In the Victorian period there commenced a number of treatises on the law of nuisance. ${ }^{578}$

\section{ACTS OF $1839 \& 1847$}

As noted in $\mathbf{1 1}$ and 12, there were various Ordinances relating to the City which specified various common nuisances, as gathered together in the Liber Albus in 1419. By Victorian times, doubtless, the situation had become almost unintelligible as to what Ordinances still applied. Thus, in 1839 and in $1847{ }^{579}$ were passed two important pieces of legislation which, inter alia, specified various public nuisances, which pieces of legislation are still extant in part. viz.

- Metropolitan Police Act 1839 ('1839 Act'). This applied to the Metropolitan Police District ('MPD') which, today, covers Greater London - excluding the City as well as the Inner and Middle Temples;

\footnotetext{
${ }^{574}$ For the list, see vol 2, pp xxi-ii.

575 Ibid.

${ }^{576}$ Ibid.

${ }^{577}$ Chitty referred to the ducking stool, see Chitty, n 563, vol 1, p 796.

${ }^{578}$ EW Garrett, Law of Nuisances (1st ed, 1890; 3rd ed, 1908), D Gibbons, Law of Dilapidations and Nuisances (1st ed, 1839; 2nd ed, 1849); DD Keane, Nuisances Removal Act (1st ed, 1855; 4th ed, 1870); WG Lumley, Nuisances Removal and Diseases Prevention Act (1st ed, 1849; 3rd 1866); W McKenzie \& P Handford, Model By-Laws, Rules and Regulations under the Public Health and other Acts (1899) and Model By-Laws as to Nuisances, New Streets and Buildings (1904); EH Pearce \& Meston, Law of Nuisances (1926); JT Smith, Nuisance Removal Acts (1st ed, 1855, last ed (4th) 1867); WR Steer, Law of Smoke Nuisance (2nd ed, 1948); GV Yool, An Essay on Waste, Nuisance, and Trespass (1863).

${ }^{579}$ See also Acts in respect of the removal of nuisances in England: 11 \& 12 Vict c. 123 (1848) and 12 \& 13 Vict c. 111 (1849). These Acts were repealed and consolidated in the Nuisances Removal Act for England 1855 (18 \& 19 Vict c. 121) for which see especially, s 26 (unwholesome meat etc), s 27 (carrying on noxious trades). See also GC Oke, The Magisterial Synopsis (Butterworths, 1857 ), pp $328,685$.
} 
- Town Police Clauses Act 1847 ('1847 Act'). It was designed to extend many of the provisions of the 1839 Act to specified towns and districts. It was later extended by the Public Health Act 1875 to all urban districts.

Among various matters which Russell categorised as 'common nuisances' (see 20), these Acts made statutory provision for those in respect of: (a) dangerous dogs; (b) making noises in the night; (c) a taverner permitting drunkenness or other 'disorderly conduct' in his tavern (i.e. prostitutes, or other persons of notoriously bad character, being there). Thus, these were now specific statutory offences - even if they may have been common law nuisances prior to this.

\section{In conclusion, by virtue of the 1839 and 1847 Acts, such common law nuisances as there were shrank greatly.}

\section{STEPHEN (1883)}

Stephen, in his History of the Criminal Law of England (1883), did not deal with nuisance. ${ }^{580}$ However, his proposed legislation which was never enacted, A Digest of the Criminal Law: Crimes and Punishments $(1883),{ }^{581}$ defined a public nuisance as follows:

A common nuisance is an act not warranted by law or an omission to discharge a legal duty, which act or omission obstructs or causes inconvenience or damage to the public in the exercise of rights common to all Her Majesty's subjects. It is immaterial whether the act complained of is convenient to a larger number of the public than it inconveniences, but the fact that the act complained of facilitates the lawful exercise of their rights by part of the public may show that it is not a nuisance to any of the public. ${ }^{582}$

Stephen also set out articles for keeping a disorderly house, ${ }^{583}$ which he defined to comprise a:

- Common bawdy house (brothel); ${ }^{584}$

- Common gaming house; ${ }^{585}$

- Common betting house; ${ }^{586}$

- Disorderly place of entertainment. ${ }^{587}$

Stephen also defined a disorderly inn. ${ }^{588}$ These matters are not considered further since they were (or later became) covered by legislation. Stephen also defined as a public nuisance, the following:

- Nuisances to Health, Life, and Property. 'Every person commits a common nuisance who does anything which endangers the health, life, or property of the public or any part of it. ${ }^{589}$ An example he provided was of carrying a child infected with smallpox along a highway. ${ }^{590}$ Also, maintaining highly explosive substances near to others; ${ }^{591}$

\footnotetext{
${ }^{580}$ Stephen, n 54

${ }^{581}$ Ibid, n 53 .

${ }^{582}$ Stephen, n 53, Digest, art 176 (common nuisance). See also Report by the Criminal Code Bill Commissioners in 1879 (C 2345), draft Code, Section 150 'Common Nuisance Defined. A common nuisance is an unlawful act or omission to discharge a legal duty, which act or omission endangers the lives safety health property or comfort of the public, or by which the public are obstructed in the exercise or enjoyment of any right common to all Her Majesty's subjects. Section 151. What Common Nuisances are Offences. Every one shall be guilty of an indictable offence, and shall be liable upon conviction thereof to one year's imprisonment, who commits any common nuisance which endangers the lives safety or health of the public, or which injures the person of any individual. Section 152. When a Common Nuisance is not to be Deemed Criminal. Any one convicted upon any indictment or information for any common nuisance other than those mentioned in the preceding section shall not be deemed to have committed a criminal offence; but all such proceedings or judgments may be taken and had as heretofore to abate or remedy the mischief done by such nuisance to the public right.' See also citation of these in Rimmington [2006] $1 \mathrm{AC} 459$ at pp 469-70 per Lord Bingham.

${ }^{583} \mathrm{Ibid}$, art 179 'The following are disorderly houses, that is to say, common bawdy houses, common gaming houses, common betting houses, disorderly places of entertainment.'

${ }^{584} \mathrm{Ibid}$, art 180. 'A common bawdy house is a house or room, or set of rooms, in any house kept for purposes of prostitution. And it is immaterial whether indecent or disorderly conduct is or is not perceptible from the outside'.

${ }^{585} \mathrm{Ibid}$, art 181.

${ }^{586} \mathrm{Ibid}$, art 182.

${ }^{587} \mathrm{Ibid}$, art 184.

${ }^{588} \mathrm{Ibid}$, art 185 'A disorderly inn is an inn kept in a disorderly manner and suffered to be resorted to by persons of bad character for any improper purpose. Every person who keeps a disorderly inn, or who, being an innkeeper, refuses, without reasonable grounds, to entertain any person ready and willing to pay for entertainment therein, commits a misdemeanour.'

${ }^{589} \mathrm{Ibid}$, art 187. It continued ' Publicly and wilfully exposing or causing to be exposed for sale articles of food unfit for consumption, and knowingly permitting servants to mix unwholesome ingredients in articles of food, are acts endangering the health or life of the public
} 
- Offensive Trades. 'Every one commits a common nuisance who, for the purposes of trade or otherwise, makes loud noises, or offensive or unwholesome smells in such places and under such circumstances as to annoy any considerable number of persons in the exercise of rights common to all her Majesty's subjects.'; ${ }^{592}$

- Nuisances to Highways. 'Every one commits a common nuisance who obstructs any highway, by any permanent work or erection thereon or injury thereto, which renders the highway less commodious to the public than it would otherwise be; or who prevents them from having access to any part of it by an excessive and unreasonable temporary use thereof, or by so dealing with the land in the immediate neighbourhood of the highway as to prevent the public from using and enjoying it securely.'; 593

- Nuisances to Bridges. 'Every one is guilty of a common nuisance who, being bound by law to repair a bridge, leaves it unrepaired.'; ${ }^{594}$

- Nuisances to Navigable Rivers. 'Every one is guilty of a common nuisance who willfully diverts or obstructs the course of a navigable river so as appreciably to diminish its convenience for purposes of navigation, even though the alteration may, upon the whole, be for the convenience of the public; but the owner of a vessel wrecked in a navigable river is not guilty of a common nuisance because he does not remove it. ${ }^{595}$

It may be noted that Stephen's definitions were very wide and much of his own creation. In respect of the prevention of the burial of dead bodies and dis-interring, he treated this as a separate crime. ${ }^{596}$

\section{GARRETT (1890)}

In 1890, a useful text (now long forgotten) was published, Garrett, The Law of Nuisances. ${ }^{597}$ It sought to gather together relevant common law and statutory material on the law of nuisance. ${ }^{598}$ In so doing, it indicated the very considerable extent to which Victorian legislation had superceded the common law offence of common nuisance and that - even in 1890 - there was little of the former left. As to this, the following may be noted:

- Disorderly Houses. Garrett categorised these as including: (a) bawdy houses; (b) common gaming houses; (c) betting houses; (d) lotteries; (e) unlicensed places of entertainment;

- $\quad$ Public Indecency. Garrett noted that it was a public nuisance to commit an act of gross indecency. ${ }^{599}$ In particular, he referred to: (a) a disgusting and offensive exhibition on a highway or in any place to which the public had access - even though it might be innocent or laudable; ${ }^{600}$ (b) the exposure of obscene matter; ${ }^{601}$ (c) bathing on the sea shore near inhabited houses from which persons might be distinctly seen; ${ }^{602}$

- $\quad$ Highway. As well as noting legislation on the removal of rubbish ${ }^{603}$ Garrett referred to (with reference to the 1847 Act, see 21): (a) 1847 Act, s 28 (throwing rubbish in a street), see App B; ${ }^{604}$ (b) Inclosure Amendment Act 1857, s

within the meaning of this article. Everything is deemed to endanger health, life, or property, which either causes actual danger thereto, or which must do so in the absence of a degree of prudence and care the continual exercise which cannot be reasonably expected.'

${ }^{590}$ See Vantandillo (1815), see App C.

${ }^{591}$ Stephen, n 53, p 127.

592 Art 188.

${ }^{593}$ Art 189.

${ }^{594}$ Art 190.

595 Ibid, art 191.

${ }^{596}$ Ibid, art 175.

${ }^{597}$ Garrett, n 578. See also GB Kennett (ed), The Justices' Manual (26th ed 1891), pp 643-4 (nuisances).

${ }^{598}$ Ibid, Preface, 'The aim of this book is collect and arrange for the first time in one volume the common and statute law as to nuisances.'

${ }^{599}$ Ibid, p 242.

${ }^{600}$ Garrett referred to Grey (1864) and to Clark (1883), see App D. Garrett also referred to the Vagrancy Act 1824, s 4 (a beggar exposing wounds). Ibid, p 245.

${ }^{601}$ Garrett, n 578, p 244 'The exposing for public sale or on public view of any obscene matter calculated to produce a pernicious effect in depraving and debauching the minds of those who read or see it, is a nuisance punishable at common law as a misdemeanor...'. Garrett also noted: (a) 20 \& 21 Vict c 83 (1857, rep) which conferred certain powers of search, seizure and destruction of obscene books; (b) 1847 Act, s 28 (indecent exposure and sale or exhibition of obscene matter, see App B); (c) Vagrancy Act 1824, s 4 (exposing obscene prints). Ibid, p 245 .

${ }^{602}$ Ibid, pp 303-4. Garrett referred to Crunden (1809)(naked bathing), see App D. He also noted that the 1847 Act, s 69 (rep) gave power to urban districts to make byelaws with regard to bathing, see App B.

${ }^{603}$ Ibid, ch 9.

${ }^{604}$ Ibid, p 246. 
12 (laying rubbish on village greens); ${ }^{605}$ (c) 1847 Act, s 28 (laying materials un-inclosed on a highway), see App B; (d) Highway Act 1835, s 68 (interfering with ditches); ${ }^{606}$ (e) TPCA 1847, s 28 (minor obstructions to footways), see App B; (f) Metropolis Management and Building Act 1882, s 6 (posts, rails etc obstructing the highway); (g) General Paving Act 1817, s 72 (projection of house beyond building line) $;^{607}$ (h) temporary obstructions arising from building or other operations or sewer or road repairs. ${ }^{608}$ (i) fencing of dangerous openings near a highway; ${ }^{609}$ (j) breaking up streets for repairs and for gas and water $e t c ;{ }^{610}(\mathrm{k})$ steam engines on highways; ${ }^{611}$

- $\quad \underline{\text { Animals. }}$ Garrett referred to the: (a) Highway Act 1864, s 25 (cattle straying); (b) 1847 Act, s 28 (slaughtering animals in the street), see App B; (c) Public Health Act 1875, s 47 (keeping swine or pigsty in a dwelling house); (d) 1847 Act, s 28 (keeping pigsty near a street), see App B; (e) Public Health Act 1875, s 91 (keeping animals so as to be a nuisance or injurious to health), ${ }^{612}$ (f) 1847 Act, s 36 (bear baiting, cock fighting etc), see App B. ${ }^{613}$ Garrett also considered the responsibility of a person for an animal that was vicious or strayed. ${ }^{614} \mathrm{He}$ also referred to the Contagious Diseases (Animals) Act 1878 and to orders in Council thereunder; ${ }^{615}$

- $\quad$ Street. Garrett referred to the: (a) 1847 Act, s 28 (exposing goods for hire in the street), see App B; (b) Highways Act 1835, s 72 (minor street obstructions); (c) Town Improvements Clauses Act 1847, s 74 (nuisance from allowing water to fall on the street);

- $\quad$ Excessive Traffic. Garrett referred to various pieces of legislation, including: (a) Highways and Locomotives Act 1878, s 23 (excessive weight or extraordinary traffic); (b) 1847 Act, s 28 (reckless driving of carriages etc), see App B;

- $\quad$ Noxious Trades. Garrett referred to (a) Public Health Act 1875, s 112 (any person establishing an offensive trade within an urban district without consent was liable to a penalty); ${ }^{616}$ (b) provisions as to slaughter houses and alkali works; ${ }^{617}$ (c) nuisances arising from the smoke of manufactories, houses etc; ${ }^{618}$

- $\quad$ Explosives \& Fireworks. Garrett referred to the: (a) Explosives Substances Act 1875 (the manufacture, or storage, of explosives was to be licensed); (b) Ibid, s 30 (it prohibited the sale of explosives in a public place); (c) Ibid, s 80 (prohibition on letting off fireworks in a street); (d) 1847 Act, s 28 (discharging of fireworks), see App B ; $^{619}$

- $\quad$ Dangerous Structures. Garrett referred to: (a) Metropolitan Building Act 1855, ss 69-81 (removal of dangerous structures); (b) Metropolitan Building Act 1882, s 17 (dilapidated structures); ${ }^{620}$

- Infectious Diseases. Garrett referred to the case of exposing a child with smallpox in a public highway. ${ }^{621}$ Also, to: (a) Public Health Act 1875, s 126 (exposure of an infected person in a public place; (b) Ibid, s 127 (failure to have

\footnotetext{
${ }^{605} \mathrm{Ibid}, \mathrm{p} 249$.

${ }^{606}$ Ibid, p 253.

${ }^{607}$ Ibid, p 254-5. See also: (a) Public Health Act 1875, s 156; (b) Public Health (Building in Streets) Act 1888; (c) Town Improvement Clauses Act 1847, s 68; (d) Metropolis Local Management Act 1862. Ibid, pp 255-7. These Acts have now been repealed.

${ }^{608}$ Ibid, pp 257-9. Garrett, cited, in particular, (a) Town Improvement Clauses Act 1847, s 80; (b) General Paving (Metropolis) Act 1817, s 75; (c) Metropolis Management Act 1855, s 121; (d) Towns Improvement Clauses Act 1847, s 79; (e) Metropolis Local Management Act 1862, s 21; (f) Municipal Corporations Act 1835, s 90. All these have now been repealed.

${ }^{609}$ Ibid, pp 259-61. In particular, Garrett referred to the 1847 Act, s 28 (openings to cellars), see App B.

${ }^{610}$ Ibid, pp $261-4$.

${ }^{611}$ Ibid, p 280.

${ }^{612}$ Ibid, pp 268-9. Garrett referred to corresponding provisions in the Metropolitan Police Act 1839 and the Nuisances Removal Act 1855, s 8 (rep).

${ }^{613}$ Ibid, p 304.

${ }^{614} \mathrm{Ibid}, \mathrm{ch} 6$. In particular, Garrett considered cattle, bulls, dogs and horses - including the straying and trespass of the same.

${ }^{615} \mathrm{Ibid}, \mathrm{pp}$ 170-4. In particular, the Order in Council no 3446, clause 91 made it illegal for any person: (a) to expose a diseased or suspected animal, horse, ass, or mule, in a market or fair, or in a sale yard, or other public or private place where animals or horses were commonly exposed for sale; (b) to place a diseased or suspected animal, horse, ass, or mule in a fair or other place, adjacent to or connected with a market or a fair, or where animals or horses were commonly placed before exposure for sale...etc.

${ }^{616}$ Ibid, pp 270-1. The Act referred, in particular, to the trades of: (a) blood boiler; (b) bone boiler; (c) fellmonger; (d) soap boiler; (e) tallow melter; (f) tripe boiler; (g) any other noxious or offensive trade, business, or manufacture. There were corresponding provisions in respect of the Metropolis. Ibid, p 271. See also Public Health Act 1875, s 114 (candle house, melting house, melting place, soap house, slaughter house, places for boiling offal or crushing bones). Ibid, pp 271-2.

${ }^{617}$ Ibid, pp 273-4.

${ }^{618} \mathrm{Ibid}, \mathrm{pp} 275-8$. In particular, Garrett referred to legislation dealing with chimneys emitting smoke, steam vessels, engines of water works, railways and highway locomotives.

${ }^{619}$ See also drawing a crowd of noisy and disorderly people close to a dwelling house by music and fireworks. Walker $v$ Brewster (1867) LR Eq 25 (playing music and letting off fireworks within 100 yards of a house, twice a week for several hours). Also, Inchbald $v$ Barrington (1869) LR 4 Ch App 388 (circus within 115 yards of a house, operating for 8 weeks from $7.30 \mathrm{pm}$ to $9.30 \mathrm{pm}$ ).

${ }^{620}$ Ibid, pp 281-2.
} 
a public conveyance dis-infected); (c) Ibid, ss 84 and 86 (failure of the keeper of a common lodging house to notify about infectious disease);

- Dead Bodies. Garrett noted that it was a common law misdemeanor to dis-inter a body without lawful authority. Also, to burn a body when this was offensive to others 'for example, in such a place or manner as to annoy the public, on roads or other places to which they have a right to go.'; ${ }^{622}$

- $\quad$ Sewerage \& Water. Garrett referred to the duties, and liability, of an authority in respect of sewers and cesspools. Also, to: (a) Metropolis Local Management Act 1855, s 64 (duty of an occupier to remedy any offensive pond, pool, ditch etc); (b) Public Health Act 1875, s 91 and the Nuisances Removal Act 1835, s 8 (foul pools, ditches, gutters, watercourses, privy, urinals, cesspools, drains, ashpits were deemed to be a nuisance); ${ }^{623}$

- Dwellings. Garrett referred to penalties imposed in respect of unhealthy dwellings arising from defective sanitary arrangements or conditions as well as bad drainage, cesspools, stagnant water, unwholesome dwellings, overcrowded dwellings and workshops - together with the relevant legislation; ${ }^{624}$

- $\quad$ Unwholesome \& Adulterated Food. Garrett noted that it was a common law nuisance knowingly to send to market for human food, meat unfit for the same. ${ }^{625}$ Legislation made provision for the destruction of this; ${ }^{626}$

- $\quad$ Noise \& Disorderly Conduct. Garrett referred to the: (a) Factories (Steam Whistles) Act 1872 (penalty for using steam whistle or trumpet for the purpose of summoning or dismissing workmen); (b) Locomotives Act 1865, s 3 (locomotive whistle prohibited); (c) Metropolitan Police Act 1864, s 1 (nuisance by any street musician or street singer) ${ }^{627}$ (d) 1847 Act, s 29 (penalties with regard to drunken and riotous or indecent behaviour), see App B;

- Bathing. Garrett indicated that bathing on the sea shore near inhabited houses from which persons might be distinctly seen, was an indictable offence; ${ }^{628}$

- $\quad$ Prostitutes \& Thieves. Garrett referred to (a) 1847 Act, s 28 (prostitutes importuning passengers), see App B; (b) Ibid, ss 34 and 35 (public refreshment establishments which harboured prostitutes and thieves), see App B. ${ }^{629}$

As well as considering these matters, Garrett analysed, in specific chapters, nuisances with regard to: (a) highways; ${ }^{630}$ (b) bridges; ${ }^{631}$ and (c) water. ${ }^{632}$

In conclusion, Garrett's work shows that - by 1890 - legislation had superceded to a great extent the common law on public nuisances. The foundation was the 1847 Act which many pieces of legislation subsequently built upon.

\section{PUBLIC NUISANCE BY 1890}

By 1890, crimes of public nuisance had become statutory in the vast amount of cases. What was left of the common law crime? The answer is, precious little:

- $\quad$ Building. The obstruction of buildings, as well as other nuisances relating thereto, was no longer a common nuisance from a very early date - 1189 in the case of London. By 1890, building (and restrictions thereon) was governed by statutory regulation;

\footnotetext{
${ }^{621}$ Ibid, p 283. See also Vantandillo (1815), see App C.

${ }^{622}$ Ibid, p 287.

${ }^{623}$ Ibid, pp 291-2.

${ }^{624}$ Ibid, pp 292-8. See also AH Manchester, A Modern Legal History of England and Wales 1750-1950 (1980), pp 322-3, re Victorian legislation on housing.

${ }^{625}$ Ibid, p 298. Garrett referred to Stevenson (1862), see App C.

${ }^{626}$ Garrett referred, in particular, to the Public Health Act 1875, s 116 and corresponding provisions regarding the London metropolis. Also, to the Market and Fairs Clauses Act 1847, s 15 (sale or exposure of unwholesome meat or provisions in any market or fair). See also Food and Drugs Act 1875 (re adulteration of food and drugs). Ibid, p 440 et seq.

${ }^{627}$ Ibid, pp 302-3.

${ }^{628}$ Ibid, pp 303-4. Garrett referred to Crunden (1809)(naked bathing), see App D. He also noted that the 1847 Act, s 69 gave power to urban districts to make byelaws with regard to bathing, see App B.

${ }^{629} \mathrm{Ibid}, \mathrm{p} 304$.

${ }^{630} \mathrm{Ibid}, \mathrm{ch} 2$.

${ }^{631}$ Ibid, ch 3 .

${ }^{632}$ Ibid, ch 4 .
} 
- $\quad$ Highways, Waterways, Bridges. These had been the mainstay of public nuisance in early times. For example obstructing the king's or public highways, bridges or waterways. By 1890 (indeed, long before), highways and their obstruction were dealt with by legislation. So too with waterways and bridges;

- $\quad$ Other Common Nuisances. Those covered by London Ordinances in early times, to the extent not obsolete, were incorporated into the 1839 and 1847 Acts. Others were separate common law offences - such as: (a) managing a bawdy house (a brothel); (b) an innkeeper failing to provide board and lodging to a traveller; (c) the failure to bury or inter a person.

The result of this was to make, in late Victorian times, public nuisance an uncertain offence both in nature and scope. Indeed, what it included had - since Hawkins (in 1716)(see 17) - much depended on the personal view of the legal text-book writer. Thus, Harris in his Principles of the Criminal Law (1877), ${ }^{633}$ stated that public nuisance was:

Another offence of wide and vaguely-defined limits...In its definition its extent is indefinite, but in practice it is confined to certain classes of acts which interfere with the normal state of order or comfort. Common nuisances are such annoyances as are liable to affect all persons who come within the range of their operation. They consist of acts either of commission or of omission, that is, causing something to be done which annoys the community generally, or neglecting to do something which the common good requires. ${ }^{634}$

In his category of common nuisance, Harris placed: (a) nuisances to highways, bridges and public rivers; (b) carrying on offensive, or dangerous, trades or manufactures; (c) nuisances which affected public health; (d) houses which interfered with public order and decency (i.e. disorderly inns or taverns, bawdy houses, gaming houses, betting houses, unlicensed (or improperly conducted) playhouses, booths, stages for dancers and the like); (e) lotteries; (f) indecent conduct; ${ }^{635}$ (g) unwholesome food and the adulteration of food. ${ }^{636}$ Harris noted various pieces of legislation in respect of these. He also referred to miscellaneous nuisances:

A vast number of other acts etc have been declared public nuisances; for example, exposing in a public thoroughfare persons afflicted with infectious disease; allowing mischievous dogs to go abroad unmuzzled...keeping fierce animals in places open to the public; ${ }^{637}$ keeping hogs near a public street; keeping a corpse unburied; making great noises in the street at night; eaves dropping...common scolds; and in general anything which is an appreciable grievance to the public at large. ${ }^{638}$

What Harris failed to note was that almost all of these were now statutory or separate common law crimes (unlawful treatment of the dead) or they were obsolete (eavesdropping, common scolds). Another legal text of that time - Disney and Gundry, The Criminal Law (1895) ${ }^{639}$ - gave its own idiosyncratic definition of common nuisance (as prior text writers had done):

A common or public nuisance is an offence against public convenience and economy, and an annoyance to the Queen's subjects. ${ }^{640}$

Among common nuisances, they referring to exposing an infected child in a public street, ${ }^{641}$ keeping a bawdy house or gaming house, obstruction of highways, lewdness, ${ }^{642}$ selling an obscene print ${ }^{643}$ and the dis-interring

\footnotetext{
${ }^{633}$ Harris, n 52 (I cite the 2nd ed, 1881), p 131. The last edition of this work was in 1973.

${ }^{634}$ Ibid, pp 132-3. Harris continued 'Public nuisances are opposed to private nuisances, which annoy particular individuals only, that is, to which all persons are not liable to be exposed. The distinction is one based on the extent of the operation of the evil, and not one relating to the class of evil; inasmuch as all kinds of nuisances which, when injurious to private persons, are actionable as private nuisances, when detrimental to the public welfare, are punishable on prosecution as public nuisances, It is for the jury to determine whether a sufficiently large number of persons are or may be affected so as to make the nuisance 'common' or 'public".

${ }^{635}$ Ibid, p 131 'Indecent Conduct. To this head may be referred the public and indecent exposure of the person, which may be treated as a common nuisance. Also the exposing for public sale or view any obscene book, print, picture, or other indecent exhibition. Both of these offences are misdemeanors...

${ }^{636}$ However, $\mathrm{p}$ 137, he noted that the law on adulteration of food was chiefly contained in the Sale of Food and Drugs Act 1875.

${ }^{637}$ Cf. Spencer, n 3, p 77 (Dangerous Wild Animals Act 1976).

${ }^{638}$ Harris, n 52, p 136.

${ }^{639}$ HW Disney \& H Gundry, The Criminal Law (1895).

${ }^{640}$ Ibid, p 118.

${ }^{641}$ Vantandillo (1815), see App C. Cf. G Williams, Criminal Law: The General Part (2nd ed, 1961), p 609, n 2 'it is a public nuisance to expose a child suffering from smallpox in a public place, even though no infection results.' See also Burnett (1815) 4 M \& S 272 (105 ER 835) (exposing a child with smallpox in a public street).

${ }^{642}$ Disney, n 639, p 120 'Open and notorious lewdness is an offence against the public convenience and economy. For a man to expose his private parts so that they are visible to more than one person in a public place is an offence punishable with fine and imprisonment.' Disney
} 
dead bodies. ${ }^{644}$ Finally, in 1902 was published Kenny, 'Outlines of Criminal Law.' A student text (based on lectures delivered at Cambridge) it said little on public nuisance, - besides noting that it was a crime for which there was no pardon. ${ }^{645}$

In conclusion, by 1890, what comprised a public nuisance at common law was scant and its definition eclectic and, often, unduly wide. Further, writers in the late Victorian period often failed to note that many examples they gave were statutory crimes - as opposed to the common law crime of public nuisance. Or that many of the common crimes they referred to were distinct offences, not requiring nuisance to the public to be shown.

\section{RUSSELL (1902- 64) ${ }^{646}$}

The principal legal texts in this period were Harris (the last edition was in 1973, see 26), Kenny, Outlines of Criminal Law, the last edition of which was in $19666^{647}$ and Russell, the last edition of which was in 1964. There was also Cross and Jones, Introduction to Criminal Law, the first edition of which was in 1948. However, it did not deal with public nuisance. ${ }^{648}$ The last edition of Russell (edited by Turner in 1964) considered public nuisance under the following chapter headings:

(i) public mischief;

(ii) eavesdroppers, common scolds and nightwalkers (all abolished in 1967);

(iii) nuisances to public health;

(iv) nuisance by trade or business;

(v) offences relating to dead bodies;

(vi) obscenity and indecency; ${ }^{649}$

(vii) offences in connection with premises (inns, bawdy houses, gaming, betting, lotteries).

As with prior legal writers, this categorisation of Russell was eclectic since - for example - other writers had not cited public mischief as a common nuisance. Indeed, it was a separate crime as were those relating to the unlawful treatment of the dead. Further, matters of indecency were not common nuisances and had not been pleaded as such in indictments (see e.g. Chitty in 1826, see 20). As to the others chapters of Russell (as edited by Turner):

\section{(a) Nuisances to Public Health}

Turner referred to two matters:

referred to Webb (1848), see App D. Also, to Wellard (1884) 14 QBD 68 per Huddlestone B 'It seems to be established that, speaking generally, whatever openly outrages decency, and is injurious to public morals, is a misdemeanor at common law....'

${ }^{643}$ Ibid, p 121 'the selling of an obscene print is an offence punishable with fine and imprisonment, with or without hard labour.' Disney referred to the 1847 Act (offence to offer for sale or to exhibit to public view in any street a profane or indecent book, drawing or paper), App B. Also, to the Indecent Advertisements Act 1889 (rep)(offence to put up within view from any highway or to deliver to any person passing or to throw down in any area any picture or printed matter of an indecent nature).

${ }^{644}$ Ibid, p 122 'To dig up a dead body and remove it from a place where it was buried is an offence punishable with fine or imprisonment, or both.'

${ }^{645}$ Kenny, n 55, p 492 'Pardons may be granted by the king for all crimes, except two. For under the Habeas Corpus Act the king cannot pardon the offence of sending a prisoner out of the realm to evade the protection of the writ of habeas corpus; and, even at common law, he cannot pardon a person convicted of a common nuisance until after the nuisance has been abated, for such a pardon might prejudice the rights of the private persons injured by the nuisance.' Ibid, $\mathrm{p} 15$

${ }^{646}$ For an interesting general text on indecency, see DJ Cox et al, Public Indecency in England 1857-1960 (Routledge, 2015).

${ }^{647}$ The last edition said very little on the subject - as had the first edition in 1902 and subsequent editions. It stated, pp 423-4 ' It is a misdemeanour at common law either by act or omission to cause substantial annoyance to the subjects of the Crown in general by exposing to danger or in other ways affecting injuriously their lives, health, property or even morals, or by obstructing them in the exercise of the rights common to all subjects of the realm. The gist of the offence lies in the inconvenience created, and not in the intention or even knowledge of the person held responsible, for example, as owner or even occupier of the land or premises from which the nuisance emanates. Owing to the wide range of offensive conduct covered by the common law under this head, and to the number of statutes which have been enacted in addition in order to repress particular instances of interference with public health, morals and amenities, the law of public nuisance is too extensive a subject for convenient inclusion in a book for students who should therefore turn to larger works on criminal law for further information.'

${ }^{648}$ Cross \& Jones (2nd ed, 1949), n 56, p 58 noted that: 'A master is criminally liable for a public nuisance created on his property or on the highway by his servant, even if the latter was disobeying orders. This is because 'the object of the prosecution is not to punish the defendant, but to prevent the nuisance from being continued."

${ }^{649}$ Turner considered: (a) obscene libel (now abolished); (b) legislation (e.g. Obscene Publications Act 1959, Venereal Disease Act 1917, Children and Young Persons (Harmful Publications) Act 1955); (c) indecent exhibitions: (d) indecent exposure. 
- $\quad$ Contagious Disease. He stated: 'it has been held a public menace to expose in a public place a human being or an animal suffering from a disease communicable to man ${ }^{650}$ However, Turner also noted that preventing the spread of certain infectious human diseases was governed by legislation. ${ }^{651}$ In the case of animals, he referred to the Diseases of Animals Act $1950 ; ;^{652}$

- $\quad$ Unwholesome Food. He stated it was 'an indictable misdemeanour knowingly to sell food unfit for human consumption, or to mix unwholesome ingredients in anything made and supplied for the food of man. ${ }^{653}$ The offence may be classified either as a public nuisance or as a common law cheat. The common law remedy by indictment is not affected by the provision of the Sale of Food and Drugs Acts ${ }^{654}$ or the Public Health Acts. Summary proceedings in respect of most of the nuisances above described are authorised by the statutes mentioned above, but without prejudice to the right to resort to common law remedies...If a person publicly exposes or causes to be exposed for sale in a market meat unfit for human food as and for meat that is fit for human food, knowing it to be not so, he is indictable at common law.' 655

The crime of selling unwholesome food had in fact been covered (at least) thrice over:

(i ) a statutory nuisance pursuant to the Assize of the Pillory c.1266 (repealed in 1863);

(ii) the common law crime of cheat (abolished by the Theft Act 1968, s 32);

(iii) public nuisance (according to various writers) !

One is dubious whether (iii) was appropriate since no 'nuisance' to the public had ever to be shown, to make it a crime. It may be noted that the sale of food was also, later, governed by the Sale of Goods Act 1893 - now the Sale of Goods Act 1979, ss 13 (sale of goods by description) and s 14 (implied terms re quality and fitness).

\section{(b) Nuisance by Trade or Business}

Turner considered nuisance arising in respect of the following:

- $\quad$ Noise \& Vibration. Turner noted that - while a noisy trade could be dealt with as a public nuisance - 'most of the decisions as to nuisance by noise or vibration are in actions for nuisance caused to individuals suffering particularly there from or under by-laws made by local authorities;' 656

- $\quad$ Stench, Smoke etc. Turner noted a public nuisance might be caused by smoke, stench, or effluvia, if they created serious public discomfort or injury to health. Also, that offensive trades and manufactures could be a public nuisance if carried on to destroy the comfort (or endanger the health) of the neighbourhood. ${ }^{657}$ Turner cited examples in respect of: a brewhouse, a glasshouse, a swine yard, a tallow furnace and steeping stinking skins in water - without noting these had been regulated by legislation for some time. ${ }^{658}$ Turner also considered nuisance with reference to gas, electricity and railways; ${ }^{659}$

\footnotetext{
${ }^{650}$ Turner cited Vantandillo (smallpox), see App C. Also, Metropolitan Asylum District Managers v Hill (1881) 6 App Cas 193, 204 (any infectious disease). Also, Henson (1852)(horse suffering from glanders), see App C.

${ }^{651}$ Turner, n 55, vol 2, p 1400 'In addition to the common law obligation with respect to infectious disease, elaborate provisions are made under the Public Health Act, 1936, the Public Health (London) Act, 1936, and the National Service Health Act, 1946, for preventing the spread of certain specified infectious diseases, and for punishing on summary conviction persons who disobey the provisions of the Acts or of regulations made under them. The offences created not being indictable do not fall within the scope of this work.'

${ }^{652}$ Ibid, p 1401 'Under the Diseases of Animals Act, 1950, s 20, the Minister of Agriculture and Fisheries has power to make orders regulating the movement and public exposure of animals (including poultry, s 45) suffering from, or suspected of suffering from diseases, and for the cleansing and disinfection of yards, sheds and other places, or vehicles, used for animals in connection with their transport, sale or display.'

${ }^{653}$ Turner cited Dixon (1814), Mackarty \& Fordenbourgh (1705) 2 Ld Raym 1179 (92 ER 280)(unwholesome wine, a case of cheat) and Shillito $v$ Thompson (1875), see App C.

${ }^{654}$ Turner referred to the Food and Drugs Act 1955, ss 8-12. See also Ibid, p 1403.

${ }^{655}$ Turner cited Stevenson (1862), Jarvis (1862) and Shillito v Thompson (1875), see App C. However, such a sale must be intentional, see Crawley (1862), see App C.

${ }^{656}$ Turner, n 55, p 1404. Turner also noted that 'Claims for nuisance by vibrations have been common since the introduction of electrical and other machinery: but the proceedings have been taken for private nuisance, and unless the vibration is only of a temporary character injunctions have been granted.'

${ }^{657}$ Turner cited Banbury USA v Page (1881) 8 QBD 97 (offence under the Public Health Act 1875, s 47 to keep swine in a dwelling house or so as to be a nuisance to any person. Not necessary that there should be any injury to health). See also Davey (1805) 5 Esp 217 (170 ER 791)(smoke and vapour from coke insufficient nuisance).

${ }^{658}$ See n 616. For pigs, see 1847 Act, see App B.

${ }^{659}$ Ibid, pp 1408-10. This material is now dated.
} 
- $\quad$ Public Danger. Turner gave as examples; (a) dangerous dogs (without noting the 1847 Act, see App B); (b) negligently blasting stone in a quarry; ${ }^{660}$ (c) allowing a house near a highway to become dangerous; ${ }^{661}$ (d) erecting a gunpowder mill or keeping a gunpowder magazine near a town (explosives were dealt with by the Explosives Act 1875$) ;{ }^{662}$ (e) fireworks (without noting the 1847 Act, see App B);

This analysis of Turner was not very helpful since it failed to note pertinent legislation.

\section{(c) Offences in Connection with Premises}

Turner stated:

It is a public nuisance at common law, to keep a house, room, or other place of such a kind, or in such a manner, as to cause disorder or scandal or so as to obstruct the highways by drawing crowds. ${ }^{663}$

In support of this, Turner cited, inter alia, Hawkins, Blackstone and Dalton as well as an elderly case. ${ }^{664}$ However, his statement was too wide (re disorder and scandal per se) and the caselaw does not bear it out. Turner also referred to particular premises:

- Inns, Public Houses \& Refreshment Houses. Turner cited various statutory offences (now repealed). ${ }^{665} \mathrm{He}$ referred to the offence of a person keeping a common inn refusing board or lodging to a traveller (noting there was also a civil offence for the same). ${ }^{666} \mathrm{He}$ also stated that an innkeeper was liable to indictment if 'his house is 'disorderly'. ${ }^{667}$ However, his proposition is too wide (in respect of 'violate law and good order') and not supported by the caselaw; ${ }^{668}$

- $\quad$ Crowds, Regatta, Boxing Club. Turner cited Moore (1832) where a crowd outside a pigeon shooting range was held to be a nuisance. ${ }^{669}$ So too, at a regatta ${ }^{670}$ and outside a boxing club. ${ }^{671}$ Injunctions were granted to persons especially affected;

- Cockfights, Racecourses, Theatres. These were governed by legislation then, and now. Turner failed to mention the 1847 Act, re worrying animals, including cock and bear fighting, see App B; $;^{672}$

- Bawdy Houses. Turner noted that a brothel (common bawdy house) was a form of disorderly house. However, he also noted that it was 'within' the Sexual Offences Act 1956, s 33. The word 'within' was something of a misnomer since the Act was clearly intended to make statutory provision on brothels and, thus, superceded the common law; ${ }^{673}$

- $\quad$ Gaming, Betting, Lotteries. These were governed by legislation then, and now.

\footnotetext{
${ }^{660}$ Turner cited Mutters (1864), see App C.

${ }^{661}$ Turner cited Watts (1703) and Watson (1703), see App C. Dangerous buildings were dealt with in Victorian legislation, see text to n 620. See also Public Health Act 1936.

${ }^{662}$ This was dealt with in Victorian legislation, see Explosives Act 1875. Spencer, n 3, p 76-7 'Keeping explosives in a dangerous place is an offence under the Explosives Act 1875, and dumping poisonous waste is a crime under the Control of Pollution Act 1974.'

${ }^{663}$ Turner, $\mathrm{n} 55$, vol 2, p 1434.

${ }^{664}$ Watson (1703), see App C.

${ }^{665}$ Turner cited: (a) Prevention of Crimes Act 1871, s 10; (b) Metropolitan Police Act 1839, s 44; (c) Refreshment Houses Act 1860, ss 32 \& 41 ; (d) 35 \& 36 Vict c 94, s 75; (e) Licensing Act 1872, ss 13-5. These have been repealed.

${ }^{666}$ Turner, n 55, p 1434.

${ }^{667}$ Ibid, pp 1435, 1441.

${ }^{668}$ Turner also stated 'At common law a disorderly house is not defined, but any house which a jury finds to be open to and frequented by persons who so conduct themselves there as to violate law and good order may be a disorderly house'. Turner cited Berg (1927), see App D and Quinn [1962] 2 QB 245. However, these cases were related to sexual matters and did not bear such a wide interpretation. The first is also dubious in so far as it related to public nuisance. See McBain, $n$ 90, p 40-3.

${ }^{669}$ See App C.

${ }^{670}$ Bostock v North Staffordshire Ry (1852) 5 De G \& Sm 584 (64 ER 1253)(the D held regattas on a reservoir they owned, being a nuisance to $P$. An injunction was granted).

${ }^{671}$ Bellamy $v$ Wells (1890) $60 \mathrm{LJ}$ Ch 156 (the nuisances to other residents in the street comprised the noise from the assembled crowds, whistling for cabs and cabs answering the whistles. An injunction was granted).

${ }^{672}$ Turner, n 55, pp 1436-7. Turner also discussed the Disorderly Houses Act 1751 (rep).

${ }^{673}$ See generally, McBain, n 90, especially p 50, n 295 citing Singleton v Ellison (1895), see App D.
} 


\section{(d) $\underline{\text { Conclusion }}$}

Turner's chapter was useful in that it showed the - almost comprehensive - extent to which legislation had superceded the common law offence of common nuisance. However, Turner's analysis was not up to date in that it failed to mention legislation (such as the Town Police Clauses Act 1847) which covered some of the extant common law offences he mentioned.

\section{SMITH \& HOGAN (1965) \& HARRIS (1973)}

The first edition of Smith and Hogan, Criminal Law, was in $1965 .{ }^{674}$ Following Stephen (see 22) it defined public nuisance as :

an act not warranted by law or an omission to discharge a legal duty, which act or omission obstructs or causes inconvenience or damage to the public in the exercise of rights common to all His Majesty's subjects. ${ }^{675}$

\section{(a) Nature of Public Nuisance}

Smith and Hogan indicated that - although the most important example of public nuisance was the obstruction of the highway - it also included a wide variety of other interferences with the public. They provided the following examples (which I have supplemented by the references of Harris to legislation in the final edition of his work in 1973):

- $\quad$ Air Pollution. Carrying on an offensive trade which impregnates the air 'with noisome and offensive and stinking smoke. ${ }^{1676}$ Also, causing excessive noise and dust during quarrying operations. ${ }^{677}$ The Public Health Act 1936 (supplemented by the Clean Air Acts 1956 and 1968 and the Noise Abatement Act 1960) declared the following to be 'statutory nuisances' - any premises, animals, accumulations, deposits, dust or effluvia, which either are, or are kept in such a manner or place as to be, prejudicial to health or a nuisance, ${ }^{678}$

- $\quad$ River \& Sea Pollution. Polluting a river with gas destroying the fish and rendering the water unfit for drinking. ${ }^{679}$ Also, discharging oil in the sea in circumstances it was likely to be carried onto English shores and beaches. ${ }^{680}$ The Deposit of Poisonous Waste Act 1972 made it a summary offence for a person to deposit waste on land, or to cause or permit waste to be deposited where the waste was a of a kind which was poisonous, noxious or polluting and its presence on the land was liable to give rise to an environmental hazard. The Rivers (Prevention of Pollution) Acts 1951- 61 made it an offence to cause (or knowingly permit) to enter a stream any poisonous, noxious or polluting matter or matter which impeded the flow of water in a manner leading (or likely to lead) to a substantial aggravation of pollution;

- Contagious Disease. Unnecessarily and with full knowledge of the facts, exposing in a public highway a person infected with a contagious disease. ${ }^{681}$ The Public Health Act 1936 (as amended) contained numerous provisions on preventing the spread of infectious diseases. In particular s 148 made it a summary offence for a person, knowing that he (or someone in his care) was suffering from an infectious disease, to expose other persons to the risk of infection by his presence (or the presence of the person in his care) in any public place, shop etc; ${ }^{682}$

\footnotetext{
${ }^{674}$ See $\mathrm{n} 57$.

${ }^{675} \mathrm{Ibid}, \mathrm{p} 561$. They also noted ' A person who has suffered particular damage as a result of a public nuisance can maintain an action for damages in tort; and the major importance of public nuisance today is the civil remedy which it affords.' For another very wide definition of common nuisance see PJ Fitzgerald, Criminal Law and Punishment (1962), pp 72-3 'At common law it is the offence of public nuisance to do an act whose effect is to endanger the life, health, property, morals, or comfort of the public, or to obstruct the public in the exercise or enjoyment of rights common to all the subjects of the realm. ...The common law on public nuisance has been to a large extent supplemented and supplanted by statute.'

${ }^{676}$ White and Ward (1757), see App C.

${ }^{677}$ A G v PYA Quarries Ltd (1957), see App C. See also Harris, n 52 (1973 ed), p 220 who referred to Lister (1856), see App C.

${ }^{678}$ There was a fine for disobedience. See also Harris, n 52 (1973 ed), p 223.

${ }^{679}$ Medley (1834), see App C.

${ }^{680}$ Southport Corp v Esso Petroleum Co Ltd [1954] 2 QB 182 at p 197 per Denning LJ. Harris, n 52 (1973 ed), p 221, noted that the Petroleum (Consolidation) Act 1928 regulated the keeping of petroleum spirit, the breach of which was, as a rule, punishable on summary conviction. Failure to give notice in entering a harbour that a ship was carrying petroleum spirit was punishable on summary conviction (s 8). Harris also referred to Atomic Energy and Radioactive Substances Acts of 1946-60 which regulated the sale and use of radioactive substances and the accumulation and disposal of radioactive waste.

${ }^{681}$ Vantandillo (1815), see App C. See also Harris, n 52 (1973 ed), p 220.

${ }^{682}$ See also Harris, n 52, pp 220-1 who noted that 'Other provisions are designed to prevent: (i) a person in this condition carrying on certain occupations and (ii) the spread of infection via, for example, laundries, libraries, public conveyances and accommodation.' See also Spencer, n 3, p 76 'The Public Health Act 1936 also creates a number of offences concerned with the spread of infectious diseases.'
} 
- $\quad$ Animals. Taking a horse in a public place knowing that it had glanders and that that was an infectious disease; ${ }^{683}$ Also, keeping a fierce and unruly bull in a field crossed by a public footway. ${ }^{684}$ The Diseases of Animals Act 1950 (with regulations thereunder) created a variety of offences designed to prevent the spread of disease among animals; ${ }^{685}$

- $\quad \underline{\text { Food }}$. Sending food to market, knowing it was to be sold for human consumption and that it was unfit for the same; ${ }^{686}$

- $\quad$ Corpse. Burning a dead body in such a place - and such a manner - as to be offensive to members of the public passing along a highway or other public place; ${ }^{687}$

- $\quad$ Explosives etc. Harris noted that the manufacture, keeping, selling and import of gun-powder, nitro-glycerine and other explosive substances was governed by the Explosives Acts 1875 and 1923. They did not affect the common law liability for nuisance. ${ }^{68}$

Smith and Hogan noted that a great many varieties of nuisance were now governed by legislation. ${ }^{689}$ They also noted some pre-requisites of public nuisance:

- Isolated Act or Omission. Public nuisance might be committed by an isolated act or omission, ${ }^{690}$ whereas private nuisance always involved some degree of repetition or continuance; ${ }^{691}$

- $\quad$ Substantial \& Unreasonable. The interference with the public's rights must be substantial and unreasonable. It must be caused by some unnecessary and unreasonable act (or omission) by D. ${ }^{62}$ Thus, not every obstruction of the highway was unreasonable; ${ }^{63}$

- $\quad \underline{P u b l i c}$. The nuisance must be widespread. Smith and Hogan cited Denning LJ: 'a public nuisance is a nuisance which is so widespread in its range or so indiscriminate in its effect that it would not be reasonable to expect one person to take proceedings on his own responsibility to put a stop to it, but that it should be taken on the responsibility of the community at large. ${ }^{694}$ This was a question of fact; ${ }^{695}$

Mens Rea. It was unnecessary to establish it was D's object to create a public nuisance; ${ }^{696}$

Vicarious Liability. In at least some types of public nuisance, a master was liable for the acts of the servant even though he expressly prohibited it. ${ }^{697}$

\footnotetext{
${ }^{683} \mathrm{~S} \& \mathrm{H}, \mathrm{n}$ 57, p 561 referred to Henson (1852), see App C.

${ }^{684}$ Ibid. They cited Archbold. See also Harris, n 52 (1973 ed), p 220 (keeping a ferocious dog unmuzzled).

${ }^{685}$ Harris, n 52 (1973 ed), p 226.

${ }^{686}$ S \& H, n 57, p 561 referred to Stevenson (1862), see App C. See also Shillito v Thompson (1875) and Dixon (1814), See App C. See also Harris, n 52, p 220 who noted this was also summarily punishable under the Food and Drugs Act 1955.' Spencer, n 3, p 76 'Public nuisance prosecutions were at one time brought against tradesmen who sold unwholesome food, or who gave short weight; the first of these is now comprehensively covered by the Food Act 1984, and the second by the Weights and Measures Acts 1985 and the Trades Descriptions Act 1968.'

${ }^{687}$ S \& H, n 57, p 561 referred to Price (1884), see App C.

${ }^{688}$ In particular, Harris, n 52, p 221, noted that the Explosives Act 1875 forbade the sale of gunpowder and explosives (including fireworks) to any child apparently under the age of 13. It also forbade the throwing or lighting of fireworks in any highway, street or public place.

${ }^{689} \mathrm{~S} \& \mathrm{H}, \mathrm{n} 57$, p 562 'A great many varieties of nuisance are now the subject of special legislation and proceedings are unlikely to be brought at common law where there is a statutory remedy. But the common law may still be useful where no statute has intervened or where the penalty provided by statute is too slight.'

${ }^{690} \mathrm{~S} \& \mathrm{H}$ referred to Watts (1703) and to $A G v$ Tod Heatley (1897), see App C. See also Harris, n 52 (1973 ed), p 220 who also cited Barnes $v$ Ward (1850), see App C.

${ }^{691} \mathrm{~S} \& \mathrm{H}$ referred to AG v PYA Quarries Ltd (1957), see App C per Denning LJ. Also, to Mutters (1864) and to Garland (1851), see App C. See also Harris, n 52 (1973 ed), p 220.

${ }^{692}$ S \& H, n 57, 562 cited Dwyer v Mansfield (1946) and Fabbri v Morris (1947), see App C.

${ }^{693}$ Jones (1812) and Cross (1812), see App C. See also Ellis v Smith (1962), see App D.

${ }^{694}$ AG v PYA Quarries Ltd (1957), see App C.

${ }^{695}$ Lloyd (1802), see App C. Cf. PYA Quarries, see App C.

${ }^{696}$ See Moore (1832), see App C. S \& H also referred to Bellamy v Wells (1890) 60 LJ Ch 156 and to Lyons, Sons \& Co v Gulliver [1914] 1 Ch 631 (theatre queue obstructing highway, affecting P's adjoining premises. Held nuisance and injunction would be granted).

${ }^{697}$ S \& H, n 57, p 564. They also cited Stephens (1866) and Medley (1834), see App C. Cf. Chisholm, v Doulton (1889) 22 QBD 736 (charge under the Smoke Nuisance (Metropolis) Act 1853).
} 
Smith and Hogan then considered obstruction of the highway. However, most of this related to legislation which has now been superceded or relates to the law on public meetings. ${ }^{698}$

\section{(b) Conclusion}

The text of Smith and Hogan in 1965 - as well as that of Harris in 1973 - indicated how little was left of the common law offence of public nuisance, since so much had become statutory. It may also be noted that Smith and Hogan did not treat an innkeeper refusing to provide board and lodging as an aspect of public nuisance. ${ }^{699}$ Nor keeping a disorderly house - which it treated as a separate offence. ${ }^{700}$ Nor indecency, such as indecent exposure. $^{701}$

\section{WILLIAMS (1983), LAW COMMISSION (1983) \& SMITH (1987)}

\section{(a) Glanville Williams}

In his Textbook of Criminal Law, a student text the first edition of which was in $1978,{ }^{702}$ Glanville Williams said little on public nuisance, besides noting:

Some common law crimes are so vaguely defined that it is easy to extend them when purporting to apply them. This is particularly true of public nuisance, a heterogeneous group of offences bearing a single name, which gives some signs of taking the place in the judicial armoury formerly occupied by public mischief. ${ }^{703}$

Noting that a public nuisance was a crime as well as, in some cases, a tort - whereas a private nuisance was only a tort except where it was made a specific statutory offence ${ }^{704}$ - Williams also referred to abatement of nuisance. $^{705}$

\section{(b) $\underline{\text { Smith (1987) }}$}

Smith, in his Offences against Public Order (1987), considered public nuisance. ${ }^{706}$ He stated:

Public nuisance is a curious hybrid creature, being both a common law misdemeanour and a tort. ${ }^{707}$

Notwithstanding that the purposes of the proceedings are entirely different in character, being punishment and compensation respectively, the rule is that once the plaintiff in a civil action has proved the crime of public nuisance, he can maintain an action in tort by showing also that he has suffered particular damage. Having regard to the different purposes of the proceedings, it is quite likely that the criminal and the civil courts will come to quite different conclusions as to what is, for example, a reasonable user of the highway. Civil proceedings may be brought by, or on the relation of the Attorney-General, which would appear to be the most appropriate form of proceedings where the nuisance is an on-going one. The law clearly is that a single act may be indictable.

\footnotetext{
${ }^{698}$ Ibid, pp 565-6.

${ }^{699} \mathrm{~S} \& \mathrm{H}$ did not deal with this offence.

${ }^{700}$ Ibid, p 311 'It is a common law misdemeanour to keep a disorderly house and a brothel or bawdy house is one variety of disorderly house.'

${ }^{701}$ Ibid, p 318 'It is a common law misdemeanour to commit an act outraging public decency in public and in such a way that more than one person sees, or is at least able to see, the act. The most common way of committing this offence is by indecently exposing the body.' In particular, they cited Sedley (1663), see App D.

${ }^{702}$ G Williams, Textbook of Criminal Law (2nd ed, 1983).

${ }^{703}$ Ibid, p 16.

${ }^{704}$ Ibid, p 522.

${ }^{705}$ Ibid 'Another form of self-help is abatement of nuisance, as where a member of the public removes an obstruction in the highway. The right extends even to a private nuisance, where there is an obstruction to a private right of way. Presumably there is a right to use moderate force get past a person who is deliberately obstructing a highway or other way. Lord Denning MR put the law even more widely: 'Every person who is prevented from carrying out his lawful pursuits is entitled to self-help, so as to prevent an unlawful obstruction.' This proposition goes beyond the decisions, but it is a useful principle that might well be developed.' The reference was to $R v$ Chief Constable of Devon and Cornwall [1982] QB 458 at 470G. Williams also noted, p 953, n 3 'There were three crimes at common law in which something like vicarious liability is or was recognised: criminal libel, nuisance and contempt of court.'

${ }^{706}$ ATH Smith, The Offences against Public Order (1987). For an earlier text discussing public nuisance on the highway see M Supperstone (ed), Brownlie's Law of Public Order and National Security (2nd ed, 1981), pp 74-7.

${ }^{707}$ In a fn, Smith states 'More accurately, perhaps, a series of misdemeanours grouped together under the generic term nuisance.' Smith referred to activities such as: (a) securing the release of a mental patient (Soul (1980), see App C; (b) making obscene or hoax phone calls (Norbury (1978) and Madden (1975) see App C; (c) obstructing rights of way on the highway; (d) brothel keeping (Thompson-Schwab $v$ Costaki [1956] 1 WLR 335 and Tan [1984] QB 1053). See also Tynan v Balmer [1967] 1 QB 91 (picketing).
} 
The Law Commission did not consider the law of nuisance as part of its review of the common law public order offences, partly because of the diversity of forms that the offence might take. Instead, it expressed the hope that prosecutors would not feel the need to resort to the offence in public order situations. ${ }^{708}$ That sentiment is echoed, but the fact is that the form of public nuisance that consists of the obstruction of the highway has been prosecuted as recently as 1964 , and a prosecutor may be tempted to feel that if a person were to incite a massive obstruction, the penalty provided for by the statutory offence of obstructing the highway is insufficient...Although in theory the offence is punishable with imprisonment for life, in practice the maximum should not exceed two years' imprisonment unless the case is a serious one. ${ }^{709}$

Smith followed the wider definition of Stephen (see 22) as to public nuisance, adding:

The courts have put a number of glosses on this definition, and there is authority for saying that, in the criminal law at least, the obstruction must be actual as opposed to potential, it must be substantial, it must be unreasonable, and a conviction should be quashed if the jury are not given the opportunity to say whether or not the obstruction is unreasonable, a considerable number of persons must be affected so that the obstruction is truly public, and the whole is subject to the application of the de minimis rule. ${ }^{710}$

Smith noted that indictments for public nuisance for organising disruptive public meetings and processions appeared to be rare and of comparatively modern origin. He also adverted to the wide and scanty nature of recent cases such as Clark (No 2)(1964) ${ }^{711}$ and Moule (1964) ${ }^{712}$ and noted:

Although it is difficult to be dogmatic when the decisions are so briefly reported, the courts appear to have had little regard to the other qualifications with which the offence is hedged about, and the view may be taken that, should there be any attempt to revive this form of the offence, its constituent ingredients should be scrutinised with considerable care by the courts. ${ }^{713}$

Smith also noted problems with the mens rea required for the crime. ${ }^{714}$

\section{(c) $\underline{\text { Conclusion }}$}

Smith was of the view that the crime of public nuisance - in the context of obstruction of the public highway at least - was vague, amorphous and offensive to the principle of legality. ${ }^{715}$ This was also the view of others such as Fleming ${ }^{716}$ and Spencer. ${ }^{717}$

\section{SPENCER (1989)}

In 1989, Spencer in an article, Public Nuisance - A Critical Examination, considered the topic. ${ }^{718}$ He noted that:

\footnotetext{
${ }^{708}$ See Law Commission, Working Paper no 82. Offences against Public Order. No 123 (1982), para 1.8

${ }^{709}$ Smith, n 706, pp 206-7.

${ }^{710} \mathrm{Ibid}, \mathrm{p}$ 208. Smith continued 'It is plain that not every obstruction is a nuisance. It must be unlawful. A person is free to block the highway for the purposes of repairing his house (indeed he commits a public nuisance if he allows his house to fall into disrepair so that it becomes a danger to the public), and it must follow that he is entitled to take at least reasonable steps to repair his property, even though these might mean inevitable interference with the rights of the public. Where a person causes a crowd to gather, he may be guilty of an offence if he causes actual inconvenience.'

${ }^{711}$ See App C. Smith stated 'the defendant organised a procession of some 2,000 people, blocking the streets of central London. The report does not disclose either the duration of the obstruction, nor the time of day at which it occurred. The trial judge neglected to tell the jury that, for a conviction for incitement to commit nuisance, it had to be proved that the obstruction was unreasonable.' See also D Williams, Keeping the Peace (1967), pp 215-6.

${ }^{712}$ Ibid. Smith stated 'in Moule it appears to have been established that sitting down on the highway is prima facie an unreasonable obstruction. The decision surely requires the qualifications that the person must sit down with the intention of disrupting and obstructing the traffic, and must in fact disrupt.'

${ }^{713}$ Smith, n 706, p 209.

${ }^{714} \mathrm{Ibid}$ 'Since it is so rarely prosecuted in modern times, it is difficult to be confident about the precise mental element in public nuisance. In the older cases, there is some authority to the effect that it is not necessary to establish that it was the defendant's object to create a nuisance. This is re-inforced by the point that, since the civil action involves establishing that the crime has been committed, something less than intention or advertent recklessness will suffice. In Walker v Horner [[1875] 1 QBD 46] Cockburn CJ expressed the view that wilfulness was required for proceedings on indictment.'

${ }^{715}$ Ibid, p 207, fn 74 .

${ }^{716}$ JG Fleming, The Law of Torts (6th ed, 1983), p 378 who indicated that the concept of nuisance had become 'so amorphous as to defy rational exposition' and a 'catch-all for a multitude of ill-assorted sins.' (quoted by Smith, n 706, p 207, fn 74).

717 (1984) 148 JPN 805 and reply by JN Spencer (1985) 149 JP 678.

${ }^{718}$ Spencer, $\mathrm{n} 3$.
} 
The person who commits a public nuisance incurs liability to life imprisonment and unlimited fines. He can be made vicariously liable for the offence if it is committed by his servants. He can be ordered to stop it by an injunction, and made to pay damages in tort if it causes anyone loss. With such a broad concept in existence, backed with such broad remedies, what need have we of any other criminal offence? - or torts? or remedies in administrative law? Everything in public nuisance runs contrary to modern notions of certainty and precision in criminal law - and indeed, in civil law as well. ${ }^{719}$

After discussing the history of the offence, Spencer stated:

almost all the prosecutions for public nuisance in recent years seem to have taken place in one of two situations: first, where the defendant's behaviour amounted to a statutory offence, typically punishable with a small penalty, and the prosecutor wanted a bigger or extra stick to beat him with, and secondly, where the defendant's behaviour was not obviously criminal at all and the prosecutor could think of nothing else to charge him with. ${ }^{720}$

Spencer gave as examples the cases of: Norbury (1978) ${ }^{721}$ (obscene phone calls); Clark no 2 (1964) $)^{722}$ and Moule (1964) ${ }^{723}$ (obstructing the highway); Soul (1980) ${ }^{724}$ (seeking to spring a mental health patient); Wheeler (1971) ${ }^{725}$ (wild animals kept in a garden); Madden (1975) ${ }^{726}$ (bomb hoax); Holme (1984)(eccentric behaviour) ${ }^{727}$ and Silveire)(unsuccessful prosecution for public nuisance against a person who displayed earrings made from human foetuses) ${ }^{728}$ Spencer concluded by arguing that:

There is surely a strong case for abolishing the crime of public nuisance. The criminal law would be improved by the removal of a vague and infinitely extensible offence, and it would not have any harmful repercussions on the civil law. There is an alternative view, however. If there is no case for retaining a common law offence that consists in effect of doing anything that the courts dislike, there may be a case for a general offence of doing anything which creates a major hazard to the physical safety or health of the public, in order to fill the accidental gaps that inevitably appear in the coverage provided by specific statutory offences. Such an offence, though broad, would have identifiable boundaries to it, and it could hardly catch any behaviour other than that which clearly deserves and needs to be punishable as a criminal offence. Thus, as an alternative to abolition we could keep a general offence of public nuisance, but redefine it by statute so that it is limited to behaviour which creates a threat to public safety or health. This would provide a handle against polluters and environment-destroyers who find new ways of endangering our lives, and would cause less disturbance in civil law than would be caused by abolishing public nuisance altogether. Indeed, if the statutory definition of public nuisance also included obstructing or endangering the highway there would be no disturbance to the civil law at all. ${ }^{729}$

Spencer noted that - if the crime of public nuisance were abolished - so too would be the possibility of obtaining an injunction to stop one. However, he noted that, under the Local Government Act 1972 (s 222) a local authority could apply for an injunction to prevent any crime being committed in their area, if they considered it to be in the interests of the local community to apply for one - and it was not limited to the crime of public

\footnotetext{
${ }^{719}$ Ibid, p 55

${ }^{720}$ Ibid, p 77. Also, p 76 'Over the last hundred years, however, virtually the entire area traditionally the province of public nuisance prosecutions has been comprehensively covered by statute.'

${ }^{721}$ See App C. Spencer, n 3, p 77 by [prosecuting as a public nuisance] 'the prosecutor elevated a summary offence then punishable with a $£ 50$ fine into an indictable offence potentially punishable with an unlimited fine and life imprisonment.'

722 Ibid.

${ }^{723}$ Spencer, n 3, p 77 'Under the Highways Act 1959 obstructing the highway was then a summary offence punishable with a fine of 40s. But they were prosecuted for incitement to commit a public nuisance at common law, and by this means one of them [Clark] received a sentence of eighteen months' imprisonment.'

${ }^{724}$ Ibid. 'the defendant was prosecuted for public nuisance when she tried to 'spring' a man detained for homicide in Broadmoor. This was a statutory offence under section 129 of the Mental Health Act 1959 punishable with a possible two years' imprisonment, and indeed she was initially prosecuted for the statutory offence as well for public nuisance. For some reason the judge quashed the section 129 count, however, and it was the crime of public nuisance of which she was eventually convicted. The Court of Appeal then obligingly held that public nuisance extended to cover what she had done.'

${ }^{725}$ Ibid, 'a man kept a puma and two leopards in his garden, to the understandable terror of his neighbours: behaviour now, but not then, punishable under the Dangerous Wild Animals Act 1976.'

${ }^{726} \mathrm{Ibid}, \mathrm{p} 78$ 'the defendant was prosecuted for public nuisance for perpetrating a bomb-hoax - behaviour that now amounts to a statutory offence punishable with five years' imprisonment.' Spencer referred to the Criminal Law Act 1977, s 51.

${ }^{727} 1984$ CLY No 2471. Spencer, n 3, p 78 'an eccentric who upset his neighbours by a catalogue of bizarre behaviour which included playing one chord on his piano all night, playing a radio at top volume whilst it was suspended out of his bedroom window on a rope, and 'behaving in an intimidating manner on the public highway, imitating an ape."

${ }^{728}$ Independent, 7th Feb, 989. See also Spencer, n 3, p 78.

${ }^{729}$ Spencer, n 3, p 84.
} 
nuisance. ${ }^{730}$ This was additional to public health powers. ${ }^{731}$ As to the private individual, Spencer thought that it was hard to see how he would be worse off ${ }^{732}$ and the outcome in respect of damages would not be different. ${ }^{733}$

\title{
In conclusion, Spencer argued for the abolition of the crime of public nuisance.
}

\section{RIMMINGTON \& GOLDSTEIN (2006)}

This case concerned two appeals raising separate issues. ${ }^{734}$

\section{(a) $\underline{\text { Cases }}$}

In Rimmington, a person engaged in a campaign of sending racially abusive hate mail. The House of Lords held that this did not fall within the offence of public nuisance, which only addressed acts (or omissions) which injured the public collectively (common injury) and not a series of acts against individuals. In Goldstein, G, an ultra-Orthodox Jew, supplied kosher food. Owing a debt to an old friend E, who pressed him for payment, G sent a cheque in the post and included a small quantity of salt - a wry joke in recognition of the age of the debt (salt being used to preserve kosher food). At the postal sorting office, the salt leaked. Thought to be anthrax, a postal worker called the police who evacuated the building which disrupted the postal system. Convicted of public nuisance, this was quashed by the House of Lords, Lord Bingham stating:

\begin{abstract}
...the escape of the salt was not a result which [G] intended. Nor, plainly was it a result which he knew would occur, since it would have rendered his intended joke entirely futile. It would seem farfetched to conclude that he should reasonably have known that the salt would escape, at any rate without detailed consideration of the type of envelope used and the care taken in sealing it. He himself said that he had no idea the salt would leak out...I conclude that it was not proved against $[\mathrm{G}]$ that he knew or reasonably should have known (because the means of knowledge were available to him) that the salt would escape in the sorting office or in the course of post. ${ }^{735}$
\end{abstract}

Thus, a pre-requisite of the offence was that the accused must know or ought to know (because the means of knowledge was available to him) the consequence of what he did (or omitted to do).

\section{(b) $\underline{\text { Analysis }}$}

Lord Bingham considered the early law, as well as the civil remedy. ${ }^{736} \mathrm{He}$ also noted there were numerous statutory offences which now covered what had been common law offences ${ }^{737}$ and

Where Parliament has defined the ingredients of an offence, perhaps stipulating what shall and what shall not be a defence, and has prescribed a mode of trial and a maximum penalty, it must ordinarily be proper that conduct falling within that definition should be prosecuted for the statutory offence and not for a common law offence which may or may not provide the same defences and for which the potential penalty is unlimited...It cannot in the ordinary way be a reason for resorting to the common law offence that the prosecutor is freed from mandatory time limits or restrictions on penalty. It must be assumed that Parliament imposed the restrictions which it did having considered and weighed up what the protection of the public reasonably demanded. I would not go to the length of holding that conduct may never be lawfully prosecuted as a generally-expressed common law crime where it falls within the terms of a specific statutory provision, but good practice and respect for the primacy of statute do in my judgment require that conduct falling within the terms of a specific statutory provision should be

\footnotetext{
${ }^{730}$ Ibid, p 80.

${ }^{731}$ Ibid 'it would still have its Public Health Act powers to suppress a statutory nuisance - which by section 100 of the Public Health Act include the power to take proceedings in the High Court where proceedings in the magistrates' courts would be inadequate. Furthermore, where - as usual - the former public nuisance also constituted some specific statutory offence, the local authority could still use section 222 of the Local Government Act to injoin the defendant from committing that particular offence, if criminal proceedings proved inadequate to bring the problem to an end. Thus abolishing the crime of public nuisance would scarcely leave the public authority dangerously disarmed.'

${ }^{732} \mathrm{Ibid}, \mathrm{p} 81$ 'As the law stands, the chance of a private plaintiff obtaining an injunction in such a case is surely only theoretical, because if he could not show that he was personally affected by the public nuisance it is unlikely that the Attorney-General would lend his name to a relator action. Where the defendant is pursuing an activity that has caused or is threatening damage to the plaintiff's property or person the position is different. Here the plaintiff deserves to win, and at present he can go to court to seek an injunction to stop the activity on the ground that it amounts to a public nuisance, even without joining the Attorney-General in a relator action. But so wide is the modern law of tort he would still get his injunction even if public nuisance was abolished.'

${ }^{733}$ Ibid 'Claims for damages based on public nuisance seem to be rare, and are almost always highway cases. In many of these the outcome would be exactly the same if there was no such thing as public nuisance, and the plaintiff had to base his case on the defendant's negligence.'

734 [2006] 1 AC 459 .

${ }^{735}$ Ibid, p 485.

${ }^{736}$ In particular, he referred, at p 467, to Winfield, Nuisance as a Tort (1932) 4 CLJ 189, Newark, n 220 and Loengard, n 156.

${ }^{737}$ [2006] 1 AC 459 at p 478 et seq.
} 
prosecuted under that provision unless there is good reason for doing otherwise....It follows...that the circumstances in which, in future, there can properly be resort to the common law crime of public nuisance will be relatively rare. ${ }^{738}$

Lord Bingham also noted that the domestic law of England had set its face against 'dog-made' law and noted that there were two guiding principles: (a) no one should be punished under a law unless it was sufficiently clear and certain to enable him to know what conduct was forbidden before he did it; (b) no one should be punished for any act which was not clearly and ascertainably punishable when the act was done. ${ }^{739}$ In particular, in the context of public nuisance, he no longer accepted the cases of Norbury (1978) or Johnson (1997) (re obscene phone calls) nor the inclusion in the crime of public nuisance, matters relating to 'morals.' (i.e. aspects of indecency). ${ }^{740}$

\section{(c) $\underline{\text { Conclusion }}$}

The judgment of Lord Bingham is an excellent one. However, it is asserted that two important matters re public nuisance were not brought to his attention. Matters which - while not affecting the outcome of the cases - do materially impact on the continued worth of this crime: viz.

- $\quad$ Crime Invented by Hawkins. Public nuisance may well have been a generic crime invented by the legal writer, Hawkins (see 17). His error was to 'lump' together other crimes such as an innkeeper refusing board and lodging to a traveller and a person maintaining a bawdy house - without noting that these were separate crimes that did not require any public nuisance as such to be proved. Further, he failed to note that many public nuisances which he was citing had a statutory basis. This was compounded by Russell (in 1819, see 20) adding in indecency, even though that also did not have to be shown to be a public nuisance (though it did have to be shown to have been in public, which is not the same thing). Thus, this crime started off on an incorrect basis and rapidly became a 'legal dustbin' into which legal writers cast crimes they could not otherwise conveniently place elsewhere in their texts (texts which usually aimed for a neat categorisation of the criminal law in accordance with 'their' system);

- $\quad 90 \%$ Covered by Statute. If the House of Lords had required counsel to list in chronological order all the commonly cited cases on public nuisance from even the 18th century, it would have become clear to the court that the common law crime had been supplanted - at least $90 \%$ - by statute (taking out 'moral' material and phone calls). Thus, continued reliance on this common law crime would subvert legislation (including the sentence Parliament had laid down). For his part Lord Bingham listed out various pieces of legislation and he (clearly) realised that there was substantial overlap. He also adverted to the fact the common law crime should not generally be relied on - but, rather, the statutory one (where applicable) - unless there was good reason otherwise. However, if the court had been aware of the full position, it is likely that it would have been even more hesitant in accepting the continued validity of this crime.

In conclusion, it was, perhaps, insufficiently brought to the attention of the House of Lords in Rimmington, the degree to which the crime of public nuisance was supplanted by legislation - as well as the fact that it had been (incorrectly) defined to include what were, actually, distinct common law crimes. Thus, there was much less legal certainty than might be supposed.

\section{THORNTON (2010)}

Thornton, The Law of Public Order and Protest (2010) ${ }^{741}$ stated as to public nuisance:

Historically, the conduct complained of was of a wondrous variety, including erecting a manufactory for hartshorn; ${ }^{72}$ keeping a ferocious dog unmuzzled; and keeping hogs near a public street and feeding them with offal. It also covered the emissions of smoke, noise, and smells from factories and mines. Today a vast swath of regulation exists to prohibit what has been prosecuted as a public nuisance, from the Environmental Protection Act 1990 to the Dangerous Dogs Act 1991. While the courts have no power to abolish the offence, the unanimous opinion of the House of Lords in [Rimmington] was that the most typical and obvious forms of public nuisance were now subject to statutory provision. It would almost always be preferable to prosecute the conduct under statutory law rather than common law, not only because of the primacy of Parliament, but also because statute defined the mode of trial, the maximum penalty, and might provide a statutory defence - all of

\footnotetext{
${ }^{738}$ Ibid, p 479.

${ }^{739}$ Ibid, p 482.

${ }^{740}$ Ibid, p 484. See also Lord Rodger, pp 488-9 re the cases.

${ }^{741} \mathrm{P}$ Thornton, The Law of Public Order and Protest (2010).

${ }^{742}$ OED, n 4(hartshorn) '1. The horn or antler of a hart; the substance obtained by rasping, slicing or calcinating the horns of harts, formerly the chief source of ammonia.' See also n 526.
} 
which were absent from the common law crime. Furthermore, the common law offence should not be employed to avoid time limits or restrictions on penalty. ${ }^{743}$

Thornton also noted that the House of Lords in Rimmington had declined to define public nuisance except by example.

\section{LAW COMMISSION CONSULTATION PAPER (2010)}

In 2010, the LC issued a Consultation Paper, 'Simplification of Criminal Law: Public Nuisance and Outraging Public Decency. ${ }^{.744}$

\section{(a) Term - Public Nuisance}

The LC noted:

The term 'public nuisance' has historically been used in two senses. In a narrow sense, it referred to activities which affect the safety or amenity of an area. In a wide sense it referred to a family of public order offences, including public nuisance proper, outraging public decency and keeping a disorderly house, and several offences now abolished such as being a nightwalker or a common scold. In recent years the tendency has been to confine public nuisance more closely around the environmental category of activities and to treat outraging public decency and keeping a disorderly house as separate offences. All these offences were developed by the King's Bench in the seventeenth and eighteenth centuries in reaction to perceived social evils, ${ }^{745}$ though public nuisance proper also has older roots. They had in common a vagueness of outline and a reluctance to define a fault element, as the purpose was to remove the nuisance rather than to reform the offender. ${ }^{746}$

The LC followed the definition of Archbold ${ }^{747}$ - itself a borrowing from Stephen (see 22) - which definition was approved in Rimmington. Analysing Stephen's definition, the LC found it to be problematic in respect of 'acts not warranted by law or omissions to discharge a legal duty. ${ }^{748}$ As to the second part of Stephen's definition, the LC considered the effect on the public in terms of 'common injury', analysing this in terms of - (1) injury to whom (or to how many) ? (2) what type of injury? (3) how great an injury ? (4) for how long ? ${ }^{749}$

\section{(b) Current Practice $^{750}$}

In respect of current practice, the LC divided (for the purpose of convenience) public nuisance into two categories of nuisance: (a) environmental; (b) behavioural. ${ }^{751}$

- As examples of the latter which had been prosecuted, the LC cited: (i) climbing on cranes (or motorway bridges) as a political protest; (ii) exposure in public, (iii) harassment of females; (iv) disorderly behaviour involving drugs; (v) bomb hoaxes; and (vi) false calls to the police;

- However, the LC noted that - in light of Rimmington (2006) - 'some of these instances may now fall outside the offence ${ }^{152}$ - likely a reference to the observations of Lord Bingham (see 29) that matters

\footnotetext{
${ }^{743}$ Thornton, $\mathrm{n}$ 741, p 77. Thornton continued 'In addition to these limitations on its use, an earlier Law Commission Report had expressed the hope that prosecutors would not feel the need to resort to the offence in public order situations. [Criminal Law. Offences relating to Public Order. Law Com 123 (1983)]. Nonetheless, the door has been left open for occasions where a prosecutor can put forward the 'good reason' for prosecuting the common law offence of public nuisance. The common law principles contained within the offence of public nuisance are entirely consistent with Article 7(1) of the European Convention on Human Rights. The crime is sufficiently defined to meet the not particularly exacting requirements of certainty set by the Convention.'

${ }^{744}$ See $\mathrm{n} 9$.

${ }^{745}$ This statement, with respect, is too wide. All of keeping a disorderly house, nightwalking and being a common scold existed (long) before the 17 th century.

${ }^{746}$ Ibid, para 1.12 .

${ }^{747}$ Ibid, para 2.1. See also $n 8$.

${ }^{748}$ Ibid, para 2.9. 'The first part of the definition, concerning acts not warranted by law or omissions to discharge a legal duty, is problematic. On one interpretation, 'acts not warranted by law' could be confined to unlawful acts in the sense of identifiable offences. At the other extreme, it could mean any act that has the relevant effect of public harm and is not covered by specific statutory authority. Similarly it is not clear whether a 'legal duty' means a specific duty imposed on a person in the defendant's position (e.g. as a public functionary, employer or landowner) or extends to a common law duty of care or indeed the duty of a reasonable use of land as known to the law of private nuisance.'

${ }^{749}$ Ibid, para 2.20 .

${ }^{750}$ The LC cited various cases, which were also considered in their later Report, see 33.

${ }^{751}$ Ibid, para 2.46. The LC cited various statutes, which were also considered in the later Report, see 33.

${ }^{752}$ Ibid, para 2.51 .
} 
relating to morals (i.e. public decency and keeping a disorderly house) were offences separate to public nuisance; and that it was inappropriate for it to include phone calls or bomb hoaxes. ${ }^{753}$

The LC also noted that there were a considerable number of statutory offences which also covered public nuisance at common law. ${ }^{754}$

\section{(c) Analysis of Public Nuisance}

The LC noted the arguments of Spencer for abolishing the offence of public nuisance under the heads of: (i) vagueness of definition; (ii) incompatibility with the constitutional requirement of the rule of law; (iii) problems of compatibility with the European Convention on Human Rights ('ECHR')); (iv) redundancy, as having been superseded by statutory nuisance and other modern statutory offences and mechanisms. As to these:

- Vagueness of Definition. The LC noted that the House of Lords in Rimmington (2006) did not accept Spencer's argument (see 28) that the overall definition of the offence was so platitudinous as not to be a definition at all, so that there was no certainty in relation to any branch of the offence. ${ }^{755}$ The LC, itself, thought that public nuisance 'as developed through the cases up to and including Rimmington, has reached a reasonable degree of certainty.' ${ }^{756}$ although this was not due to prior definitions such as those of Stephen or Archbold. Rather, it was to be found in a historical distinction in the categorisation of public nuisance, ${ }^{757}$

- $\quad$ Formlessness. The LC indicated that this had been cut down by Rimmington, excluding material such as that relating to indecency, disorderly houses, phone calls and bomb hoaxes. ${ }^{758}$ That said, the LC accepted that, ' if one were setting out to devise a criminal code it would be difficult, and probably undesirable in principle, to draft an offence of similar generality. ${ }^{759}$ They also noted the point made in Rimmington by Lord Bingham that, just as the courts had no power to create new common law crimes, they had no power to abolish them; ${ }^{760}$

- $\quad$ Human Rights. The LC noted that the House of Lords in Rimmington (2006) indicated that - from the point of view of human rights and of the rule of law - there was no objection to common law offences provided they could be defined with reasonable certainty. The LC considered that the offence of public nuisance met this test ${ }^{761}$ excluding cases such as obscene phone calls and hate mail;

- Overlap with other Offences. The LC noted that the House of Lords in Rimmington (2006) acknowledged that most instances of public nuisance were now covered by statutory offences but that: 'It does not follow from this that the law of public nuisance is now a dead letter and that the offence has ceased to exist, or even that it cannot lawfully be used when a statutory offence is available. ${ }^{1762}$ The LC cited as an instance where the use of public nuisance was 'legitimate and useful' was the case of Bourgass (2006). ${ }^{763}$ Also, 'It is highly likely that there will

${ }^{753}$ Ibid, paras 2.28 and 2.30 .

${ }^{754}$ Ibid, para 2.52 .

${ }^{755}$ Ibid, para 4.4. It quoted Rimmington [2006] 1 AC 459 per Lord Bingham at $\mathrm{p} 484$ 'I would for my part accept that the offence as defined by Stephen, as defined in Archbold (save for the reference to morals)...is clear, precise, adequately defined and based on a discernible rational principle. A legal adviser asked to give his opinion in advance would ascertain whether the act or omission contemplated was likely to inflict significant injury on a substantial section of the public exercising their ordinary rights as such: if so, an obvious risk of causing a public nuisance would be apparent; if not, not.'

${ }^{756} \mathrm{Ibid}$, para 4.5

${ }^{757} \mathrm{Ibid}$, 'it may be found in the historical distinction...between 'core' nuisance with a clear analogy with private nuisance (the first category) and the miscellaneous forms of misbehaviour classified with it (the second category). The actual decision in Rimmington may be paraphrased by saying that, even in nuisances of the second category, the definitions must be read subject to further unexpressed requirement that the link with 'core' nuisance (the 'intellectual moorings') must not be too remote. It remains the case that nuisance must be defined piecemeal, as similar to nuisances that have been found in the past. The [ECHC] has affirmed the legitimacy of such an exercise, when undertaken by the courts.'

${ }^{758} \mathrm{Ibid}$, para 4.6. 'It is the second category that largely underlies Spencer's complaint of formlessness and extensibility. This category is cut down by Rimmington with the result that the practical application, if not the intellectual force, of that complaint is significantly reduced.'

${ }^{759}$ Ibid, para 4.7.

${ }^{760} \mathrm{Ibid}$, para 4.10 'It is not in my view open to the House in resolving these appeals to conclude that the common law crime of causing a public nuisance no longer exists.'

${ }^{761}$ Ibid, para 4.14 .

${ }^{762}$ Ibid, para 4.18 .

${ }^{763}$ [2006] EWCA Crim 3397. A person compiled recipes and collected materials for the manufacture of ricin and cyanide in circumstances indicating an intention to use them in terrorist activities.' LC 358, n 9, para 4.20 'The appeal was partly against sentence and partly on the question of fair trial: the merits of the choice of public nuisance as an offence were not discussed. In the current climate public reaction to the abolition without replacement of a broad-based offence addressing this type of behaviour is unlikely to be favourable.' Cf. Archbold, $\mathrm{n} 8$, para 31-49' '17 years imprisonment was upheld in the case of an offender who was the prime mover in a conspiracy engaged in over several 
always be a public interest in maintaining an offence that covers analogous kinds of case, if only as a stop-gap as the legislature endeavours to keep pace. ${ }^{764}$

The LC concluded:

Prosecutors, both local authorities and the Crown Prosecution Service, do not make extensive use of public nuisance as a common law offence, preferring to reserve it for extreme and wilful instances of misbehaviour. In answer to questions from the [LC] they have indicated that they wish to keep this weapon in their armoury, as the statutory offences and mechanisms are not always adequate, either in breadth or in gravity, for misbehaviour of this kind. We are inclined to agree that public nuisance still has a role to play in these cases. ${ }^{765^{\prime}}$

The LC provisionally proposed that the offence of public nuisance: (a) be retained; (b) its conduct element should remain in the form as laid down in Rimmington ${ }^{.766}$ (c) the fault element should be revised to require at least recklessness (as well as intentionality) ${ }^{767}$ (d) that it be re-stated in statutory form. ${ }^{768}$

\section{SMITH \& HOGAN (2015), ARCHBOLD (2016) \& BLACKSTONE (2016)}

\section{(a) Smith \& Hogan}

Smith and Hogan (2015) considered the law on public nuisance. Following the definition of Stephen (with excision of reference to 'morals' $),{ }^{769}$ it also noted that:

A person who has suffered particular damage as a result of a public nuisance can maintain an action for damages in tort, and the major importance of public nuisance today is in the civil remedy which it affords. ${ }^{770}$

Noting various cases on public nuisance and the case of Rimmington, Smith and Hogan considered the specifics of the offence. viz. (a) act or omission; (b) nature of interference; (c) the public; (d) mens rea; (e) proof; (f) vicarious liability; (g) ECHR. It also noted the Law Commission's paper of 2010 (see 31) and stated:

The Law Commission in its 2010 Consultation Paper recommended retention of the offence. This conclusion was arrived at because, in the Commission's view, the offence has developed a reasonable degree of certainty. It is based on the 'core' of public nuisance in civil law. That conclusion involves the assumption that one can define a public nuisance in civil law with reasonable certainty. Even if the core can be defined with certainty by reference to the civil law, the question remains whether in terms of the appropriate boundaries of criminalization it is necessary to use criminal sanctions for such conduct. One argument is that it is necessary to use the criminal law to ensure consistency of protection. The view taken is that it may be needed by prosecution agencies and it is to be spared on pragmatic grounds. Although the Commission identified serious cases in which public nuisance has been prosecuted, these are not all strong examples. Numerous statutory offences were available in those cases. ${ }^{771}$

\section{(b) $\underline{\text { Archbold (2016) }}$}

Archbold, Criminal Pleading, Evidence and Practice (2016), ${ }^{772}$ stated:

Public nuisance is an offence at common law. A person is guilty of a public nuisance (also known as common nuisance), who (a) does an act not warranted by law, or (b) omits to discharge a legal duty, if the effect of the act or omission is to endanger life, health, property or comfort of the public, or to obstruct the public in the exercise or enjoyment of rights common to all her Majesty's subjects...

months to commit acts of terrorism (but charged as a conspiracy to cause a public nuisance) involving the use of poisons and explosives intended to destabilise the community by causing disruption, fear and injury.'

${ }^{764}$ LC 358, n 9, para 4.21 .

${ }^{765}$ Ibid, para 4.22 .

${ }^{766}$ Ibid, para 4.27.

${ }^{767}$ Ibid, para 6.1 'We consider that the arguments set out above show that there is no clear case for either abolishing the offence or significantly restricting or altering its conduct element, but that the fault element should be revised to require at least recklessness.'

${ }^{768}$ Ibid, paras $6.8 \& 7.3$.

${ }^{769}$ Smith \& Hogan, n 57 (14th ed, 2015), para 32.11 quoted the description of the Court of Appeal in Goldstein [2004] 2 AE 589 at [3] 'A person is guilty of a public nuisance (also known as a common nuisance) who (a) does an act not warranted by law, or (b) omits to discharge a legal duty, if the effect of the act or omission is to endanger the life, health, property, or comfort of the public, or to obstruct the public in the exercise or enjoyment of rights common to all her Majesty's subjects.' See also, Ashworth [2004] Crim LR 303.

${ }^{770}$ Ibid. It referred to E Peel and J Goudkamp, Winfield and Jolowicz on Tort (19th ed, 2014), ch 15.

${ }^{771}$ Ibid, para 32.11.6.

${ }^{772}$ Archbold, n 8. 
The common law remains important because of its flexibility in adapting to those areas not covered by the special legislative schemes. Where, however, the conduct in question is criminalised by a particular statutory provision, the normal course will be to prosecute for the statutory offence.... ${ }^{773}$

Archbold then considered the actus reus and mens rea of the crime - as well as vicarious liability, conspiracy to commit a public nuisance ${ }^{774}$ and statutory authorisation. Finally, Archbold noted that reference to 'morals' should be struck out in deference to the decision in Rimmington (2006). ${ }^{775}$

\title{
(c) Blackstone
}

Blackstone, Criminal Practice (2016), noted that public nuisance was a common law offence and referred to Rimmington (2006). In particular, it stated:

\begin{abstract}
The torts and the crime are closely connected: 'public nuisance is defined by reference to private nuisance and as differing from private nuisance only in the range of its effect' (Shorrock [1994] QB 279 [see App C])....Where someone suffers particular damage as a result of public nuisance they may sue in tort for public nuisance...[As to nuisance] There must be conduct by the accused which 'renders the enjoyment of life and property uncomfortable' ${ }^{776}$ or 'materially affects the reasonable comfort and convenience of a class of Her Majesty's subjects' ${ }^{777}$.... Not all obstructions of the highway amount to a public nuisance (see e.g. Dwyer v Mansfield [1946] KB 437 and DPP $v$ Jones [1999] 2 AC 240 [see App C]). ${ }^{778}$
\end{abstract}

As with previous texts, Blackstone considered the specifics of public nuisance, viz. act or omission, public nature of the nuisance, mens rea, vicarious liability, defences (statutory authorisation) and compliance with ECHR.

\section{LAW COMMISSION (2015)}

In 2015, the LC issued a Report on the Simplification of Criminal Law: Public Nuisance and Outraging Public Decency. ${ }^{779}$ It did so in the context of considering how these crimes could be re-stated in legislation in a simpler, and more comprehensible, form.

\section{(a) General Points}

The LC stated:

Public nuisance is a tort as well as a crime, and the definitions of the tort and the crime are identical, except that a private individual can sue for the tort only if he or she suffers damage over and above the effect on the general public. Unlike most crimes of comparable seriousness, public nuisance contains no requirement that the defendant intended or was reckless about whether his conduct caused the relevant kind of harm. The fault requirement is the same in the crime as in the tort: namely, that the defendant ought reasonably to have foreseen the consequences of the act or omission. ${ }^{780}$

The LC noted that public nuisance could be based on the defendant's single act, course of conduct or failure to act under a legal duty. ${ }^{781}$ With reference to the pre-requisite of common injury, it also noted that:

the definition in Archbold, and the previous definitions cited in Rimmington [2006] spread the net rather wider than this [common injury] and include anything that endangers the life, health, property, or comfort of the public, without any necessary connection to the local area or an identified public right. For this reason, the offence has been used in cases of hoax telephone calls to the emergency services; persistent telephone calls to a policewoman,

\footnotetext{
${ }^{773}$ Ibid, paras $31-40$ \& 41.

${ }^{774}$ Archbold stated, para 31-45 'Conspiracy to commit a public nuisance remains an offence and is contrary to section 1(1) of the CLA 1977...That such an offence exists was recognised in $R v$ Soul, [see App C] ... Whilst the House of Lords in [Rimmington] appeared to express some doubt about this decision, this was unrelated to the charge of conspiracy.'

775 Ibid, para 31-50.

${ }^{776}$ The quotation was from White $v$ Ward (1775), see App C, per Lord Mansfield at p 337.

777 The quotation was from A-Gv PYA Quarries Ltd [1957] 2 QB 169, approved by the Court of Appeal in Johnson [1996] 2 Cr App R 434.

${ }^{778}$ Blackstone CP, n 61, para B11.83.

${ }^{779}$ LC 358, n 9, para 1.2.

${ }^{780}$ Ibid, para 1.4.

${ }^{781}$ Ibid, para 2.3 .
} 
likely to disrupt the operation of the station switchboard; obscene telephone calls; and accumulating materials for a bomb factory. ${ }^{782}$

\section{(b) Legislation}

The LC noted that legislation had overtaken the common law offence of public nuisance in most instances such as in the case of highway and environmental offences. ${ }^{783}$ They also noted the wide power of local authorities to issue abatement notices ${ }^{784}$ as well as their power to make byelaws for the suppression of nuisances (such as in the Noise Act 1996) ${ }^{785}$ The LC also referred to situations where legislation overlapped with the common law offence, being situations referred to in Rimmington (2006) and in the LC consultation paper of 2010 (see 31), viz.

(i) Public order offences. In particular, violent disorder, affray and threatening or abusive behaviour;

(ii) Other offences of public misbehaviour - such as drunk and disorderly behaviour, harassment, indecent exposure, voyeurism and holding raves in breach of statutory requirements;

(iii) Bomb hoaxes;

(iv) Obstructing the highway;

(v) Postal and communications offences - including sending a substance intending to induce a belief that it wasnoxious, sending through the post anything likely to injure a postal worker or anything indecent or obscene, sending indecent, threatening or false communications and improper use of a public electronic communications network;

(vi) Procedures under the Anti-Social Behaviour Act 2003 - including landlords' remedies for anti-social behaviour, penalty notices for graffiti and fly posting. Also, an offence of failing to comply with a remedial notice about high hedges;

(vii) Anti-Social Behaviour, Crime and Policing Act 2014 - including injunctions against anti-social behaviour, criminal behaviour orders, community protection notices, remedial orders, public spaces protection orders, closure notices and closure orders as well as making provision for landlords and tenants. ${ }^{786}$

\section{(c) Not covered by Legislation?}

When looking at the important issue of what acts had been treated as a public nuisance (by reference to anecdotal evidence from the College of Policing and generally), the LC listed these in their Report (many in a useful box diagram $)^{787}$ in which it also indicated alternative legislation. These are now listed (I have inserted references to other relevant legislation in some cases):

- Highway. (a) obstructing the highway; (b) failing to clear mud outside a farmyard - causing a motorcyclist to lose control of his vehicle and sustain fatal injuries; (c) failing to control horses on a highway, causing a collision. These would appear to be covered by the Highways Act 1980, s $137^{788}$ (if not, they could be so covered by slight amendment);

Bridges, Buildings. (a) hanging or climbing on a bridge; (b) urinating onto a road from a footbridge and throwing things onto the road; ${ }^{789}$ (c) jumping into a river during a boat race; (d) attempting (or threatening) suicide by jumping from a motorway bridge or high building; (e) standing on the wrong side of the barrier on a motorway bridge. ${ }^{790}$ These would appear to be covered by the Highways Act 1980, s 328(1) ${ }^{791}$ (which the LC did not

\footnotetext{
${ }^{782}$ Ibid, para 2.7.

${ }^{783}$ Ibid, para 2.21 referring to Highways Act 1980, s 137. Also, para 2.26 (environment).

${ }^{784}$ Ibid, para 2.29 .

${ }^{785}$ Ibid, para 2.30 'They also have powers under the Noise Act 1996 to issue warning notices for night-time noise, to give fixed penalty notices and in some cases to enter and seize noise-making equipment.'

${ }^{786}$ Ibid, paras 2.32-2.35.

${ }^{787}$ Ibid, para 3.16 .

${ }^{788}$ Highways Act 1980, s 137(1) 'If a person, without lawful authority or excuse, in any way wilfully obstructs the free passage along the highway...' it is an offence. See also s 131(1)(damage to the highway). See also Archbold Procedure, n 62, para 20-97.

${ }^{789}$ Urinating should be an issue of indecency not public nuisance (since no nuisance as such should have to be proved). The Highways Act 1980, s 131(c) covers damaging the highway by depositing things on it. This could be amended slightly to cover depositing things on the road that might endanger it. See also LC 358, n 9, p 29.

${ }^{790}$ In the case of others, there was alternative legislation, see LC 358, n 9, pp 28-33.
} 
mention). If not, they could be so covered by slight amendment - such as jumping (or threatening to jump) onto the highway (including from a bridge) or other act so as to obstruct, or endanger, traffic. ${ }^{792}$ It may be noted that, in early times, bridges were treated as part of the highway in any case (see 14(b));

- $\quad$ Football Match. (a) lighting fireworks and flares at a match; (b) extinguishing floodlights at a match. The first would appear to be covered by the Football (Offences) Act 1991, s $2^{793}$ (if not, it could be so covered by slight amendment). In general, crimes at football matches are dealt with by the Football (Offences) Act 1991 and the Football Spectators Act 1989. Thus, (b) could be added to them (e.g. making it an offence to interfere with sports equipment such as lights, goalposts, seats etc);.

- $\quad$ Anti-Social Behaviour. (a) aggressive behaviour in public; (b) glue sniffing in public; (c) brandishing a knife in public; (d) head-butting care staff; (e) recklessly driving onto a motor racing track; ${ }^{794}$ (f) littering a forest with excrement. There are already crimes relating to harassment, assault and battery, careless driving and possession of a knife. Further, criminal behaviour orders may be secured for the likes of abusing staff and glue sniffing in public. ${ }^{795}$ The case of (f) is more one of public indecency, and should be treated as such, see 36;

- $\quad$ Hoax Call, Abuse. (a) causing a police siege by threatening to blow oneself up or set fire to a house; (b) making a video threatening to bomb; (c) a hoax call to a charity; (d) a hoax bomb call; (e) abusive emails to a police officer; (f) a group making videos of themselves abusing elderly persons in public; ( $g$ ) threatening to drink weed killer. Bomb hoaxes are governed by the Criminal Law Act 1977, s $51^{796}$ and other calls of harassment should not, following Rimmington, be dealt with by way of public nuisance;

- $\quad \underline{\text { Others. }}$. (a) exposing oneself while urinating in public; (b) substituting a drug in a chemist's shop; (c) hosting an acid house party; (b) causing damage at a rave. Intentional exposure of the genitals is covered by the Sexual Offences Act 2003, s $66^{797}$ and, in any case, it is more one of public indecency, and should be treated as such, see 36. The removal of persons at a rave is dealt with by the CJPO Act 1994, s $63 .{ }^{798}$

The LC also noted that - in some cases - sentencing powers appeared to fall well short of what was required (e.g. failing to control horses, hoax calls to charities, videoing elder abuse). ${ }^{799}$

- This analysis is very useful since it indicates that there are very few instances where acts of public nuisance are not otherwise covered by legislation. Further, if one makes reference to all the cases referred to in legal texts since the 18th century, see App C, and, indeed, even those prior to the 18th century from medieval times, these are now obsolete or are covered by legislation (including in the 1839 and 1847 Acts);

- As to any acts referred to above not presently covered by legislation, they are more relevant to the crime of public indecency or they could be included in anti-social legislation, with minor amendment.

In conclusion, the only examples of public nuisance the LC cited which it did not think covered by legislation related to bridges. However, this would appear to be covered by the Highways Act 1980, s 328(1).

\section{(d) $\underline{\text { LC Conclusion }}$}

The LC concluded that there was a need for an offence of public nuisance but that the existing common law offence should be replaced by a statutory one. Thus, it proposed that a new offence of intentionally (or recklessly) causing a public nuisance. One to cover:

(1) voluntary conduct by the defendant - including omissions, where the defendant was under a duty at common law or by statute;

\footnotetext{
${ }^{791}$ Highways Act 1980, s 328(1) 'In the Act, except where the context otherwise requires 'highway' means the whole or part of a highway other than a ferry or a waterway. (2) where the highway passes over a bridge or through a tunnel, that bridge or tunnel is to be taken for the purposes of this Act to be part of the highway.'

${ }^{792}$ See also RTA 1988, s 222A(1)(a) 'causing anything to be on or over a road...in such circumstances that it would be obvious to a reasonable person that to do so would be dangerous.' See also LC 358, n 9, p 29.

${ }^{793}$ Football (Offences) Act 1991, s 2 (throwing of missiles). See also Archbold Procedure, n 8, para 16-148.

${ }^{794}$ LC 358, n 9, p 30.

795 See Anti-Social Behaviour, Crime and Policing Act 2014. See also Anthony [2005] EWCA Crim 2055 (abusing staff).

${ }^{796}$ See Criminal Law Act 1977, s 51(2). See also Archbold Procedure, n 62, para 16-269 to 271. See also LC 358, n 9, pp 28-33.

${ }^{797}$ Section 66(1) provides that 'A person commits an offence if (a) he intentionally exposes his genitals; and (b) he intends that someone will see them and be caused alarm and distress. '

${ }^{798}$ CJPO 1994, s 63. See also Archbold Procedure, n 62, para 16-235 to 239 (powers to remove persons attending or preparing for a rave). See also CJPO Act 1994, s 77 (directing unauthorised campers to leave land). See also LC 358, n 9, p 32.

${ }^{799}$ Ibid, para 3.21. Also, para 3. 25 (person who causes a police siege by threatening to burn his house down).
} 
(2) conduct which causes: (a) serious harm to members of the general public (or a section), or (b) obstruction to the public (or a section) in the exercise or enjoyment of rights common to the public at large;

(3) where the D intended that conduct to cause, or was reckless as to whether it would cause, (a) serious harm to members of the general public (or a section); or (b) obstruction to the public (or a section) in the exercise or enjoyment of rights common to the public at large - unless D's conduct was reasonable in the circumstances as he (or she) knew or reasonably believed it to be. ${ }^{800}$

There would be a saving provision that nothing in the statutory offence was to prejudice the availability of any civil procedure or affect the meaning of nuisance in any other statute. ${ }^{801}$

\section{(e) Conclusion}

It is asserted that the recommendation of the $\mathrm{LC}$ is a perfectly reasonable one - given the current presence of other crimes which make it uncertain whether all acts covered by public nuisance would be otherwise covered were it abolished. However, if these other offences were abolished - and the Acts of 1839 and 1847 were abolished (with such sections on public nuisance as are useful becoming general law) there is no need for a statutory offence of public nuisance. As it is:

- $\quad$ All Acts Covered. If one considers all the cases on public nuisance (see App A) and all the acts referred to by the LC in (c) above, the vast majority are now covered by legislation - probably to the extent of $95-98 \%$. Thus, there is no need for a public nuisance offence as well;

- $\quad$ Public Nuisance is Anti-Social Behaviour. In early times, nuisance and annoyance meant the same thing and common nuisance meant that it was anti-communal activity which, if not punished, would likely lead to a breach of the peace. ${ }^{802}$ This point has been forgotten. Thus, public nuisance is one and the same as our reference to 'antisocial behaviour' and, therefore, there is no need for a separate description with the existence of anti-social legislation;

- $\quad$ Sentence not Enough. In some cases, the LC noted that the sentencing powers appeared to fall short of what is required. They mentioned failing to control horses, hoax calls to charities, videoing elder abuse. The remedy is to augment the sentence - not to create a new crime;

- $\quad$ Not Covered? As to the (very few) offences the LC note are not otherwise covered these can easily be inserted into current legislation on the highways, football matches etc. And the remainder are classic anti-social offences which should be specifically covered under the Anti-Social Behaviour Act 2003 or are indecency offences.

Further, since public nuisance also is a tort, then the same process should be adopted as in the case of scandalum magnatum and criminal libel. In prior times, it was a crime to libel 'great men' (scandalum magnatum) or to libel others. However, by Victorian times, it was very rare for people to be put in prison for this and fines were, also, often low. ${ }^{803}$ Thus, more and more people resorted to the civil remedy instead, since they could assuage their anger by recovering damages. As a result, these crimes were abolished. This was of benefit to the State, since it saved the cost of public prosecution and of putting people in prison. It was also a more efficacious remedy. Abolishing the crime of public nuisance would be the same. As well as preventing overlap with other crimes (mainly statutory), the civil remedy is more efficacious since, doubtless, people would be less likely to repeat the act if the financial penalty was greatly higher. Thus, it is asserted that consideration be given to the following. As well as abolishing the crime of public nuisance:

- $\quad \underline{\boldsymbol{A}-\boldsymbol{G}}$. The A-G should have the right to prosecute any public nuisance at civil law (as well as any person specially affected being able to do so);

- Highway Authority. They should have the authority to prosecute public nuisance acts involving a: (a) bridge; (b) highway; (c) footpath (see examples above);

\footnotetext{
${ }^{800}$ Serious harm to the person meant that a person suffered: (a) death, personal injury or disease; (b) loss or damage to property; (c) serious distress, annoyance, inconvenience or loss of amenity; or was put at risk of suffering any of those things.

${ }^{801}$ LC 358, n 9, ch 4.

${ }^{802}$ See e.g. Ibbetson, n 210 'public nuisance was concerned with the antisocial nature of the [D's] behaviour.' Also, Loengard, n 156 , p 164 (anti-social acts).

${ }^{803}$ See GS McBain, Abolishing Criminal Libel, (2010) ALJ, pp 501-4 (table of caselaw).
} 
- $\quad$ Other Government authorities. Other relevant Government authority should be able to prosecute public nuisance acts involving (a) football matches; (b) rivers and waterways; (c) public buildings (including courts);

- $\quad$ Spitting, Urinating, Defecating. These are matters of indecency and should be covered by a statutory crime of public indecency (see 36). Thus, spitting (which is a crime under some local legislation), urinating and excreting in public (without reasonable cause) should be a crime - with (perhaps) an aggravated sentence when on public buildings (including war memorials). Making it a crime separate to public indecency enables it to be more clear, as well as more specific $r e$ the sentence.

In conclusion, consideration should be given to abolishing the crime of public nuisance and augmenting the civil position - once other offences connected to the crime of public nuisance are considered and abolished (see 35).

\section{PUBLIC MISCHIEF}

A brief word should be said about this offence and its relationship to public nuisance. Archbold (2016) presently states: ${ }^{804}$

The common law of effecting a public mischief, if it ever existed, has certainly ceased to do so: see $R v$ Newland $[1954]^{805}$...Furthermore, conspiracy to effect a public mischief, in the sense of an agreement to do an act which, although not unlawful in itself, is extremely injurious to the public, is not an offence known to law: DPP $v$ Withers $[1975]{ }^{806}$

However, public mischief overlapped with public nuisance. The best modern summary is contained in the last edition of Russell in $1964{ }^{807}$ which cited the following cases:

- Osborn (1732) ${ }^{808}$ The court made absolute a rule for an information against $\mathrm{O}$ who published a scandalous libel against an undefined body of Jews on the basis that, although too general to fall within the definition of a libel, 'it will be pernicious to suffer such scandalous reflections to go unpunished. ${ }^{809}$ Although Russell treated this as an example of public mischief, it was generally treated as a criminal libel, ${ }^{810}$ which crime has now been abolished by the Coroners and Justice Act 2009. Today, the offence would be of inciting racial hatred under the Public Order Act 1986;

- Higgins (1801) ${ }^{811}$ Lawrence $\mathrm{J}$ stated that: 'all offences of a public nature, that is, all such acts or attempts as tend to the prejudice of the community' were indictable. This was obiter. It also did not reflect the state of the law prior to it being stated, being too wide in scope;

- Williams $v$ East India Co (1802). ${ }^{812}$ Ellenborough CJ spoke of 'a species of delinquency in the persons concerned...for which they are criminally liable, and punishable as for a misdemeanour at least. ${ }^{1813}$ The case concerned putting of highly inflammable articles (oil and varnish) on board a ship without telling those managing it. The articles caught fire, resulting in the ship's loss;

\footnotetext{
${ }^{804}$ Archbold, n 8, para 28-198.

${ }^{805}$ [1954] 1 QB 158 .

${ }^{806}$ [1975] AC 842. See also Stephen, n 54, vol 3, p 359 (writing in 1883 re the creation of new offences at common law) 'Though the existence of this power as inherent in the judges has been asserted by several high authorities for a great length of time, it is hardly probable that any attempt would be made to exercise it at the present day; and any such attempt would be received with great opposition, and would place the bench in an invidious position.' See also WTS Stallybrass Public Mischief, ch 5 \& RM Jackson, Common Law Misdemeanors, ch 16 in The Modern Approach Criminal Law (1945). Also, Johnson (1678) 2 Show 1 (89 ER 753)(agreeing to pay a person to prove a deed to be forged, so as to obtain a verdict, was a crime)

${ }^{807}$ Russell, n 3, vol 2, ch 92, pp 1394-6.

${ }^{808}$ (1732) 2 Barn KB 138 (94 ER 406, 425).

${ }^{809}$ Russell, n 3, vol 2, ch 92, pp 1394.

${ }^{810}$ See McBain, n 803, pp 473-4 and fns.

811 (1801) 2 East 4 (102 ER 269) at p 21. The case concerned inciting a servant to steal his master's goods. It was held to be a misdemeanour. See also Spencer, n 3, p 62 .

${ }^{812}$ (1802) 3 East 192 (102 ER 571). For Dixon (1814), see App C (in Brailsford [1905] 2 KB 730 the A-G cited it as an example of public mischief. However, it is generally taken as an example of cheat). See also Spencer, 3, p 62. He also referred, Ibid, to De Berenger (1814) 18143 M \& S 67 (105 ER 536)(spreading false rumours re Napoleon's death to increase share price). Ellenborough LC described this as a conspiracy to effect a public mischief. However, this would have been better covered by the crime of eavesdropping, see 12(e).

${ }^{813}$ At p 201
} 
- $\quad$ Bean (1842). For firing a pistol in the direction of Queen Victoria, ${ }^{814}$ Lord Abinger stated 'That your attempt is highly criminal, and that you have been guilty of an abominable crime, no man can doubt.' Shortly after this case doubtless as a result of concerns at finding such a person guilty of high treason - the Treason Act 1842, dealing with assaults on the sovereign, was passed to cover such an act; ${ }^{815}$

- $\quad$ Bassey (1931) ${ }^{816}$ The appellant had been convicted of conspiracy. It appeared he had made arrangements with another whereby forged documents were issued to enable him to gain admittance as a student to the Inner Temple. He was convicted of an act tending to public mischief. The Court of Criminal Appeal held that it was a public mischief to deceive the Benchers of the Inn as the body responsible for admitting students. As it is, the act was more closely related to forgery, cheat (deceit) or fraudulent misrepresentation. ${ }^{817}$ Thus, there was no need to prosecute for public mischief;

- $\quad$ Manley (1933) ${ }^{818}$ The appellant falsely claimed to police that she had been attacked and robbed, resulting in a waste of police time. Convicted of effecting a public mischief. Hewart CJ stated 'We think that the law remains as it was stated by Lawrence J in Rv Higgins.' [see above]. Also, 'all such acts or attempts as tend to the prejudice of the community are indictable. ${ }^{819}$ Today, this is a separate crime. ${ }^{820}$ In any case, it would have been better prosecuted as an example of interfering with the course of justice ${ }^{821}$ or cheat (deceit) which latter was very widely defined; ${ }^{822}$

- $\quad$ Leese \& Whitehead (1936). ${ }^{823}$ The proprietor and printer of a newspaper, the Fascist, were acquitted of seditious libel, but convicted of public mischief, in publishing comments which reflected on the Jewish community as a whole, with intent to create ill-will between Jews and non-Jews. Today, seditious libel has been abolished and the offence would be that of inciting racial hatred under the Public Order Act $1986,{ }^{824}$

- $\quad$ Young (1937). ${ }^{825}$ The accused was convicted of conspiracy to effect a public mischief by giving false progress reports of the erection of public air-raid shelters. It is asserted the accused should have faced internal sanctions (or civil liability, on the basis of false misrepresentation, if it led to loss) for this act and not been held guilty of a crime. And, if prosecuted under criminal law, it should have been for cheat;

- $\quad$ Newland (1954). ${ }^{826}$ Goddard CJ stated 'It may be that Manley's case [see above] will some day be considered by the House of Lords and in any case we venture to think that it would be a useful reform if such conduct as was there disclosed were made a summary offence by the legislature. We do not further enlarge upon it, as the charge we are now considering is one of conspiracy, except to say that in our considered opinion the safe course is no longer to follow it.' 827

\footnotetext{
${ }^{814}$ Bean (1842) 4 St Tr (NS) 1382. See also Kenny, n 55 (last ed, 1966), p 421 'Lord Abinger, in addressing a youthful prisoner who from his place in the crowd had pointed an old pistol in the direction of the carriage of Queen Victoria which was proceeding at a rapid pace far out of range of the weapon (which indeed was not properly loaded), said 'That your attempt is highly criminal, and that you have been guilty of an abominable crime, no man can doubt'. Holding that the offence was short of high treason his lordship declared that all the court could do was too pass 'that sentence which the common law justifies', and sentenced Bean to 18 months imprisonment.' Kenny also noted 'A few days after this case Sir Robert Peel introduced the measure which became law as 5 and 6 Vict [Treason Act 1842], a course which suggests that some doubt was felt as to the propriety of the law expounded by Lord Abinger.'

${ }^{815}$ See also GS McBain, High Treason: Killing the Sovereign or her Judges (2009) 20 KLJ 457-88, especially 468

${ }^{816}$ (1931) 22 Cr App R 160.

${ }^{817}$ See also Stallybrass, $n$ 806, p 68. Cheat was abolished by the Theft Act 1968, s 32.

818 (1933) 1 KB 529. See also Kenny, n 55, p 422.

${ }^{819}$ Cf. Kenny, n 55, p 422 described this as 'a sweeping statement which opens the door to an indefinite multiplication by the judiciary of criminal offences.' A similar case was not upheld by Humphreys J at the Derby Assizes in November 1932, see Stallybrass, n 806, p 72. Ibid, pp 75-6.

${ }^{820}$ Russell also cited Police v Brown [1956] Crim LR 568 (wasted police time with false phone message re supposedly stolen lorry. Held an offence under the Post Office Act 1953, s 66. Fined £ 5) and Bailey [1956] CLY 2069. See also Kenny, n 55, p 423.

${ }^{821}$ Russell, n 3, vol 2, ch 92, p 1395 noted in fn 16 that - in Sykes $v$ DPP [1962] 528, 562 - Manley was classed as an instance of 'interfering with the course of justice.' See also the House of Lords in Shaw v DPP [1961] 2 WLR 897, especially 917 and 918. Also, p 921 (per Lord Reid).

${ }^{822}$ Ibid, ch 70, pp 1155-65, especially cases referred to on p 1156. See also, for the wide nature of cheat in earlier times, Burn, $\mathrm{n} 11$, (23rd ed, 1820), pp 467-70.

${ }^{823}$ (1936) LJ (News) 310 and Times, 19 and 22 September 1936. See also Kenny, n 55, p 423. Also, Stallybrass, n 806 , p 76.

${ }^{824}$ See also GS McBain, Abolishing the Crime of Sedition: Part 2 (2009) ALJ 449-85 at p 472.

825 (1937) Journal of Criminal Law, vol 1, p 172. See also Kenny, n 55, p 423.

${ }^{826}$ [1954] 1 QB 158 .

${ }^{827}$ At p 168 .
} 
- Joshua (1955). ${ }^{828}$ A judgment of the Court of Appeal of the Windward and Leeward Islands was reversed by the House of Lords in which the accused had been charged with making a seditious speech as well for public mischief in respect of the same. Without deciding whether the latter crime existed, the judgment was reversed on the basis that there was no evidence to go to the jury;

As can seen, certain crimes relating to these matters - such as in respect of criminal and seditious libel - no longer exist. Others are now covered by legislation (Treason Act 1942 and in respect of wasting police time). Indeed, the heart of the crime of public mischief was embraced by cases such as Bassey (1931) and Young (1937) which are, actually, instances of the crime of cheat. Thus, public mischief was, effectively, that crime under another name. As it is, it has been held that public mischief (or any conspiring to commit the same) no longer exists as a crime. However, it should be abolished by legislation to make this clear. For present purposes, even if public mischief is abolished, there is no reason that the acts formerly embraced within it should, now, be treated as examples of public nuisance.

\section{In conclusion, public mischief should be (formally) abolished.}

\section{ABOLISHING PUBLIC NUISANCE}

The present problem with our criminal law is that there are too many:

- $\quad$ crimes - many of which overlap;

- obsolete crimes (both legislative and at common law);

- $\quad$ criminal legislation (at least, 286 Acts now cover criminal law and procedure);

- common law crimes - all of which should now be statutory.

Common law public nuisance is an excellent example of this. It is inter-connected with many other common law crimes - crimes which should be abolished. It is also inter-connected with local legislation - legislation which should be modernised and become general legislation. Thus, it is asserted the following should be abolished:

- $\quad$ Public Mischief. The House of Lords has held that this crime no longer exists. However, since the courts cannot abolish common law crimes themselves, it should be formally abolished by statute. If abolished, there is no need for public nuisance to cover the matters previously covered by public mischief, since they are either obsolete or covered by other crimes. Abolishing public mischief means that it will not then be resurrected in the future under another name;

- Common Innkeeper refusing Board \& Lodging. This was a separate common law crime. It was Hawkins who, incorrectly (in 1716-21), categorised it under the generic concept of common nuisance (see 17). It still exists, but it is very rare and it is adequately covered by the civil remedy. If abolished, there is no need for public nuisance to cover it;

- Disorderly House. This was a separate common law crime to deal with brothels. It was Hawkins who, incorrectly (in 1716-21), extended it to embrace other matters - all now covered by legislation (gaming and betting houses, theatres (playhouses), places of entertainment, cock fighting pits etc). Today, brothels are covered by the Sexual Offences Act 1956. If the common law crime is abolished, there is no need for public nuisance to cover it.

If these other crimes are abolished, it permits an easier analysis of the crime of public nuisance. Further assistance will be provided by making local Acts dealing with public nuisance crimes, general. Thus,

- $\quad$ Acts of $1839 \&$ 1847. These are limited in scope - the 1839 Act being limited to the MPD and the 1847 Act to urban districts. Further, the 1839 Act contains (anomalously) offences which were also in the 1847 Act and which have been recently repealed. Both these Acts should be repealed and any offences worthy of retention (see App B) should be placed in general legislation - not least since none of these crimes can be committed in the City (because the relevant Act - the City of London Police Act 1839 - has been repealed). If that is not justice by reference to a postal code, what is?

If all the above are dealt with, two other matters need to be considered:

- Unlawful Treatment of Dead Bodies. Some acts concerning the failure to bury a corpse or dis-interring the same were treated as aspects of public nuisance or public indecency (see App C and D). They are better viewed as distinct crimes relating to unlawful treatment of the dead - which crimes should now be placed in (burial) legislation;

${ }^{828}$ [1955] AC 121. See also Kenny, n 55, p 423. 
- Indecency. It appears to have been Russell (in 1819, see 20) who included acts of indecency as a public nuisance. However, this seems palpably incorrect since indecency was, for a long time, an ecclesiastical offence (not one which might affect the 'peace'). Further, as may be seen from the indictments (e.g. Chitty in 1824 , see 20) indecent acts were not pleaded as being a common nuisance. Doubtless, because they are alleged to be offensive per se and, thus, require no evidence of common injury. Also, there are added good reasons. Vicarious liability (which is found in public nuisance) is not appropriate. Nor the potential of a sentence of life imprisonment and/or an unlimited fine.

If all the above were cleared out of the way then - at last - one can secure an un-impeded view of the crime of public nuisance and consider whether it is needed. Assuming all the above are dealt with, it is asserted this crime should be abolished - principally, for the following reasons:

- $\quad$ Never was a Crime. It is dubious there ever was - in early times - a common law crime of public nuisance. Rather, there were distinct crimes, punished on the rationale that they caused a nuisance to the general public. Further, the vast majority of these were statutory crimes - not common law ones. Thus, they were contained in secondary legislation such as Assizes. Or, in Ordinances, as in the case of the City. This happened early on, in the period 1266-85. Thus, one would assert it was Hawkins (in 1716-21) who promoted the idea of 'common nuisance' being a crime (as he did with contempt of the sovereign) and the courts (perhaps unwisely) latched on to this, without noticing that Hawkins was, generally, unfamiliar with early law and had never checked the position in respect of the City (with other cities and towns later acquiring the right to punish such nuisances by charter or local legislation);

- Covered by Other Crimes. A review of all acts said - at one time or another - to be public nuisances from the 18th century (and before) indicates that they are either now not crimes or they are covered by other common law or legislative crimes. At least, up to $95-8 \%$ (see App D). Thus, it is not appropriate to retain this common law crime. Nor is there a need for a statutory one since it will simply become 'dog law'. That is, a crime availed of when judges want to punish any act they disapprove of, not otherwise covered by the common law or legislation. Further, such will undermine the statutory crime - not least in relation to the sentence;

- Life Imprisonment. The punishment for this offence is, potentially, life imprisonment and an unlimited fine. ${ }^{829}$ This is out of kilter with the acts it covers;

- Vicarious Liability. A person can be held to have committed this crime on the basis of the act of his servant - even if unaware of this or if he expressly prohibited it. This is inappropriate in modern times; ${ }^{830}$

- $\quad$ Civil Liability. The A-G (or a local authority) can apply for an injunction to remove a public nuisance. Also, a private person can bring civil proceedings (in tort) seeking damages or an injunction (or both) if he has suffered special damage. It is better for public nuisance to be dealt with civilly since the criminal sanctions are either never employed today (that is, imprisonment) or they are inadequate (in the caselaw, the fine imposed for a public nuisance was, usually, scant);

- $\quad$ Tabula en Naufragio. Spencer asserted that this crime was availed of when the court could think of nothing else to punish reprehensible conduct with or where the sentence was otherwise insufficient. ${ }^{831}$ Thus, for example, in Rimmington, it seems it was availed of since the statutory time bar under the Postal Services Act 2000 had run out. Also, to secure a heavier sentence, if possible. ${ }^{832}$ These grounds are not creditable.

It is asserted that abolition of public nuisance - as well as the other crimes referred to in $\mathbf{3 5}$ - will be positive. It will simplify the law. It will also get remove a ponderous - and inaccurate - caselaw.

\footnotetext{
${ }^{829}$ See also LC 358, n 9, para 2.20 'As in all common law offences where statute does not provide to the contrary, when it is tried in the Crown Court there is an unlimited power of imprisonment.'

${ }^{830}$ Williams, n 58, p 268 'A master was, and still is, vicariously responsible for a common-law public nuisance (though not generally for a statutory nuisance) committed by his servant. He cannot defend himself by showing that he expressly forbade the act. The rule is anomalous, but is supposed to be justified on the ground that the proceeding, though criminal in form, is 'really' civil. Its primary object is not punitive but remedial....Indeed, the law might be rationalised by saying that the apparent vicarious responsibility of the master is in truth a responsibility for negligence in allowing a nuisance or failing to abate a continuing nuisance; but this has not been judicially stated.'

${ }^{831}$ See n 720 .

${ }^{832}$ [2006] 1 AC 459 per Lord Rodger at pp 490-1. See also $R v J$ [2005] 1 AC 562.
} 


\section{PUBLIC INDECENCY}

If public nuisance is abolished, what of outraging public decency? Should it exist? This offence has only surfaced relatively recently and - as can be seen from the caselaw (see App D) - the vast majority of it covers indecent exposure, including naked bathing.

\section{(a) History}

As regards this crime, much depends on the age. In the case of the Germans, Tacitus mentioned the chastity of the women ${ }^{833}$ and the naked dancing of the men. ${ }^{834}$ Presumably, the latter continued in Anglo-Saxon England for a time.

- As it is, Anglo-Saxon law (what we know of it) - although it mentions rape, adultery, fornication, incest, prostitution and indecent assault on women - does not refer to any crime of public indecency. ${ }^{835}$ Likely, naked bathing (segregated) in streams and rivers was common;

- Further, it is clear that 'moral' offences were dealt with ecclesiastically. ${ }^{836}$ Post-Conquest, this appears to have continued and the (asserted) Laws of Edward the Confessor (likely, written c. 1140) and of William I (1066-87) do not indicate crimes re indecency. Nor do the Laws of Henry I (c. 113). So too, in Glanvill (c.1189), Bracton (c. 1240), Britton (c. 1290), Fleta (c. 1290) and the Mirror of Justice (c. 1290).

The absence of this any common law crime(s) of public indecency is understandable for various reasons:

- Most people would have lived in small villages or on isolated farmsteads, their houses with palisades, ensuring privacy; ${ }^{837}$

- Men (or women) who went about naked in the street, for example, would (likely) have been treated as mad and would have been detained by their families (such detention was not treated as battery); ${ }^{838}$

- A degree of nudity in children and men bathing and (possibly) women bathing in rivers - as well as sexual activity in fields and woods - must have been tolerated.

Further, one assumes that most 'indecent' acts - if punished - would have been dealt with within the family (or local community) without producing any legal effect. Thus, it is noteworthy that the jurisdiction of the sheriff's tourn and the court leet do not refer to indecency. Further, while the Ordinances of the City (see 11 and 12) suppressed prostitution as well as - to a lesser extent - adultery and fornication, they made no reference to public indecency (or a crime in respect thereof). In later times, there is some evidence the Star Chamber may have punished 'lewd' activity. However, the extent is not clear and the lack of reports of their proceedings prevents further analysis. ${ }^{839}$ Thus, public indecency (excluding adultery and fornication, to a limited extent) was, effectively, an ecclesiastical crime until after the Restoration. Indeed, it was not until the 19th century (see App D) that criminal cases on indecent behaviour really commenced - such as the punishment of naked bathing which arose due to upper (and middle) class persons building homes close to the sea. As Paterson,

\footnotetext{
${ }^{833}$ Tacitus, $\mathrm{n} 75$, pp 115-7 'For all that, marriage in Germany is austere, and there is no feature in their morality that deserves higher praise. They are almost unique among barbarians in being satisfied with one wife each....the German women live in a chastity that is impregnable, uncorrupted by the temptations of public shows or the excitements of banquets. Clandestine love-letters are unknown to men and women alike. Adultery in that populous nation is rare in the extreme, and punishment is summary and left to the husband. He shaves off his wife's hair, strips her in the presence of kinsmen, thrusts her from his house and flogs her through the whole village. They have, in fact, no mercy on a woman who prostitutes her chastity. Neither beauty, youth nor wealth can find the sinner a husband. No one in Germany finds vice amusing, or calls it 'up-to-date' to debauch or be debauched.' As for homosexuality, it may have been covered by Tacitus' statement, Ibid, p 110 , 'the unnaturally vicious are drowned in miry swamps under a cover of wattled hurdles.'

834 See n 97.

${ }^{835}$ The laws refer to seizing a maiden (unmarried woman) or a nun by the breast, see e.g. Attenborough, n 20, pp 71, 73 (Laws of Alfred). Presumably, this refers to sexual assault in some way.

${ }^{836}$ See JT McNeill \& HM Gamer, Medieval Handbooks of Penance (NY, 1965). The way the church dealt with sins of indecency likely influenced the secular position. Thus, the influential Penitential of Theodore - said to be by Theodore of Tarsus, archbishop of Canterbury (668-90) - distinguished between fornication and adultery (a heavier sentence being imposed for sins of the latter). The former included fornication with: (a) virgin (penance 1 year); (b) married woman (4 years); (c) man (10 years); and (d) animal (10 years or, possibly, 15 years). It also included female homosexuality, masturbation, oral sex and incest. See pp 184-6. No distinction was made between private and public acts. Given all this, it is unsurprising that a secular crime of 'public indecency' took a long time to develop.

${ }^{837}$ See 3(b).

${ }^{838}$ See e.g. 22 Edw 3 Lib Ass 56 fo 98a (1348). Seipp no 1348.264ass referred to in GS McBain, Modernising the Common Law Offences of Assault and Battery (2015) International Law Research, vol 4, no 1, p 58, fn 187.

${ }^{839}$ See n 425.
} 
Commentaries on the Liberty of the Subject and the Laws of England relating to the Security of the Person (1877) ${ }^{840}$ stated:

The law goes to the length of punishing to some extent any wanton indecency committed in public places. The degree of propriety requisite must vary in different ages; and conduct which would not be indecent at one time may well become indecent under a state of civilisation which has adopted a higher standard of delicacy. ${ }^{841}$

\section{(b) Nature of the Crime}

The LC discussed public indecency in 2015, noting that prosecutions were relatively rare ${ }^{842}$ and that it covered sexual acts in public, viz.

1. Exposing the genitals (indecent exposure);

2. Masturbation;

3. Real (or simulated) sex;

4. Making intimate videos without consent (including up-skirting) - which is also covered by 5;

5. Intimate filming of women without consent (it should include men as well);

6. Indecent pay-view exhibitions; ${ }^{843}$

7. Nude bathing in inhabited areas (cf. where permitted).

As to these 1-5 may be covered by the term 'sexual act' and 7 involves 1 . The LC also noted that the caselaw, in the past, included:

8. A magazine containing contact adverts for gay men; ${ }^{844}$

9. The sculpture of a human head with freeze-dried human foetuses as earrings;

10. Dis-interring a corpse for dissection;

11. Exhibiting a picture of sores (cf. a vagabond displaying sores under the Vagrancy Act 1824);

12. Procuring girls to be prostitutes;

13. Urinating on a war memorial.

However, as to these, the following may be noted:

- Duplication. There is no need for 9 and 10 to be treated under this crime, since it is more appropriate for these to be covered by crimes relating to the unlawful treatment of the dead. Further, 12 is better treated in relation to the law on prostitution and 8 should not be subject to criminal prosecution. As for 11, this is inappropriate for public indecency since it should require evidence of the act being of sufficient nuisance to the public to merit criminal sanction. There appears, in any case, only to have ever been one case (Grey (1864) see App C) which is generally treated as one of public nuisance as opposed to public indecency. Further, today, the absence of such cases suggests that such matters are adequately regulated by advertising standards legislation;

- Indecency. No 13 is an anti-social act rather than one of sexual indecency. As previously mentioned (see 33(c)), it would seem better for spitting, urinating and excreting in public (without reasonable excuse) to be a distinct crime. This would enable a tailor-made sentence as well as recognising that it should be punished as much on the basis of hygiene as on the basis of causing offence to the public;

- Pay View Exhibitions. There is legislation on sex establishments, the Local Government (Miscellaneous Provisions) Act 1982 (Control of Sex Establishments). Thus, public indecency cases on this, relating to public sex exhibitions (see App D, cases of Saunders (1875) and Sargeant (1875)) should be dealt with in this legislation;

- Sexual Offences Act 2003, s 66. This makes it a crime where a person intentionally exposes their genitals. ${ }^{845}$ Thus, it covers the majority of all cases on public indecency - including nos 1 and 7 above.

Given this, is it worth retaining the crime of public indecency (or having a statutory crime) if it will conflict so much of the time with other legislation?

\footnotetext{
${ }^{840} \mathrm{~J}$ Paterson, Commentaries on the Liberty of the Subject and the Laws of England relating to the Security of the Person (Macmillan, 1877). See also L Stone, The Family, Sex and Marriage in England 1500-1800 (Penguin, 1977) for evidence of various sexual practices.

${ }^{841}$ Ibid, vol 2, p 362.

${ }^{842}$ LC 358, n 9, paras 2.37 and 3.92-4.

${ }^{843}$ See App D.

${ }^{844}$ Ibid. The LC thought this would not be so included today.

${ }^{845} \mathrm{~s} 66$ (1) 'A person commits an offence if (a) he intentionally exposes his genitals, and (b) he intends that someone will see them and be caused alarm or distress.'
} 


\section{(c) Conclusion}

The LC proposed a statutory crime of outraging public decency. ${ }^{846}$ It would require:

an act or display that is: (1) obscene or disgusting; (2) to an extent sufficient to outrage minimum standards of public decency as judged by the jury in contemporary society.

The LC also recommended that: (i) the act or display must be in a place accessible to (or within) view of the public; (ii) that the crime not have a requirement that 2 persons are present at the place of the act or display; (iii) that the crime not have a requirement that D's conduct resulted in a risk of causing disgust (or annoyance) to members of the public; (iv) that the crime include a fault element; (v) that the crime contain a defence of reasonableness. All of these seem reasonable. However, is there a need for such a crime in such wide terms?

- $\quad$ 'Disgusting.' There never seems to have been a case on this as such. Thus, exposing sores (Grey, 1864) was more one of public nuisance. The word, anyway, has no clear general, or legal, meaning and it is very subjective. Thus, it would be for a jury to determine, ex post facto, whether an act was 'disgusting' since no member of the public need be present, according to the LC's formulation. Thus, it is asserted this word should be removed;

- $\quad$ Obscene. This should be limited to sexually obscene. Further, it must dovetail with the Sexual Offences Act 2003, s 66 to prevent mis-match and overlap. Surely, nos 1 and 7 should be covered by the latter? And that: (a) public masturbation; (b) public real (or simulated) sex; (c) public intimate filming of a woman (or man), without consent (i.e. nos 2-5) all be expressly provided as examples of 'obscene', to give some clarity as to its meaning? ${ }^{847}$ Further examples could, then, be added as a result of developing caselaw.

In conclusion one would agree with such a new crime, providing it is more restrictive in form than at present.

\section{(d) Corrupting Public Morals (and Conspiring)}

Like public mischief, the courts developed a new crime of corrupting public morals as well as conspiring to do so. In early times, the expression 'contrary to public morals' (contra bonos mores) had no clear legal meaning and was treated, on occasion, as a synonym for public indecency (see App D). ${ }^{848}$ However, in Berg (1927), it was resurrected in uncertain circumstances since there was no publicity or payment (which excluded operating a bawdy house or public indecency). Today, with homosexuality no longer a crime, one would suggest this case would no longer be followed. ${ }^{849}$ Subsequent cases of Shaw v DPP (1962) (publishing a directory of prostitutes) and Knuller $v$ DPP (1973)(gay contact adverts in a magazine) would also not seem to be illegal, given contemporary standards of society. Thus, like public mischief, it is asserted that this crime of corrupting public morals should be abolished.

In conclusion, any statutory crime of public indecency should be limited to acts (or displays) in public which are sexually obscene. It also should be distinct from the Sexual Offences Act 2003, s 26 (intentional display of genitals in public). The crime of corrupting public morals (including conspiring), should be abolished.

\section{CONCLUSION}

The observation of Kenny is relevant:

it is a defect in any system of law that it should be vague and uncertain, especially in its definition of crime. ${ }^{850}$

Today, our criminal law is badly fragmented. It is also virtually unintelligible at times - with so many old common law crimes (many of dubious purport) and huge volume of statutory crimes as well. The purpose of this article has been to assert that there is no need for a statutory (and generic) crime of public nuisance. Not when Parliament sits on a regular basis and 'tailored-made' crimes can be passed, as and when necessary. And, not when it will conflict with statutory crimes in, at least, $95-8 \%$ of cases. In conclusion, the following should be abolished, common law crimes of:

\footnotetext{
${ }^{846}$ LC 358, n 9, para 4.9.

${ }^{847}$ i.e. 'And for the purposes of this section 'obscene' shall include the following....'

${ }^{848}$ See especially the dictum of Mansfield CJ in Jones $v$ Randall (1774) as well as Lynn (1788) and Crunden (1809) and fns. See App D.

${ }^{849}$ Today, the acts of Berg and his companions would appear to be categorised as holding (or seeking to hold) a 'swinging party' in private premises. Absent payment, noise etc, this would not seem to be illegal as such.

${ }^{850}$ Kenny, n 55, p 422.
} 
- Public mischief;

- A common innkeeper refusing a traveller board and lodging;

- Keeping a disorderly (bawdy) house;

- Public nuisance;

Also:

- $\quad$ Corrupting public morals.

- The 1839 and 1847 Acts should be modernised and become part of general legislation (where not obsolete);

- Common law crimes in respect of the unlawful treatment of the dead should become statutory (and placed in burial legislation);

- Consideration should be given to the A-G (as well relevant Government departments) being given a statutory power to prosecute, civilly, for any public nuisance. As happened with criminal libel, de-criminalising such an act will save money for the State as well as likely achieve a better outcome - since damages will be more efficacious than seeking imprisonment (a very unlikely outcome) or a modest fine;

- Public indecency should limited to sexual obscenity and dovetailed with the Sexual Offences Act 2003, s 66;

- It should be a statutory crime to spit, urinate or defecate in public (without reasonable excuse). And, an aggravated crime if the same is on a public building (including a war memorial). 


\section{APP A: CITY ORDINANCE OF 1277-8 ${ }^{85}$}

These are the Assizes of the City of London read by the mayor and reputable men, the second year of the mayoralty of Gregory [de Rokesle], Robert de Arraz and Ralph le Fevere being sheriffs [AD 1276-7], and the third year of the same mayoralty, Walter le Cornewaleys and John, son of John Adrian, sheriffs [AD 1277-8]

1. Peace. First, that the peace of the lord the king be well kept between Christians [and Jews].

2. Bread. Also that two loaves be made for 1d and four loaves for 1d, and that none be coated with bran (furratus) or made of bran. And that no baker sell his bread before his oven, but in the market of the lord the king, and if he be found selling it in his own house he shall be in the mercy of the sheriff; nor shall any one [so] buy, under pain of losing the said bread if it be found; and that no one make bread beyond the assize. Also every baker shall have his seal on his bread, as well brown bread (bissus) as white, that it may the better be known whose the bread is. Also that each Alderman shall view the seals in the ward (custodia). Also that no baker of white bread make tourte bread (turtum)[bread of unbolted meal], nor maker of tourte bread (turturarius) make white bread, for sale under the same penalty, nor any baker buy corn to sell again.

3. Ale. A gallon of ale [to be sold] for three farthings, and [another] for one penny and no dearer. And that no brewster (bracerissa) henceforth sell except by true measures, viz., the gallon, the pottle, and the quart. And that they be marked with the seal of the Alderman, and that the tun be of 150 gallons and sealed by the Alderman.

4. Guests. Also that no one take another in his house for more than one night, unless he hold him to right if he make default, and his host answer for him if he departs. Also that no one shall remain in the ward of an Alderman beyond a day and night, unless he be in frankpledge [or] his host be willing to hold him to right.

5. Street Cleaning \& Pigs. Also that places and lanes shall be cleared of every impediment, as dung, logs, ladders (scalar), pigs (porther) etc under heavy penalty. Also that no pig be henceforth found by the streets or lanes of the City or suburb, nor in the ditches of the City; and if found they shall be killed by whoever finds them, and the killer shall have them without challenge or redemption for 4 pence from the owner. ${ }^{852}$ Whoever wishes to feed his pigs, let him feed them in the open (in franco) away from the king's highway [or] in his house, under heavy penalty.

6. Buying Food. Also that no retail dealer of corn, fish, poultry, or victuals shall buy victuals before the hour of Prime [which commenced at sunrise], nor before the reputable men of the City have bought, under penalty of forfeiting the goods bought.

7. $\underline{\text { Carts. }}$ Also that no cart serving the City by bringing water, wood, stones, etc, be shod with iron (ferrata).

8. Gutters etc. Also that no prentices, gutters, or jetties be of such a height (adeo alta) as to prevent persons riding under them without impediment and hurt, and that they be of the height of nine feet at least.

9. Regratting. Also that no regratress go beyond London Bridge to buy bread and to carry it into the City, because the bakers of the Southwark are not of the Justice of the City nor are allowed to be brought back from (reduci) outside the City.

10. Stalls. And that no stall be of any other breadth than $21 / 2$ feet, and that it be movable or adjustable to the height of its neighbours.

11. Meat. And that no foreign butcher sell meat in the City except in the manner accustomed, nor cause meat to be haboured or permit it to be again carried out of the City; nor buy meat from the Jews to sell again to Christians, or meat slaughtered for Jews and by them rejected.

12. Walbrook River \& King's Highway. And the course of the Walebroke and all the king's road shall be freed....

13. Corn. And that a porter of corn shall not sell nor measure corn, nor presume to enter a churchyard, house, or ship to remove corn, nor lay his hand upon corn, until he be called by those who have bought the corn.

14. Carters. Also that no carman shall for the future enter the City with wood or charcoal for sale, but shall remain outside the gate at Smethefeud [Smithfield] or elsewhere as provided, except only at Cornhull [Cornhill], under forfeiture.

15. Cloth. And that no one cause cloth to be woven [for sale] except in the City, or in Portsoken, or within the franchise of the City, and not in Suthwerk [Southwick][under pain of forfeiture]. And that no woollen cloth be dyed black except in woad [under pain of forfeiture].

16. Market. Also that no market be held on London Bridge, nor elsewhere except in the places appointed.

17. Southwerk [Southwick]. Also that no one of the City go to Suthwerk to buy corn, cattle, or other merchandise there, so as to create a market there, under penalty of forfeiture of the thing bought.

18. Streets from Thames to Tower of London. Also, that all the lanes leading from the Thames from the highway from Castle Baynard as far as the Tower be forthwith cleaned, so that horsemen and footmen may approach the Thames freely and without hindrance; otherwise the sheriffs shall do it at their expense (sumptibus eorum), and still they shall be heavily amerced.

19. Lime. Also that lime be measured by the basket which holds half a quarter, well burnt and honestly measured.

${ }^{851}$ See Letterbook $A$, n 66, pp 215-9. Headings have been added for ease of reference.

${ }^{852}$ See also Letterbook A, n 66, p 220 which contains an ordinance of (likely) similar date 'Moreover that no pig nor rubbish (trunk) nor timber lying be henceforth found in streets, and after Monday [the pig so found] to be killed and become the property of him who shall kill it for 4 pence; the rubbish and the timber forfeited to the use of the sheriffs; hay also and bran henceforth found in Westchepe [i.e. Cheapside]...' 
20. Tiles. And that tiles be well burnt and well leaded, and of ancient pattern (de veteri scantilone).

21. Merchants. Also that no one shall carry on merchandise in the City, nor make bread nor ale for sale, unless he be willing to be of the Justice of the City. Also that no broker presume to lead merchant strangers out of the City to deal with them, nor buy any merchandise for his own use, nor harbour any strangers, nor shall any stranger harbour other merchant strangers. No merchant who brings woad [a blue dye] to London shall measure it, but only he who is sworn for the purpose, and by the quarter (per quarterium) of the City assigned for the purpose.

22. Lepers. No leper shall be in the City, nor come there, nor make any stay there.

23. Jews. No one shall hire houses from Jews, nor demise the same to them to live in outside the limits of the Jewry.

24. Fish sellers. Also vendors of fish shall not throw their water into the highway, but cause it to be carried to the Thames.

25. Rubbish in the Highway. Also no one shall throw any filth in the highway, nor allow it to be raked in the time of rain, nor remove it so as to be a nuisance to the neighbours.

26. Measures. Also that no one shall have a measure, beam, or other weight, unless it be good and just and agreeing with the king's beam and weights. 


\section{APP B: TOWN POLICE CLAUSES ACT 1847}

\section{The Act, s 28 provides: (sections extant are underlined and headings added for ease of reference).}

Every person who in any street, to the obstruction, annoyance, or danger of the residents or passengers, commits any of the following offences, shall be liable to a penalty [etc]

\section{$\underline{\text { Animals }}$}

Every person who exposes for show, hire, or sale (except in a market or market place or fair lawfully appointed for that purpose) any horse or other animal, or exhibits in a caravan or otherwise any show or public entertainment, or shoes, bleeds, or farries any horse or animal (except in cases of accident), or cleans, dresses, exercises, trains, or breaks, or turns lose any horse or animal, or makes or repairs any part of any cart or carriage (except in cases of accident where repair on the spot is necessary);

Every person who suffers to be at large any unmuzzled ferocious dog, or sets on or urges any dog or other animal to attack, worry, or put in fear any person or animal;

Every owner of any dog who suffers such dog to go at large, knowing or having reasonable ground for believing it to be in a rabid state, or to have been bitten by any dog or other animal in a rabid state;

Every person, who after public notice given by any Justice directing dogs to be confined on account of suspicion of canine madness, suffers any dog to be at large during the time specified in such notice;

Every person who slaughters or dresses any cattle, or any part thereof, except in the case of any cattle overdriven which may have met with any accident, and which for the public safety or other reasonable cause ought to be killed on the spot;

\section{Waggons, Carts}

Every person having the care of any waggon, cart or carriage who rides on the shafts thereof, or who without having reins, and holding the same, rides upon such waggon, cart, or carriage, or on any animal drawing the same, or who is at such a distance from such waggon, cart, or carriage as not to have due control over every animal drawing the same, or who does not, in meeting any other carriage, keep his waggon, cart, or carriage to the left or near side, or who in passing any other carriage does not keep his waggon, cart, or carriage on the right or off side of the road (except in cases of actual necessity, or some sufficient reason for deviation), or who, by obstructing the street, wilfully prevents any person or carriage from passing him, or any waggon, cart, or carriage under his care;

Every person who at one time drives more than two carts or waggons, and every person driving two carts or waggons who has not the halter of the horse in the last cart or waggon securely fastened to the neck of the first cart or waggon, or has such halter of a greater length from such fastening to the horse's head than four feet;

Every person who rides or drives furiously any horse or carriage, or drives furiously any cattle;

Every person who causes any public carriage, sledge, truck, or barrow, with or without horses, or any beast of burden, to stand longer than is necessary for loading or unloading goods, or for taking up or setting down passengers (except hackney carriages, and horses and other beasts of draught or burthen, standing for hire in any place appointed for that purpose by the Commissioners or other lawful authority), and every person who, by means of any cart, carriage, sledge, truck, or barrow, or any animal, or other means, wilfully interrupts any public crossing, or wilfully causes any obstruction in any public footpath or other public thoroughfare;

Every person who causes any tree, or timber, or iron beam, to be drawn in or upon any carriage, without having sufficient means of safely guiding the same;

Every person who leads or rides any horse or other animal, or draws or drives any cart or carriage, sledge, truck, or barrow, upon any footway of any street, or fastens any horse or other animal so that it stands across or upon any footway;

\section{Obstructing Footwavs, Streets}

Every person who places or leaves any furniture, goods, wares, or merchandise, or any cask, tub, basket, pail or bucket, or places or uses any standing place, stool, bench, stall, or show board on any footway, or who places any blind, shade, covering, awning, or other projection over or along any such footway, unless such blind, shade, covering, awning, or other projection, is eight feet in height at least in every part thereof from the ground;

Every person who places, hangs up, or otherwise exposes to sale any goods, wares, merchandise, matter or thing whatsoever, so that the same project into or over any footway, or beyond the line of any house, shop, or building, at which the same are so exposed so as to obstruct or incommode the passage of any person over or along such footway;

Every person who rolls or carries any cask, tub, hoop, or wheel, or any ladder, plank, pole, timber, or log of wood, upon any footway, except for the purpose of loading or unloading any cart or carriage, or of crossing the footway;

Every person who places any line, cord, or pole across any street, or hangs or places any clothes thereon;

\section{$\underline{\text { Indecency }}$}

Every common prostitute or nightwalker loitering and importuning passengers for the purpose of prostitution; 
Every person who wilfully and indecently exposes his person;

Every person who publicly offers for sale or distribution or exhibits to public view, any profane, indecent, or obscene book, paper, print, drawing, painting, or representation, or sings any profane or obscene song or ballard, or uses any profane or obscene language;

\section{Fireworks}

Every person who wantonly discharges any firearm, or throws or discharges any stone or other missile, or makes any bonfire, or throws or sets fire to any firework;

$\underline{\text { Noise }}$

Every person who wilfully and wantonly disturbs any inhabitant, by pulling or ringing any door-bell, or knocking at any door, or who wilfully and unlawfully extinguishes the light of any lamp;

\section{$\underline{\text { Kites \& Slides }}$}

Every person who flies any kite, or who makes or uses any slide upon ice or snow;

\section{Cleaning Tubs}

Every person who cleanses, hoops, fires, washes, or scalds any cask or tub, or hews, saws, bores, or cuts any timber or stone, or slacks, sifts, or screens any lime;

\section{Throwing Down Things}

Every person who throws or lays down any stones, coals, slate, shells, lime, bricks, timber, iron, or other materials (except building materials so enclosed as to prevent mischief to passengers);

\section{Shaking Mats}

Every person who beats or shakes any carpet, rug, or mat (except door mats, beaten or shaken before the hour of eight in the morning);

\section{$\underline{\text { Flowerpots }}$}

Every person who fixes or places any flower pot or box, or other heavy article, in any upper window, without sufficiently guarding the same against being blown down;

\section{Throwing From Roof}

Every person who throws from the roof or any part of any house or other building any slate, brick, wood, rubbish, or other thing, except snow thrown so as not to fall on any passenger);

\section{Standing on Sills or Windows}

Every occupier of any house or other building or other person who orders or permits any person in his service to stand on the sill of any window, in order to clean, paint, or perform any other operation upon the outside of such window, or upon any house or other building within the said limits, unless such window be in the sunk or basement story;

\section{Leaving Open Vaults \& Cellars}

Every person who leaves open any vault or cellar, or in the entrance from any street to any cellar or room underground, without a sufficient fence or handrail, or leaves defective the door, window, or other covering of any vault or cellar, or does not sufficiently fence any area, pit or sewer left open, or who leaves such open area, pit or sewer, without a sufficient light after sunset to warn and prevent persons from falling there into;

\section{$\underline{\text { Rubbish \& Night Soil }}$}

Every person who throws or lays dirt, litter, or ashes, or nightsoil, or any carrion, fish, offal, or rubbish, on any street, or causes any offensive matter to run from any manufactory, brewery, slaughter-house, butcher's shop, or dunghill, into any street: Provided always, that it shall not be deemed an offence to lay sand or other materials in any street in time of frost, to prevent accidents, or litter or other suitable materials to prevent the freezing of water in pipes, or in case of sickness to prevent noise, if the party laying any such things seek them to be removed as soon as the occasion for them ceases;

Pigsty

Every person who keeps a pigsty to the front of any street, not being shut out from such street by a sufficient wall or fence, or who keeps any swine in or near any street, so as to be a common nuisance.

Other matters in the Act which related to public nuisances comprised:

$\underline{\text { Riotous or Indecent Behaviour (s 29) }}$ 
Every person drunk in any street, and guilty of any riotous or indecent behaviour therein, and also every person guilty of any violent or indecent behaviour in any police office or any police station within the limits of the special Act shall be liable to penalty.

\section{Chimney (ss $30 \& 31)$}

[Penalty for setting chimneys wilfully on fire. Also, for accidentally allowing chimneys to catch fire].

\section{Disorderly Persons (s 35)}

Every person keeping any house, shop, room, or other place of public resort within the limits of the special Act for the sale or consumption of refreshments of any kind, who knowingly suffers common prostitutes or reputed thieves to assemble at and continue in his premises shall [be liable to a penalty]

\section{Bear Baiting \& Cock Fighting (s 36)}

[Penalty on persons keeping places for bear baiting, cock fighting or worrying other animals].

\section{Public Bathing (s 69)}

Where any part of the sea-shore or strand of any river used as a public bathing place is within the limits of the special Act, the Commissioners may make bye-laws for the following purposes....For preventing any indecent exposure of the persons of the bathers...

CONCLUSION: The underlined (extant) sections should be placed in general legislation (if required). The same applies to similar sections in the 1839 Act. Remaining material in the 1847 Act relates to street obstructions (s 21), stage carriages (s 23) and hackney carriages. It should be placed in Highways legislation (excising obsolete material). 


\section{APP C: PUBLIC NUISANCE- CASELAW}

Cases in italics are civil cases or cases where public nuisance was not upheld.

Hall

Herring v Walrond

Webb

Arnold v Jefferson

Rosewell

Watts

Pappineau

Smith

Anon

White v Ward

Anon

Higgins

Lloyd

$1671^{853}$ Rope dancer obstructing the highway. [Now governed by highway legislation].

$1682^{854}$ Display of a monstrous child (Siamese twins, dead and embalmed), for show for money. The Lord Chancellor ordered the child to be buried. [This is better governed by the law on the unlawful treatment of the dead].

$1697^{855}$ To extend a house whereby the street becomes darker, not a public nuisance.

$1697^{856} \quad$ Stopping lights is a nuisance. Stopping a prospect is not.

$1698^{857}$ If one builds a house so near to another it stops the light (or shoots water on the house), I may enter the owner's land and pull it down.

$1703^{858}$ Indictment for letting a house on the highway to be likely to fall down lies against the tenant at will. [Now governed by legislation].

$1725^{859}$ Indictment for nuisance (steeping stinking skins in water) laying it to be committed near the highway and also near several dwelling houses etc. is sufficient. Judgment affirmed. [Now governed by legislation].

$1725^{860}$ Nuisance to make great noises in the night with a speaking trumpet, to the disturbance of the neighbourhood. [Now governed by noise legislation].

$1752^{861}$ Injunction refused to stop building of house to inoculate for smallpox. [Now governed by health legislation].

$1757^{862}$ Noisome and offensive stinks and smells (factory making acid spirit of sulphur, oil of vitriol and oil of aqua fortis) to those passing the highway in Twickenham, London. Each D (on undertaking to avoid repetition) was fined. [Now governed by legislation].

$1770^{863}$ Conviction of featherbed-maker for beating feathers in the street. [Now covered by legislation]

$1801^{864}$ Lawrence $\mathrm{J}$ 'all offences of a public nature, that is, all such acts or attempts as tend to the prejudice of the community, are indictable.' Obiter.

$1802^{865}$ Indictment for nuisance (noise) brought by certain attornies of Clifford's Inn against a tinner. Held a private nuisance, if anything.

853 (1671) 1 Vent 169 (86 ER 115). See also McBain, n 90, p 33, n 158.

854 (1682) 2 Cha Cas 110 (22 ER 412). Herring was also spelt Harring.

855 (1697) 1 Ld Raym 737 (91 ER 1393). For an older case in 1333 on this point, see 7 Edw III pl 25, fo 50b, Seipp no 1333.150.

${ }^{856}$ (1697) 3 Salk 248 (91 ER 804). See also, re a prospect, Aldred's Case (1611), n 516. Also, Fifoot, n 150, p 101.

${ }^{857}$ (1695) 2 Salk 459 (91 ER 397). See also Dalton, n 373.

${ }^{858}$ (1703) 1 Salk 357 (91 ER 31). Per Curia 'the house was a nuisance as it stood, and the continuing the house in that condition is continuing the nuisance....the danger is the matter that concerns the public.' See also Watson (1703) 2 Ld Raym 856 (92 ER 72 ). For older cases of ruinous walls and houses in London dealt with by an assize of nuisance (even when it affected the commonality) see Chew, $\mathrm{n} 152$, $\mathrm{p}$ xxviii.

${ }^{859}$ (1725) 2 Stra 686 (93 ER 784).

${ }^{860}$ (1725) 2 Stra 703 (93 ER 795 ).

${ }^{861}$ (1752) 3 Atk 750 (26 ER 1230) per Lord Hardwicke at p 75 'the fears of mankind, though they may be reasonable ones, will not create a nuisance.'

862 (1757) 1 Burr 333 (97 ER 338). See also Oldham, n 526, vol 2, pp 886, for this case and others. White was cited in Rimmington [2006] 1 AC 459 at $\mathrm{p} 471$. For older cases in which trade matters were dealt with in London by means of an assize of nuisance see Chew, $\mathrm{n} 152$, $\mathrm{p}$ xxxi 'a chalk-pit for tanning hides; dyers' workmen who carried their dripping cloths up and down steps allegedly belonging to a neighbour; a tenter-yard; tenting-frames which damaged a wall; the work-shop of Queen Philippa's tailor; a scalding house...in which pigs and other animals were slaughtered; forges built in the public highway...the forge of an armourer whose sledgehammers shook the neighbours' walls, disturbed their rest and soiled their wine and ale, while the stench and smoke from the sea-coal used in his forge penetrated their hall and chambers.' See generally, JPS McLaren, Nuisance Law and the Industrial Revolution - Some Lessons in Social History (1983) 3 OJLS 155221. Also, WR Cornish \& G de N Clark, Law and Society in England 1750-1950 (Sweet \& Maxwell, 1989), pp 154-66.

${ }^{863}$ Annual Register 1770, p 74, cited by Baker, n 20, p 434.

${ }^{864}$ (1801) 2 East 5 (102 ER 269) at p 275 (the case held that, to solicit (incite) a servant to steal his master's goods, was a misdemeanour).

${ }^{865}$ (1802) 4 Esp 200 (170 ER 691) per Lord Ellenborough 'it was, if anything, a private nuisance. It was confined to the inhabitants of three numbers [houses] of Clifford's Inn only.' 
Jones

$1812^{866}$

Cross

$1812^{867}$

Dixon

Vantandillo

Moore

Medley

Carlile

Wilkes v Hungerford Market

Barnes v Ward

Soltau v De Held

Garland

Henson
Indictable offence for timber merchant to cut logs in the street adjoining his yard. [Now governed by highway legislation. Was also a City offence, see App A, no 5].

Indictable offence for stage coaches to stand plying for trade in the public streets. [Now governed by highway legislation].

$1814^{868}$ Sale of bread by baker with contaminant (alum). Unfit for human consumption. [Now governed by food legislation. In the past, usually taken as an example of cheat].

$1815^{869}$ Taking a child with smallpox along a public highway. [Now governed by health legislation].

$1832^{870}$ Operated a rifle range in Bayswater where customers shot pigeons. It caused a crowd to assemble, causing noise, damage, disturbance and mischief. On conviction D undertook to discontinue shooting. No penalty imposed. [Now governed by highway, noise and firearms legislation].

$1834^{871}$ Pollution of river Thames with gas, rendering it unfit to drink. Directors each fined. [Now governed by water legislation].

$1834^{872}$ Displayed in a printer's shop an effigy of a bishop in arm with the devil. [Unlikely to be prosecuted todayl.

$1835^{873} \quad P$ (a bookseller) had a shop by the side of a public thoroughfare. Suffered loss due to passers being diverted from the thoroughfare as a result of D continuing across it an authorised obstruction, but for an unreasonable time..

$1850^{874}$ Excavation to public footway not fenced leading to death of passer-by. Maule J 'newly-made excavation adjoining an immemorial public way, which rendered the way unsafe to those who used it with ordinary care...the [D] in having made that excavation, was guilty of a public nuisance.' [Now governed by highway legislation].

$1851^{875}$ Injunction granted to restrain the ringing of Catholic church bells to the annoyance of $P$ who resided nearby. A bill may be filed to restrain a public nuisance without making the $A-G$ a party, if the P suffers special damage.

$1851^{876}$ Manufactured arsenic which poisoned cattle in neighbouring fields by particle vapour. [Now governed by legislation].

$1852^{877}$ D brought mare with contagious disease (glanders) into a public place (a fair). [Now governed by animal legislation]

${ }^{866}$ (1812) 3 Camp 230 (170 ER 1364) per Lord Ellenborough at p 230 'If an unreasonable time is occupied in the operation of delivering beer from a brewer's dray into the cellar of a publican, this is certainly a nuisance. A cart or waggon may be unloaded at a gateway; but this must be done with promptness. So as to the repairing of a house; - the public must submit to the inconvenience occasioned necessarily in repairing the house; but if this inconvenience is prolonged for an unreasonable time, the public have a right to complain and the party can be indicted for a nuisance.'

${ }^{867}$ (1812) 3 Camp 224 (170 ER 1362) per Lord Ellenborough at p 227 'A stage-coach may set down or take up passengers in the street, this being necessary for the public convenience; but it must be done in a reasonable time.'

${ }^{868}$ (105 ER 516). See also Spencer, n 3, p 62. Bacon, n 39 (7th ed (last ed), 1832) treated it as a common nuisance. For indictments on cheat see Tremaine (in 1723), n 355, index (indictments for cheats, deceits).

${ }^{869}$ (1815) 4 M \& S 73 (105 ER 762) per Le Blanc J at p 76 'there could be no doubt in point of law that, if a person unlawfully, injuriously, and will full knowledge of the fact, exposes in a public highway a person infected with a contagious disorder, it is a common nuisance to all the subjects, and indictable as such.' Cited in Rimmington [2006] 1 AC 459 at p 471. Cf. Coke, n 43, vol 3, p 90 'If any person infected with the plague, commanded (by such persons as are appointed by the Act) to keep house, shall contrary to such commandment wilfully and contemptuously go abroad, and shall converse in company, having any infectious sore upon him uncured, such person shall be adjudged a felon. Coke referred to 1 Jac 31 (1603, rep 1837).

${ }^{870}$ (1832) 3 B \& Ad 184 (110 ER 68) per Tenterden CJ at p 188 'If a person collects together a crowd of people to the annoyance of his neighbours, that is a nuisance for which he is answerable.' Cited in Rimmington [2006] 1 AC 459 at p 471.

${ }^{871}$ (1834) 6 C \& P 292 (172 ER 292). Cited in Rimmington [2006] 1 AC 459 at p 471.

${ }^{872}$ (1834) 6 C \& P 628 (172 ER 1397).

873 (1835) 2 Bing NC 281 (132 ER 110).

${ }^{874}$ (1850) 9 CB 392 (137 ER 945), per Maule J at p 956.

875 (1851) 2 Sim NS 133 (61 ER 291) per Kindersley VC at p 142 ' to constitute a public nuisance, the thing must be such as, in its nature or its consequences, is a nuisance - an injury or a damage, to all persons who come within the sphere of its operation, though it may be so in a greater degree to some than it is to others.' Cited in Rimmington [2006] 1 AC 459 at p 471.

${ }^{876}$ (1851) 5 Cox CC 165.

${ }^{877}$ (1852) 1 Dears CC 24 (169 ER 621). Cited in Rimmington [2006] 1 AC 459 at p 471. 
Lister

Crawley

Stevenson

Jarvis

Mutters

Grey

Stephens

Shillito v Thompson

Price

Barber v Penley

A-G v Tod Heatley

Meade

Dwyer v Mansfield
$1856^{878}$

Keeping explosives or other flammable articles (in London) in circumstances which cause public danger or to persons in their homes or on the highway is a public nuisance. [Now governed by legislation on explosives].

$1862^{879}$ Person not indictable for sending meat to a meat salesman he knows to be unfit for human consumption if he does not know it is so intended to be used. [Now governed by food legislation. ${ }^{880}$ In any case, it was governed by Assize of the Pillory c. $1266\left(\right.$ rep 1866) ${ }^{881}$ and the common law crime of cheat, now abolished].

$1862^{882}$ A meat salesman can be convicted at common law for knowingly sending and exposing meat for sale in a public market as fit for human consumption, when not. [Same as Crawley]

$1862^{883}$ A carrier can be convicted at common law for knowingly bringing to market meat unfit for human consumption when it was not. [Same as Crawley]

$1864^{884}$ Explosion at quarry scattered rock to a neighbouring house and the highway and that D allowed stones to remain on the highway for several hours. [Now governed by legislation].

$1864^{885}$ Herbalist exhibited a picture of a man with sores in his shop window. Guilty of nuisance although nothing immoral or indecent in the picture and his motive was innocent.

$1866^{886}$ Owner of slate quarry. Public nuisance when his employees tipped slag into a river, even though he had told them not to. [Now governed by legislation].

$1875^{887}$ Byelaw $r e$ the exposure, or offering for sale, of unwholesome food. [Now governed by food legislation].

$1884^{888}$ Burning a dead body on highway (or other public place) is a public nuisance [Better treated as an offence relating to the unlawful treatment of the dead]

$1893^{889}$ Lessee of theatre liable for obstruction to the highway by reason of a crowd gathering prior to the doors opening. [Now governed by highway legislation].

$1897^{890}$ Allowed land to be used as a rubbish dump, creating a dangerous, or noxious, environment. [Now governed by legislation].

1903 Discharged revolver at bedroom window of house. Charged at Carnarvon Assizes under an Act of 1328 (2 Edw 3 c 3 rep 1967) and with public nuisance. Convicted under 1328 Act. Position as to public nuisance not indicated. ${ }^{891}$ [Now governed by firearms and noise legislation].

$1946^{892}$ Queues formed outside D's shop since he was only selling 1 lb of potatoes per ration book due to wartime scarcity. Held obstruction of the pavement was not unreasonable. The nuisance

\footnotetext{
878 (1856) Dears \& Bell 209 (169 ER 979).
}

${ }^{879}$ (1862) 3 F \& F 109 (176 ER 49). Cited in Rimmington [2006] 1 AC 459 at pp 471-2 'It is not entirely clear that these offences [he cited Crawley and Jarvis as well] were charged as common nuisances at common law.'

${ }^{880}$ See Food Safety Act 1990, s 14(1) 'Any person who sells to the purchaser's prejudice any food which is not of the nature or substance or quality demanded by the purchaser shall be guilty of an offence. (2) In [ss 1] the reference to sale shall be construed as a reference to sale for human consumption...' See also s 15 (falsely describing or presenting food). s 16 of this Act also makes provision for food safety regulations. See Archbold Procedure, n 62, paras 20-68 to 87.

${ }^{881}$ See also Edw 1. De Pistoribus et Braciatoribus et aliis Vitellariis [Of Bakers, Brewers and other Victuallers](date uncertain). See also Broomhead (1844) Jurist, vol 7, pt 1, p 559 in which case such matters are discussed. See also Powell (in 1668), n 134, p 107.

882 (1862) 3 F \& F 106 (176 ER 48). Cited in Rimmington [2006] 1 AC 459 at p 472

${ }^{883}$ (1862) 3 F \& F 108 (176 ER 49). Cited in Rimmington [2006] 1 AC 459 at p 472

${ }^{884}$ (1864) Le \& Ca 491 (169 ER 1485).

${ }^{885}$ (1864) 4 F \& F 73 (176 ER 472) per Willes J at p 75 'There is no doubt the exhibition of the picture on a highway is a nuisance. It is so disgusting that it is calculated to turn the stomach. No man has the right to expose disgusting and offensive exhibitions in or upon a public highway. The object may be innocent or laudable, and there is nothing indecent or immoral in the exhibition.'

${ }^{886}$ (1866) LR 1 QB 70. Cited in Rimmington [2006] 1 AC 459 at p 472.

${ }^{887}$ (1875) 1 QBD 12.

${ }^{888}$ (1884) 12 QBD 247 per Stephen J at p 256 'To burn a dead body in such a place and such a manner as to annoy persons passing along public roads or other places where they have a right to go is beyond all doubt a nuisance, as nothing more offensive both to sight and smell can be imagined.' Cf. $R$ (Ghai) v Newcastle CC [2010] EWCA Civ 59. See generally, McBain, n 19, p 91.

${ }^{889}$ [1893] 2 Ch 447.

${ }^{890}$ [1897] 1 Ch 560 .

${ }^{891}$ ES Fay, Discoveries in the Statute-Book (1939), p 156.

${ }^{892}$ [1946] KB 437. Cf. Fabbri v Morris [1947] 1 AE 315(D sold ice cream through shop window, causing crowd to gather. Convicted under the Highways Act 1835, s 72). 
Southport Corpn v Esso

$A-G \nu P Y A$ Quarries

Clark (No 2)

Adler

Moule

Wheeler

Dymond v Pearce

Madden

Norbury

Soul

Tysoe v Davies

Holme

Sykes $v$ Holmes

$1985^{905}$ Accused sniffed glue in a school playground when staff and pupils were absent. Held to be a
nuisance within the Local Government (Miscellaneous Provisions) Act 1982, s 40. Whether it would be a public nuisance would depend on the public nature of the nuisance. $S 40$ was repealed by Education Act 2002, sch 22(3), para 1.

Millward

was created by the scarcity of potatoes and D was carrying on his business in a normal and proper way. [Now governed by highway legislation].

Civil Case. Denning LJ 'it is... a public nuisance to discharge oil into the sea in such circumstances that it is likely to be carried on to the shores and beaches of our land to the prejudice and discomfort of Her Majesty's subjects.' . [Now governed by legislation].

$1957^{894}$ Civil case. Blasting and quarrying near built up areas. Action brought by A-G on the behalf of two county councils. [Now governed by legislation].

$1964^{895} \quad$ Inciting a person to commit a public nuisance by obstructing the highway in and around Whitehall. Conviction quashed. Issue of reasonableness not presented to the jury. INow governed by highway legislation].

$1964^{896}$ Incitement to commit a public nuisance by obstructing the highway. Only an obstruction caused by unlawful user of the highway is a public nuisance. [Now governed by highway legislation].

$1964^{897}$ To sit down on a highway was an unreasonable obstruction. Convicted of inciting others to cause (and himself to cause) an obstruction of the highway. [Now governed by highway legislation].

$1971^{898}$ Kept a puma and leopards in a domestic garden. [Now governed by animal legislation]

$1972^{899}$ Obstruction of highway by parking a large vehicle on it for many hours. [Now governed by highway legislation].

$1975^{900}$ Hoax bomb phone call, causing danger and discomfort to 8 security officers. Held not to be a public nuisance. [Now governed by legislation].

$1978^{901} \quad$ Hundreds of obscene phone calls to women. Making an obscene call was a summary offence under the Post Office Act 1969, s 78 (maximum penalty £50). [Rimmington held that wrongly decided].

$1980^{902}$ Appellant agreed with others to secure the release of a restricted Broadmoor patient. Convicted of conspiring to effect a public nuisance. [Now governed by legislation - Mental Health Act 1983].

$1983^{903}$ Horsebox driven with smoke pouring from the back causing accident. Held public nuisance since: (1) smoke rendered highway less commodious to other road users; (2) created a dangerous obstruction; (3) D's had acted unreasonably. [Now governed by highway legislation].

$1984^{904}$ Case summarised by Spencer, n 3, p 78 'an eccentric who upset his neighbours by a catalogue of bizarre behaviour which included playing one chord on his piano all night, playing a radio at top volume whilst it was suspended out of his bedroom window on a rope, and 'behaving in an intimidating manner on the public highway, imitating an ape.' [Now governed by noise and anti-social legislation]

Hundreds of phone calls to a police woman, likely to disrupt the station switchboard. [Now

893 [1954] 2 QB 182 at 197 per Denning LJ reversed [1956] AC 218. Cited in Rimmington [2006] 1 AC 459 at p 472.

${ }^{894}$ [1957] 2 QB 169. Per Romer LJ at p 184 'any nuisance is 'public' which materially affects the reasonable comfort and convenience of life of a class of Her Majesty's subjects'. Cited in Rimmington [2006] 1 AC 459 at p 473.

895 [1964] 2 QB 315.

${ }^{896}$ [1964] Crim LR 304.

${ }^{897}$ [1964] Crim LR 303.

${ }^{898}$ The Times, 17th December. See also Burn, n 11 (last ed (30th ed) 1869), p 1032) 'Keeping ferocious animals without proper control is a public nuisance...'

${ }^{899}$ [1972] 1 AE 1142.

${ }^{900}$ [1975] 1 WLR 1379. Cited in Rimmington [2006] 1 AC 459 at p 474

${ }^{901}$ [1978] Crim LR 435. Cited in Rimmington [2006] 1 AC 459 at p 476.

902 (1980) 70 Cr App R 295. Cited in Rimmington [2006] 1 AC 459 at p 477. See also [1980] Crim LR 234

${ }^{903}$ [1983] Crim LR 684.

9041984 CLY No 2471.

905 [1985] Crim LR 791.

${ }^{906}$ (1986) 8 Cr App R (S) 209. Cited in Rimmington [2006] 1 AC 459 at pp 476-7. 
Ruffell

Shorrock

Johnson (Anthony)

Ong

Nottingham CC v Zain

Eskdale

Harley

Holliday \& Leboutillier

Lowie

Rimmington

Goldstein

Bourgass

[Anon]

DPP v Fearon

Dallinger

McGuire

\section{governed by legislation].}

$1991^{907}$ Acid house party - very loud music, nearby roads blocked with traffic, surrounding woodland littered with excrement. [Now governed by noise, highway and rave legislation].

1994908 Accused allowed a rave to take place in his field. [Now governed by rave legislation].

$1997^{909}$ Hundreds of obscene phone calls. [Rimmington held that wrongly decided].

$2001^{910}$ D convicted of conspiracy to commit a public nuisance by seeking to switch off the lights at a Premiership football match.

$2001^{911}$ Gang activity involving drug dealing in urban area (for grant of injunction). [Drug dealing is a crime and the issue related to the power of local authority to prevent a public nuisance on the highway]. ${ }^{912}$

$2002^{913} 1000$ obscene phone calls. [Now governed by legislation].

$2003^{914} 5000$ obscene phone calls. [Now governed by legislation].

$2005^{915}$ Appellants were animal liberation activists. Made phone calls designed to jam the switchboards of various companies. Some calls were threatening and intimidating. [Now governed by legislation].

$2005^{916}$ Hoax calls to the emergency services. [Now governed by legislation]

$2006^{917}$ Campaign of racist hate mail sent to members of ethnic minorities. Held that, being a series of acts directed at individuals rather than the public at large, it fell outside the scope of the offence of public nuisance.

2006 Sent salt in post as a joke. It leaked and caused an anthrax scare at sorting office. Not guilty. No reason to suppose he knew (or should have known) that salt would leak.

$2007^{918} 17$ years for plotting a ricin attack on the Underground (exceeding maximum under the AntiTerrorism, Crime and Security Act 2001, s 113). ${ }^{919}$ [Now governed by legislation].

$2009^{920}$ Group of men pleaded guilty to conspiracy to commit public nuisance by making videos threatening bombings. [Now governed by legislation].

$2010^{921}$ Approached undercover policewoman on a single occasion and asked for sex. Since single occasion, public nuisance rejected.

$2012^{922}$ Standing on wrong side of the barrier on a motorway bridge.

$2012^{923}$ Substituting a drug in a chemist's shop. [Administering poison or noxious thing with intent to injure or annoy, Offences against the Person Act 1861, s 24]

907 (1991) 13 Cr App R (S) 204. Cited in Rimmington [2006] 1 AC 459 at p 475. See also Blackstone CP, n 61, para B11.85.

908 [1994] QB 279. Cited in Rimmington [2006] 1 AC at p 475.

909 [1997] 1 WLR 367. Cited in Rimmington [2006] 1 AC 459 at p 477.

${ }^{910}$ [2001] 1 Cr App Rep (S) 404. Cited in Rimmington [2006] 1 AC 459 at p 475.

911 [2002] 1 WLR 607.

912 See Highways Act 1980, s 130(1)(5). Also, Local Government Act 1972, s 222(1).

913 [2002] 1 Cr App R (S) 118. Cited in Rimmington [2006] 1 AC 459 at p 477.

914 [2003] 2 Cr App R (S) 16. Cited in Rimmington [2006] 1 AC 459 at p 477.

915 [2005] 1 Cr App R (S) 349. Cited in Rimmington [2006] 1 AC 459 at p 477.

${ }^{916}$ [2005] 1 Cr App R (S) 530. Cited in Rimmington [2006] 1 AC 459 at p 477.

917 [2006] 1 AC 459.

918 [2007] 2 Cr App R (S) 40.

${ }^{919}$ Smith \& Hogan, n 57 (2015), p 1265, n 291 'Bourgass could have been charged under s 58 of the Terrorism Act 2000 if it really was clear that he intended to use the information he had collected in terrorist activities.'

${ }^{920}$ LC 358, n 9, para 2.23.

921 [2010] 2 Cr App R 22.

922 [2013] 1 Cr App R (S) 38.

923 [2012] EWCA Crim 2680 


\section{APP D: PUBLIC INDECENCY- CASELAW}

Included in this list are cases relating to corrupting public morals such as Berg (1927), Dale (1960), Shaw v DPP (1962) and Knuller v DPP (1973). Those marked with a * relate to indecent exposure.

Sedley(Sidley) $\quad 1663^{924}$

Harrison \& Ux v Dr Burrell $1670^{927}$

Ford Lord Grey of Werk $\quad 1682^{928}$

Galizard v Rigault

$1702^{934}$

Peirson

$1706^{935}$
Fined 2000 marks, imprisoned without bail for 1 week and bound over to good behaviour for 1 year for exposing his naked body on a balcony in Covent Garden and hurling down bottles (with urine) on people below. This case is not well reported. Sidley (with two companions), when drunk, appeared naked on the balcony of the Cock Tavern in Bow Street by Covent Garden and preached a mock, blasphemous sermon. The result was a hail of stones from the crowd of, possibly, 1000 persons. Likely, many were puritans. His punishment, therefore, was as much for blasphemy and battery (by hitting others with bottles) as for nudity. ${ }^{925}$ Pepys' version is slightly different and more scandalous. ${ }^{926}$

It was noted that adultery, fornication and the soliciting of the chastity of a person (i.e.seeking sex with a person, virgin or not) had been ecclesiastical offences.

Trial for a misdemeanour in having sex with (debauching) an 18 year old virgin (Lady Henrietta Berkeley, his wife's sister). ${ }^{929}$ Judgment not given. The information in the case ${ }^{930}$ referred to: (a) abduction; ${ }^{931}$ (b) adultery (by Ford) ${ }^{932}$ and (c) fornication. ${ }^{933}$ It is unclear whether any crime had been committed since Berkeley was over 16 (thus, not an heiress under 16) and it was consensual.

To commit adultery was not a crime.

To solicit sex (the chastity of a person) was not a crime.

9241 Sid 568 (82 ER 1036) 'pur several misdemeanors encounter le peace del roy et que fueront al grand scandal de Christianity.' Also, Sydles Case (1663) 1 Keb 620 (83 ER 1146) 'showing himself naked in a balcony, and throwing down bottles (pist in) vi et armis among the people in Convent Garden, contra pacem, and to the scandal of the Government.' See also Curl (1727) 2 Stra 789 (93 ER 849)(obscene publication) and Read (1707) Fort 98 (92 ER 777)(obscene libel), for comments on Sedley. See also Shaw v DPP [1962] AC 220 (references to Sidley). Hawkins, n 10, vol 1, p 7 treated this as an ecclesiastical offence.

${ }^{925}$ The story is well told in V De Sola Pinto, Sir Charles Sedley 1639-1701 (1927), pp 59-67 (Charles I (1649-60) reduced the fine by a half).

${ }^{926}$ R Latham \& W Matthews, The Diary of Samuel Pepys (1971), vol 4 (1663), p 209 (1 July 1663) 'Mr Batten [William Batten, a barrister of Lincoln's Inn] telling us of the late triall of Sir Charles Sydly the other day, before my Lord Chief Justice Foster and the whole bench - for his debauchery a little while at Oxford Kate's [i.e. the Cock Tavern]; coming in open day into the Balcone and showed his nakedness acting all the postures of lust and buggery that could be imagined, and abusing of scripture and, as it were, from thence preaching a Mountebanke sermon from the pulpitt, saying that there he hath to sell such a pouder [powder] as should make all the c...s in town run after him - a thousand people standing underneath to see and hear him. And that being done, he took a glass of wine and washed his p...k in it and then drank it off; and then took another and drank the king's health.' See also Pepys, Diary (ed Wheatley) vol 3, p 122 (1 July 1663).

${ }^{927} 2$ Vent 9(86 ER 278), at pp 10-11. Coke, n 43, vol 2, p 488 noted that, in early times (he cited Domesday Book 1087), the king's courts punished adultery and fornication by the imposition of a fine called leirwite (leatherwite)). This offence was Anglo-Saxon, see McBain, $\mathrm{n} 90$, p 22, ns $59 \& 61$ (at least, for those committing adultery or clerics). However, by Coke's time it seems clear that punishment in the king's

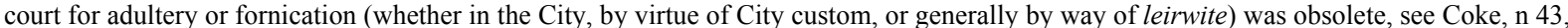
vol 3, p 205 ('But now these offences belong to the ecclesiastical court.'). One wonders whether this was connected with his own daughter, see $\mathrm{n} 932$ (she gave birth to a son out of wedlock in 1624 and was tried for adultery in 1627). Coke died in 1634 (his dislike of the Court of High Commission was notorious).

${ }^{928}$ See (1682) 9 St Tr 127. Also, Complete Collection of State Trials (by Salmon, 1730 ed), vol 3, p 515.

${ }^{929}$ Today, the woman being over 16 and the act consensual, this would not be a crime. Since Lord Grey was married, he committed adultery, she fornication (she gave birth to his child).

${ }^{930}$ See The Trial of Ford Lord Grey of Werk (London, sold by J Morphew, 1716).

${ }^{931}$ See also Pierson (1738) 2 Andr 311 ((95 ER 41)(abducting a young woman (under 16), though with her consent, was punishable at common law. In this case the girl was a ward of chancery and wealthy, who married a man beneath her). This case followed Twistleton (1667) 1 Sid 387 (82 ER 1173). Cf. DPP v Shaw [1962] AC 220, pp 286-7 per Lord Tucker (no crime of abduction at the time of Delaval (1763) if over 16 and not an heiress). See also Tremaine (in 1723), n 355, p 213 (Grey's indictment which he described as 'inticing his wife's sister from her father's house and living in adultery with her').

${ }^{932}$ Adultery was a crime in the City at the time, see 80 ER 677, 686. See also H Longueville, The Curious Case of Lady Purbeck (Echo Library, 2007)(the daughter of Coke CJ, tried in 1627 for adultery with Sir Robert Howard by the Court of High Commission. He was tried in 1635 by the Star Chamber). However, the adultery was committed in Surrey in Ford's case. Further, under the general law, while adultery was a crime during the Interregnum (1642-9), it was not thereafter. Thus, adultery, per se, seems to have been passed over in the case.

${ }^{933}$ See $\mathrm{n} 930, \mathrm{p} 81$ per Pemberton CJ (to the jury) '[the information doth set forth] that my Lord Grey [married] did unlawfully solicit the lady Henrietta...to unlawful love; and that he did intice her from her father's house; and that he did cause her to be conveyed away from thence against her father's consent; and that he did unlawfully use her company afterwards in a very ill manner, an unjustifiable manner, and this, Gentlemen, is the substance of the information; in truth it is laid, that he did live in fornication with her.' Ibid, Ford was charged as per the information, $\mathrm{p}$ 94. The next term, a nolle prosequi was entered against him.

934 (1702) 2 Salk 552 (91 ER 467) per Holt CJ 'no indictment lies at common law for adultery.' See also McBain, n 66, p 37, n 192. 
Gallard

$1733^{936}$

Delaval

$1763^{937}$

Jones v Randall

$1774^{938}$

Lynn

$1788^{939}$

Crunden*

$1809^{940}$

Rouverard*

$1830^{941}$

Bunyan \& Morgan*

$1844^{942}$

Watson*

$1847^{943}$

Webb*

$1848^{944}$

Orchard*

$1848^{945}$

Mears and Chalk

$1851^{946}$

Holmes*

$1853^{947}$

Elliott \& Mary Ann White

$1861^{948}$

Farrell*
Woman running in the highway (common way), naked to the waist. Indictment contra bonos mores quashed. Nothing appeared immodest or unlawful.

Information for fraudulently assigning a female apprentice for the purpose of prostitution. Rule made absolute.

Gaming case. Dictum of Mansfield CJ.

Dis-interring a corpse for dissection. Fined 5 marks. [This case is better treated as one of unlawful treatment of the dead].

Man bathed naked at Brighton in sight of houses recently erected. Discharged on recognizance.

Indictment against a man for exposing himself to excite a servant girl in a house opposite.

Indecent exposure in a locked room in a pub. Seen through window by two persons. Convicted.

Indecent exposure in a public place (Paddington churchyard) to a single female. Insufficient publicity.

Indecent exposure in a public place (entrance to a pub), if seen by one person only, not a common nuisance.

Indecent exposure. Urinal with boxes in a public market was not a public place.

Conspiracy by false pretences to procure an infant female (15) to have sex with a man is a crime (a misdemeanour).

Indecent exposure. Man exposing himself in a bus in view of passengers. Bus held to be a public place.

Prisoners having sex in daylight on Wandsworth common in the sight of one witness only but so that any passer-by on the common (or using a public footway adjacent) could have seen them. No judgment delivered.

Indecent exposure on highway. Seen by one person only. Conviction quashed.

935 (1706) 2 Ld Raym 1197 (92 ER 291) at p 1197 'what is charged in this indictment is but solicitation of chastity, which is a spiritual offence, and not inquirable or punishable at common law.' Chastity would include virginity. Cf. Adams (1888) 16 Cox CC 544 (in a letter, he solicited the virginity of a girl aged 17 for money (£10). Sentenced to 3 days in prison for criminal libel). See also Criminal Law Amendment Act 1885, s 2 (crime to solicit a woman under 21 to have sex with another person). See also McBain, n 803 , p 486.

936 (1733) W Kel 163 (25 ER 547).

${ }^{937}$ (1763) Burr 1434 (97 ER 913) per Lord Mansfield at p 1438 'It is true that many offences of the incontinent kind fall properly under the jurisdiction of the ecclesiastical court, and are appropriated to it. But, if you except those appropriated cases, this court is the custos morum of the people and has the superintenency of offences contra bonos mores; and upon this ground, both Sir Charles Sedley and Curl, who had been guilty of offences against good manners, were prosecuted here.' See also Lord Campbell, Lives of the Chief Justices, (Murray, 1849, 2 vols), vol 2, p 425 and Shaw v DPP [1962] AC 220 per Ashworth J at p 234.

${ }^{938}$ (1774) Lofft 383 (98 ER 706) per Mansfield CJ at p 385 'Whatever is contrary, bonos mores est decorum, the principles of our law prohibit, and the king's court, and the general censor and guardian of the public manners, is bound to restrain and punish.'

${ }^{939}$ (1788) 2 TR 733 (100 ER 394) at p 734. 'The court said that common decency required that the practice should be put a stop to. That the offence was cognizable in a criminal court, as being highly indecent, and contra bonos mores; at the bare idea alone of which nature revolted. That the purpose of taking up the body for dissection did not make it less an indictable offence.' See also McBain, $\mathrm{n} 19$, p 96.

${ }^{940}$ (1809) 2 Camp 89 (170 ER 1091) per M'Donald CB at p 90 'The [D], by exposing his naked person on the occasion alluded to, was guilty of a misdemeanor... Whatever his intention might be, the necessary tendency of his conduct was to outrage decency, and to corrupt the public morals... Whatever place becomes the habitation of civilised men, there the laws of decency must be enforced.'

${ }^{941}$ Unreported case at the York Assizes referred to by Parke B in Webb who stated that he left it to the jury whether those in the street could have seen him or not (not whether they did see him) and that, if they could have seen him, it was a nuisance.

942 (1844) 1 Cox CC 74.

943 (1847) 2 Cox CC 376 per Denman CJ at p 376 'The general rule is, that a nuisance must be public; that is to the injury or offence of several. There is no precedent of such an indictment as the present and we are not inclined to make one. '

944 (1848) 1 Den 338 (169 ER 271). Followed Watson.

945 (1848) 3 Cox CC 248.

946 (1851) 2 Den 79 (169 ER 426). Delaval was cited.

${ }^{947}$ (1853) 1 Dears CC 207 (169 ER 697) per Parke B at p 209 'this omnibus was a public place.'

${ }^{948}$ (1861) Le \& Ca 103 (169 ER 1322) 


$\begin{array}{ll}\text { Thallman* } & 1863^{950} \\ \text { Howell \& Bentley } & 1864^{9} \\ \text { Harris* } & 1871^{952} \\ \text { Reed* } & 1871^{953}\end{array}$

Saunders \& Hitchcock* $\quad 1875^{94}$

Sargeant* $1875^{955}$

Clark $1883^{956}$

Wellard* $1884^{957}$

Singleton v Ellison $\quad 1895^{958}$

Berg $1927^{959}$

Dale $1960^{962}$

Shaw v DPP $1962^{963}$
Indecent exposure. Man exposing himself in view of windows of inhabited house. Held to be a public place.

Procuring a girl (aged 17) to become a prostitute.

Indecent exposure in a urinal in Hyde Park.

Nude bathing. Unlawful for men to bathe without any screen or covering so near to a footway frequented by females that exposure of their persons must necessarily occur. Those who so bathe are liable to an indictment for indecency.

Indecent pay-view exhibition in booth at Epsom Downs. Public place.

Same as Saunders (above).

Exposed dead body a child in a public highway. [This is better treated as an offence relating to unlawful treatment of the dead]

Indecent exposure before several girls in a public place.

Women occupied house frequented by men for sex. No other woman frequenting it. Not a brothel for the purposes of the Criminal Law Amendment Act 1885, s 13(1).

Brett owned a house in which he lived with female partner, Carrie. It was visited by his nephew (Lummies) and a friend (Berg). All were convicted of conspiring to corrupt public morals and to debauch persons visiting the house. Brett and Carrie were also convicted of keeping a disorderly house and Lummies of aiding and abetting. Although the case is uncertain, it seems likely they put on a (crossdressing) play and visitors engaged in (or might engage) in homosexual acts with Berg. It was unclear whether payment was made/to be made. ${ }^{960}$ Leaving aside the issue of disorderly house, the conviction was for conspiring to debauch (have sex with) visitors to the house. However, Peirson (1706)(to solicit sex) and Singleton $v$ Ellison (1895)(inviting men to the owner's house for sex) were not crimes. ${ }^{961}$

Accused convicted of a conspiracy to debauch (i.e. have sex with) such persons as should resort to a certain disorderly house.

Published ladies directory of names and addresses of prostitutes. Conspiring to corrupt public morals was a common law misdemeanour. There was evidence

${ }_{949}$ (1862) 9 Cox CC 336. Irish Court of Criminal Appeal per Monaghan J at p 448 'an exposure seen by one person only, and being capable of being seen by one person only, is not an offence at common law.'

${ }^{950}$ (1863) Le \& Ca 326 (169 ER 1416). See also 9 Cox CC 388. See also Butler (1834) 6 C \& P 368 (172 ER 1280)(incited girl to place herself indecently (in a sexual position). Held, assault (battery). The age of the girl was not given). Today, if aged over 16 and consensual, this would not be a crime.

951 (1864) F \& F 160 (176 ER 513).

952 (1871) LR 1 CCR 282.

953 (1871) 12 Cox CC 1.

954 (1875) 1 QBD 15.

955 (1875) JP 760. Coleridge CJ 'delivering the judgment of the court, said it had been proved that the prisoners kept on Epsom Downs a booth for the purpose of exhibiting an indecent and disgusting show; that they did so exhibit it; that they invited all persons within reach to come and see it, and received all who paid for so doing, and that those who went in did see an exhibition of the most loathsome kind. Those facts were abundant to constitute a common law offence...'

${ }^{956}$ (1883) 15 Cox 171.

${ }^{957}$ (1884) 14 QBD 63.

958 (1895) 1 QB 607. Per Wills J 'A brothel is the same thing as a bawdy house.'

959 (1927) 20 Cr App R 38.

${ }^{960}$ The charge of keeping a disorderly house seems mis-conceived since there was no allegation of it being open to the public generally or that payment was made for sexual services. Any cross-dressing was also irrelevant since it was not a crime. Today, homosexuality is not a crime either and for conspiring to outrage public decency, a 'public' element is required. In light of Walker (1996), this would not seem present, being a private house. See also Shaw $v$ DPP [1962] AC 220, at p 288 per Lord Tucker for commentary on the case.

${ }^{961}$ 'Debauch' generally was a synonym for 'corrupt', see OED, $\mathrm{n} 4$ (corrupt) and it was not restricted to the taking of virginity. It was also generic and, thus, it embraced adultery or fornication or (in this case) homosexual acts. Likely, therefore, 'debauch' was a later synonym for 'fornicate' in Anglo-Saxon and later times, in the ecclesiastical sense when there were only two categories: adultery and fornication, with the later being a residual category, see $\mathrm{n} 836$.

${ }^{962}$ Unreported Central Criminal Court case referred to in Shaw v DPP [1962] AC 220 at $\mathrm{p} 288$ per Lord Tucker. See also McBain, $\mathrm{n} 90, \mathrm{p}$ 41.

${ }^{963}$ [1962] AC 220. 


\begin{tabular}{|c|c|c|}
\hline Mayling* & $1963^{964}$ & $\begin{array}{l}\text { Outraging public decency in a public loo. Crime requires more than one person } \\
\text { must have been able to see it. Two did. Convicted. }\end{array}$ \\
\hline Knuller v DPP & $1973^{965}$ & Gay contact adverts in magazine. \\
\hline May & $1990^{966}$ & $\begin{array}{l}\text { Outraging public decency. Schoolmaster simulating sexual acts in front of pupils. } \\
\text { Convicted. }\end{array}$ \\
\hline Gibson \& Sylverie & $1990^{967}$ & $\begin{array}{l}\text { Exhibition of human head with freeze-dried foetus' earrings. [This is better treated } \\
\text { as one of unlawful treatment of the dead, a foetus being so included] }{ }^{968}\end{array}$ \\
\hline Lunderbech* & $1991^{969}$ & $\begin{array}{l}\text { Masturbating in a park where children present. Conviction upheld. } 2 \text { police officers } \\
\text { had seen him. }\end{array}$ \\
\hline Rowley & $1991^{970}$ & $\begin{array}{l}\text { Appellant left notes for boys in public places. Diary in his house indicated a desire } \\
\text { for sexual activity with boys. Nothing in the notes capable of outraging public } \\
\text { decency, since no deliberate commission of an indecent act. }\end{array}$ \\
\hline Walker (Steven)* & $1996^{971}$ & Indecent exposure to two young girls in his house. Not a public place. \\
\hline Choi & $1999^{972}$ & Intimate filming of woman in ladies a loo in a supermarket without consent. \\
\hline Tinsley & $2003^{973}$ & Upskirting in a supermarket. Guilty plea. Seen by others. \\
\hline Rose v DPP & $2006^{974}$ & Oral sex in a bank foyer. Later viewed on CCTV by bank employee. Insufficient. \\
\hline Hamilton & $2007^{975}$ & $\begin{array}{l}\text { Intimate filming of a woman without consent (upskirting) in a supermarket. It was } \\
\text { necessary to prove the doing of an act of such a lewd, obscene or disgusting } \\
\text { character as to outrage public decency, judged by contemporary standards. This, in a } \\
\text { place to which the public had access. Or, where what was done was capable of } \\
\text { public view in a way capable of being seen by } 2 \text { (or more) persons present. } \\
\text { It was unnecessary to prove that anyone witnessed the act or had been outraged. }{ }^{976}\end{array}$ \\
\hline $\mathrm{F}$ & $2010^{977}$ & $\begin{array}{l}\text { Man masturbating in a car in a street near a field on which young boys were playing } \\
\text { football. Public element not satisfied on the facts. }\end{array}$ \\
\hline
\end{tabular}

Notes:

Cases from 1663-2010 on public indecency comprised the following which are either no longer a crime (viz. (a) and (d)) or better dealt with under the law of burial or prostitution (viz. (b) and (c)).

(a) Adultery, Fornication, Soliciting Chastity. The courts confirmed it was not a crime to commit adultery (in 1702) or fornication (Singleton v Ellison in 1895) or to solicit the chastity (inc. virginity) of a person (in 1706) - the position today;

(b) Dis-interring Corpse/Exposing Dead Body on Highway. The cases were Lynn (1788) and Clark (1883). These, today, are better treated as unlawful treatment of the dead and should be in burial legislation. So too Gibson \& Sylverie (human head with foetus earrings, 1990);

\footnotetext{
964 [1963] 2 QB 717.

965 [1973] AC 435.

966 (1990) 91 Cr App R 157.

${ }^{967}$ [1990] 2 QB 619.

${ }^{968}$ See McBain, n 19, p 97.

${ }^{969}$ [1991] Crim LR 784. See also Cheeseman v Carr [1991] Crim LR 296. See also Ketteridge [2015] 1 Cr App R (masturbated in a car while driving alongside a school minibus with pupils. Also, when schoolgirls were by the side of the road). See Archbold Procedure, n 62, para $14-263$.

${ }^{970}$ [1991] 1 WLR 1020 per Taylor J at pp 1023-4 'the offence of public indecency consists in the deliberate commission of an act which is per se of a lewd, obscene or disgusting nature and outraging public decency.'

${ }^{971}$ [1996] 1 Cr App R 111.

972 [1999] EWCA Crim 1279, [1999] 8 Archbold News 3.

${ }^{973}$ [2003] EWCA Crim 3032 (appeal against sentence after guilty plea).

${ }^{974}$ [2006] 1 WLR 2626.

${ }^{975}$ [2008] QB 224.

${ }^{976}$ The latter sentence would seem wholly correct in that, as can be seen from early indictments (Chitty, 1826, see ns $562 \& 567$ ), nuisance (annoyance) did not have to be pleaded for public indecency offences.

977 (2010) 174 JP 582.
} 
(c) Prostitution. Cases such as Delaval (1763) (fraudulently assigning female apprentice for prostitution), Mears and Chalk (1851) (conspiring by false pretences to procure a girl to become a prostitute) and Howell \& Bentley (1864) (procuring a girl to become a prostitute) - are better dealt with under the law of prostitution;

(d) Directory/Contacts. Publishing a directory of prostitutes (Shaw v DPP, 1962) or gay contact adverts (Knuller v DPP, 1973).

Cases from 1663-2010 on public indecency also covered:

(e) Indecent Exposure. This comprises the large majority of the caselaw. The majority was sexual viz: (i) man exposing himself (including masturbation); (ii) persons having sex - Elliott \& White (1851); (iii) simulating sexual acts - May (1990) ; (iv) oral sex - Rose v DPP (2006)( albeit insufficient publicity on facts). Also, non-sexual - being nude bathing, see Crunden (1809) and Reed $(1871)$;

(f) Intimate Filming. These comprise up-skirting, see Choi (1999), Tinsley (2003) and Hamilton (2007);

(g) Pav-View. Cases comprise Saunders (1875) and Sargeant (1875). These would be better treated as a separate offence today, by being treated as a form of sex establishment, see Local Government (Miscellaneous Provisions) Act 1982 (Control of Sex Establishments). ${ }^{978}$

\section{Copyrights}

Copyright for this article is retained by the author(s), with first publication rights granted to the journal.

This is an open-access article distributed under the terms and conditions of the Creative Commons Attribution license (http://creativecommons.org/licenses/by/4.0/).

${ }^{978}$ See also McBain, n 90, p 50. 